\title{
A nevelésszociológia alapjai
}

haték0ninuiuiós g

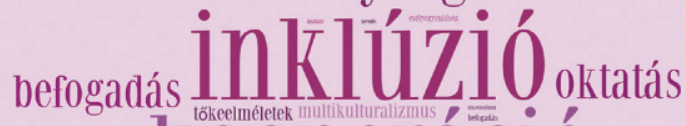

K00peráció

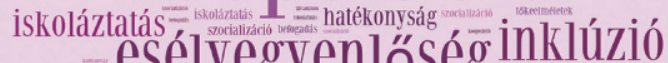
- esélyegyenlőséḡ inklúzió iskoláztatás urasua

multikulturalizmus inkinio mobilitás OK d L S mobilitís -ializáció

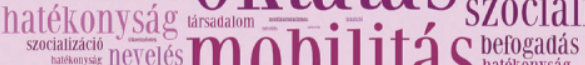

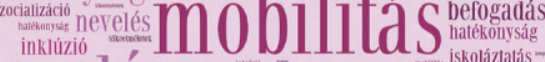

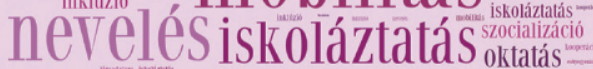

esélȳegyenlőség multikulturalizmus kooperáció

=- = tőkeelmélētēk mobilitas tökieelméletét K00peráció

társàdàlom esélyegyenlöség ПeVelés befogadás

multikulturāliżmus 
A NEVELÉSSZOCIOLÓGIA ALAPJAI 



\section{A NEVELÉSSZOCIOLÓGIA ALAPJAI}

Pécsi Tudományegyetem Bölcsészettudományi Kar Neveléstudományi Intézet

Romológia és Nevelésszociológia Tanszék

Wlislocki Henrik Szakkollégium

Pécs, 2015 
A TÁMOP-4.1.2.B.2-13/1-2013-0014 Pedagógusképzést segítő hálózatok továbbfejlesztése a Dél-Dunántúl régióban pályázat támogatásával készült a tananyag digitális átdolgozása.

KÉSZÜLT A TÁMOP-4.1.1.D-12/2/KONV-2012-0009

KOMPLEX HALLGATÓI SZOLGÁLTATÁSOK FEJLESZTÉSE

HÁTRÁNYOS HELYZETÛ HALLGATÓK RÉSZÉRE

A WLISLOCKI HENRIK SZAKKOLLÉGIUM SZERVEZÉSÉBEN CÍMUU PROJEKT TÁMOGATÁSÁVAL

Lektorálta: Forray R. Katalin

Szerkesztette: Varga Aranka

Olvasószerkesztő: Szerencsés Hajnalka

Nyomdai előkészítés: Kiss Tibor Noé

A kötet digitalizálását végezte Ambrus Attila József

ISBN (pdf) 978-963-642-853-2 - DOI 10.15170/BTK.2015.00004

ISBN (print) 978-963-642-805-1

Az elektronikus könyv további formátumokban is elérhető:

ISBN (epub) 978-963-642-850-1 - DOI 10.15170/BTK.2015.00001

ISBN (mobi) 978-963-642-851-8 - DOI 10.15170/BTK.2015.00002

ISBN (html) 978-963-642-852-5 - DOI 10.15170/BTK.2015.00003

(C) Pécsi Tudományegyetem, Szerzők, Varga Aranka szerkesztő, 2015

Készült a Bolko-Print nyomdájában

(7623 Pécs, Rét u. 47., ügyvezető: Szabó Péter)

Kiadja a Pécsi Tudományegyetem Bölcsészettudományi Kar

Neveléstudományi Intézet Romológia és Nevelésszociológia Tanszék, Wlislocki Henrik Szakkollégium

Cím: 7624 Pécs, Ifjúság útja 6.

Felelős kiadó: Orsós Anna

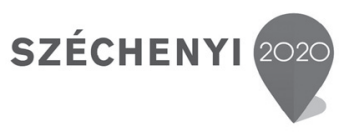




\section{Tartalom}

Forray R. Katalin: Bevezetés $\quad 7$

Meleg Csilla: Nevelésszociológiai problémakörök és nézőpontok 19

Bigazzi Sára: Tudás és kontextus: a szociális reprezentáció elmélete $\quad 49$

Kozma Tamás: Az oktatási rendszer szociológiája 79

Boreczky Ágnes: Családkutatások nevelésszociológiai nézőpontból 103

Pusztai Gabriella: Tókeelméletek az oktatáskutatásban 137

Torgyik Judit: Multikulturalizmus, interkulturális nevelés 161

Fehérvári Anikó: Társadalmi mobilitás és az iskola 183

V. Gönczi Ibolya: A gyermekvédelem és az iskola 211

Varga Aranka: Esélyegyenlőség és inklúzió az iskolában 241

Huszár Ágnes: A nyelvi szocializáció és az iskola 273

Lannert Judit: Hatékonyság, eredményesség és

méltányosság a közoktatásban 295 



\section{FORRAY R. KATALIN}

\section{Bevezetés}

A nevelésszociológia „az a szakszociológia, amely a különböző társadalmi közösségeket szocializáció közben mint a nevelés alanyait, illetve tárgyait vizsgálja. A nevelésszociológia fogalmának meghatározására - sem tárgyát, sem feladatait illetően - nem alakult ki egységes vélemény. Ezért nevelésszociológiáról - vagy az egyes részletkérdéseiről - szóló feldolgozásokban a legkülönfélébb értelmezési lehetőségek fordulnak elő" Kozma Tamás, az első magyar nyelvű nevelésszociológiai kötet szerzője ekként mutatja be a tudományterületet az MTA Pedagógiai Bizottság Nevelésszociológiai Albizottság alakuló ülésén. A több kiadást megért kötet máig megalapozza azokat a tanulmányokat, amelyek a nevelés és oktatás intézményeit és folyamatait a nevelésszociológia szemléletével közelítik meg.

Kötetünk tanulmányai jól példázzák e megközelítési és elemzési mód sokféleségét, egyúttal szemléletének meghatározó vonásait. A tudományterület kiemelkedő múvelőinek írásai alapos áttekintést nyújtanak a nevelésszociológia történetéről, kapcsolódásáról a neveléstudományhoz és a szociológiához, és azokról a jelenleg is izgalmas kérdésekről, amelyek a politika formálását és eredményességét érintik.

A kötet bevezető tanulmánya - Meleg Csilla professzor írása - a személetmód történeti és interdiszciplináris aspektusait tekinti át és elemzi. A tanulmány széles körű szakirodalmi áttekintése és a szakirodalomnak a nevelésszociológia kérdéseinez való kapcsolása olyan izgalmas ismeretekkel gazdagítja e terület tanulmányozását, amelyek másutt nem lelhetők fel.

Bigazzi Sára a szociális reprezentáció kérdéseit, az e területre irányuló kutatás eredményeit tekinti át. A pszichológiai nézőpont jól érzékelhetően tágítja és gazdagítja a nevelésszociológiai kérdések tanulmányozását. 
Kozma Tamás az oktatási rendszer egészét elemzi a nevelésszociológia szempontjából. A tanulmány fő része két oktatási rendszert hasonlít össze, a kontinentálist és az atlantit. Ezután a nevelésszociológia szempontjából értelmezi a főbb jellemzőket.

Boreczky Ágnes a családkutatás kérdéseit és az erre irányuló kutatások főbb eredményeit elemzi. A család fogalmát széles történeti és szociológiai összefüggésekbe helyezve mutatja be a nevelés eredményeit, kutatható problémáit.

Pusztai Gabriella tanulmánya jó példája annak, hogyan lehet gazdag szakirodalmi háttértanulmányok alapján a bölcsészhallgatók többségétől talán idegen tematikát bemutatni és értelmezni.

Torgyik Judit alapos elemzéssel mutatja be a multikulturalizmus-interkulturalizmus nemzetközi és hazai irodalmát. Jól követhetők a kutatási kérdések és az oktatáspolitikai reakciók módosulásai az elmúlt évek változó politikai viszonyai nyomán.

Fehérvári Anikó tanulmánya hasznos és jól értelmezhető áttekintést nyújt azokról a kutatásokról, amelyek az iskolai eredményesség és a társadalmi mobilitás összefüggéseire irányulnak. A tanulmány kitér az Arany János Program elemzésére, amely éppen az összefüggésekből eredő tanulmányi eredményesség javítására irányul.

V. Gönczi Ibolya tanulmánya továbbvezeti az olvasót az iskola világából a gyermekvédelem felé. A tanulmány az iskola és a gyernmekvédelem múködésének jogszabályi összefüggéseit mutatja be. Különösen érdekes a jelen helyzet tárgyalása, azoknak a pontoknak kiemelt megvitatása, amelyek a szakértő szerző szerint vitathatónak látszanak.

Varga Aranka tanulmánya kapcsolódik ehhez, hiszen az esélyegyenlőség kérdéseit a reziliencia és az inklúzió szempontjából tárgyalja. Olyan elméleti nézőpontokat kínál, amelyek újdonságnak számítanak nemcsak a hazai, hanem a nemzetközi kutatásban is. Az elméleti kérdéseket gazdag empirikus tapasztalatokkal támasztja alá.

Huszár Ágnes tanulmánya a nyelvelsajátítás pszichológiai és szociálpszichológiai összefüggéseit mutatja be, kiemelve a legfontosabb elemeket. Ennek a nevelésszociológiai szem- 
pontból is fontos kérdéskörnek a legjellemzőbb problémáit mutatja be.

Lannert Judit tanulmánya a jelen oktatásügyének egyik kiemelkedően fontos eseményét, a PISA-vizsgálat következtetéseit elemzi és állítja összefüggésrendszerbe.

$\mathrm{Az}$ alábbiakban mindezeket egy további nézőponttal, egy olyan szemléleti módszerrel szeretném gazdagítani, amely további lehetőséget ad a nevelésszociológiai kutatások alkalmazhatóságának.

\section{A szocializációs környezet}

Az egyéni különbségeket rendszerint két tényezőcsoportra szokták visszavezetni: az örökölt feltételek különbségeire és a környezet hatásaira bekövetkező különbségekre. A két tényezőcsoport egymáshoz viszonyított arányának különösen nagy gyakorlati jelentősége van, mert a nevelés csak akkor ígér sikert, ha elutasítja az örökletes tényezők meghatározó voltát. Az öröklés és környezet dilemmáról a tudományos kutatás nem tudott döntő bizonyítékkal szolgálni, ma ebben a kiélezett formában már nem is fogalmazódik meg. Sokkal inkább arról van szó, hogyan viszonyulnak egymáshoz az öröklés (genetika) és a környezeti hatások.

A környezet tanulmányozása a modern pedagógiában a pszichológiai kutatásokhoz kapcsolódik, amely viszont ezen a területen a biológiai tudományokból vett át eredményeket. Boross és Pléh (2004) széles szakirodalom alapján részletesen elemezve az évszázados kérdést, arra figyelmeztetnek, hogy csak egyes részletekre tudunk magyarázatot adni, nem helyes a kérdést vagylagosan feltenni.

Lewin (magyarul 1975) alaklélektanra alapozott környezetfelfogása abból indul ki, hogy a nem pszichológiai alapok általában azt a célt szolgálják, hogy az egyén vagy csoport életének keretfeltételeit, „,mozgásterét” megismerjük. Az adott környezet - egyéni és átlagos környezetet különböztet meg, s az utóbbit a szociológiai vizsgálódás területére utasítja - a gyermek viselkedésének minden területét befolyásolja. Az egyéni környezet sajátos kvázifizikai, kváziszociális, kvázimentális kör- 
nyezet, amit „pszichológiai” környezetnek nevez. A környezeti hatások és az egyén dinamikus viszonyában olyan circulus vitiosusok alakulhatnak ki, amelyek következtében az intelligens gyerekek teljesítményei tovább nőnek, a kevésbé intelligenseké csökkennek.

Az amerikai eredetű mikrotársadalmi környezetfelfogással szemben német nyelvterületen fejlődött ki a Milieukunde, egy sajátos, a közvetlen környezetre irányuló kutatási irányzat. Legjelentősebb képviselője, Adolf Busemann (1927) a pedagógiai pszichológiához kapcsolódik empirikus kutatásokkal és antropológiai magyarázatokkal. A mikrokörnyezet - mindenekelőtt a család problémáinak tanulmányozása - alapján pedagógiai miliőtipológiát dolgozott ki. A pedagógia feladatát abban látta, hogy segítsen az egyénnek kiszabadulni környezetének nyomasztó hatása alól.

A szociálpedagógia eredete a 20. század elejére nyúlik viszsza. Ez a hangsúlyt a szocializációs folyamatra helyezi, s a befolyásolásban nagy jelentőséget tulajdonít a prevenciónak. Ezért érdeklődési területe újabban az iskolán kívüli, az iskola előtti, az intézeti nevelés és múvelődés vizsgálatára terjed ki.

A pedagógia környezeti feltételekre irányuló figyelmének fokozódását világszerte jelzi a nagyszámú integráló program, amelyek jelentős része a környezeti feltételek hatásainak kiegyenlítésére irányul.

\section{A környezet vizsgálatának lehetőségei}

A pszichológiai modellekben a környezet úgy jelenik meg, mint az egyén környezete, azaz úgy, hogy minden egyes egyén saját környezetében vizsgálható. Egy gyermek a családjában él, a család meghatározott anyagi és kulturális viszonyokkal jellemezhető, saját helye van a testvérsorban, pozíciója a kortárs csoportban, az iskolai osztályban. E logikának megfelelően, ha társadalmi együtteseket vizsgálunk, akkor is egyénekből indulunk ki, de olyan környezetet feltételezünk, amelyet el lehet hagyni, amely változatlan marad akkor is, ha az egyén elhagyja, mert saját törvényei szabályozzák. Ez a környezet lehet a szűkebben vagy tágabban értelmezett lakóhely. 
Az ilyen hipotézisekre alapozó kutatásokban a lakóhely (település, megye) esetenként megjelenik ugyan, de rendszerint nem úgy, mint objektív környezeti adottság, amely az egyéntől független paraméterekkel jellemezhető, hanem mint - éppen úgy, ahogy a család - egyéni, „szubjektív” környezeti feltétel.

$\mathrm{Ha}$ az egyének, csoportok viselkedését úgy vizsgáljuk, mint amelynek térbeli és időbeli kapcsolatai a környezet szelektív, disztributív és adaptív hatásain keresztül valósulnak meg, akkor a környezetet nemcsak többtényezősnek, hanem többszintűnek is látjuk. Így „meghosszabbítjuk” a közvetlen környezetet a nagyobb földrajzi, kulturális, társadalmi összefüggésrendszerek irányába. Ezt nevezzük térnek, és a vizsgálat módját szociálökológiainak.

A szociálökológiai elemzésben az kap hangsúlyt, hogy a társadalmi tevékenységek mindig valamilyen térben is elhelyezkedő környezetben folynak. Amikor ezeket elemezzük, a környezet elemeinek térbeli elrendeződéséből adódó kölcsönhatásait is értelmezni lehet.

Az ökológiai szemléletű kutatás az egyéni adatokat nem a „vertikális” társadalmi struktúrába, hanem a „horizontális" szerkezetbe csatlakoztatja. Érzékletessé válik az ökológiai elemzésnek az a sajátossága is, hogy az elemzés nemcsak egyének szintjén, hanem további szinteken is folyik. Kimunkálását az tette lehetővé, hogy a számítógépes módszerek elterjedésével kialakultak a többtényezős matematikai-statisztikai elemzési módszerek. Ez persze nem jelenti azt, hogy ökológiai szemléletű kutatást nem lehet bonyolult számítógépes eljárások nélkül lebonyolítani, de tény, hogy az összetettebb elemzések elvégzését gyorsítják.

Az ökológia fogalmát többféle értelemben használják. Tágan értelmezve az ember-környezet viszonyrendszer egészét, szűkebb értelmezésben az embert körülvevő tárgyi világot (a lakóhelyet, a település ökológiai adatait) értik rajta. Használják egyszerűen „ökológia” formában, mondják humán ökológiának és szociálökológiának. A fogalomnak ez a többféle formája összefügg keletkezésének és elterjedésének történetével. 


\section{Ökológiai szemlélet a szocializáció kutatásában}

Az ökológia fogalma a görög „oikos” (ház) szóból vezethető le. $\mathrm{Az}$ „oikos" a lakóházat, a benne és körülötte szerveződő háztartást és ennek természetes és múvi környezetét jelenti. Ahogyan a háztartás szerveződik, amilyen kapcsolatokat kialakít tárgyi és szociális környezetével, mind befolyásolja a gyermek nevelését.

Az ökológia fogalma a 19. századi biológiai evolucionizmusból került át a társadalomtudományba. A városszociológia a biológiaival adekvát társadalmi környezetnek a város, a városrész természeti, szociális és múszaki adottságait tekintette. Érdeklődése elsősorban ezek térbeli elhelyezkedésére, valamint a társadalmi csoportok mozgására irányult. A múlt század harmincas éveiben visszaszorult ez a hipotézis, sokan azt is kétségbe vonták, van-e tényleges jelentősége a lakóhelynek az ember fejlődése, életmódja szempontjából. A hetvenes években kapott új lendületet az ökológiai szemléletű kutatás. A múlt század húszas-harmincas éveiben virágzásnak indult Chicago-iskola városszociológiai kutatásai vitték át a fogalmat a társadalomtudományokba, „human ecology"-ként különböztetve meg eredeti formájától (Szelényi, 1973).

Hagyományai vannak a búnözés, általában a deviáns magatartás tanulmányozásában, Durkheim öngyilkosság-vizsgálata óta számos szociálökológiai elemzés született ebben a témakörben. E nézőpont alkalmazását az teszi szükségessé, hogy világossá vált: a deviáns magatartások terjedésében a lakóhelyi környezetnek nagy hatása van.

Az ökológiai szocializációkutatás legnagyobb hatású szakembere, Brofenbrenner (1978) számolt be arról a folyamatról, hogy jut el a pedagógiai érdeklődésű szociálpszichológia a szociálökológiai szemléletmód szükségességének felismeréséhez. Európa, Észak-Amerika, Ázsia számos országában (köztük a volt Szovjetunióban) végeztek összehasonlító kutatásokat a gyermeknevelésről. Azt tapasztalták, hogy a különböző kultúrákban felnövekvő gyermekek a magatartás némely területén olyan mértékben különböznek egymástól, hogy ezekből a magatartásokból következtetni lehet az országra, amelyből származnak. Bár ez a tapasztalat elméleti szinten azt a felté- 
telezést sugallja, hogy a gyermekek gyakorlatilag korlátlanul formálhatók, a kompenzáló programok mégsem váltották be a hozzájuk füzött reményeket (vö. Kozma, 1975). Olyannyira nem, hogy Bronfenbrenner már azt is hajlamos kétségbe vonni, hogy a szocializáció befolyásolásában egyáltalán történt-e valami. Ezért volt szükség arra, hogy újra elemezzék az elméleti modelleket, stratégiákat, egyáltalán a kettő kapcsolatát.

A kérdések a mindennapi élet gyakorlatából jönnek: mit tudnak a szülők a gyermeknevelésről; kihez fordulhatnak tanácsért, ha problémáik vannak; hogyan érzékelik a szülők gyermekeik fejlődését; milyen jövőperspektíváik vannak stb. Valójában a kérdések arra irányulnak, hogy megtudjuk, mi a gyermek helye egy adott társadalomban, a szociálpolitikában, az oktatáspolitikában.

Bronfenbrenner az egyéntől induló táguló körökben értelmezi a környezetet. Az egyént körülvevő szúkebb környezet (lakás, iskola, utca stb.) térbeli elrendeződése, anyagi ellátottsága, a különböző szerepet vállaló személyeknek az egyénhez fűződő kapcsolatai, tevékenységei jelentik az első szintet. A második szint az elsőt körülvevő tágabb környezet, amely áthatja és formálja a szúkebb környezetet is. Ezen a szinten szerepe van a szociális hálózatnak, azoknak az informális társadalmi struktúráknak, amelyeket az ott élő emberek kialakítanak (kortárs csoportok, szomszédság stb.). Erre a szintre sorolhatók az intézményi rendszerek. Némelyek közülük közvetlenül felelősök a gyermekek és gondozóik jólétéért (oktatási, egészségügyi, szociálpolitikai intézmények), mások hatása közvetett ugyan, de felelősek azért, hogyan tölti az életét (jogi, közigazgatási rendszer, tömegkommunikáció, gazdaság stb.). A harmadik szintet az ideológia képezi, amely átfogja és áthatja az előző kettőt. Ez határozza meg, mi a gyermek, a serdülő, a fiatal helye a társadalom egészében, milyen értéket tulajdonít a társadalom a gyermek- és ifjúkornak. Ezt a struktúrát fejleszti tovább: kiindulva a mikrorendszerből, amely speciális helyzeteket, miliőket („,setting”) tartalmaz, a mezo- és exorendszeren át terjeszti ki a környezet fogalmát a makrorendszerig, a kultúrában vagy szubkultúrában létező általános prototípusok rendszeréig.

A szociálökológiai szemléletű szocializációkutatás kiemelkedő területe a kultúraközi összehasonlítás. A „cross-cultural 
studies" rendkívül népszerű és izgalmas empirikus kutatási irány, amely a különböző kultúrákat hasonlítja össze képviselőik magatartásmódja, szokásai szempontjából. Az egyik leghíresebb ilyen kutatás - a setting elmélet klasszikussá vált példája - egy angol és egy amerikai kisvárosban élő fiatalok nevelődését hasonlítja össze 220-230 „setting-genotípus” alapján, amelyek a kutatók felfogása szerint magatartásukat formálják (Barker és Schoggen, 1973).

Bronfenbrenner elméleti modellkísérletei, Barker és Schoggen empirikus kutatása egyaránt érzékeltetik az ökológiai szemléletű kutatás egyik alapvető problémáját: olyan összetett megközelítésről van szó, amely egyetlen empirikusan vizsgálható egységben kívánja leírni az egyénre ható természeti, társadalmi környezet teljességét, amelyet ráadásul egyénenként és csoportonként is eltérőnek feltételez. Sajnos Bronfenbrenner modellje nehezen operacionalizálható, Barker és Schoggen változóinak jegyzéke kisebb kötetet tölt ki, és együtt sem bizonyítják a ráfordításból eredő hasznot. Kevésbé látványosak, de egyelőre jobban bizonyítottak azok az ökológiai szemléletű kutatások, amelyek a környezeti tényezőknek csak egy-egy csoportját választják ki elemzésre.

\section{Területi elemzés}

A tanulási folyamatok eredményességének társadalmi összefüggéseivel kapcsolatban számos alapvető kérdés fogalmazható meg. Így feltehető a kérdés, milyen szociális és ökológiai faktorok függenek össze a gyermekek fejlődési és tanulási feltételeivel; milyen népességcsoportokban vagy rétegekben, milyen szociokulturális környezetben alakíthatók ki a fejlődési és tanulási feltételek empirikusan elkülöníthető szindrómái; hogyan hozhatók be az indulási feltételek szociokulturális megalapozottságú különbségei a tanulási pályafutás során.

A lakóhelyi szociális környezetre irányuló kutatásokon belül két irányzat különíthető el. Az egyik empirikus módszerekkel tanulmányozza egy-egy terület szociális miliőjét (város- és településszociológia). A másik lakóhelyi aggregátumokból indul ki (pl. városnegyedek, falvak, régiók), és a hivatalos állami sta- 
tisztikákból képez indikátorokat a népesség szerkezetének, az épített környezet jellegének, infrastrukturális ellátottságának megragadására. Az előbbi irány társadalmi szerveződéseket tár fel egy lakóhelyi településen, az utóbbi lényegében kész, „allokált" társadalmi egységből indul ki, amelyekről feltételezi, hogy a vizsgált kérdések szempontjából relevánsnak tekinthetők.

A múlt század hatvanas-hetvenes éveiben a társadalmi jelzőszámok kimunkálása, a környezeti taxonómiák létrehozása voltak ennek az érdeklődési területnek a reprezentatív eredményei (Andorka, 1975). Ezek a munkák - mint minden, a komplexitás igényével fellépő konstrukció - váltottak ki kritikát: vitatták, mennyiben írható le a társadalom statisztikai indexekkel. Az irányzat vitán felül kiemelkedő eredménye, hogy kimunkálta az állami statisztikák társadalomtudományos tartalmait.

Az ökológiai kutatásban alapvető kérdés, hogy mi a régió (vagy más területi egység), az ott szerveződő lokális társadalom. Egy meghatározás szerint a régió a közös sorsú csoportokat jelenti, amelyeket területileg pontosan el lehet határolni más csoportoktól. Bourdieu (1985) a régió meghatározásában a „habitusokat” formáló történelem, a közös sors hatására helyezi a hangsúlyt. Az oktatás-nevelés szempontjából olyan környezeti részrendszerek, ahol bizonyos faktorok összessége adja a szocializáció jellegét (Forray és Kozma, 1992).

Minden területi szemléletű kutatásban alapvető kérdést jelent a megfelelő területi egységek lehatárolása. Ezek a területek ugyanis soha nincsenek egyértelműen elkülönítve, átfedések vannak, más területek hatásai érvényesülnek. A nehézségek akkor mutatkoznak meg, mikor a kutató az egyes területek közötti eltéréseket kívánja feltárni, s az adatbázis megteremtésével már kikerülhetetlenül meghatározza a vizsgálni kívánt terület nagyságát, kiterjedését, határait. Az ilyen jellegű definíciós problémák az állami statisztika adatstruktúrájának felhasználásával, azaz a közigazgatási vagy egyéb nyilvántartott „hatósági” határok (falu, város, kerület, iskolázási körzet, népszámlálási körzet stb.), valamint ezek aggregált formáival hidalhatóak át.

Rendszerint annál jobb az elemzés, minél kisebb az alapul választott területi egység, ennek viszont határt szab a népszámlálási adatok struktúrája. Például egy városi kerület egyes oktatási intézmények vonzási körzeteként túlságosan nagy le- 
het (például óvoda), más oktatási intézménytípus szempontjából túlságosan kicsi.

A népszámlálási statisztikákból építkező szociálökológiai kutatás eredménye területi tipológiák létrehozása lehet. E tipológiák önmagukban is lehetnek tudományos kutatás, összehasonlítás tárgyai, másrészt alapul szolgálhatnak más kutatásokhoz. Előnyük, hogy egy kisebb területen végzett empirikus kutatás eredményei érvényesnek tekinthetők az e típushoz tartozó több területi egységre is.

A tipológia kidolgozása során több fontos tényezőről kell dönteni. Ezek közül az egyik legfontosabb a megoszlási érték problémája. Ez azt jelenti, mit nevezzünk például „munkáskerületnek”, azaz hány százalékot kell elérnie a munkások arányának ehhez a besoroláshoz. A népesség milyen iskolázottsági összetételénél beszélhetünk „alacsony iskolázottságról”? Mi a „fejlettség”? Ezek a kérdések rendszerint az összehasonlítás során dőlnek el, a besorolás (elnevezés) csak viszonylagos lehet. Alapkérdés az is, milyen változókat választ ki a kutató, illetve hogyan rendezi a szociálökológiai változókat.

A gyakorlathoz a más társadalomtudományoknál erősebben kapcsolódó neveléstudomány mindeddig nem foglalkozott eleget a területi-társadalmi meghatározottság kérdéseivel, jóllehet a mindennapi tapasztalat is mutatja, másfajta gondolkodást kívánnak a gyerekek, fiatalok például a budapesti agglomeráció községeiben, mint a borsodi falvakban.

\section{Lehetőségek és problémák}

Az ilyen típusú kutatás arra tesz kísérletet, hogy az ember-környezet viszonyt minél sokoldalúbban ragadja meg. A hagyományosabb, mintavételen alapuló empirikus kutatás egyéni adatok elemzésére alapoz, feltételezve, hogy minden egyénnek saját környezete van. A szociálökológiai kutatás környezetfogalma többszintű: az egyéni környezet mellett „objektív” környezetet is feltételez, olyan környezetet, amelyet az egyén másokkal oszt meg. Ez a szemlélet ezért minden olyan kutatási területen haszonnal alkalmazható, ahol a hipotézis a környezeti elemek egymásra hatásának is jelentőséget tulajdonít. 
A környezet térbeli elemei, ezek elrendeződése sokszor konkrét, érzékletes. Ezzel van összefüggésben, hogy a szociálökológiai kutatás szorosan kapcsolódik a fejlesztéshez. Legfontosabb funkciójának az látszik, hogy vállalkozik, alkalmas is a híd szerepére: következetesen múvelve hidat jelenthet a neveléstudomány, a pszichológia, a szociológia, a szociálpolitika között, a tudomány és a szervezés között - lokálisan és regionálisan.

A „híd szerepből” következik egyik jelentős problémája is, az a kérdés, hogy az eredménynek ki a címzettje. Ha például azt tapasztaljuk, hogy egy iskola nehezen tud elegendő tanulót beiskolázni, akkor az melyik intézménynek, igazgatási szintnek az ügye? Elképzelhető, hogy más programot kellene ott hirdetni, kvalifikáltabb pedagógusokra lenne szükség, de elképzelhető az is, hogy a közlekedési viszonyokat kellene javítani vagy ipari bázist elhelyezni a környéken. Ezért az ökológiai szemléletű kutatás sajátos gondja, hogy gyakran tudományos kompetenciáján, ágazati hovatartozásán kívül eső eredményeket, fejlesztési javaslatokat fogalmaz meg.

\section{Zárszó}

Kötetünk tanulmányai a nevelésszociológia széles körét fogják át. A tudományág történetétől a jelen rendszerszintű és kisebb csoportokat érintő problémáinak feltárásáig elemzik az oktatás és nevelés folyamatát, ennek a folyamatnak az intézményeit, ágenseit. Mindezt azzal a szaktudással és szándékkal, hogy a ma felsőoktatásban tanulók, az oktatás gyakorlati problémáival később hivatásszerűen foglalkozók alapos ismereteket kapjanak ezekről a kérdésekről.

\section{Irodalomjegyzék}

Andorka Rudolf (1975): Társadalmi jelzőszámok-társadalomstatisztikai rendszerek. KSH, Budapest.

Barker, R. G. és Schoggen, R. (1973): Qualities of Community Life. Jossey-Bass Publishers, San Francisco-WashingtonLondon. 
Boross Ottilia és Pléh Csaba (2004): Bevezetés a pszichológiába. Osiris Kiadó, Budapest.

Bourdieu, P. (1985): Sozialer Raum und Klessen. Lecon sur la lecon. Zwei Vorlesungen. Suhrkamp, Frankfurt/M.

Bronfenbrenner, U. (1978): Ansatze zu einer Experimentellen Ökologie menschlicher Entwicklung. In: Oerten, R. (szerk.) Entwicklung als lebenslanger Prozess. Hoffmann und Campe, Hamburg.

Busemann, A. (1927): Pädagogische Milieukunde. I. Einführung in die Allgemeine Milieukunde und in die Pädagogische Milieutypologie. Halle, Saale, Schroedel.

Forray R. Katalin és Kozma Tamás (1992): Társadalmi tér és oktatási rendszer. Akadémiai Kiadó, Budapest.

Kozma Tamás (1975): Hátrányos helyzet. Tankönyvkiadó, Budapest.

Kozma Tamás (2001): Bevezetés a nevelésszociológiába. Tankönyvkiadó, Budapest (4. kiadás)

Lewin, K. (1975): Csoportdinamika. Közgazdasági és Jogi Kiadó, Budapest.

Szelényi Iván (1973): Városszociológia. Közgazdasági és Jogi Kiadó, Budapest. 


\section{MELEG CSILLA}

\section{Nevelésszociológiai problémakörök és nézőpontok}

A neveléssel-oktatással és tágabb értelemben az iskoláztatással kapcsolatos kérdések társadalmi kontextusa állandó készenlétet, a hagyományos és az újonnan felmerülő jelenségekre új és más válaszokat igényel. A nevelésszociológia éppen ennek az inter-, majd multidiszciplinaritást igénylő szemléletmódnak köszönheti létjogosultságát. ${ }^{1}$

Neveléstudomány és szociológia egymásra reflektálását, a társadalmi-gazdasági-kulturális környezetbe ágyazott elemzések szükségességét iskolai történések, megválaszolatlan kérdések és sokasodó pedagógiai problémák indokolják. Mivel minden társadalom és iskolarendszere a tudományos kutatás, az elemzés és az értékelés vonatkozásában is összekapcsolódik, az intézményes nevelést, a közoktatást sem lehet csupán didaktikai, individuális problémákra szúkíteni. A társadalomban domináló értékhierarchiák ugyanis (az iskolán keresztüli közvetítéssel) generációk szemléletét befolyásolják, alakítják vagy éppen meghatározzák. Az iskola és az iskoláztatás társadalmi kontextusban történő értelmezése nem csak a rendszerbe szerveződés felismeréséhez, hanem új értelmezési keretek kialakításához, új kérdésfeltevésekhez és ennek következtében korábbi tudásunkat bővítő új válaszok megtalálásához is hozzájárul.

\section{A nevelésszociológia témaköreinek kialakulása: társadalmi-történeti kontextus}

Témánk vonatkozásában a polgárosodás következtében gyökeresen átalakuló európai társadalmak jelentik a kiinduló- 
pontot. Történelmileg a jogegyenlőség eszméje és gyakorlata az első olyan reflexió, mely megkísérelte a privilégiumokból adódó egyenlőtlenségek általános érvényességének felszámolását. A társadalmi struktúra alakításában a meglévő hierarchiák, a korábban érvényes hagyományok és származás helyett a versenyszituációban kikristályosodó egyéni teljesítményeknek adott szerepet. Ezen elv megvalósulásához az iskola jelentette az intézményes garanciát, ahol az egyéni teljesítményeket a tanulmányi eredmények tették mérhetővé és társadalmi szinten is értelmezhetővé. ${ }^{2}$ A 19-20. század fordulójára - történelmi időben mérve - gyorsan kiépülő iskolarendszerek alkalmassá váltak annak a hitnek a megtestesítésére, hogy a felnövekvő generációk különböző startvonalról indulása korrigálható, egyenlő vagy legalábbis kevésbé egyenlőtlen életesélyekké transzformálható. ${ }^{3}$ E szemléletmód - szemben a származás szerinti hierarchiával - az érdem szerinti (meritokratikus) egyenlötlenségeknek adott társadalmi relevanciát. Ennek értelmében az iskola az egyenlő esélyek feltételeit teremti meg a tudás, a tulajdon és a munka megszerzésére, a társadalmilag előnyös pozíciókba kerülésre. A meritokratikus felfogás a származás szerinti hierarchián alapuló egyenlőtlenségeket az érdem szerinti egyenlőtlenséggel váltja fel. Ennek fő üzenete az előnyös és kevésbé előnyös csoportok (és pozíciók) társadalmi összetételének megváltoztatása az iskolarendszer közvetítésével. Így ez a felfogás a társadalmi egyenlötlenség kérdéskörét érintetlenül hagyja.

Az egyéni érdemek, teljesítmények különbözősége szerinti társadalmi felemelkedés (vagy süllyedés) előtérbe helyezte az iskolának a társadalmihely-változtatásban, a mobilitásban betöltött funkcióját. ${ }^{4}$ A meritokratikus gondolkodásmód az igazságosabb és egyenlőbb esélyeket biztosító társadalom legfontosabb eszközének, a társadalmi mobilitás csatornájának tételezte az iskolát. Mindezek eredményeképpen a társadalmi esélyek új perspektívája kezdett formálódni. Ehhez nagymértékben hozzájárult a tudományok gyors ütemben meginduló fejlődése is. Az új felfedezések, ismeretek, a rohamosan sokszorozódó tudásanyag megismertetésére és átadására az iskolarendszer biztosított lehetőséget. Az ott elsajátított tudás a későbbi társadalmi presztízs, a hatalom ígéretét hordozta ma- 
gában, mégpedig a hagyományosan kialakult társadalmi hierarchia ellenében is. Így az iskola már nem csupán esélyteremtőként, hanem az objektív és előítélet-mentes tudáselsajátítás területeként is társadalmi szerepre tett szert. Ugyanakkor az iparosodás, az urbanizáció következtében megnőtt az igény arra is, hogy a nagyobb hozzáértést kívánó munkafolyamatokban magasabb elméleti-technikai tudással rendelkező munkaerőre lehessen számítani. E szükséglet kielégítése is a család és a társadalom közötti közvetítőre, az iskolarendszerre hárult. $\mathrm{E}$ folyamat eredményeképpen alakult ki az iskola másik funkciója, a mindenkori társadalmi igényeknek megfelelő munkaerőutánpótlás biztosítása.

Az iskola funkcionális kettőssége: a magas szintű tudásközvetítés és a szakképzett munkaerőről való gondoskodás az iskolarendszer különböző típusú szerkezeti tagoltságához vezetett. Az iskoláztatáshoz való egyenlő hozzáférés elve/gyakorlata és az igazságos esélyelosztás kívánalma kezdett eltávolodni egymástól. Az új jelenség az iskola ki- és elválasztó mechanizmusaira, a szelekcióra irányította a figyelmet. Kiderült ugyanis, hogy az iskolához való egyenlő hozzáférés nem változtatta meg tömegméretekben és alapvetően a felnövekvő generációk szüleikhez viszonyított társadalmi státusát, és a különböző típusú iskolákban tanuló diákok társadalmi összetétele is nagyrészt szinkronban maradt az adott iskolatípus befejezésével elérhető társadalmi státussal. Mindkét jelenség az iskoláztatás általi intergenerációs mobilitáshoz kapcsolódó alapvető hiedelmeket ingatta meg. Az okkeresés kezdetben a nyílt szelekcióra, az iskolarendszer szerkezeti tagoltságára hárította a felelősséget. Csakhogy a kutatások feltárták, hogy az intergenerációs mobilitás akkor is korlátozott, ha az iskolarendszer viszonylag rövid, 4 vagy 6 éves képzés után kínál különböző lehetőséget, és akkor is, ha 8 vagy 10 év után jelennek meg a választási irányok. Míg azonban az első esetben a struktúra nyíltan vállalja a szelekciót, hiszen korai életkorban írja elő az iskolaválasztás kötelezettségét, addig a második esetben az iskolarendszeren belüli rejtett (latens) szelekciós mechanizmusok múködésével elfedi azt. Így vált a nevelésszociológiai kutatások meghatározó területévé az ezen mechanizmusok minél szélesebb körü és teljesebb feltárására törekvés. ${ }^{5}$ 
Durkheim már a 20. század elején felhívta a figyelmet az iskoláztatással szembeni túlzott elvárásokra. Azt állította, hogy az oktatás az embereket nem olyanná formálja, amilyenek természetüknél fogva lehetnének vagy amilyenek szeretnének lenni, hanem olyanra, amilyenre a társadalomnak szüksége van. ${ }^{6}$ Ezzel a megállapításával tulajdonképpen nem csak a nevelésszociológiai kérdésfeltevések jogosultságát teremtette meg, hanem a kutatások irányait is kijelölte.

Összegezve: a nevelésszociológiai kutatások a társadalmi egyenlőtlenségek, a mobilitás és a szelekció problematikájának összekapcsolásával válaszokat keresnek a következő kérdésekre. Miért nem elegendő a jogegyenlőség önmagában az élethelyzetek különbözőségeiből adódó társadalmi egyenlőtlenségek felülírására? Milyen folyamatokkal magyarázható, hogy az iskola a társadalom egyenlő esélyeket hirdető alrendszereként nem képes az egyenlőtlenségrendszer megváltoztatására vagy kompenzálására?

\section{A társadalmi egyenlőtlenségektől az esélykülönbségekig}

Európában a társadalmi osztályok hierarchiája és összetétele határozta meg az egyenlőtlenségekről való gondolkodást. ${ }^{7} \mathrm{~A}$ társadalom szerkezetének minél pontosabb feltárására irányuló szociológiai vizsgálatok azonban már egy többdimenziós társadalmi teret jelenítettek meg. Az egyes dimenziók összekapcsolódása és egymáshoz való viszonya más-más módon jelölte ki az egyének és a csoportok társadalomban elfoglalt helyét, így különböző típusú és különböző súlyú egyenlőtlenségek váltak kimutathatókká. Ezen kutatások húzták alá elsőként, hogy a társadalmi egyenlőtlenség-rendszerben elfoglalt helyben a kulturális dimenzió játszik kiemelkedő és meghatározó szerepet, melynek tartalmát (és mérhetőségét) az iskolai végzettség és az ahhoz kapcsolható életvitel, életstílus adja. ${ }^{8}$

Ennek eredményeképpen a szociokulturális különbségek és az ezekból adódó iskoláztatási problémák feltárásával a nevelésszociológiai vizsgálatokban is új megvilágításba került az egyenlőtlenségek kérdésköre. A szociokulturális egyenlőtlensé- 
gek tükrében ugyanis egymásra lehetett vonatkoztatni a társadalomban betöltött helyet (társadalmi státus) és a tudáshoz való viszonyt (iskolai előmenetel). Lawton (1968/1974) érdeme, hogy túllép az iskola általános esélyteremtő funkcióján, amikor kutatásaiban összekapcsolja a társadalmi-demográfiai változókat az iskolába való bejutással, a bennmaradással/lemorzsolódással és az iskolai teljesítménnyel. Vizsgálatai egyértelműen kimutatták ezen kapcsolatok szorosságát, ezért az oktathatóság és a tanulási motiváció társadalmi tényezők általi determináltságára következtetett. Az iskolában történő helytállás vonatkozásában társadalmi tényezőnek tekintette a tanulók otthonról hozott értékeit, normáit, a család struktúráját, gyermeknevelési elveit, kommunikációs stílusát. Ezért az iskolai eredményesség elengedhetetlen feltételének tartotta, hogy a pedagógusok tanulóikhoz való viszonyulási stratégiáiban tudatosan is jelen legyen ezen szubkulturális különbségek ismerete. Bernstein (1971/2003:107-126) az iskola által közvetített tudás társadalmi csoportonként egyenlőtlen befogadására keresett magyarázatokat. Kutatásai megerősítették a tanulók által már a családban elsajátított társadalmi tapasztalatok érvényességét és jelentőségét. Ezért arra a következtetésre jutott, hogy először a gyermek kultúrájának kell a tanári tudatba bekerülnie, hogy azután az oktatás-nevelés során a pedagógus kultúrája is a gyermeki tudat részévé válhasson. ${ }^{9}$ Az általa kidolgozott nyelvi kódok elmélete mind az iskolai tudásanyag osztályozásában, mind az iskolai teljesítményekben, az interperszonális kapcsolatok milyenségében magyarázatot adott az iskola által közvetített tudás egyenlőtlen befogadására. Bár kutatási eredményeinek általánosíthatóságával kapcsolatban több ellenvetés is megfogalmazódott, az azonban kétségtelen, hogy az iskolai teljesítmények társadalmi csoportok szerinti különbözőségében az iskola által normaként elfogadott kommunikációs kód is szerepet játszik. (Bernstein, 1971/2003:173-196)

A példaként bemutatott vizsgálati eredmények tanulságait úgy összegezhetjük, hogy a kötelező közoktatás az azonos startvonalról indulással valóban esélyegyenlőséget teremtett, azonban a többdimenziós társadalmi tér élethelyzeteinek különbségeit nem volt képes felülírni. Az iskolában eltöltött évek alatt mindezen különbségek tanulási, tudáselsajátítási, 
viselkedésbeli pedagógiai problémákként egyenlőtlenségekké transzformálódtak. A nevelésszociológiai kutatások jelentőségét ezért ebben a vonatkozásban az adja, hogy a szociokulturális háttérből adódó iskolai problémák feltárásával, értelmezésével és megoldási módok keresésével az esélykülönbségek csökkentéséhez, pedagógiai kezeléséhez járul hozzá.

\section{Főbb elméleti orientációk és kutatási területek}

A nevelésszociológia tudományos megalapozása Európában történt. ${ }^{10}$ Korai képviselői elsősorban az oktatás társadalmi kontrolljához kapcsolódó kérdéseket helyeztek vizsgálataik középpontjába. Az érdekelte őket, hogy az iskolarendszer hogyan szocializálja kompetenssé a jövő állampolgárait, hogyan erősíti meg a társadalomban uralkodó domináns ideológiákat és hogyan gondoskodik az egyének megfelelő társadalmi státusba kerüléséről.

Mivel Durkheim (1922/1980) egyszerre volt szociológus és pedagógus, nem tekinthető véletlennek, hogy ezekben a folyamatokban kitüntetett szerepet tulajdonított az iskolának. Szilárd meggyőződése volt, hogy az intézményes nevelés felelőssége a társadalmak folytonosságának, a társadalmi rendnek a biztosítása. Álláspontja szerint a társadalmi értékek és normák elsősorban az iskolában eltöltött évek során épülnek be a következő generációba. A család és az iskola szocializációban betöltött szerepét taglaló funkcionalista nézőpontú elemzései számos kutatás és elmélet kiindulópontjává váltak. ${ }^{11}$ Külön is kiemeljük máig érvényes megállapítását, melyben azt hangsúlyozza, hogy az iskola mindig az adott társadalom releváns érték- és normarendszerére szocializál, ezért minden egyes iskolarendszer csak saját társadalmával kölcsönhatásban vizsgálható, a következtetések ebben a kontextusban relevánsak. Ugyanakkor a különböző iskolarendszerek összehasonlítása minden társadalomban fejlesztések lehetőségeit teremti meg.

A nevelésszociológiai kutatások haszonelvü (utilitárius) orientációját a közgazdaságtan az emberi tőke elméletével alapozta meg. ${ }^{12}$ Ennek értelmében az oktatás egyéni és társadalmi szinten is gazdasági befektetésnek tekinthető. Ezt igazolja a 
vállalatvezetők növekvő érdeklődése is, ugyanis jövendő munkásaik kompetenciái számukra sem közömbösek. Az iskolában elsajátított tudás azonban nem csak az egyén jövendő társadalmi státusát befolyásolja, hanem társadalmi haszna például a születéskor várható élettartamban, a társadalom tagjainak egészségi állapotában is megmutatkozik. E gondolati bázis nyit utat a későbbiekben az egészség- és nevelésszociológia egymásra reflektálásának is.

A konfliktuselméletek hatását mutatják azok a kutatások, melyek a társadalmi csoportok közötti egyenlőtlenségek iskolán keresztüli újratermelődését vizsgálják. ${ }^{13}$ Arra keresnek válaszokat, hogy az iskolarendszeren belül milyen kulturális ideológiák állandósítják az osztálytársadalmakat, mi a szerepe ebben a folyamatban a pedagógusoknak. Ebben a kontextusban a kapitalista társadalmi rendszer megerősítését és így a kulturális különbségek állandósulását, fenntartását szolgálja az iskolák társadalmi összetételéhez igazodó rejtett tanterv azzal, amilyen módszerekkel tanít a tanár és ahogyan értékeli a tanulókat. ${ }^{14}$

Szociálpszichológiai elméleti háttérrel az iskola világának feltérképezése is megindult. A nevelésszociológiai problémalátásra főleg a szimbolikus interakcionizmus (az emberek közötti kapcsolatok, interakciók kutatása) és a fenomenológia (a mindennapi életvilág vizsgálata) hatott. A kutatók érdeklődése az iskolában eltöltött évek felé fordult: hogyan befolyásolják az egyént, milyen interpretációkat kínálnak a tanulók értékvilágához, attitűdjeikhez és aspirációs hajlamaikhoz. A tanári és tanulói énképek, szerepfelfogások és az iskola feladatainak az egymásra vonatkoztatása különösen a társas helyzetekben múködő tanári elvárások és mintakövetések forrásainak feltárásában hozott új színt a nevelésszociológiai kutatásokba.

A nevelésszociológiai probléma-megfogalmazásokban és a kutatási eredmények értelmezésében a fenti és más elméletek hatásai is felfedezhetők. Ezen orientációk a nevelésszociológia multidiszciplinaritását mutatják és a pedagógiai problémák több szempontú látásmódjához járulnak hozzá. 


\section{Kritikai szociológiai alapú magyarázatok}

Az 1960-as évekre végleg szertefoszlott az az illúzió, miszerint az Európa-szerte kiépült iskolarendszerek alkalmasak és képesek is a társadalmi egyenlőtlenségek felülírására. Bár az iskola társadalmi mobilitásban betöltött esélyteremtő szerepe megkérdőjelezhetetlen volt, a felmerülő problémák az egyenlőtlenségek továbbélésének magyarázatát igényelték. Az 1970-es években a kritikai szociológia égisze alatt erős fellendülés indult, melynek következtében 1980-ra a nevelésszociológia a szociológia egyik legnépszerúbb és legproduktívabb területévé vált. Ez a kritikai szemlélet az iskolát a társadalmi egyenlőtlenségek újratermelődésének paradigmatikus intézményévé avatta. Ezért ebben a kontextusban a kutatások arra irányultak, hogy milyen mechanizmusok segítik a társadalom domináns értékeinek közvetítését az oktatás tartalmában, szervezetében, módszereiben és kommunikációs mintáiban. A különböző típusú szelekciós mechanizmusok feltárásával a 20. század második felére új megvilágításba került az iskola társadalmi mobilitásban játszott szerepe is.

Bourdieu (1978/2003:17, 23-40) különböző szempontok szerint veszi górcső alá az iskola és a társadalom kapcsolatát. Álláspontja szerint minden társadalmi csoport múltja az alatta lévő jövője, aminek következtében az iskoláztatással sem változnak meg a társadalmi csoportok közötti egyenlőtlenségi viszonyok, csupán kulturális feljebbcsúszás, transzláció történik. ${ }^{15}$ Alapvető kérdése, hogy milyen tudatos és főleg nem tudatos stratégiák segítenek a társadalmi egyenlótlenségek fenntartásában és újratermelődésében, miért fogadják el a rossz státusú társadalmi csoportok hosszú távon is az őket deprivációikban újratermelő rendszereket. ${ }^{16} \mathrm{E}$ lényeges kérdések megválaszolásához a fennálló társadalmi struktúra és a társadalmi gyakorlat közötti reláció megragadását leíró kategóriákat dolgoz ki.

Az iskolai szelekciós mechanizmusok feltárását több kritikai indíttatású kutatás is feladatának tartja. Arra a következtetésre jutnak, hogy az iskola a társadalmi különbségeket képességbeli különbségekké transzformálja.

Ez a nem tudatos stratégia érhető tetten az iskola legtágabban értelmezett pedagógiai értékelési rendszerében is. 
Douglas (1969/2003) vizsgálatának középpontjában a tanulók képességei szerint kialakított homogén és heterogén osztályokkal kapcsolatos kérdésfeltevések állnak. A tanuló egyik vagy másik osztályba kerülésével általában az adott csoporttól elvárt tulajdonságokat ölti magára. Ezért az iskolai követelmények teljesítésével kapcsolatos jóslatok a képességek szerint szétválasztott osztályokba sorolás pillanatában már be is teljesednek. Az iskola ezen szervezési elvei következtében azonban a tanulókban rejlő potenciális képességek nagy része veszendőbe megy, eltékozlódik. Douglas a továbbtanulási irányok és a lemorzsolódási adatok ismeretében arra a következtetésre jut, hogy a képességek szerinti szelekció az iskolában latens társadalmi szelekciós mechanizmusként is funkcionál.

A társadalmi kontroll értelmében az iskolákban a középosztály értékrendszerére épülő kultúra közvetítése a norma, ami az érdemjegyekben is visszatükröződik. ${ }^{17} \mathrm{Az}$ iskolában a tanár a fő jutalmazó és büntető. Jutalomra, azaz metakommunikációs megerősítéssel együtt járó jó osztályzatra az a gyerek számíthat, aki az oktatás tartalmában kifejeződő tudást sajátjaként, meghitt ismeretként kezeli. Erre azonban nagy valószínúséggel azok a gyerekek képesek csupán, akiknek a családi szocializáció során elsajátított szubkultúrája nincs távol az oktatás során közvetített tudástól. Mollenhauer (1969/2003) ezért a család nevelési gyakorlatát és az ezt meghatározó társadalmi helyzetet (mint szociokulturális hátteret) kapcsolja az iskola hatékonyságának problémaköréhez. A passzív, családias, életvitelében a jelenre orientált, az alsóbb társadalmi csoportokat jellemző családi nevelési gyakorlat a gyerek alacsonyabb tanulmányi eredményével és ebből adódóan a rövid képzést nyújtó iskolatípusba irányulással jár együtt. Az aktív, személyre irányuló (individualista), jövőre orientált nevelés a középosztály családi nevelésének stílusa. E nevelés következménye a gyerek jó tanulmányi eredménye, majd ebből adódóan a jó iskolatípus választása. Így a társadalmi meghatározottság a szocializáció folyamatában alakul és erősödik, és különböző közvetítő mechanizmusok (pl. a család nevelési stílusa) segítségével válik a társadalmi szelekció szignifikáns tényezőjévé.

Coleman (1968/2003) a serdülők sajátos normái szerint szerveződött iskolai csoportok és az intézményes követelmé- 
nyek közötti kölcsönhatást mutatja be. Az 1960-as években folytatott kutatásai arra irányítják a figyelmet, hogy az iskolák jutalmazási-büntetési struktúrája nem veszi figyelembe a serdülők értékvilágának jellemzőit, és ezzel az oktatás folyamatát gyengíti. A hasonló értékrenden alapuló tudástartalmak mellett nem kevésbé fontos a tanuló és az iskola kommunikációs kódrendszerében meglévő kongruencia. Bernstein (1971/2003:173-196) nyelvi kóddal kapcsolatos kutatásai éppen ennek a problémának a felfejtésére irányultak. A hasonlóság jutalma a jó érdemjegyen túl a tanár és a diák közötti interperszonális kapcsolatok sokszínűsége, a tanórán túli ismeretszerzés lehetősége szervezett vagy kötetlen formában. A kommunikációs kódrendszerek inkongruenciája viszont nemcsak az iskolai előmenetel sikertelenségével büntethet, hanem a tanár-diák közötti kapcsolatok disszonanciájával, az iskolával kapcsolatos negatív érzelmekkel is. Az iskola informális rendszerének latens szelekciós mechanizmusáról, a rejtett tanterv problematikájáról már szóltunk. Ebben a kontextusban azzal egészíthetjük ki a korábbiakat, hogy az iskolán belüli eligazodásra vonatkozó követelmények, szabályok, szokások felismerésében, az azokhoz való adaptálódásban azok a tanulók indulnak nagyobb eséllyel, akik felismerik az implicit üzeneteket, akik számára nem jelent túl nagy problémát a metakommunikációs jelzések, üzenetek dekódolása. Jutalmuk az iskola kultúrájához való alkalmazkodás megtanulása, jó iskolai és osztálylégkör észlelése. Ez az adaptálódási folyamat az előnyös helyzetű társadalmi csoportok gyermekeinek az iskola iránti toleranciájához vezet. A rejtett tanterv fel nem ismerése ugyanakkor az iskolával szembeni intoleranciát erősíti. A különböző jellegű adaptálódási problémákból adódó iskolai büntetés a tanulmányi eredményekben realizálódik.

Ez az iskola belső világában, formális és informális alakulataiban egyaránt jól értelmezhető jutalmazási-büntetési stratégia komoly hatást gyakorol a jövendő életpályára is. Az iskolával szembeni tolerancia a hosszabb képzési időt nyújtó iskolafokozatok igénylésében, míg az intolerancia a rövid képzési ciklusú iskolafokozatok választásában realizálódik. A jutalom és a büntetés itt sem maradhat el. A reciprocitás elve alapján a nagyobb befektetést, a hosszabb képzést és ezzel együtt na- 
gyobb anyagi ráfordítást választók késleltetetten kapják meg jutalmukat. Az iskoláztatás hosszú évei során megszerzett kulturális tőke nagy valószínúséggel jó társadalmi státussá konvertálódik. Ezzel szemben a kevesebb befektetést, a rövid képzést és utána munkába állást választók azonnali jutalma a viszonylag korai életkorban megszerzett anyagi önállóság. E gyors jutalomnak azonban az életpályát tekintve nagy ára van. A rövid idejű képzést igénylő munkák alacsony társadalmi presztízse, a konvertálható tudás hiánya rossz társadalmi státussal bünteti azokat, akik a rövidtávú beruházás stratégiáját alkalmazva döntenek jövendő életpályájukról. ${ }^{18}$

A magyar nevelésszociológiai kutatások kezdete és kibontakozása a nyugat-európai társadalmaktól igencsak eltérő ideológia talaján történt. A korábbiakban megismert elméletek és empirikus kutatások nyílt társadalomkritikája alkalmas volt arra, hogy a „létező szocializmus” kapitalista társadalomkritikáját hitelesítse. Az elméleti és gyakorlati összefüggések magyar viszonyok közötti vizsgálata, az empirikus kutatások adatrendszere azonban nem igazolta vissza a szocialista egyenlőségideológiát. A szakirodalomból jól nyomon követhető, hogy ugyanazon kérdéskör - a társadalom és iskolája közötti összefüggésrendszer vizsgálata - hányféle megközelítést és milyen válaszokat enged meg demokratikus és diktatórikus körülmények között. Ezért a magyar szakirodalomban a kutatásokhoz kapcsolt évszámok egyben politikai jelentést is hordoznak. Társadalomkritika ez is, de jóval rejtettebb, mint ami a külföldi szakirodalomban megjelenik. (Meleg, 2003:199-204)

Ferge Zsuzsa (1972/2003) az iskolarendszer és a társadalom kapcsolatát a hatalom számára is elfogadható módon tálalható problémaként jeleníti meg, miszerint az általános iskoláztatás teljes körúvé tétele nem vezetett el a társadalmi egyenlőséghez. Az iskolák és az osztályok szintjén megvalósított homogenitás és heterogenitás a tanulók társadalmi szelekcióját mutatja, melyet tovább mélyít a települési és a társadalmi hátrány összekapcsolódása. Az 1970-es évek elejének magyarországi diagnózisa az, hogy az iskola kultúraátadó szerepe és társadalmi feladatai között még mindig ellentmondás figyelhető meg. Gazsó Ferenc (1982/2003) már differenciáltabban fogalmaz. Véleménye szerint az iskoláztatás során megnyilvánuló nyílt 
és rejtett esélyegyenlőtlenségek társadalmi tétje a társadalmi struktúra és a társadalmi rétegek nyitottabbá vagy zártabbá válása, melyben a magyarországi települési hierarchia is kiemelt szerepet kap. A társadalmi mobilitás egyenlőtlenségeit a tanulmányi eredmény szerinti irányulás mutatja, így a tanulmányi szelekció egyben társadalmi szelekciót is eredményez a középiskolákban. Róbert Péter (1991/2003) 1945-től az 1980as évek végéig kíséri figyelemmel az iskolai végzettség származás szerinti meghatározottságát, mely szerint a II. világháború utáni társadalmi mobilitásban a származás hatása átmenetileg csökkent Magyarországon. Ugyanakkor arra is felhívja a figyelmet, hogy nemzetközi összehasonlításban ez a tendencia olyan országokban is megfigyelhető, ahol szó sem volt a politikai rendszer változásáról.

A társadalmi egyenlőtlenségek iskolai egyenlőtlenségekké transzformálódásának vizsgálataiban diagnózis és/vagy ok keresés egyaránt megjelenik.

Andor Mihály (1980-81/2003) látlelete a magyar közoktatás 35 évének kritikája. A mennyiségi mutatók helyett az oktatásügy minőségi paramétereit veszi górcső alá, miközben a politikai befolyásolás nyílt és rejtett, közvetlen és közvetett eszközeit is megmutatja. Pap Mária és Pléh Csaba (1972/2003) az iskolába lépés kezdetén meglévő különbségeket, azok okait vizsgálják. Arra keresnek választ, hogy a magyar gyerekeknél is megtalálhatók-e mindazok a különbségek, melyeket Lawton és Bernstein kutatásai tártak fel. A vizsgálat nyílt társadalomkritikai következtetése: hiába ellentétes a két ország társadalmi berendezkedése, a nyelvhasználat szituációhoz kötöttségében a szociális helyzettel összefüggő különbségek ugyanúgy megjelennek, ezért a szociális helyzet és az iskolai sikeresség/sikertelenség összefüggése az 1970-es évek Magyarországának is sajátja.

Meleg Csilla (1991/2003) más tárgykörben vizsgálja iskola és társadalom kapcsolatát. Kutatásai az 'egészségesnek lenni és maradni' vonatkozásában mutatják ki a társadalmi egyenlőtlenségek újratermelődését. Következtetései szerint az egészségértékhez való viszony az iskoláztatás évei alatt transzformálódik társadalmi előnnyé vagy hátránnyá. Ennek okát a köznevelés és az egészségügy együttműködésének 
hiányában és abban látja, hogy egyik szervezet sem dolgozta ki az egészségérték közvetítésének eszközrendszerét. Kozma Tamás (1998/2003) oktatáspolitikai nézőpontból tekint a társadalmi és iskolai egyenlőtlenségekre. Az a kérdése, hogy melyik stratégia célravezetőbb a társadalmi egyenlőtlenségek csökkentésére: az egyének versenyhelyzetére épülő oktatás vagy az intézményes hátránykompenzálás. Az egyik ugyanis az esélyek egyenlővé tételére, a másik pedig az emberek közötti egyenlőségre irányul. E kétféle stratégia kétféle oktatáspolitikája a liberalizmus és a szocializmus. Ezért a fogalmak tisztázását elengedhetetlennek tartja ahhoz, hogy az igazságosság, az egyenlőség, az egyéni szabadság filozófiája és a minőségi oktatás közötti összefüggést értelmezni lehessen.

Összegezve: a kritikai szociológiai alapú kutatások szerint a nem tudatos pályaválasztási, életútkijelölő stratégiák következtében válik az iskolaszerkezet és az iskolával szembeni attitǔd (tolerancia-intolerancia, tanulmányi eredmény, interperszonális kapcsolatok, rejtett tanterv, kommunikációs kódrendszer) egymást erősítve a társadalmi szelekció eszközévé. A kemény iskolakritikákat megfogalmazó kutatások ugyanakkor tényfeltárásukkal, több szempontú problémaláttatásukkal az iskola társadalmi kontextusú diagnózisát adták meg. Eszerint az iskolarendszer mobilitásban betöltött szerepe kétséges, szerkezetének megváltoztatása nem tudja megszüntetni a szelekciót, mert az iskola rejtett mechanizmusai azok, amelyek a fennálló társadalmi egyenlőtlenségeket hosszú távon konzerválják. Az iskola latens folyamatainak láthatóvá tételére törekvés ugyanakkor új magyarázó elveket emelt be a további kutatásokba (pl. szimbolikus tőkék), új szempontokat adott (mentalitásbeli különbségek és időorientációk kapcsolata) és így nagy szerepet játszott a nevelésszociológiai gondolkodásmód paradigmaváltásának az előkészítésében is.

\section{Paradigmaváltás: másként feltett kérdések, új ér- telmezési keretek és a szervezeti nézőpont}

Az eddig bemutatott okkeresések és diagnózisok a további kutatásokat is erősen befolyásolták. A tudományos kérdés azon- 
ban az, hogy más szellemi áramlatok hogyan hatottak a nevelésszociológiai gondolkodásmódra és problémalátásra.

Az 1980-as évek végére a társadalomtudományok gondolkodásmódjában paradigmaváltás történt. ${ }^{19} \mathrm{~A}$ posztmodern paradigma az emberi és a társadalmi kérdések megértéséhez a jelenségek közötti többdimenziós kapcsolatok feltárására irányította a figyelmet, melyhez metodológiai váltást is kapcsolt. A megújulás következtében az addig egyeduralkodó kvantitatív, matematikai-statisztikai módszerek kvalitatív technikákkal és elemzésekkel egészültek ki. ${ }^{20}$ Ezeknek az értelemteremtő és jelentésadó kutatásoknak a kritikai és a reflexív jelleg egyaránt sajátja lett.

A paradigmaváltás a szocializáció két alapvető intézményével, a családdal és az iskolával kapcsolatos problémafelvetésekben is tetten érhető. A nevelésszociológiai vizsgálatokban a társadalmi egyenlőtlenségek, a mobilitás és a szelekció kérdésköre továbbra is meghatározó marad, azonban a figyelem itt is a mélyebb és rejtettebb mechanizmusok feltárására, múködésük megértésére irányul. Ahhoz azonban, hogy a már ismert jelenségek más értelmet is nyerjenek, új és más módon feltett kérdésekre új és más értelmezési keretek között kell a válaszokat keresni.

Kritikai nézőpontból a mobilitás fő trendjei igazolták vissza a társadalmi egyenlőtlenségek iskolán keresztüli újratermelődését. Azonban ha a kérdést úgy tesszük fel, hogy a trendek ellenére miért történik mégis státusváltás, akkor a mobilitás problematikáját a család és az iskola szintjén is más kontextusba helyezzük. Ekkor arra keresünk választ, hogy milyen tényezők együttjárása képes felülírni a szociokulturális előnyt vagy hátrányt, milyen folyamatok eredménye a fő trendektől való eltérés. ${ }^{21}$ Milyen szerepe van ebben a családnak és az iskolai évek történéseinek, társas kapcsolatainak, interperszonális viszonyainak? További kutatások deríthetnek fényt azután arra, hogy ezek az együttjárások és folyamatok modellezhetők-e, a szociokulturális hátrányt csökkentő iskolai gyakorlattá formálhatók-e.

A család vonatkozásában például egy több generációt felölelő kutatás térben és időben terjesztette ki a család szocializációs funkcióit, és ezzel az intergenerációs mobilitást is újraértelmezte. Ebben a kontextusban már az a kérdés, hogy 
a családi generációk egymásra épülésében milyen finomabb mechanizmusoknak köszönhető a régi és az új minták összeillesztése, azaz milyen sajátos adaptivitás mozgatja a családi szocializációs funkciókat. (Boreczky, 2004)

Az iskola vonatkozásában is változatlan kutatói érdeklődés irányul a mobilitásra. Az újraértelmezéseket a társadalom és a szervezetek kapcsolatát vizsgáló azon szociológiai kutatások inspirálták, melyek az iskolát szervezetkénti müködésében a magatartás-irányítás legkeményebb eszközeként aposztrofálták. ${ }^{22}$ A kritikai aspektusú álláspontok vagy a társadalmi egyenlőtlenségeket vagy az iskola belső folyamatait tették felelőssé azért, hogy a különböző társadalmi csoportok gyermekei különbözőképpen profitálnak az iskoláztatás éveiből. Azonban míg a 20. század közepéig az osztálytársadalmak hierarchiáját főleg a gazdasági javak alapján létrejövő különbségek adták, addig a későbbiekben már több dimenzió által tagolt társadalomban zajlanak a mobilitási folyamatok is. Ezért az új válaszok más kérdésfeltevéssel kereshetők. Mi tekinthető iskola és társadalom kapcsolatában elönynek és hátránynak a 21. század elején, ezek mely dimenziókban erősítik és melyekben gyengítik egymás hatását? Hogyan értelmezhető ebben a kontextusban az iskolai előmenetel, a tanulmányi eredmény és a rejtett tanterv?

Belátható, hogy ezekre a kérdésekre új értelmezési keretekben adhatók csak válaszok. A nevelésszociológiai kutatások korábbi meglátásainak, tanulságainak másfajta értelmezéséhez a társadalmi időszemlélet és a hálózatkutatás kínál újabb lehetőségeket. ${ }^{23}$

Az idő legegyszerübben a múlt, a jelen és a jövő képében észlelhető. Társadalmi kontextusban ezek az orientációk többdimenziós időtérré barázdálják a társadalmat. A társadalom időorientációk szerinti elrendeződése csupán különbségeket jelenít meg, melyek nem kapcsolódnak közvetlenül a többdimenziós egyenlőtlenségekkel teli társadalmi térhez. Ezek a különbségek azonban az iskolában értéktartalomra tesznek szert. Az iskola szervezeti felépítésébe és rendjébe szőtt időviszonyok a jövőre orientáltság kitüntetett szerepe által hierarchikus rendszerré, egyenlötlenségekké transzformálják az egymástól csak különböző időviszonyokat. ${ }^{24}$ Ennek függvényében 
a trendekkel ellentétes státusváltások problematikája is más megvilágításba kerül. Arra a kérdésre kell választ keresni, hogy az iskolai szervezet időviszonyainak értelmezési keretében hogyan értelmezhetők a státusváltások. A vonatkoztatási keret és a kérdésfeltevés megváltoztatása $a z$ iskola nevelési rendszerében újraértelmezhető felismerésekhez, majd gyakorlathoz vezet. (Meleg, 2001, 2006:191-205)

A szociokulturális különbségek mélyebb összefüggéseinek feltárása a kritikai nézőpontú vizsgálatoknak köszönhető, melyek a társadalmi előnyök és hátrányok újratermelődését eltérő mentalitással (jelenre-jövőre orientáltság), viselkedésbeli (azonnali és elhalasztott szükségletkielégítés) és teljesítményorientációs különbségekkel (azonnali és késleltetett jutalom) magyarázták. Ha azonban az iskola szervezeti időviszonyainak keretébe helyezzük ezeket az idővonatkozásokat tartalmazó magyarázatokat, akkor a trendekkel ellentétes státusváltások értelmezése pedagógiai beavatkozások sokaságát is kínálja fel.

Nézzünk néhány példát a vonatkoztatási keret megváltoztatására! ${ }^{25}$

Némely kutató abban látja az eltérő iskolai teljesítmények társadalmi tartalmát, hogy az iskola előnyt biztosít a középrétegekre jellemző jövőre orientált szemléletmódnak, és ezáltal kerülnek hátrányba az inkább jelenre orientált, szűkebb időhorizontú alsóbb társadalmi csoportok gyermekei. Az iskola szervezeti időviszonyainak keretében azonban a kérdés már az, hogy a teljesítmények vonatkozásában milyen iskolai folyamatok emelik a jövőorientációt kitüntetett jelentőségűvé. A válaszok az időhorizontok tágításához vezető pedagógiai stratégiák kidolgozásához vezetnek.

Más kutatók viselkedésbeli különbségekkel magyarázzák a tanulmányi eredmények társadalmi tartalmát. Az iskola azt tanulói viselkedésmódot értékeli, amely nem zavarja a tanórát egymás közötti beszélgetésekkel vagy a tanulási kötelezettséget a játéktevékenység elé helyezi. Azaz: az interakciós szükségletek kielégítése nem azonnal, hanem az órák közötti szünetekben, a játéktevékenység pedig a kötelezettségek teljesítése után történik. Ezen magyarázat értelmében az iskola a középrétegek felemelkedéséhez kapcsolódó normatív viselkedésmintát, az elhalasztás képességét díjazza. Az iskolai szer- 
vezet időterében azonban már másként jelenik meg ugyanez a problematika. Az iskola saját időrendje, 'itt és most'-ja írja elő a normakövetést, melyhez képest minden más időbeli halasztást kíván. Az iskolai teljesítmények ezért ebben a vonatkozásban a szükségleteknek az időtartam hosszához kapcsolódó viselkedésbeli megnyilvánulásai, melyek jelentőséget és előnyt hordozó tartalmi többletet adnak az elhalasztott szükségletkielégítésnek. E válasz pedagógiai tartalmát az időbeli halasztás képességének a fejlesztései adhatják.

A társadalmi egyenlőtlenségek és az iskolai teljesítmények egymásra vonatkoztatásának harmadik csoportjához azokat a kutatásokat sorolhatjuk, amelyek a teljesítményorientáció különbözőségeiben látják az iskolai karrier ívének formálódását. Eszerint a jelenre vagy a jövőre orientált szülői mentalitás jelentős befolyást gyakorol a tanulók iskolához és tanuláshoz való attitűdjeire, és ezen attitűdök tantárgyi érdemjegyekben történő realizálódása adja a tanulmányi eredmények társadalmi tartalmát. Az iskola szervezeti kontextusában azonban más értelmet nyer a teljesítményorientáció problematikája is. Mivel az iskola különböző időrelációk megjelenítésének és találkozásának a színtere, ezért az időrelációkhoz kapcsolódó normavédelem jelentőssé és előnyössé emeli a kivárást, a késleltetni tudást. Ezen értelmezés is pedagógiai konzekvenciák levonását sürgeti.

A példák jól mutatják, ahogyan a magyarázatokban rejlő időtartalmak a vonatkoztatási keret megváltoztatásával újraértelmeződnek. Némelyek az iskolai szervezetet átszövő időrelációk függvényében jelentőségre tesznek szert, majd az időrelációk különbségei elönyt hordozó tartalmakkal bövülnek, és ennek következtében az időhöz való viszony mentén egyenlötlenségeket indukálnak. ${ }^{26}$ Amikor tehát nem a társadalmi egyenlőtlenségekhez kapcsoljuk az időorientációs különbségeket, hanem az iskolai szervezet temporális szerkezetében értelmezzük azokat (azaz megváltoztatjuk a vonatkoztatási keretet), akkor az iskola társadalmi szerepe és lehetőségei alapvetően más megvilágításba kerülnek. Míg a kritikai megközelítés szerint az a konklúzió, hogy az iskola alkalmatlan a társadalmi egyenlőtlenségek megváltoztatására, addig a szervezeti nézőpont olyan intézményt mutat fel, amely az időorientációkra fi- 
gyelö pedagógiai stratégiák kidolgozásával a státusváltáshoz is hozzá tud járulni.

Az időfolyamatok befolyásolására, pedagógiai szempontok szerinti rendezésére további kutatási és értelmezési lehetőségeket kínálnak az iskola társas erōterei. Az ezekben formálódó kapcsolatok feltárását a szociálpszichológiai csoportkutatások indították el. A hálózatkutatások eredményeinek adaptálásával, a hálózatos gondolkodással azonban az iskolai csoportformációk is újraértelmezhetők, ezért pedagógiai szempontok szerinti múködtetésük is új lehetőségeket hordoz. (Csermely és mtsai, 2009) Ebben a kontextusban a társas kapcsolatok csomópontjainak feltérképezése jelent pedagógiai feladatot. E csomópontok bizalomszigeteinek a megtalálása olyan hídteremtő kapcsolatokat nyithat meg az iskolában, melyek új csoportképződményeket, új tanári és tanulói szerepfelfogásokat és szereptartalmakat eredményeznek. (Meleg, 2012a)

A bemutatott idő- és hálózati keretekben további kérdések tehetők fel az iskola pedagógiai gyakorlatának újraértelmezésére. Képes-e a pedagógiai szakértelem olyan szervezeti szintü nevelési környezetet teremteni, melyben az iskola időnormája, az egyéni időegységek rugalmassága, az időhorizont tágítása követésre érdemes? Más vonatkozásban pedig az a kérdés, hogy a pedagógiai szakértelem a társas erőterek közvetítésével az egyén számára is beláthatóvá tudja-e tenni, hogy megéri ezekhez igazítania időbeli befektetéseit, megéri elfogadni e normarendszert az iskoláztatás évein jóval túlmutató időbeli tájékozódás iránytüjeként. ${ }^{27}$ Ehhez az iskola szervezeti idejét átszövő késleltetési folyamatok egymásra vonatkoztatása és pedagógiai rendszerbe foglalása szükséges. ${ }^{28}$

\section{A nevelésszociológiai kutatások jövőbeli orientációi}

Az iskola társadalmi kontextusú szemlélete továbbra sem veszít jelentőségéből. Ezt azokkal a társadalmi igényekkel magyarázhatjuk, melyek szerint a társadalmi problémák az oktatási rendszer közvetítésével oldhatók meg. Ezért a nevelésszociológiai kutatások témakörei az alapvető társadalmi problémákra 
irányuló változatlan figyelmet mutatják (társadalmi egyenlőtlenség, mobilitás, szelekció-szegregáció), melyek mellett más, társadalmi problémának tekintett jelenségekre irányuló vizsgálatok (pl. alkohol- és kábítószer-fogyasztás, dohányzás, előítéletesség, többségi-kisebbségi kultúra, tolerancia-intolerancia, szexuális orientáció, egészségesség-életmód-életminőség stb.) is megjelennek. ${ }^{29}$ Ezen tényfeltáró vizsgálatok nagyrészt alátámasztják azt a korábbi összegzést, mely szerint az iskola kevéssé hatékony a társadalmi problémák megoldásában. Ha azonban kilépünk ebből a gondolatkörből, és az iskolai elvárásokhoz más kontextusban közelítünk, akkor az iskola múködéséhez igazított problémakezelés nem csak a pedagógia gyakorlat átrendezéséhez, hanem hosszabb távon társadalmi eredményességéhez is hozzájárulhat.

Kiindulópontnak ebben az esetben is a szervezeti nézőpont tekinthető. A szervezetszociológia fél évszázados történetét áttekintő kiváló elemzés a szervezetek társadalmi szerepét és magatartásirányító erejét összekapcsolva a következőképpen összegez: „A szervezetek korunk legbefolyásosabb tényezői maradnak. Társadalomban játszott szerepük és az általuk megfogalmazott számtalan kihívás - melyben a társadalmi élet minden egyes szegmense érintett - még sohasem volt ennyire jelentős." (Scott, 2004:17) Ebben az értelemben a szervezetekre társadalmi problémák kezelésének színtereiként tekintünk. Minden szervezet azonban csakis saját kompetenciáival képes hozzájárulni a probléma megoldásához. Igaz ez az iskolára is, melynek ebben a kontextusban az a feladata, hogy a társadalmi problémákra pedagógiai válaszokat keressen. Példaként arra a kutatásra utalhatunk, mely abból indult ki, hogy a magyarországi felnőtt lakosság egészségi állapotát mutató statisztikai adatok társadalmi problémát jeleztek. Az erre adott pedagógiai válasz az iskolai szervezetfejlesztés volt. Ennek során az iskolai szervezet magatartás-irányító erejének és időorientációinak egymásra vonatkoztatásával pedagógiai kompetenciák sokasága értelmezte újra az iskolai egészségnevelés gyakorlatát, hosszú távon az életminőségre gyakorolt hatását. (Meleg, 2006)

Az iskola szervezeti kontextusában azonban számtalan releváns pedagógiai válasz rejlik, melyek felfejtése még várat magára. Ehhez kínálnak lehetőséget a szervezeti tudást vizsgá- 
ló közgazdasági modellek. Iskolai adaptálásukat az indokolja, hogy szervezeti szinten kínálják fel a magatartás- és viselkedésformálás befolyásolását. Az iskolai szervezetben zajló mindennapi események folytonossága tudástőkévé konvertálja a megélt történéseket, tapasztalatokat, ezért pedagógiai választ az igényel, hogy ez a tudástőke hogyan kamatoztatható az iskolai gyakorlatban, milyen folyamatok hatására válhat fejlesztő, tényleges erőforrássá. A válaszok az iskola szervezeti tudásának felfejtésével kereshetők. (Meleg, 2013)

A nevelésszociológiai kutatások régi-új problematikája a migránsok gyermekeinek szocializációja. Az emberi és társadalmi tőkére, a családstruktúrára, a közösségszerveződésre, a kulturális és nyelvi mintákra épülő magyarázatokra eddig egyetlen ország sem tudott autentikus pedagógiai válaszokat adni. ${ }^{30}$ Ugyanakkor nem csak a napjainkban zajló modern kori népvándorlás terhel világszerte újabb problémákat az oktatási rendszerekre. A társadalmakban zajló változások a családstruktúrát is rendkívül sokszínúvé alakították, melynek iskolai konzekvenciáira a pedagógiai gyakorlatnak válaszolnia kell. Ugyancsak pedagógiai válaszokat igényel a mai iskolás korosztályok érték- és normavilágának, ebből adódóan az ezekhez illeszkedő új pedagógus- és tanulószerepeknek kutatásokkal történő feltárása. Bár a nevelésszociológiai kutatásokban és a gyakorlatban alternatív pedagógiai stratégiák is feltűnnek (pl. Westlund, 2007 és http://qz.com/377742/), az oktatás egészét átfogó megoldásoktól még nagyon távol vagyunk.

A kutatások egészen új irányát jelöli ki a technológiai fejlödés. Válaszokat kellene kapnunk arra, hogy a digitális világ milyen hatást gyakorol az iskola múködésére, újraíró, felülíró vagy éppen kiegyenlítő dimenziót jelent-e az egyenlőtlenségek, az esélykülönbségek vonatkozásában. Válaszra vár az is, hogy a technológiai változások gyorsaságához kell-e az iskolai gyakorlatot illeszteni, azaz teremthető-e eredményes kapcsolat a digitális világ és a pedagógiai stratégiák között. Újra kell-e definiálni ehhez a tanulási folyamatot, a tanár- és tanulószerepeket? Ma még nagyon keveset tudunk a digitalizáció hosszabb távú következményeiről, így arról is, hogy az oktatási rendszerrel való kapcsolat feltárásához milyen releváns kérdésekkel járulhatnak hozzá a nevelésszociológia kutatói világszerte. 
Az eddigieket úgy összegezhetjük, hogy a nevelésszociológiai kutatások irányait változatlanul a társadalmi problémák kezelésének iskolai reflexiói jelölik ki. A régi, ám továbbra is alapvető problémák új értelmezési keretbe helyezése és az új problémák iskolai értelmezése azonban mind a kutatások, mind az iskolai gyakorlat megújítását sürgetik.

Amerikai nevelésszociológusok szervezeti szinten vizsgálták az iskola strukturális elrendeződésének okait és következményeit, beleértve ebbe olyan tényezőket is mint a vezetés, a tanárok együttmúködésének stílusa és a tanárok hatékonysága. Kutatásuk az alacsonyabb létszámú, kisebb iskolákban magasabb tanulmányi eredményeket mutatott ki, mint az amerikai városok többségében múködő nagyobb iskolákban. A jobb tanulmányi eredmények elérésében döntő szerepet játszott az a kölcsönhatás, melynek következtében a kisebb iskolák tanárai közötti magas szintű együttműködés és a diákoktól elvárt teljesítmény egymást erősítővé tudott válni. (Gamoran és mtsai, 2000) ${ }^{31}$ Más kutatások az iskolai szervezet és a diákok tanulási folyamatainak összekapcsolásával mutatták ki a szervezeti magatartásformálás hatékonyságát. (Hedges és Schneider, 2005)

\section{Végső összegzésként a jövő tanárainak}

A nemzetközi összehasonlításokra is alkalmas életminőségindexekben többek között megbirkózási stratégiák alkalmazásaira, érzelmi stabilitásra, interperszonális-kommunikációs készségekre, a bizalom képességére vonatkozó adatok sűrüsödnek. ${ }^{32}$ Ezért a társadalmi tőke termeléséhez járul hozzá az a pedagógiai gyakorlat, amely az iskola szereplőinek életvezetésébe szervezetileg építi be a kapcsolatok kialakításának, fenntartásának, problémakezelésének algoritmusait, a kapcsolati hálókban való eligazodás és rugalmas közlekedés képességeit. 


\section{Jegyzetek}

1 A szociológiai aspektusú, ám nevelési-oktatási tartalmú szakterület Magyarországon pedagógiai szociológia néven kezdte meg tudományági karrierjét az 1960-as években, majd nevelés- és/vagy oktatásszociológia elnevezéssel önálló pedagógiai diszciplínává vált. A későbbiekben ez a fajta problémalátás egyre több szaktudomány tudásanyagát használta fel társadalmi kontextusú vizsgálataiban. Így vált interdiszciplináris szaktudományból multidiszciplinárissá (pl. filozófia, egészségtudomány, közgazdaságtan, antropológia, szociálpszichológia stb.). Jelen munkánkban a nevelésszociológia elnevezést használjuk, melynek problémakezelése multidiszciplináris. A nevelésszociológia nézőpontja az iskolával és iskoláztatással kapcsolatos kérdések társadalmi kontextusba helyezése, mely az oktatási folyamatot is magában foglalja. (Megjegyezzük, hogy az angol nyelvú szakirodalomban az oktatást és a nevelést is az 'education' szó jelöli.)

2 Az iskola fogalma jelen munkában mindig a közoktatási intézményrendszerre vonatkozik.

3 A történelmi háttér és a társadalmi folyamatok egymásra hatásáról részletesen lásd Meleg szerk., 2003:11-19.

4 Mobilitáson a társadalmi egyenlőtlenség-rendszerben elfoglalt hely vagy helyzet megváltoztatását értjük. Ennek értelmében beszélünk vertikális, felfelé vagy lefelé mobilitásról (süllyedésről), generációk közötti (intergenerációs, amikor a szülőkhöz képest változik a következő generáció helyzete) vagy generáción belüli (intragenerációs, amikor az egyén saját korábbi helyzetéhez képest változtatja a helyzetét) mobilitásról, illetve kilépési vagy belépési mobilitásról (amikor egy társadalmon belül vagy társadalmak között az egyes társadalmi csoportok egymáshoz viszonyított arányváltozásait vizsgáljuk). Horizontális mobilitás: a generációk között foglalkozásváltás történik ugyan, azonban ez nem eredményezi az egyenlőtlenség-rendszerben elfoglalt korábbi hely megváltoztatását.

5 A rejtett (latens) szelekciós mechanizmusokkal (pl. nyelvi, kapcsolati stb.) a későbbiekben részletesen foglalkozunk.

6 Durkheim, E. (1858-1917): Education et sociologie, Paris, Alcan, 1922 c. posztumusz múvében állította a szociológiát a pedagógia szolgálatába, és a két tudomány összekapcsolásával alapozta meg azt a tudományágat, amelyet ma nevelésszociológiának nevezünk. (Magyarul: Nevelés és szociológia, 1980) A 'nevelésszociológia' elnevezést Comte, A. (1798-1857) használta első- 
ként; a nevelést-oktatást tanulmányozó társadalomtudományi megközelítések királynőjének tartotta.

7 Összehasonlítva: az amerikai nevelésszociológiai vizsgálatok is a társadalmi egyenlőtlenségből indulnak ki, azonban az európaitól eltérő társadalomfejlődés következtében Amerikában a nemi és a faji diszkrimináció problémái kerültek a középpontba. (Wagenaar, 2007:315)

8 A többdimenziós társadalmi térhez kapcsolódó egyenlőtlenségek magyar vonatkozásait lásd Kolosi (1987), illetve Róbert (1991/2003). A vizsgált dimenziók a következők: fogyasztás, érdekérvényesítés, lakáskörülmények, településviszonyok, foglalkozásszerkezetben elfoglalt hely, anyagiak és a kultúra.

9 E gondolat kultúraazonos pedagógia néven kerül be később a magyar nevelésszociológiai szakirodalomba. (Boreczky, 2000)

10 Az amerikai nevelésszociológia más utakon járt. Az 1960-as évekig kevéssé koncentrált az elméletekre, sokkal inkább az iskolán belüli magatartásra. Az iskolát a szociológusok a tanárok, a tanulók, a kormányzat és a helyi közösség befolyásgyakorló, egymással versengő érdekcsoportjaiként elemezték. Elmélet és empirikus kutatások összekapcsolódása akkor következett be, amikor az 1960-as évek után az iskola mint szervezet került a figyelem középpontjába. (Wagenaar, 2007:311)

11 Funkcionalista gondolkodásmód: a társadalom egyes részei hogyan járulnak hozzá az egész társadalom stabilitásához. E nézőpont szerint ebben az intézményeknek meghatározó szerepe van.

12 A modern közgazdasági emberi tőkeelmélet ('human capital') az 1960-as években fejlődött ki. Az emberi tudás gazdasági értelemben vett értékét és ezért az oktatásba történő befektetés univerzális megtérülését feltételezte. A költség-haszon elemzések adatai azonban azt mutatták, hogy a befektetések megtérülése nagyon különböző, mert mindegyik oktatási szinten nemi, területi és etnikumok szerinti különbözőségek is fellelhetők. (Schultz, 1961/1983). E nézőpont alapozza meg a szimbolikus tőkeelméleti magyarázatokat (pl. Pusztai, 2009).

13 Konfliktuselméletek: a társadalmak jellemezője a konfliktus. Marx (1818-1883) és a neomarxisták az uralkodó és az elnyomott osztály között, Pareto (1848-1923) a hatalmon lévő régi és a hatalom megszerzésére törekvő új elit közötti harcban látja az alapvető konfliktust.

14 Rejtett tanterv: élmények, tapasztalatok, viselkedésmódok, ismeretek összessége, olyan tudás, ami nem szerepel az iskola hivatalos tantervében. Nem tantárgyi teljesítmény, ugyanakkor a tanári értékelés egyik fő tényezője az intézményi normák és 
a pedagógus elvárásaihoz való alkalmazkodás vonatkozásában. (Anyon, 1980) Magyarul lásd Szabó L. T. (1988/2003).

15 Kulturális feljebbcsúszás, transzláció: az iskolázottság lehetőséget teremt ugyan a felemelkedésre, ez azonban úgy realizálódik, hogy minden társadalmi csoport a felette lévő csoport helyére kerül. Ez nem mobilitás, mert a csoportok közötti egyenlőtlenségi viszonyok nem változnak. Ebben a vonatkozásban kivételt képez az elit, melynek történelmi hivatása a ritkaságértékek megtalálása. Így biztosítja az alatta lévő csoporttól való társadalmi távolságát.

16 Depriváció ('megfosztottság'): a többdimenziós egyenlőtlenségekkel teli társadalmi térben minden dimenzióban a leghátrányosabb társadalmi helyzet. A deprivációnak csak az egyik dimenziója az anyagi helyzet. A szegénység a hátrányos helyzet anyagiakban megragadható egydimenziós kifejeződése, míg a depriváció fogalma az összes lényeges élethelyzetben megmutatkozó előnytelen helyzetet, így pl. a kulturális hátrányt is tartalmazza.

17 Szociológiai értelemben a mindenkori középosztály felfelé törekvésében ragadható meg a társadalmi haladás. Ehhez a törekvéshez az az életvitel és gondolkodásmód társul, mely a jövőben várható előnyök érdekében a jelenben visszafogottságot, aszkézist tanúsít. (Weber, 1934/1982)

18 E problematika nevelésszociológiai vonatkozásait lásd Meleg (1991/2003).

19 Paradigma: egy tudományterület adott korszakban és adott időpontban általánosan elfogadott nézetei, fogalommeghatározásai. Paradigmaváltás: az előbbiekben bekövetkező alapvető változás, gondolkodásmód-váltás.

20 A folyamatról részletesen lásd Meleg (2006:15-22). A kvalitatív kutatásokról lásd Silverman (1997) és Szabolcs (2001). Kvalitatív módszerek pl. én-elbeszélések, történeti narrativák, élettörténetek, önéletrajzi anyagok, etnográfiai megközelítések, résztvevő megfigyelések, tartalom- és diskurzuselemzések, mélyinterjúk, esettanulmányok. Az esettanulmányokra és az azokban alkalmazott kvalitatív módszerek kombinációira a család és az iskola esetében lásd Boreczky és mtsai (2007:66-194) és Meleg (2006: 93-178).

21 Amikor státusváltásról beszélünk, akkor kétirányú, felfelé és lefelé irányuló mozgást értünk ezen. A fő trendekbe nem illeszkedő folyamatok vizsgálatakor a többdimenziós egyenlőtlenségrendszer hasonló szintjein elhelyezkedőknek a trendekkel ellentétes státusváltásai igényelnek válaszokat (tehát az előnyös 
csoportokba tartozók gyermekeinek lefelé mobilitása és a hátrányos csoportok felfelé mobilitása).

22 Az iskola szervezetkénti múködésének első vizsgálatairól lásd Kozma $(1975,1985)$. Az iskola múködésének szervezeti kontextusba helyezésére és az ahhoz kapcsolható értelmezésekre a későbbiekben visszatérünk.

23 Az időszemléletű nevelésszociológiai kutatások megtervezéséhez lásd Zimbardo és Boyd (2012), a hálózatkutatási szempontok alkalmazásához lásd Christakis és Fowler (2010).

24 Az iskola lineáris ideje az iskolai évek és az iskolafokozatok egymásra épülése. Az iskola ciklikus ideje a rendszeres ismétlődéseket jelenti: pl. a tanév szerveződése és szünetekkel tagolódása, a tanórák órarend szerinti elrendeződése stb. Ehhez társul mindezeknek a társas terekben történő szinkronizációja. Az iskola időviszonyairól részletesen lásd Meleg (2006:23-45).

25 Ennek részletes bemutatását lásd Meleg (2009).

26 A cigány gyerekek időszocializációját Forray (2009) és Meleg (2012b) más-más értelmezési keretbe helyezi. Az egyik keretben adott magyarázat szerint az iskola időnormái fogságba ejtik a szabadságot, míg a másik keret magyarázata szerint az időkezelés autonómiája adhat csak önértékelt szabadságot, melynek megtanulásához, mentalitássá formálódásához az iskolán keresztül vezet út.

27 Ebben a vonatkozásban új és izgalmas kutatási kérdéseket vet fel a szakképzés moduláris átalakítása, a felsőoktatásban bevezetett kreditrendszer, az élethosszig tartó tanulás, melyek bizonyos értelemben az idő tervezésének normatív jellegét eliminálják. Ezért nevelésszociológiai kutatási feladat annak feltárása, hogy ezek a változások hogyan befolyásolják az iskola szervezeti idejét.

28 Az iskola időrelációinak felfejtéséről, és ennek kapcsán a késleltetések sokaságát kikényszerítő idő láthatóvá tételéről, összehangolásáról valamint operacionalizálásáról lásd Meleg, 2006.

29 Ezen kutatások a hazai pedagógiai és szociológiai folyóiratokból megismerhetők, a szakcikkek irodalomjegyzékei a téma nemzetközi beágyazottságairól is tájékoztatnak (Magyar Pedagógia, Új Pedagógiai Szemle, Iskolakultúra, Educatio, Századvég, Szociológiai Szemle).

30 Amerikában a No Child Left Behind Act (2002) csillantotta fel a reményeket, azonban a kutatások nem igazolták vissza ezeket. Anglia és Franciaország sem talált még választ a migránsok 2. és 3. generációjának társadalmi beilleszkedési problémáira.

31 A Gates Alapítvány ezért a továbbiakban a nagyobb iskolák ki- 
sebb egységekre osztását támogatta Amerikában. (Bill and Melinda Gates Foundation, http://www.gatesfoundation.org)

32 Az életminőség kutatási irányainak és mérőeszközeinek legteljesebb leírását Veenhoven adja. Ő dolgozta ki 1996-ban a nemzetközi összehasonlításokra is alkalmas speciális életminőségmutatót, a „boldog életévek-indexet”. (Veenhoven, 2007)

\section{Irodalomjegyzék}

Andor Mihály (1980-81/2003): Dolgozat az iskoláról. In: Meleg Cs. (szerk.) Iskola és társadalom. Dialóg Campus, Budapest-Pécs, 291-326.

Anyon, J. (1980): Social Class and the Hidden Curriculum of Work. Journal of Education, Vol. 162, no. 1, Winter, 67-92. Bernstein, B. (1971/2003): Az iskolai tudásanyag osztályozásáról és kereteiről. In: Meleg Cs. (szerk.) Iskola és társadalom. Dialóg Campus, Budapest-Pécs, 107-126.

Bernstein, B. (1971/2003): Nyelvi szocializáció és oktathatóság. In: Meleg Cs. (szerk.) Iskola és társadalom. Dialóg Campus, Budapest-Pécs, 173-196.

Boreczky Ágnes (2000): Kultúraazonos pedagógia. Új Pedagógiai Szemle, 7-8, 81-92.

Boreczky Ágnes (2004): A szimbolikus család. Gondolat Kiadó, Budapest.

Boreczky Ágnes és mtsai (2007): Családok távolból és félközelből. Családok tegnap és ma. Gondolat Kiadó, Budapest.

Bourdieu, P. (1978/2003): Az oktatási rendszer ideologikus funkciója. Vagyoni struktúrák és reprodukciós stratégiák. In: Meleg Cs. (szerk.) Iskola és társadalom. Dialóg Campus, Budapest-Pécs, 17, 23-40., 73-87.

Christakis, N. A. és Fowler, J. H. (2010): Kapcsolatok hálójában. Typotex Kiadó, Budapest.

Coleman, J. S. (1968/2003): Iskolai teljesítmény és versenystruktúra. In: Meleg Cs. (szerk.) Iskola és társadalom. Dialóg Campus, Budapest-Pécs, 159-172.

Csermely Péter és mtsai (2009): Hogyan küzdik le a válságokat a biológiai hálózatok, és mit tanulhatunk tőlük? Magyar Tudomány, 11, 1381-1389. 
Douglas, J. W. B. (1969/2003): A tanulók képességek szerinti elosztása. In: Meleg Cs. (szerk.) Iskola és társadalom. Dialóg Campus, Budapest-Pécs, 147-158.

Durkheim, E. (1922/1980): Nevelés és szociológia, Tankönyvkiadó, Budapest.

Ferge Zsuzsa (1972/2003): A társadalmi struktúra és az iskolarendszer közötti néhány összefüggés. In: Meleg Cs. (szerk.) Iskola és társadalom. Dialóg Campus, BudapestPécs, 207-231.

Forray R. Katalin (2009): Az idő fogságától szabadon. In: Pusztai G. és Rébay M. (szerk.) Kié az oktatáskutatás? Csokonai Kiadó, Debrecen, 46-53.

Gamoran, A., Secada, W. G. és Marratt, C. B. (2000): The Organizational Context of Teaching and Learning: Changing Theoretical Perspectives. In: Hallinan, M. T. (szerk.) Handbook of the Sociology of Education, Kluwer, 37-64.

Gazsó Ferenc (1982/2003): Az esélyegyenlőtlenségek és az iskola. In: Meleg Cs. (szerk.) Iskola és társadalom. Dialóg Campus, Budapest-Pécs, 233-244.

Hedges, L. V. és Schneider, B. (2005, szerk.): The Social Organization of Schooling. SAGE Publications. http:// qz.com/377742/this-school-in-norway-abandonedteaching-subjects-40-years-ago (2015. 04. 28.)

Kolosi Tamás (1987): Tagolt társadalom. Gondolat, Budapest. Kozma Tamás (1998/2003): Szabadság vagy igazság? In: Meleg Cs. (szerk.) Iskola és társadalom. Dialóg Campus, Budapest-Pécs, 459-477.

Lawton, D. (1968/1974): Társadalmi osztály, nyelv és oktatás. Gondolat, Budapest.

Meleg Csilla (1991/2003): Egészségérték és intézményes befolyásolás. In: Meleg Cs. (szerk.) Iskola és társadalom. Dialóg Campus, Budapest-Pécs, 349-359.

Meleg Csilla (2002): Iskolai egészségnevelés: a feladat újrafogalmazása. Magyar Pedagógia, 1., 11-29.

Meleg Csilla (2003, szerk.): Iskola és társadalom. Dialóg Campus, Budapest-Pécs.

Meleg Csilla (2006): Az iskola időarcai. Dialóg Campus, Budapest-Pécs. 
Meleg Csilla (2009): Időorientációk és esélykülönbségek. In: Pusztai G. és Rébay M. (szerk.) Kié az oktatáskutatás? Csokonai Kiadó, Debrecen, 32-46.

Meleg Csilla (2012a): A bizalom hálójában - társadalmi nézőpontok. JURA, 18. évf. 1., 72-77.

Meleg Csilla (2012b): Az idő szövetében - szabadon. In: Orsós A. és Trendl F. (szerk.) Útjelzők. Pécsi Tudományegyetem BTK, Pécs, 178-187.

Meleg Csilla (2013): Pedagógiai probléma - szervezeti válasz. Az egészségnevelés példája. Educatio, II. 213-223.

Mollenhauer, K. (1969/2003): Szocializáció és iskolai eredmény. In: Meleg Cs. (szerk.) Iskola és társadalom. Dialóg Campus, Budapest-Pécs, 129-146.

Pap Mária és Pléh Csaba (1972/2003): A szociális helyzet és a beszéd összefüggései az iskoláskor kezdetén. In: Meleg Cs. (szerk.) Iskola és társadalom. Dialóg Campus, BudapestPécs, 327-336.

Pusztai Gabriella (2009): A társadalmi tőke és az iskola. Új Mandátum Könyvkiadó, Budapest.

Róbert Péter (1991/2003): Egyenlőtlen esélyek az iskolai képzésben - Az iskolai esélyek változása az 1980-as évek végéig. In: Meleg Cs. (szerk.) Iskola és társadalom. Dialóg Campus, Budapest-Pécs, 245-274.

Schultz, T. W. (1961/1983): Beruházás az emberi tőkébe. Közgazdasági és Jogi Könyvkiadó, Budapest.

Scott, W. A. (2004): Social Network Analysis. SAGE Publications. Silverman, D. (1997, szerk.): Qualitative research - Theory, Method and Practice. SAGE Publications.

Szabó László Tamás (1988/2003): A „rejtett tanterv”. In: Meleg Cs. (szerk.) Iskola és társadalom. Dialóg Campus, Budapest-Pécs, 337-347.

Szabolcs Éva (2001): Kvalitatív kutatási metodológia a pedagógiában. Müszaki Könyvkiadó, Budapest.

Veenhoven, R. (2007): Quality-of-Life Research. In: Bryant, C. D. és Peck, D. L. (szerk.) 21st Century Sociology. A Reference Handbook. SAGE Publications, Vol. 2., 54-63.

Wagenaar, Th. C. (2007): The Sociology of Education. In: Bryant, C. D. és Peck, D. L. (szerk.) 21st Century Sociology. A Reference Handbook. SAGE Publications, Vol. 1. 311-318. 
Weber, M. (1934/1982): A protestáns etika és a kapitalizmus szelleme: Vallásszociológiai írások. Gondolat Kiadó, Budapest.

Westlund, I. (2007): Reconstructed task orientation and local time governance in compulsory schools: the Swedish case. British Journal of Sociology of Education, 28., 783-796.

Zimbardo, P. és Boyd, J. (2012): Időparadoxon. HVG Kiadó Zrt., Budapest. 



\title{
BIGAZZI SÁRA
}

\section{Tudás és kontextus: a szociális reprezentáció elmélete}

\author{
A kislány még csak négyéves volt, emlékei bizo- \\ nyára összemosódtak, s az anyja, hogy tudatosítsa \\ benne a küszöbön álló változást, odavitte a szöges- \\ drót kerítéshez, és messziről megmutatta neki a \\ szerelvényt. \\ - Nem is örülsz? Ez a vonat visz haza. \\ - És akkor ott mi lesz? \\ - Akkor otthon leszünk. \\ - Mi az, hogy otthon? - kérdezte a gyerek. \\ - Ahol ezelőtt laktunk. \\ - És ott mi van? \\ - Emlékszel még a mackódra? Talán a babáid \\ is megvannak még. \\ - Anyu - kérdezte a gyerek. - Otthon is van- \\ nak örök? \\ - Ott nincsenek. \\ - Akkor - kérdezte a kislány - onnan meg \\ lehet majd szökni?
}

Örkény István: Az Otthon

A következőkben szeretném bemutatni azt a metaelméleti keretet, ami egyszerre magyarázza a kulturális különbségeket a gondolkodásban, a tudás alkotásának esszenciálisan társas jellegét és társadalmi funkcióját, és így, e könyv szempontjából, a nevelés teljesítményéhez és minőségéhez hozzájáruló irányvonalak beazonosításának pszichológiai perspektíváját nyújtja. Majdnem mindig úgy gondolkodunk, érvelünk, kutatunk, oktatunk, nevelünk, hogy saját magunk elvárásait, értelmezéseit, motivációit vetítjük a másikra, viselkedésünk, 
interakcióink tárgyára. Ez a fejezet mint elméleti keret, annak a pszichológiai perspektívának ágyaz meg, amely lehetővé teszi, hogy elgondolkodjunk nemcsak más emberek, gyerekek, felnőttek perspektívájáról, annak miértjeiről, hanem a saját magunkéról is és e két perspektíva közötti lehetőségek feltérképezéséről egyaránt. Egy emberek közötti helyzet kimenete, mint mondjuk a nevelés, oktatás helyzeteié, nem a helyzet objektív jellegzetességeinek eredménye, hanem a helyzetben direkt és indirekt résztvevő emberek perspektíváinak találkozása és egymásra hatásának függvénye. Az itt bemutatásra kerülő elméleti keret azt emeli ki, hogy ezek a perspektívák mennyire kontextusba ágyazott, csoporttagságokhoz, identitásokhoz köthető tartalmak mentén szerveződnek, és hogy ezek a tartalmak funkcionálisak az őket alkalmazók számára. E pszichológiai értelmezés nélkül bármilyen beavatkozás hatékonysága csak részleges lehet.

\section{Bevezetés}

A világot egy szemüvegen keresztül nézzük, másképp nem láthatjuk. Vannak élesebb és kevésbé élesebb szemüvegek, amelyek többet vagy kevesebbet mutatnak a világból, amit nézünk. Ezek a szemüvegek hozzánk nönek, észrevétlenek, alkalmazkodnak ahhoz, amilyenek vagyunk, és ahonnan nézünk. Néha ráérzünk arra, hogy homályos a kép, nem mutat mindent, amit látni szeretnénk, ilyenkor megpróbáljuk lecserélni. Néha mások akarnak ránk eröltetni egy másik szemüveget, de tudjuk, hogy nem áll jól, esetleg nem is arra nézünk, nem azt akarjuk látni, nem a mi szemüvegünk. Néha lecseréljük a szemüvegeinket újakra, amelyek többet és jobban megmutatják azt, amit nézünk. Ez a szemüveg a vélekedéseink, a tudásunk, a reprezentációink mátrixa. Egyszerre határozza meg kik vagyunk, hol, és abból a pontból épp merre nézünk, mit látunk és azzal mit kezdhetünk.

A szociális reprezentáció elmélete viszonylag új paradigma a pszichológiában. A hatvanas években született - egy másik elmélettel, Henri Tajfel szociális identitás elméletével együtt részben válaszként - egy individualizáló, főleg az egyéni mű- 
ködésmódra, az egyéni psziché általánosítható folyamataira összpontosító, a 1930-as évek óta uralkodó leginkább amerikai szociálpszichológiára, ami véleményem szerint, a tudománypolitikában megjelenő hatalmi viszonyok eredményeképpen a mai napig a szociálpszichológia és a pszichológia tudományának főáramlatát képezi.

Ez a fó áramlat, más néven social cognition, olyan fogalmakkal operál, mint attitűd, sztereotípia, előítélet, attribúció (oktulajdonítás), de e fogalmak vizsgálatánál egy társadalmi vákuumban bemért kísérleti paradigmával (Id. Tajfel kritikája, 1981) az egyének pszichológiai folyamatait vizsgálja, leválasztva a folyamatot a tartalomról, amin dolgoznak, kiragadva őket kontextusukból. Célja egy idealizált általánosítás, a világban élő minden egyénre jellemző pszichológiai és társas folyamatok beazonosítása. Szerepeljen itt példaként az egyszerűség kedvéért az az állítás, miszerint a frusztráció agressziót eredményez.

Ugyanakkor az általánosítás mítosza helyett a társadalomtudományok egy másik célja lehetne egy emberi, társas, társadalmi esemény, viselkedés bejóslása; egy ilyen megközelítés dinamikájában és kontextusához igazítva kell, hogy értelmezze a jelenségeket, viselkedést, véleményeket. Azért, hogy előre jelezzen, bejósoljon, ajánlásokat és irányvonalakat határozzon meg és így kihasson mint tudomány a társadalmi valóságra. Ebből a perspektívából tehát a tudás alkotása és a társadalmi kontextus közötti összefonódás megértése elsődleges. Átfordítva a fenti példánkra, ahhoz, hogy az az állítás, miszerint $a$ frusztráció agressziót szül bejósolható legyen, tudnunk kell, hogy egy adott közegben milyen feltételek eredményeznek frusztrációt, és mi minősül agressziónak. Ezek a tartalmak, példánkban a frusztrációt eredményező feltételek és az agresszív viselkedés minősítése az agresszió megjelenésének bejósolásához alapvetően szükségesek. Tartalom (tudás) és forma (a pszichológiai folyamat, viselkedés, egyéni vagy csoportos egyaránt) egyazon érme két oldala. Vagy másképp, ha valaki hisz abban, hogy a boszorkányok léteznek, eszerint fog gondolkodni, élni és cselekedni. De kezdjük az elejéről. 


\section{A szociális reprezentáció}

A reprezentáció egy folyamat, a tudás alkotásának folyamata, ami által a világunkat képező anyagi dolgoknak, absztrakt fogalmaknak és másoknak értelmet tulajdonítunk. Jelentéssel, tartalommal ruházzuk fel a világunkat képező dolgokat és embereket. Ebben a folyamatban beazonosítunk, elnevezünk, mögöttes tartalmakat tulajdonítunk, más dolgokhoz viszonyítunk. A következőkben a szociális reprezentációt, tudást, véleményt egymás szinonimáiként fogom kezelni. A tartalmakra, jelentésekre utaló szavak ezek, amelyek elválaszthatatlanok azoktól az emberektől, akik megalkotják. Az objektum és a szubjektum egymás viszonyulásában létezik.

A valóság számunkra csak közvetetten tapasztalható, mivel bármilyen új, konkrét vagy absztrakt tárgyat csak a már számunkra meglévő jelentéseken keresztül észlelhetünk és értelmezhetünk.

Képzeljük el, hogy sétálunk egy erdöben és leesik az égböl egy tárgy. Első reakciónk, hogy megijedünk és elfutunk. Ha van bennünk elég bátorság, visszamerészkedünk. Ott fekszik elöttünk ez a dolog, és nem tudjuk, mi az. És akkor nem tehetünk mást, elkezdjük értelmezni, jelentéssel ruházzuk fel. Tesszük ezt úgy, hogy a fejünkben összehasonlítjuk a már meglévő dolgokról alkotott tudásunkkal, mihez hasonlít, miben és miben nem.

Így, a legszemélyesebb és legintimebb tapasztalás is társas jellegú, mivel jelentésének konstruálásában összehasonlítjuk, megkülönböztetjük a társasan konstruált és a mindennapokban használt „régi” kategóriákkal, vagyis az érzelmeinkkel öszszefonódott már létező tudásunkkal.

Minden tudás tartalmaz kognitiv elemeket és érzelmeket egyaránt. Szétválasztásuk lehetetlen, mivel velünk való viszonyulásukban jön létre jelentésük. Minél fontosabb számunkra valami, élő vagy élettelen, társadalmi tárgy, annál jobban érzelmekkel telítve jön létre a róla alkotott tudásunk. Ezért van az például, hogy elöitéletes embereknek, hiába adunk információkat az általuk gyülölt emberekröl, csoportokról, azokat nem fogják tudni beépiteni már meglévő tudásukba. Az általuk képviselt tudás e csoportokról identitásukkal összefüggésben 
létezik. Minél fontosabb számukra az adott csoport, annál telítettebb lesz érzelmileg tudásuk, és annál nehezebb lesz a már meglévő tudásukkal ellentétes információkat befogadniuk.

Tudásunk mélyen gyökerezik abban a társadalmi kontextusban, amelyben létrejön, fennmarad, eltűnik vagy átalakul. Az a társadalmi valóság, amelyben egy reprezentáció, egy tudás létrejön, rétegzettségén, kapcsolati hálóin és történelmi keretein keresztül, jelzi a reprezentáció korlátait és lehetséges változásait. A társas/társadalmi tér így egyszerre objektív és szubjektív. Objektív, mert dinamikájában történelmi, politikai és gazdasági elemeket, hatalmi viszonyokat zár magába, amelyek az egyének és csoportok gondolkodásának, viselkedésének, interakciójának, újításának és megőrzésének lehetőségeit korlátozzák és csökkentik. A lehetséges reprezentációk és súlyaik egy adott társadalmi kontextusban létező (hatalmi) viszonyok szimbolikus harcainak eredményei (Jovchelovitch, 1996). Néhány csoportnak több lehetősége van saját verziójának kinyilvánítására és terjesztésére, mint másoknak. Ebből a szempontból a társas/társadalmi tér - intézményesített határok és korlátok tere.

Ez az első olyan pszichológiai elmélet, amelyik számol a hatalommal. A nagyobb hatalommal bíró csoportok befolyásköre nagyobb, több kommunikációs csatornát érnek el, vagy azokat képesek saját maguk számára kiépíteni, mások számára korlátozni, így nagyobb beleszólásuk van abba, mit gondolunk $a$ világról. Több lehetöségük van saját véleményük, tudásuk, reprezentációik elterjesztésére.

A sajtószabadság, az önálló vélemény, a szabad információáramlás azért is fontos szlogenek, mert lehetövé teszik más, új vagy épp kisebbségben lévők tudásához való hozzáférést és így egy nagyobb merítést a lehetséges értelmezések között.

Ezek a határok nem abszolútak, mivel a társas/társadalmi tér szubjektív is, ahol új lehetőségek születhetnek, intézményesített határokat lehet meghaladni és újakat felállítani (Jovchelovitch, 1996). A reprezentációk másokkal történő egyeztetését és lehetséges változását a kommunikáció dialogikus és dialektikus karaktere teszi lehetővé (Markova, 2000). A reprezentáció dinamikussága a kontextusban betöltött funkciójától függ. Egy új gondolat, tudás csak akkor képes 
relevánssá válni, ha azt az abban a társadalmi, gazdasági, történelmi közegben élő emberek képesek beépíteni életükbe.

Jó példa rá, hogy mindig is vannak és voltak olyan tudósok, irók, költők, akik alkotásait évtizedekkel vagy évszázadokkal haláluk után ismertek vagy fogadtak el. Gondolatiságuk, újító megközelítéseik túl messze álltak még az akkori korszellemtöl és a hatalom által képviselt tudástól. Gondoljunk például Giordano Brunóra, akit eretneknek kiáltottak ki, majd tanaiért élve elégettek. Tanai, többek között, hogy a Föld forog a Nap körül, hogy a távoli csillagok akár más napok is lehetnek, az univerzum pedig végtelen, szembement a katolikus egyház által képviselt tudással, miszerint a Föld és az ember körül forog minden, a Föld, amit Isten teremtett, áll az univerzum középén.

Ugyanakkor egy reprezentáció addig múködik, amíg felül nem írja egy olyan új reprezentáció, amely jobban és összefüggéseiben több részét értelmezi számunkra egy jelenségnek (Wagner, 1998), de egy társadalmi tárgy régi és az új reprezentációja együtt is élhetnek, ha a társadalmi kontextusban betöltött funkcióik nem helyettesítik, hanem kiegészítik egymást.

Nekem a macska, leginkább Schrödinger macskája az egyetemen. Az amelyikröl nem lehet tudni, hogy él-e vagy hal, amíg fel nem nyitjuk a dobozt. Szoktam róla beszélni, amikor módszertanórán a kutató kutatásra gyakorolt hatását fejtegetem. Aztán van, amikor hazafele átmegy elöttem egy másik macska, lesem, milyen a színe, tudásomat, ilyenkor az olasz identitásom aktiválja, a fekete macska, jobbról balra szerencsétlenséget hoz. Gyorsan csurit mutatok, ahogy ezt a babonás olaszok is teszik.

\section{A szociális reprezentáció funkciói}

A szociális reprezentációk a tudásra vonatkoznak: az ismeretlent ismerőssé formálják, a régi és az új közötti átmenetet biztosítják, a változásokat funkcionalitásukban magyarázzák.

A szociális reprezentációk összetett funkcióit Bonardi és Roussiau (1999) összegzik könyvükben. Elsősorban informatív funkcióról beszélhetünk: a reprezentációk megmutatják, ma- 
gyarázzák és értelmezik a valóságot, segítik a valóságra irányuló konkrét és koherens viselkedések létrejöttét.

Ugyanazok a jelentéskonstrukciók az alapjai a kommunikációnak és a szociális interakciónak. Irányító funkciójuk által orientálják mind az egyéneket, mind a csoportokat a társadalmi szokások és a mindennapi élet diskurzusai felé. Elfogadott és normatív viselkedésformákat írnak elő. Dinamikájukban meghatározzák a társadalmi szokások lehetséges változásait.

Pár éve történt. Az olasz híradó az esti hírek végén bemondta, hogy a Genf-Róma részecskegyorsítóban egy OPERA nevü kísérlet során a neutrinó nevü részecskék meghaladták a fénysebességet. Ezt a hírt további kommentár követte: „Ha ez a kísérlet valósnak bizonyul, megdöl a fizika egyik alaptörvénye, el kell gondolkodnunk az idő létezéséröl és az ok-okozati viszonyokról, lehet, hogy valójában egyszerre több dimenzióban élünk, nincs idő, ok és okozat, és mindenki máshogy észleli a körülötte lévő világot." Aztán vége lett a híradónak. Elgondolkodtam azon, mit érezhet most az, aki végighallgatta ezeket a híreket. Mennyire képes megkérdőjelezni saját létét? Mennyire vagyunk képesek hirtelen másképp müködni, mint ahogy eddig egy hír hallatán? Mennyire lehet egyik pillanatról a másikra újraírni reprezentációinkat arról, hogy mondjuk, ha vacsora után elmosogatok, annak igenis van következménye, tiszták lesznek a tányérok, amiböl a család a híradó alatt a spagettit ette.

Minden csoportnak megvannak a saját társadalmi szokásai. A reprezentációk identitásfunkciója a csoport kohéziójának terminusaiban értelmezhető, amely kölcsönösen függ a tagok közös és hasonló valóságértelmezésétől. Minél nagyobb a tagok közötti konszenzus arról, hogyan értelmezzék a valóságot, annál nagyobb lesz a csoport kohéziója; ugyanakkor minél nagyobb a csoport kohéziója, annál nagyobb lesz annak valószínűsége, hogy tagjai hasonlóképpen értelmezik a valóságot.

Amikor emberek egy halmazát szegregáljuk, ilyen-olyan okok miatt elkülönítjük magunktól, e csoport tagjai magukra maradnak, érzik a határokat és nincs más lehetőségük, mint egymásra számítani. Amikor nincs kiút, az emberek e halmazon belül kölcsönösen függenek egymástól. A halmaz lassan csoporttá válik, ahogy a benne lévők tagjaivá válnak, bevonódnak 
a csoport létébe, megérzik ezt az egymásra utaltságot. Minél erősebb a csoport körbehatárolása, annál kevesebb információhoz jutnak kívülröl, amit beépíthetnének saját világukba, annál kevesebbet tudnak a kinti tartalmakról, annál nagyobb a lehetősége, hogy saját reprezentációik másképp képezik le azt az egyébként is másmilyen valóságot, amiben élnek.

Amikor egy Pécs város szélén lévő szegregátumban élő gyerekeket megkérdeztem arról, mi szeretnének lenni majd felnőtt korukban, egyik gyerek se tudott odáig álmodni, hogy akár fizikus, csillagász vagy közgazdász is lehetne, és nem azért, mert a képességeik hiányoztak volna hozzá.

$\mathrm{Az}$, hogy hogyan gondolkodunk, meghatározza, kik is vagyunk. Az, hogy kik vagyunk, befolyásolja, hogyan gondolkodunk. Az egyik oldalról a reprezentációk mint a kollektív tudás produktumai lehetővé teszik, hogy különbséget tegyünk egy kontextusban élő különböző csoportok között. A másik oldalról mind a személyes, mind a szociális identitást közvetítik számunkra, így az egyének és a csoportok önmagukat igazolják, határaikat jelzik.

A reprezentációk magyarázó funkciója meghatározza a társadalmi élet mindennapi viselkedéseinek és szokásainak lehetséges okait és magyarázatait. Egy szociális reprezentáció vizsgálatában elsődlegessé válik, hogy megértsük az egyének kapcsolatainak természetét, az adoptált társadalmi szokásokat és a csoportokban és csoportok közötti viszonyok magyarázatát (Bonardi és Roussiau, 1999).

Mennyire befolyásolja azt, hogyan gondolkodunk a munkáról, ha azokat a napokat, amikor nem dolgozunk, szabadságnak nevezzük a magyar nyelvben? Ha Magyarországra nyitott és befogadó társadalomként gondolunk, mennyire fér bele a kisebbségek és másságok megvetése ebbe a képbe? És ha büszkék vagyunk magyarságunkra és úgy gondoljuk, hogy a történelem során mások áldozatai voltunk, mennyire érezhetjük magunkat sértve és e sérelemtöl felhatalmazva arra, hogy másokat, akiktöl fenyegetve érezzük magunkat, persze erönk függvényében, elnyomjunk?

A szociális reprezentációk alapvető funkciója tehát az újjal, ismeretlennel és így veszélyessel való kollektív megküzdés (Moscovici, 1973). Wagner és mtsai (2002) ezt a mindennapi 
élet szimbolikus megküzdésével integrálják. Hipotézisük szerint nemcsak a dolgok új és ismeretlen oldala motiválja az embereket a tudásra, a jelentéstulajdonításra, hanem a mindennapi diskurzusban való részvétel is. Minél jobban foglalkoztat egy csoportot valami, tagjai annál hajlamosabbak lesznek az információ beszerzésére, az adott dologról való tudás elméIyítésére. Egy szociális reprezentáció kialakulásában nagyon fontos az általa betölthető funkciók mennyisége.

Ha a környezetemben mindenki a Trónok Harcáról beszél, nyilvánvaló, hogy el fogom olvasni, meg fogom nézni a sorozatot, de legalább is valami gyors infót szerzek, hogy tudjam, miröl is van szó körülöttem.

\section{A szociális reprezentáció folyamatai}

Két folyamat mentén jön létre a szociális reprezentáció (Moscovici, 1984): a tárgyiasítás és a lehorgonyzás mentén, amelyek egyszerre mutatnak rá a reprezentációk kialakulásának egyéni, pszichikus munkájára és a kultúra (ki)alakulására, azaz a csoportok sajátos valóságértelmezésére.

\section{A lehorgonyzás folyamata}

A lehorgonyzás folyamatában az újnak, ismeretlennek, zavarónak tartott entitásokat a már ismert reprezentációk rendszerébe integráljuk, miközben jelentésük létrejön (Moscovici, 1984). A már létező rendszer értékkel telített kategóriák és jelentések hálója (Abric, 1996; Doise és mtsai, 1999; Spini és Doise, 1998). Először lehorgonyozzuk a már meglévő reprezentációink közé ezt az új és ismeretlen dolgot. Hasonlóságok és különbségek mentén feltérképezzük a helyét e rendszerben, meghatározzuk kapcsolatait a már kialakult reprezentációinkkal. Ebben a folyamatban az egész reprezentációs háló újraszerveződik. A lehorgonyzás folyamata két egymással kölcsönös viszonyban álló alfolyamat eredménye: a megnevezésé és az osztályozásé.

A megnevezés folyamatában a számunkra ismeretlen entitást névvel látjuk el. A név nemcsak egy címke, amellyel a megnevezett dolog identifikálható, hanem a nyelvi kategóriák- 
ban betöltött pozícióját jelöli, meghatározza a tárgy más reprezentációkkal való viszonyát.

A néger, nigger szavak, nemcsak a fekete börszínt jelentették, hanem egy alsóbbrendünek, megvetettnek tekintett embercsoportot jelöltek. Ezt a megnevezést felváltotta a fekete (black). A csoportok közti különbség még mindig a börszínre, a biológiai másságra helyezte a hangsúlyt. Az afroamerikai politikailag felülről bevezetett terminus e biológiai különbségtételt és mögöttes jelentéseit úgy próbálta felülírni, hogy a csoportokat kulturális eredetük (afro-, ázsiai, európai stb.) és közös identitásuk (mind amerikaiak vagyunk) mentén határozta meg. Az afroamerikai megnevezés bevezetése nemcsak kisebb elöítéletességet eredményezett, hanem a csoportról való vélekedést tartalmában változtatta meg (Philogène, 1994).

Az osztályozás folyamata alatt az ismeretlen tárgyat öszszehasonlítjuk már létező kategóriák prototípusaival. Ebben az esetben vagy általánosítunk vagy partikularizálunk. Amikor általánosítunk, csökkentjük a prototípusok és az ismeretlen tárgy közötti távolságot, nem a különbségeket, hanem azokat a dimenziókat részesítjük előnyben, amelyek a hasonlóságot határozzák meg. A partikularizáció folyamata alatt a figyelem a másságra, a különbségekre irányul, azokat az összehasonlítási dimenziókat részesítjük tehát előnyben, amelyek lehetővé teszik az ismeretlen dolog megkülönböztetését a már létező kategóriák prototípusaitól (Moscovici, 1984).

Vegyünk egy nagyon egyszerü példát. Amikor azt próbáljuk elmondani másoknak, mi az a moussaka, a következő leírást használhatjuk: a görögök egy népi étele, olyan, mint nálunk a rakott krumpli (általánosítás), csak a tojás helyett padlizsán van, a tejföl helyett darált hús (partikularizálás). Amikor valami ismeretlennel találkozunk, kategóriák mentén való lehorgonyzását gyakran az „olyan, mint” és az „abban más, hogy” szavak segítségével tesszük.

Doise (1992) három különböző lehorgonyzási folyamatot különböztet meg. A pszichológiai lehorgonyzás a reprezentációt az általános hiedelmek és értékek közé vetíti, azaz konkrét vélekedésekhez általános tudásformákat rendel. A szociológiai lehorgonyzás egyesíti a reprezentációt egy társadalmi csoporttal. A pszichoszociális lehorgonyzás a társadalmi dinamikákra 
és a szociokognitív múködésre épül, ilyenkor a reprezentáció szabályozása az egyén identitásának dinamikáitól függ.

\section{A tárgyiasítás folyamata}

A tárgyiasítás alatt az absztrakt fogalmak konkrét tárgyakká alakulnak. Az egyén egy társadalmi tárgy reprezentációjának folyamata alatt választhat a társadalmi térben elérhető információk közül, előnyben részesít néhányat és figyelmen kívül hagyhat másokat. Ezeket aszerint szelektálja, mennyire ismerősek és konkrétak. Ezek az információk elősegítik a tárgy materializálódását, és ennek következtében, akkor is, ha leegyszerúsítik, az adott tárgy megértését, fontosak lesznek az egyén számára és a „figuratív mag” részeivé válnak.

A „figuratív magban” találhatjuk meg a reprezentáció esszenciális elemeit (Abric, 1984; 2001). A tárgyiasítás végeredménye pedig egy kép, metafora vagy figura, amely az új jelenséget képviseli és ettől kezdve referenciakeretet nyújt a beérkező új információk integrálásánál. A tárgyiasítás elemeinek kiválasztása nem véletlenszerü, hanem a társadalmi hovatartozás sajátosságával kapcsolatban történik. Nem az abszolút igazságra és a pontosságra törekszik, hanem a hihetőségre (Wagner és mtsai, 1999). Billig szerint (1988) míg a lehorgonyzás egy általános folyamat, a tárgyiasítás sajátos, nem minden reprezentációnál jön létre. Moscovici (Moscovici és Hewstone, 1983:112) a tárgyiasítás alfolyamataiként az ábrázolást, a megszemélyesitést és az ontologizálást határozta meg. Az ábrázolás folyamata alatt az absztrakt fogalom egy metaforikus képpé szerveződik (a kreativitás például egy vulkáni kitörés képében), a megszemélyesítés folyamata alatt a fogalomhoz egy híres személyiség képe társul (a pszichoanalízist gyakran Freud képével azonosítjuk), míg az ontologizálás alatt a fogalom valóssá válik, fizikai tulajdonságokkal ruházódik fel (az agy mint egy adatokat feldolgozó komputer). A tárgyiasított fogalom a mindennapi diskurzus részeként rögzül.

A lehorgonyzás és a tárgyiasítás folyamatait a reprezentáció naturalizálása követi (Moscovici, 1981; Philogène, 1994). A naturalizáció folyamata alatt a tárgyiasított reprezentáció képe kognitív sémából konkrét valósággá, társadalmi kategóriává vá- 
lik, és el kezdi szabályozni a konkrét történéseket. A tudást el kezdjük használni, mint szemüveget a valóság értelmezésében.

\section{A szociális reprezentáció struktúrája}

A szociális reprezentációk strukturalista megközelítése az Aixen-Provence-i iskola nevéhez füződik (Abric, 1993, 1994a; 1994b; Flament, 1994, Guimelli, 1994; Moliner, 1995). A francia szerzők egy kettős rendszer múködéséhez kapcsolják a szociális reprezentációk szerveződését. A mélyre nyúló történelmi és társadalmi gyökerekkel rendelkező központi rendszer vagy figuratív mag a reprezentáció kollektív alapjait képezi; ez a reprezentáció legjobban konszenzuális része, homogén az egész csoport számára. A rugalmas periferikus rendszer az egyéni különbségeket és a kontextusbeli változásokat tükrözi; lehetővé teszi, hogy a reprezentáció alkalmazkodjon a külső kontextusbeli változásokhoz, olyan információkat épít magába, amelyek tükrözik a kontextuális változásokat vagy az egyéni különbségeket ebben a tudásban, mégis még nem annyira jelentősek, hogy a reprezentáció egésze megváltozzon. A társadalmi heterogeneitást tehát ezek a tartalmi különbségek tükrözik. A periferikus rendszer a konkrét valóság és a reprezentáció magja közti felület.

\section{1. ábra. A szociális reprezentáció struktúrája}

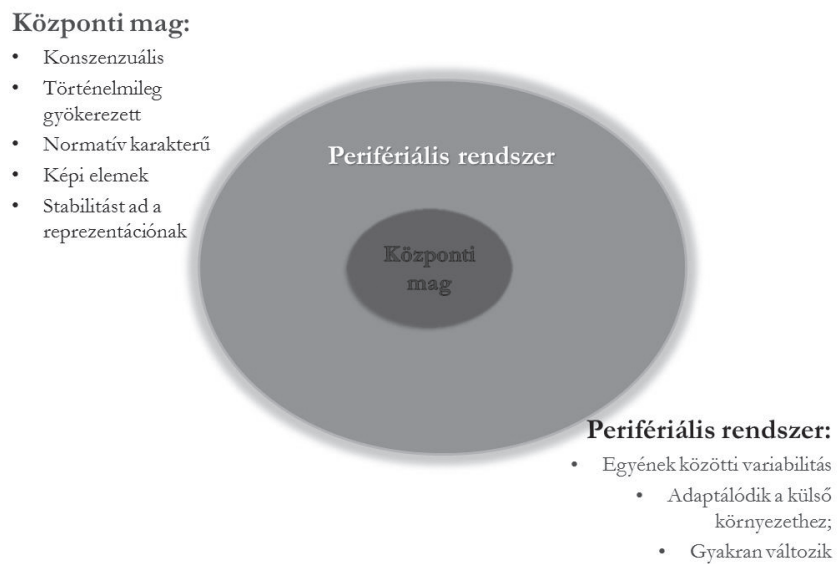


Abric (1994a) a figuratív mag elemeinek normatív, a periferikus rendszer elemeinek funkcionális karakterét emeli ki. Míg egy elem normativitás foka az egész társadalmi csoport kollektív értékeitől függ, funkcionalitása az egyén társas cselekvéseitől, a mindennapi életben való részvételétől.

A központi rendszer vagy figuratív mag három funkciót tölt be: stabilizál, mivel a konszenzuális részt tartalmazza stabilitást és koherenciát nyújt a reprezentációnak; alkot, megszabja a reprezentáció tartalmát és a lehetséges változásokat; és szervez, mivel meghatározza a reprezentáció elemeinek lehetséges kapcsolatait. Flament idézve „a központi mag nem egy egyszerű szervező elv, hanem egy struktúra (a szó szoros értelmében), ami az egész reprezentációnak jelentést tulajdonít, beleértve a változásra hajlamos elemeket is" (1994:104). A központi mag elemeinek sajátosságát mennyiségi (a konszenzus mértékétől függő kvantitatív hangsúlyosság) és minőségi (az elem szükségességétől függő kvalitatív követelmény) mutatókkal lehet meghatározni.

A periferikus rendszernek úgyszintén három funkciója van: konkretizál, szabályoz és lehetővé teszi az egyéni változatosságot. Lefordítja a központi mag elemeit viselkedéssorra, a kontingens külső helyzethez adaptálja a mag sajátosságait, így a külső hatásoktól megvédi a mag jelentőségét, és teret ad az egyéni tapasztalás és az egyén saját élményének reprezentációba való integrálására.

Ebben a megközelítésben minden szociális reprezentáció rendelkezik időben és a külső nyomásra rezisztens elemekkel. Ezek az elemek adják meg a reprezentáció folyamatosságát és konzisztenciáját. Ugyanakkor a periferikus elemek átalakulhatnak a társadalmi kommunikáció során, tükrözve így a társas terek variabilitását és különbségeit. A strukturalista megközelítés a reprezentációk átalakulásának lehetőségét a társadalmi szokások és cselekvések átalakulásában látja. Flament szerint (1994) egy reprezentáció átalakulása attól függ, mennyire észleljük visszafordíthatónak az új szokások és cselekvések által létrejött helyzetet. Ha a csoport ideiglenesnek, bizonytalannak és visszafordíthatónak észleli a helyzetet, és abban a hitben él, hogy visszatérnek a régi szokások és társadalmi cselekvések, csak a reprezentáció periferikus elemei fognak megváltozni. 
Ha az új helyzetet a csoport visszafordíthatatlannak értékeli, a régeikkel ellenkező új szokások sokkal mélyebb átalakulást fognak előidézni, akár a reprezentáció magja is érintetté válhat. Abric a reprezentáció három lehetséges átalakulását feltételezi: a rezisztens átalakulásban a régiekkel ellentmondó új szokásokat magába szívja a védekező mechanizmusként múködő periferikus rendszer. Ebben az esetben, Flament szerint (1994) a periferikus elemek között ismeretlen sémák is jelentkezhetnek, amelyek emlékeztetnek az elfogadottra, jelzik az idegen elemeket, megjelölik a kettő közötti ellentmondásokat és megpróbálják ezeket racionalizálni. A progresszív átalakulás esetében az új szokások nem állnak teljes ellentmondásban a régiekkel. A változás lassan jön létre, a központi mag osztódása nélkül. Az új szokások által aktivált sémák folyamatosan integrálódnak a régi elemek közé, mielőtt végleg felváltanák őket. A brutális átalakulás során az új szokások kétségbe vonják a reprezentáció központi magjának jelentőségét. Ezekben az esetekben - ha az új szokások fontossá válnak, fennmaradnak és egy visszafordíthatatlan helyzetet idéznek elő - a központi mag teljes és direkt átalakulása megy végbe.

\section{Az elmélet történelmi háttere}

Moscovici 1961-ben prezentálta La Psychanalyse, son image et son public (A pszichoanalízis, képe és közönsége) címú doktori tézisét, melyben a pszichoanalízis leképződését vizsgálta a francia társadalomban: hogyan és milyen átalakuláson keresztül kerültek a köztudatba a pszichoanalitikus elmélet fogalmai és gondolatai, és a különböző ideológiai háttérrel rendelkező kommunikációs rendszerek, adott esetben az újságok, hogyan közvetítették ezeket a jelentésbeli transzformációkat.

A kutatás első részében Moscovici a párizsi lakosság reprezentatív mintáján a pszichoanalízissel kapcsolatos tudásukról és attitűdjükről végzett felmérést. Eredményei kimutatták, hogy annak ellenére, hogy az ötvenes évek végére a pszichoanalízis jelentősen behatolt a francia mindennapi életbe, ezeknek a tudásformáknak sajátos szerveződései jelentkeztek az embereknél és az elmélet nem minden aspektusát ölelték fel (László, 
2005). A mindennapi tudás részeivé váltak olyan fogalmak, mint a tudatalatti, a represszió, a terápia és a komplexusok, míg más fogalmak, mint például a libidó és a szexualitás nem.

Moscovici a vizsgálat második részében a pszichoanalízisről 1952 és 1956 között három különböző újságtípusban megjelent cikkeket vetette tartalomelemzés alá: a (1) nagy példányszámban megjelenő népszerü újságok, (2) a katolikus újságok és (3) a kommunista lapok cikkeit. Eredményként azt kapta, hogy a különböző lapok különböző kommunikációs stílusokat alkalmaznak, attól függően, mennyire képesek a pszichoanalízis elméleti kereteit saját ideológiai felfogásukba integrálni. A népszerű lapok a diffúzió kommunikatív stílusával éltek, a pszichoanalízisről különböző, nem összehangolt és gyakran ellentmondó információkat közöltek, egyszerre használták az iróniát, a komoly információátadást és a kritikus szemlélet eszközeit. A katolikus újságok másképp kommunikáltak. Voltak olyan tudásegységek, amelyek beleillettek saját ideológiai rendszerükbe, például a spiritualizmus vagy a gyónással párhuzamba hozható terápiás ülés, ugyanakkor azokról az elemekről nem írtak, amelyek saját gondolati rendszerükbe nem illeszkedtek, mint a libidó vagy a szexualitás. Ezt a fajta kommunikációs stílust Moscovici propagációnak nevezte el. Végül a kommunista lapok - individualista megközelítése miatt - a pszichoanalízis elméletét szembeállították a sajátjukkal. A pszichoanalízisről szóló cikkek tehát az elmélet kritikájára épültek, ellenvéleményként fogalmazódtak meg, a róluk szóló kommunikáció a propaganda stílusával élt.

Moscovici szerint a különböző kommunikációs stílusok, a diffúzió, propagáció és propaganda a vélemény, az attitűd és a sztereotípia sajátos tudásformáit hozták létre (Moscovici, 1961). A vélemény egy pró és kontra felsorakoztatására épülő tudás, az attitűd egy identitáshoz köthető explicit viszonyulás a tudás tárgyához, végül a sztereotípia a releváns másikról alkotott sematikus tudás. Moscovici tézise nemcsak a társadalmi kontextust kötötte össze a tudás szerveződésével, hanem a tudás szerveződését is a kommunikációval. 


\begin{tabular}{|l|l|l|l|}
\hline $\begin{array}{l}\text { KOMMUNIKÁCIÓS } \\
\text { FORMÁK }\end{array}$ & $\begin{array}{l}\text { Nagy példány- } \\
\text { számú népszerü } \\
\text { újságok }\end{array}$ & $\begin{array}{l}\text { Katolikus } \\
\text { újságok }\end{array}$ & $\begin{array}{l}\text { Kommunista } \\
\text { lapok }\end{array}$ \\
\hline $\begin{array}{l}\text { KOMMUNIKÁCIÓS } \\
\text { STíLUSOK }\end{array}$ & diffúzió & propagáció & propaganda \\
\hline TUDÁSFORMÁK & vélemény & attitüd & sztereotípia \\
\hline
\end{tabular}

Ebben a már klasszikusnak tekintett tanulmányban Moscovici az egész tudományos világban interdiszciplináris szinten elterjedt és elismert szociális reprezentáció elmélet alapköveit rakta le.

Jovchelovitch (2002) szerint Moscovici tanulmányával egy a 20. század elején született tudományos vitában foglalt állást, melynek tárgya a tudás és a társadalmi kontextus közötti kapcsolat volt, és az, hogy ez a kapcsolat miként alakítja a tudás racionalitását. Moscovici a reprezentációs mező sokszínűségéről kapott eredményének értelmezésében a "kognitiv polifázia” fogalmát használta, mellyel azt próbálta megmagyarázni, miként élnek együtt egyszerre különböző, gyakran össze se hangolható tudások egy egyénben vagy egy csoportban. Hipotézise szerint ezek a dinamikusan együtt létező tudásmodalitások az egyén és társadalmi kontextusa közötti többfajta sajátos kapcsolatnak felelnek meg. Így ezek az egyszerre létező tudásformák különböző funkciókat töltenek be.

Minden új gondolat egy régi újragondolása és meghaladása. Így ahhoz, hogy megértsük, miként járult hozzá Moscovici a tudás és a kontextus kapcsolatáról szóló tudományos vitához, fontosnak tartom, hogy kitekintsünk azokra az elméleti megfontolásokra, amelyekre munkája épült: a szociológia területén Durkheim kollektív reprezentáció fogalmára, az antropológia területén Lévy-Bruhl primitív és civilizált gondolkodás magyarázatára és Piaget és Vigotszkij a tudás társadalmi természetével kapcsolatos pszichológiai megközelítéseire.

Moscovici elméleti megfontolásaiban Durkheim kollektív és egyéni reprezentáció fogalmaiból indul ki. Durkheim szerint (1898) az egyéni reprezentációk a pszichológia, a kollektív reprezentációk a szociológia tárgyát kell, hogy alkossák, mivel a "társadalmi tények" nem magyarázhatóak a pszichológia keretein belül. Ahogy az egyéni reprezentációk függetlenek az „idegi központok állapotától”, úgy a kollektív reprezentáci- 
ók is függetlenek az egyénektől. Az egyéni tudaton kívül állnak, és nem az egyének, hanem azok csoportjai hozzák létre. Durkheim számára, a kollektív reprezentációk kollektívek, mert a kollektivitás hozza őket létre, a kollektivitás a tárgyuk és egy adott kollektivitás egyénei számára közösek és homogének. A kollektív reprezentációk egy társadalmi valóságot képeznek, melybe különböző intellektuális formák tartoznak, mint a vallás, a morál, a jog, a mítosz és a tudomány. Farr szerint (1998) Durkheim, azáltal, hogy különbséget tesz egyéni és kollektív reprezentáció között, Wundt egyéni és szociálpszichológia (Volkerpsychologie) felosztását idézi, melyben e második célja a kollektív tapasztalások, mint a nyelv, a mítosz, a vallás, a mágia és hasonló jelenségek tanulmányozása, amelyeket nem lehet az egyéni tudat szintjén megmagyarázni.

Moscovici a kollektív reprezentáció fogalmát felcseréli a szociális reprezentáció fogalmára. A szociális nemcsak megnevezésbeli különbség, hanem azoknak a fó elméleti reflexióknak a hangsúlyozása, amelyek megkülönböztetik a durkheimi reprezentáció fogalmától. A reprezentáció szociális karaktere egyszerre törli el (a) az egyéni és a kollektív szint közti különbséget, (b) mutat rá kommunikációba ágyazottságára és így dinamikus jellegére, (3) illetve a különböző dimenziók mentén létező társadalmi rétegződésre (gazdasági, etnikai stb.). Ez a rétegződés a hovatartozás és identifikáció pszichológiai folyamatait eredményezi, amelyek mentén a reprezentációk (tudástartalmak) töredezettsége és/vagy a konszenzus minősége érhető utol.

Moscovici (1988) a reprezentációk társas karakterére utalva hegemonikus, emancipált és polemikus reprezentációkról beszél. E típusok közötti különbség a kollektív és szociális reprezentáció közötti fogalmi átmenetet hangsúlyozza. A szerző hegemonikus reprezentációk alatt olyan reprezentációkat ért, amelyek jelentése erősen konszenzuális, közös egy adott csoport (pl. nemzet, társadalmi osztály stb.) minden tagja számára. Ez a típusa a reprezentációknak - a durkheimi reprezentációkhoz hasonlóan - minden szimbolikus és affektív cselekvést irányít, egységes és kényszerítő, jelentésének stabilitását és homogeneitását tükrözve. Ezzel ellentétben, az emancipált reprezentációk egy kontextusban élő többé-kevésbé érintkező 
csoportok különböző reprezentációi. A különbség a csoportok számára elérhető új információk mennyiségétől és minőségétől, a lehetséges kommunikációs csatornák hozzáférésétől és használatától függ, és attól, mennyire fontos és funkcionális az adott reprezentáció a különböző csoportok számára. Ezek a reprezentációk többé-kevésbé függetlenek egymástól, inkább kiegészítik egymást, mivel a csoportok között elcserélt és megosztott különböző értelmezésekből és szimbólumokból jönnek létre. Végül a polemikus reprezentációk egy társadalmi konfliktusra épülnek. Csoportok közötti antagonisztikus kapcsolatokhoz tartoznak, lényegük egymás kölcsönös kizárása. Értelmezésük a konfliktushelyzethez és a csoportok közötti harchoz kötődik, valós vagy elképzelt dialógusban fejeződnek ki. Az eltérő tudások itt a különböző csoportidentitások közötti konfliktusból eredeztethetőek. Ha te „A" csoportba tartozol, én meg „B” csoportba, és a két csoport között antagonizmus vagy konfliktus (akkor is, ha csak szimbolikus konfliktus) van, akkor ha te arról a dologról ezt gondolod, én biztos, hogy mást fogok gondolni.

Lévy-Bruhl (1910/1985) is foglalkozik a kollektív reprezentáció fogalmával. Szerinte egy társadalomban megtalálható domináns reprezentációk az egyének számára kényszerítő jellegúek, mivel meghatározzák azt a referenciakeretet, amit az egyénnek használnia kell, hogy magáról gondolkozzon és kifejezze érzelmeit. Különböző társadalmakban különböző kollektív reprezentációk jönnek létre, így minden mentalitás típusnak megfeleltethető egy társadalomtípus - saját intézményeivel és szokásaival. Lévy-Bruhl (1975) az emberi társadalmak két prototípusát különbözteti meg sematikusan: a primitív és a civilizált társadalmat, melyeket különböző emberi gondolkodás jellemez. A primitív gondolkodás nem értékelés, hanem minőségében más működésmód; természetfeletti elemeket követ, gyakran inkoherens, az ellentmondás elvét nem ismeri, míg a civilizált gondolkodás koherens és racionális, az ellentmondás és a logikai gondolkodás elveire épül. Moscovici szerint (1998) Lévy-Bruhl ezen elméleti konstrukciója a reprezentációk affektív és intellektuális struktúráit szabadabban hagyja és - akkoriban radikális feltevés - a gondolkodás kulturális formáinak nem általánosíthatóságát feltételezi. 
Piaget a húszas években (1926) a fejlődéslélektan keretein belül újraértelmezi Lévy-Bruhl primitív és civilizált gondolkodás fogalmát, azzal a céllal, hogy megmagyarázza, miként válik a primitív gondolkodás tudományossá. Munkájában a figyelem a reprezentáció kollektív karakteréről dinamikájára irányul. Piaget számára a kisgyerekek gondolkodása a nagyokhoz képest nem alacsonyabb rendű, hanem egyszerűen csak más. A gyerekek és a felnőttek világa közti különbséget a reprezentációk teszik lehetővé: a társadalmi részvétel, az interakciókban leosztott szerepek minőségi különbségei a gondolkodás minőségi különbségeit tükrözik vissza, míg a reprezentáció tartalma egyéni marad. Piaget érvelése szerint, ahogy a primitív gondolkodásban, úgy a gyermeki gondolkodásban is a gondolkodási folyamatoknak és a környezet aspektusainak fúziói nyilvánulnak meg. Piaget elméletében is (1972) tehát a szociális interakciók elsődleges szerepet játszanak a logika kialakulásában; amit vizsgálni kell, hogy milyen típusú interakciók milyen típusú logikát generálnak. Jó példa rá az a vizsgálat, melyben a szerző azt tanulmányozta, hogy a kooperáció és a kényszerítés szociális interakciói milyen gondolkodástípusokat hoznak létre (Piaget, 1972, id. Jovchelovitch, 2002, id. Pléh, 1996). Moscovici szerint Piaget elmélete a reprezentáció pszichikus oldalának sajátosságaival foglalkozik.

Ahogy Piaget tanulmányaiban azzal foglalkozik, hogy a társadalom hogyan plazmálja a gyermek logikai struktúráit, Vigosztkij azt vizsgálja, ahogy különböző típusú kapcsolatok különböző tudásformákhoz vezetnek. A húszas években Üzbegisztán és Kirgizisztán parasztjaival folytatott kultúrközi vizsgálatokban Vigotszkij és tanítványa, Lurija (Vigotszkij és Lurija, 1993; Lurija, 1979) ugyanarra a következtetésre jutottak: a tudás és a mentalitás mélyen gyökereznek saját társadalmi kontextusukban.

Jovchelovitch (2002) rámutat arra, hogy ezek az elméletek ugyan elfogadják azt az elgondolást, miszerint a tudás szerveződése a társadalmi kontextustól függ, és így elismerik a különböző tudásformák létezését, különböznek abban, hogy hogyan magyarázzák e tudásformák közti különbséget, azaz milyen kritériumok mentén hasonlítják össze őket és mi alapján döntik el, hogy egy gondolati szerveződés felsőbb vagy 
alsóbb rendű. Többé-kevésbé explicit módon mind a négy elméleti megközelítésben a szerzők a fejlődéssel magyarázzák e különbséget; azt felételezik, hogy egy tradícióktól mentes és az érvelésre alapozott társadalmi élet teszi lehetővé a racionalitás legmagasabb fokát és a világ mélyebb szintű megértését. Lévy-Bruhl az egyetlen, aki számára a logika egy rugalmas kategória, és így a különböző létező logikák nem az egyetlen és helyes logika fejletlen állapotai, hanem minden tudásforma egy önmagában múködő tudás. Többek között a szerző azt is megfogalmazza, hogy ezek a különböző logikák nem zárják ki egymást a priori és nem feltétlenül helyettesítik egymást, mivel egyszerre több funkciót is betölthetnek.

Vigotszkij egyetért Lévy-Bruhl azon állításaival, melyek szerint a tudás transzformációja nem folyamatos, egy adott társadalmi kontextusban egyszerre különböző tudástartalmak létezhetnek, és hogy megértsük ezeket a különböző tartalmakat, szükségünk van kontextusukban tanulmányozni az általuk betöltött funkciókkal együtt (Vigotszkij és Lurija, 1993). Moscovici kognitív polifázia fogalma ennek az elgondolásnak a kifejtése, rámutat arra a tényre, hogy nemcsak a társadalmi helyzetek és tudástípusok közötti kapcsolatot szükséges vizsgálni, hanem ezeknek a tudástartalmaknak az átalakulását és egyidejű fennállását is.

\section{A szociális reprezentáció dinamikája: kommunikáció és konszenzus}

A szociális reprezentáció mint metaelmélet feloldani látszik az egyénről és a társadalomról szóló évezredes vitát - kölcsönös kapcsolatot teremtve a kettő között. Az elmélet szerint az egyén pszichológiai folyamatai elválaszthatatlanok tudásának tartalmától, azaz reprezentációitól. Ugyanakkor ezek a tartalmak a kommunikáción és az interakción keresztül a társadalmi kontextusban jönnek létre, szerveződnek és maradnak fenn. Ebben az interszubjektív térben egyén és társadalom kölcsönösen hatnak egymásra. Míg a társadalom már létező jelentéseket kínál, kötelezve az egyént azok használatára, az egyén megkérdőjelezésükkel változásokat indíthat be ezekben a kokonstruált, másokkal közösen létrehozott tartalmakban. 
Ahogy barátainkkal, családtagjainkkal, munkatársainkkal elvitatkozunk a politikán vagy egy nemrég olvasott könyv tartalmán vagy azon, mit ért a másik szerelmen, szereteten, munkán, háborún, szegénységen, vagy hogyan is értelmezzük azt a jelenetet, amit tegnap láttunk az utcán, a tévében vagy épp velünk történt - ezek azok a helyzetek, amelyekben tetten érhetö a közös tudás alkotása, a szociális konstrukció. A sok időt együtt töltő baráti közösségek; az egy nyelvet beszélö emberek csoportja, akik ugyanazokat a tévé- és rádiómüsorokat nézik, hallgatják és ugyanazokon a híradókon keresztüli figyelik a világot; a szegregált közösségek, ahol szoros egymásrautaltságban együtt élnek az emberek; a cyberspace adatbüvészeinek közössége - ezek azok a rétegek, csoportok, amelyek közösen használt kommunikációs síkjaikon keresztül hasonló tartalmakról gondolkoznak el, azokat megvitatják, tágítják vagy szükítik a mögöttes tartalmakat, és ezáltal egyre mélyebb, bár soha se teljes konszenzusban gondolkodnak fogalmakról, absztrakt és konkrét tárgyakról, emberekröl és azok csoportjairól. Hasonlóan szemlélik a világot.

A reprezentációk tartalmának (néha tudatos, explicit, bújtatott, láthatatlan, nem megfogalmazott, nem intencionális) konszenzusra törekvő közös alkotása (egymás valamilyen mértékű megértése) egymásnak feszülő információegységek, érvek és ellenérvek, szempontok ütköztetése mentén történik. $A$ konfliktusra és feszültségre alapozott kommunikáció dialektikus és dialogikus karaktere teszi lehetővé ezeknek a tartalmaknak a ki- és átalakulását (Markova, 2000). Markova Bakhtin (1981) dialogikus fogalmára hivatkozik, aki szerint a dialogikus egy közösség hangjainak polifóniájában rejlik, melynek célja nem egymás kiegészítése, hanem, ellenkezőleg, a másság folytonosságának megerősítése. Ugyanakkor fontos kiemelni, hogy a szociális reprezentációk kommunikációja nemcsak azok átalakulását teszi lehetővé, hanem terjedését és megosztását. A többé-kevésbé megosztott tartalmak, a konszenzus mértéke csökkenti az interakciók bizonytalanságát (Moscovici, 1981).

A dialogizmus létrejöttének feltétele a teljes konszenzus hiánya. A dialogikus tudás mások gondolatai, értelmezései felé irányul. Azokkal összefüggésben fogalmazódik meg, kiegészítve, elmélyítve, részben vagy egészben vitatva, értelmezve, 
átértelmezve, saját sémákba illesztve. Minden jel, szöveg, múvészeti alkotás, zenei darab, koherens és komplex történelmi értelmezés, tudományos mű önmagába zár dialogikus jellegzetességeket: mások elméje és gondolatai felé irányul. Az emberi dialógus a világfelfogás dialektikáját magyarázza.

A hegeli dialektika szerint minden élő jelenség egy belső feszültséggel rendelkezik, egymásnak ellentmondásos elemeket hordoz. A szociális reprezentáció elmélete ezeket a reprezentációkat átszövő alapvető feszültségpárokat themata-nak nevezi, mint például a férfi-női, kicsi-nagy, érzelmi-gondolati stb. Az elme dialektikus múködését generáló ellentétpárokat a természetben és a társadalmi valóságban egyaránt megtalálhatjuk, ezek köré szerveződnek az interakcióink, a kommunikációnk, a dialógus, ezekre a már meglévő feszültségpárokra épül a változás lehetősége is.

Ahogy Moscovici bemutatatta pszichoanalízisről szóló kutatásában, a különböző kommunikációs síkok a tartalmakat másképp közvetítik számunkra. A kommunikáció és a tudás egymással való és egymástól elválaszthatatlan összefonódását jól ábrázolja az orális kultúrák kommunikációjának elemzése, talán azért, mert távolabb van tőlünk és így messzebbről szemlélhetjük.

Az orális kultúrákban a fö érzékszerv a szem helyett a fül, az emlékezés a legfontosabb pszichológiai folyamat, a gondolat helyzetfüggő, a gondolat szubsztanciáját a közmondások és maximák kommunikációs síkjai közvetítik a legjobban. A kommunikációban elsődlegessé válik a ritmusosság és a prózaiság, a kompetitiv stílus, ami lehetővé teszi az érzelmi telítődést és az ismétlések áradatát. A kommunikáció befogadása enfatikus és a részvételre kötelez (Ong, 1986; McLuhan, 1976). Az így közvetített tudás homeosztatikus, azt zárja magába, aminek itt és most, a jelenben fontos és értelme van.

Lévy-Strauss szerint (1962) azokban a kultúrákban született meg az írás, amelyekben gazdasági és társadalmi változások miatt szükség volt az információ kihelyezésére. A szerző különbséget tesz hideg és meleg kultúrák között, a különbség a gazdasági és/vagy társadalmi átalakulás felismerése és az arra adott reakció vagy épp ellenkezőleg a kultúra és az emlékezet lefagyasztása, a fenyegetettségre adott válaszreakció- 
ként. Eszerint nemcsak a tartalmak, a szociális reprezentációk, hanem a kommunikációs síkok használata is társadalmi funkciójukhoz köthető.

Potter és Litton (1985) az elmélet kritikusaiként eufemizmusnak definiálják a csoporthatárok és a konszenzuális tudás adott emberek közt megosztott reprezentációkat. Azt az elméleti állítást kritizálják, miszerint a csoportok közötti különbségeket az eltérő reprezentációk tükrözik, míg a csoportok csoportokként identifikálhatóak, mert eltérő reprezentációik vannak. A szerzők szerint ez az ördögi kör a nem kidolgozott konszenzus fogalmából ered, azt nem igazolja. Szerintük nem lehet a reprezentációkat esszenciájukban a társadalmi csoportokhoz kötni, inkább a nyelvben utolérhető értelmezési repertoárokról beszélhetünk. Bellelli szerint (1994) viszont a reprezentációk szociális/társadalmi csoportokhoz kötött karakterét vélemények egyhangúságaként kezelni korlátolt gondolkodáshoz vezet, mivel a reprezentáció fogalma így csak a gyakoriság és az elterjedés folyamataira redukálódna. Miközben vannak olyan helyzetek, amikor különböző csoportok hasonló tudással rendelkeznek egy adott dologról, vagy egy csoporton belül is nagy a változatosság egy reprezentáció tekintetében, vagy ugyanaz az egyén különböző reprezentációkat aktivál másmás helyzetekben, ahogy azt a fentebb leírt kognitív polifázia fogalmával körvonalaztuk (Fraser, 1994; Mugny és Carugati, 1989, Potter és Litton, 1985).

A csoportokat mint érzelmileg telített kommunikációs hálókat határolhatjuk körül, amelyek lehetővé teszi a jelentések konszenzuális megosztását. Sőt, azok a jelentések válnak majd a kommunikáció tárgyává e csoporton belül, amelyek fontosak a csoport tagjai számára és még nem alakult ki egy többé-kevésbé közös értelmezés az adott jelenségről. Minden ember egyszerre több csoport és társadalmi kategória tagja is, és ez az összetett és többszörös hovatartozás határozza meg saját nézeteit. Így annak függvényében, hogy egy adott társadalmi helyzetben mely identitás aktiválódik erőteljesebben, meghatározza, hogy az adott társadalmi tárgyról alkotott, nem feltétlenül koherensen összehangolt tudásunk mely elemei aktiválódnak. Sőt, minden társadalmi helyzet alkuhelyzet is, egyeztetést és különböző tudások valamekkora összehangolását 
igényli. Minél jobban érzelemmel telített egy csoporttagság, annál jobban fog kihatni egy egyén életére, annál fontosabb lesz az egyén számára a csoport számára közös reprezentációk elfogadása, sajátként való képviselete.

Wagner és Hayes szerint (2005) a konszenzus mértéke funkcionális jellegű, mivel a társadalmi csoportok koordinált interakciók mentén szilárdítják meg önmagukat. Egy társadalmi tér résztvevői például széles mértékben osztják az interakciók szerveződését, ami lehetővé teszi számukra a csoport és intézményei struktúrájának megerősítését. Minden társadalmi csoportnak számolnia kell a lehetséges eltérésekkel, így a konszenzus soha nem lesz teljes, hanem funkcionális. Minősége és mennyisége a tagok saját csoportjuk dinamikájába és szabályaiba vetett hitének függvénye. Így a statisztikai eljárásokban kapott variancia nem 'bias'-ként, hibaként, értelmezendő, hanem a társadalmi rendszerben megjelenő véleménykülönbségek és heterogenitás visszatükröződése. A társadalmi változások pedig ott érhetőek utol, ahol nagy a lehetséges vélemények variabilitása.

\section{Szociális reprezentáció és identitás}

A fent leírtak szerint észlelhetnénk magunkat mint egy a tér és idő koordinátájában elhelyezett pont. A pont lehorgonyzása teszi lehetővé, hogy a világ, benne saját magunk észlelhetővé, valóssá, érthetővé váljon önmagunk számára. Átfordítva, a társadalmi kontextus és történelmi dimenzió meghatározása nyújtja azokat a mentális és társadalmi eszközöket, amelyek filterezik számunkra a valóságot. Mert a valóság egy közvetett valóság, a koordinátában megjelenő pontok szempontokká, referenciapontokká válnak bármilyen kognitiv, érzelmi vagy viselkedésbeli folyamatnál; az észlelésbeli különbségektöl a fizikai és társadalmi tárgyak minimális vagy komplexebb kategorizációján keresztül a használt érték- és normarendszerekig.

Önmagunk szabadsága a társadalmi rendszerbe gyökerezett szerepek kreatív elsajátításában és idővel új szerepek megalkotásában rejlik. Identitásunk egy empirikus folyamat időben folytonos változásaiban jön létre és alakul át. Ugyan- 
akkor identitásunk nem redukálható azokra a belsővé tett szerepekre, amelyeket a mindennapi életben átélt komplex társadalmi interakciók mentén sajátítunk el. Az identitás nem egy „,valami”, ami az ember tulajdona, nem is egy „tárgy”, még ha különleges is, ami elveszthető, megtalálható, másoknak adható vagy örökölhető. Az identitás egy folyamat, pillanatról pillanatra a külső és a belső közti egyeztetésre épül, a legintimebb elemeitől a legkollektívebbekig (Erős, 2001). Önmagunk reprezentációja tehát a Másik reprezentációjával összefüggésben létezik. Tartalommal ruházva fel a Másikat, egy törékeny határt építünk önmagunk és az önmagunkon kívüli közé. Létrehozva olyan társadalmi egységeket, mint mi, ti vagy ők, meghatározzuk az identifikációs folyamatok mentén létrejött kategóriák minőségét, funkcióit és különválasztási kritériumait. A társadalmi kategóriák közti különbségtétel kritériumainak kiválasztása folytonos hatalmi harcok szimbolikus tárgya.

\section{Összegzés}

Ez az elmélet lehetővé teszi, hogy megértsük azt, ahogy emberek - gyerekek, fiatalok, felnőttek egyaránt - viszonyulnak a világukban található dolgokhoz. Csak akkor tudunk bárhogyan is hatni rájuk, ha alapból elfogadjuk és elismerjük e tudásukat, és megértjük miértjét. Másokra gyakorolt hatásunk annak függvénye, mennyire tudjuk az általunk képviselt „újat” úgy átadni, elmondani, kommunikálni, hogy az a sajátjukká váljon, életükben értelmet nyerjen, valóban magukénak tudják és képesek legyenek alkalmazni mindennapjaikban.

\section{Irodalomjegyzék}

Abric, J. C. (2001): A structural approach to social representations. In: Deaux, K. és Philogène. G. (szerk.) Representations of the social: bridging theoretical traditions. Blackwell, Oxford, 42-47.

Abric, J. C: (1996) Specific processes of social representations. Papers on Social representations, Vol. 5, 77-80. 
Abric, J. C. (1984): A theoretical and experimental approach to the study of social representations in a situation of interaction. In: Farr, R. M. és Moscovici, S. (szerk.) Social representations. Cambridge University, Cambridge, 169-183.

Abric, J. C. (1993): Central System, Peripheral system: their funcions and roles in the dynamics of social representations. Papers on Social Representations.

Abric, J. C. (1994a): Les représentations sociales: aspects théorique. In: Abric, J. C. (szerk.) Pratiques sociales et représentations. Presses Universitaire de France, Paris.

Abric, J. C. (1994b): Nature et fonctionnement du noyau central d'une représentation: la représentation sociale de l'entreprise. Paper presented to the II International Conference on Social Representations, Rio de Janeiro, Brazil.

Bakhtin, M. M. (1981): The dialogic immagination. University of Texas Press, Austin, Texas.

Bellelli, G. (1994): Rappresentazioni sociali ed epistemologia naive. In: Bellelli, G. (szerk.) L'altra malattia. Come la società pensa la malattia mentale, Liguori, Napoli.

Billig, M. (1988): Social representations, objectification and anchoring: a rhetorical analysis. Social Behavior, 3, 1-16.

Bonardi, C. és Roussiau, N. (1999): Les representations socials. Dunod, Paris.

Doise, W. (1992): L'ancrage dans les études sur les representations sociales. Bulletin de psychologie, XLV, 405, 189-195.

Doise, W., Spini, D. és Clémence, A. (1999): Human rights studied as social representations in a cross-national context. European Journal of Social Psychology, 29, 1-29.

Durkheim, E. (1898): Représentations individualles et représentations collectives. Rev Métaph Morale VI, 273-302.

Erős Ferenc (2001:) Az identitás labirintusai. Narrativ konstrukciók és identitásstratégiák. Janus/Osiris, Budapest.

Farr, R. M. (1998): From Collective to Social Representations: Aller et Retour. Culture \& Psychology, Vol. 4, No. 3, 275296.

Farr, R. M. és Moscovici, S. (eds.) (1984): Social representations. Cambridge University Press, Cambridge.

Flament, C. (1994): Structure, dynamic et transformation sans rupture d'une représentation sociale. In: Abric, J. C. (ed.) 
Pratiques sociales et représentations. Presses Universitaire de France, Paris.

Fraser, C (1994): Attitudes, social representations and widespread beliefs. Papers on Social Representations, 3 (1), 13-25.

Guimelli, C. (1994): Transformation des représentations sociales, pratiques nouvelles et schèmes cognitifs de base. In: Guimelli, C. (ed.) Structure et transformations des représentations sociales. Neuchatel, Delachaux et Niestlé. Jovchelovitch, S. (1996): In defence of representations. Journal for the Theory of Social Behaviour, 26 (2), 121-135.

Jovchelovitch, S. (2002): Re-thinking the diversity of knowledge: cognitive polyphasia, belief and representation [online]. LSE Research Online, London

László János (2005): A történetek tudománya. Bevezetés a narratív pszichológiába. Új Mandátum Kiadó, Budapest.

Lévy-Bruhl, L. (1910/1985): How Natives Think. Princeton University Press, Princeton.

Lévy-Bruhl, L. (1975): The Notes on Primitive Mentality. Blackwell Publishers, Oxford.

Lévy-Strauss, C: (1962): La penséé sauvage. Plon, Paris.

Lurija, A. R. (1979): Cultural differences in thinking. In: Cole, M. és Cole, S. The Making of Mind. Harvard University Press, Cambridge, MA.

Markova, I. (2000): Amédée or How to Get Rid of It: Social Representations from a Dialogical Perspective. Culture \& Psychology, 2000 Vol. 6 (4), 419-460.

McLuhan, M. (1976): La galassia Guttenberg. Armando, Roma. Moliner, P. (1995): A two-dimensional model of social representations. European Journal of Social Psychology, 25, 27-40.

Moscovici, S. (1961): La psychoanalyse, son image et son public. Presses Universitaires de France, Paris.

Moscovici, S. (1973): Foreword. In: Herzlich, C. (szerk.) Health and IIlness: A social psychological analysis. Academic Press, London.

Moscovici, S. (1981): On social representations. In: Forgas, J. P. (szerk.) Social cognition. Perspectives on everyday understanding. Academic, London, 181-209. 
Moscovici, S. (1988): Notes toward a description of social representations. European Journal of Social Psychology, 18, 211-250.

Moscovici, S. (1998): Social Consciousness and its history. Culture \& Psychology, Vol. 4, No. 3, 411-429.

Moscovici, S. és Hewstone, M. (1983): Social representations and social explanations: from the "naïve” to the „amateur" scientist. In: Hewstone, M. (szerk.) Attribution theory, social and functional extensions. Blackwell, Oxford, 98-125.

Moscovici, S., (1984): The Phenomenon of Social Representation. In: Farr, R. és Moscovici, S. (szerk.) Social Representations. Cambridge Univerity Press, Cambridge, 3-70.

Mugny, G. és Carugati, F. (1989): Social representations of intelligence. Cambridge University Press, Cambridge.

Ong, W. J. (1986): Oralitá e scrittura. Le tecnologie della parola. II Mulino, Bologna.

Philogène, G. (1994): African American as a new social representation. Journal for the Theory of Social Behaviour, 24, 89-109.

Piaget, J. (1926): The child's conception of the world. Granada, London.

Piaget, J. (1972): II giudizio morale nel fanciullo. GiuntiBarbera, Firenze.

Pléh Csaba (1996): Szociális modellek és a megismeréskutatás: Spekulativ áttekintés. Előadás a Magyar Kognitív Tudományi Alapítvány IV. Megismeréstudományi Konferenciáján, 1996. január 31. Gödöllő.

Potter, J. és Litton, J. (1985): Some problems underlying the theory of social representations. British Journal of Social Psychology, 24, 81-90.

Spini, D. és Doise, W. (1998): Organising principles of involvement in human rights and their social anchoring in value priorities. European Journal of Social Psychology, 28, 603-622.

Vigotszkij, L. S. és Lurija, A. R. (1993): Studies in the History of Behaviour. In: Golod, V. és Knox, J. E. (eds.) Ape, Primitive and Child, Hillsdale. NJ, Lawrence Erlbaum Associates.

Wagner, W. és Hayes, N. (2005): Everyday discourse and Common Sense, Palgrave, Hampshire. 
Wagner, W. (1998): Social Representations and beyond: Brute Facts, Symbolic Coping and Domesticated. Culture Psychology, 4, 297-329.

Wagner, W., Duveen, G., Farr, R., Jovchelovitch, S., LorenzoCioldi, F., Marková, I. és Rose, D. (1999): Theory and method of social representations. Asian Journal of Social Psychology, 2, 95-125.

Wagner, W., Kronberger, N. és Seifert, F. (2002): Collective symbolic coping with new technology: knowledge, images and public discourse. British Journal of Social Psychology, 41, 323-343. 



\section{Az oktatási rendszer szociológiája}

Ez a fejezet a nevelésszociológia és az oktatási rendszer viszonyáról szól. Ez a kapcsolat rendszerint kimarad a hagyományos nevelésszociológiákból. A nevelésszociológia ugyanis hagyományosan informális és formális nevelésről (tanulásról, szocializációról) beszél; és „formálison” a nevelés (tanulás, szocializáció) minden szervezett keretét érti. E szervezett keretek közt (is) megy végbe a nevelés (tanulás, szocializáció), amelyet a nevelésszociológia vizsgál. A nevelésszociológia szempontjából nem fontos, hogy a nevelés szervezett keretei hogyan, miképp szerveződtek meg és milyen szervezeti sajátosságokat mutatnak. Ezért a nevelésszociológia számára fontosabb az iskola, mint az oktatási rendszer, amelybe az iskola beleilleszkedik. Ezért szokták a nevelésszociológusok megkerülni az oktatási rendszer problémáit.

$\mathrm{Az}$ alábbiakban pótolni igyekszünk ezt a hiányt. Bevezetőben bemutatjuk, hogyan határozza meg az iskolát mint szervezetet az a nagyrendszer, amelybe beletartozik (oktatási rendszer). Majd áttekintjük az oktatási rendszerek két alaptípusát (európai vagy kontinentális - és angolszász vagy atlanti), összefoglalásként pedig arra mutatunk rá, hogyan változik az iskola keretei közt folyó szocializáció (formális nevelés) aszerint, hogy maga az iskola milyen típusú oktatási rendszerbe tartozik.

Ez a fejezet két korábbi tankönyvünk szövege alapján íródott. A formális nevelés szociológiája megtalálható a Bevezetés a nevelésszociológiába c. tankönyvben, az oktatási rendszerek alaptípusait pedig Az összehasonlító neveléstudomány alapjai c. könyvünkből emeltük át. 


\section{Az oktatási rendszer szociológiája}

A következő részben a nevelésszociológia és az oktatási rendszerek kapcsolatáról lesz szó. Röviden bemutatjuk, mit értünk „nevelésszociológián”, és ennek a szakszociológiának (vagy neveléstudományi határterületnek) mi a kutatási területe. Majd összefüggést keresünk a nevelésszociológia és az oktatási rendszer között. Végül összefoglaljuk az oktatási rendszerek szociológiájának legfontosabb irányait.

\section{A nevelés szociológiája}

A nevelésszociológia a nevelést mint társadalmi tevékenységet fogja föl. A nevelést egyetemes emberi tevékenységnek mutatja be, amely végigkíséri az emberiség fejlődését kezdetektől egészen napjainkig; és az ember fejlődését a bölcsőtől a koporsóig. A nevelésszociológus szerint a nevelés az emberi létet meghatározó tevékenység, amelynek révén az egyén a közösség tagjává válik, miközben kialakul az egyénisége; a társadalom fönnmarad azáltal, hogy újabb és újabb tagokat vesz föl; a nemzedékek átörökítik egymásnak tudásukat, mert enélkül minden generáció újra kezdhetné az emberré válás hosszú útját.

Erre az alapvető emberi tevékenységre - a nevelésre - különféle társadalomtudományok különféle elnevezéseket használnak. A pedagógusnak az a természetes, ha az iskolai (vagy iskolán kívüli pl. családi) nevelésre gondol. A néprajzosnak, kultúrantropológusnak a „szocializáció” jut minderről az eszébe. A szervezetkutatók és közösségfejlesztők (andragógusok, felnőttképzők) a "társadalmi tanulásra” gondolnak. Ezekben az a közös, hogy a „nevelést” tágan használják, spontán folyamatnak fogják föl, és egyéni/közösségi életünk minden mozzanatában fölfedezik.

A nevelésszociológia azokat a társadalmi kereteket (együtteseket, ágenseket) vizsgálja, amelyek között az így fölfogott nevelés végbemegy. Ezek az emberi együttélések legváltozatosabb együttesei lehetnek a családtól a baráti közösségeken át a szervezett tanítástól a munkahelyi csoportokig. Informálisnak szokták - ebben az összefüggésben - nevezni azokat a tár- 
sadalmi együtteseket, amelyek spontán, alulról szerveződnek meg (család, életkori csoportok); formálisnak pedig azokat, amelyek szervezett keretet nyújtanak a legkülönfélébb nevelődésnek/tanulásnak/szocializációnak. (Ilyenek a legkülönfélébb iskolák és munkahelyek, de ilyenek az életünket körülvevő és behálózó egyéb szervezetek is, mint pl. a bolt, az üzem, a kórház, a tűzoltóság vagy a katasztrófavédelem.)

\section{Nevelésszociológia és oktatási rendszer}

A fölsoroltak közül a nevelésszociológiát hagyományosan az iskola érdekli a leginkább. Az iskolával kapcsolatban azt vizsgálja, hogy a nevelés/spontán vagy társadalmi tanulás/szocializáció hogyan megy végbe benne. (Tehát nem a tanítási-tanulási folyamatot vizsgálja, hanem például azt, hogy a pedagógiai folyamatokat hogyan befolyásolják, módosítják, változtatják meg a spontán, nem tervezett szocializációs folyamatok.) Az ezzel kapcsolatos vizsgálatok - amelyek mintegy hetven-nyolcvan évre tekintenek vissza a nevelésszociológia történetében (Margaret Mead) - egyértelműen kimutatták, hogy az iskola nem egymagában hat a benne tanulókra, hanem a tanulók kultúráján keresztül. Ezt a kultúrát a fiatalok magukkal hozzák az iskolán kívüli világból; ezzel a kultúrával kell megütköznie az iskolának, amikor a tanítás-tanulási folyamatot menedzselni próbálja.

Ezért a nevelésszociológus számára az iskola nem zárt világ, hanem nyílt szervezet, amelybe mind a fiatalok, mind pedig tanítóik, tanáraik magukkal hozzák a helyi társadalom világát (kultúráját, azaz intézményeit, viselkedési mintáit, valamint értékeit és szankcióit). A nevelésszociológusok általában azt hangsúlyozzák, hogy az iskola, amelyet megvizsgálnak, az őt körülvevő társadalom része, és csak a helyi társadalom szervezeteként érthető meg.

Kevesebbet hangsúlyozzák, hogy az iskola nem csak a helyi társadalom része, hanem egy hivatali nagyszervezet mégpedig az iskolarendszer része ${ }^{1}$ is. Ezek a térben is különbözőképpen helyezkednek el: kis településeken csak alapiskolák vannak, nagyobb településeken magasabb fokúak is. Elhelyezkedésük visszahat a települések városiasodására Azaz, az iskolarendszernek térszervező hatása van. 
$\mathrm{Az}$ iskolarendszert és annak irányítását együtt oktatási rendszernek szokták nevezni. Az oktatási rendszer tehát magában foglalja az iskolák egymás utánját, valamint az azokat fenntartó, irányító, finanszírozó hatóságokat. Az, hogy milyen oktatási rendszerbe illeszkedik a környék iskolája, meghatározza azt is, hogyan illeszkedik a helyi társadalomba. Úgy illeszkedik bele - nyíltabb vagy zártabb szervezetként - ahogy az oktatási rendszer hagyományosan azt meghatározza. Így befolyásolja - távolról, de nagyon is érezhetően - az oktatási rendszer maga is az iskolában folyó spontán szocializációs folyamatokat.

\section{Az oktatási rendszer szociológiája}

Az „oktatási rendszer" - ahogyan ezt itt röviden leírtuk - a 18-19. század fejleménye (elsősorban Európában), és a társadalomkutatók figyelmét a 20. század első felében keltette föl.

- A közgazdászok azt vizsgálták, hogyan járul hozzá „az oktatás" (vagyis hogy részt veszünk-e az oktatási rendszerben) a gazdasági fejlődéshez, illetve az egyén gazdasági teljesítményéhez és boldogulásához. Az ezzel kapcsolatos nézeteket az oktatás-gazdaságtan kézikönyvei foglalják össze.

- A társadalmi struktúra és mobilitás kutatói szerint a társadalmi „szerkezet” kialakulásához, a társadalmi szerkezetben (struktúrában) való egyéni elhelyezkedéshez, az abban történő helyváltoztatáshoz (mobilitás) a legfontosabb az egyének és csoportok oktatási eredményessége. A társadalmi struktúra és az oktatási rendszer kölcsönhatásainak kutatása az oktatásszociológia legfontosabb terepe.

- Az oktatási rendszer mint történeti-társadalmi fejlemény mint „társadalmi szervezet" - az oktatáskutatás közismert tárgya. A 20. század harmadik harmadában különösen az oktatási rendszer expanziójának (kiterjedésének) kutatása vált fontossá. (Margaret Archer).

- Az oktatási rendszer „térszervező hatását” a társadalomföldrajz (szociálökológia, oktatásökológia) vizsgálja. Kimutatták a településhierarchia és az oktatás szerkezete közötti 
összefüggéseket; valamint az oktatási rendszer hatását a demográfiai folyamatokra. (Az oktatásföldrajz máig érvényes kézikönyvét Peter Meusburger írta.)

Mi a következőkben az oktatási rendszerek két alaptípusát (európai vagy kontinentális, illetve angolszász vagy atlanti) mutatjuk be. Azt keressük, hogy az iskolai spontán nevelődés/társadalmi tanulás/szocializáció mennyire változik az egyik vagy a másik alaptípusban.

\section{A kontinentális rendszer}

\section{A kontinentális rendszer kialakulása}

A felvilágosodás hatása. A felvilágosodás hatására az abszolút uralkodók politikája fokozatosan telítődött az alattvalók „fölvilágosításának” szándékával és különböző „népjobbító”, „népboldogító” politikákkal. A 18. század második felében a francia felvilágosodás legkiemelkedőbb képviselői nemcsak a Nagy Enciklopédiát írták - bennük a felvilágosodás jellegzetes állásfoglalásait és ítéleteit is -, hanem különböző nevelésügyi reformtervezeteket is. Ez utóbbiakat sokszor abszolút uralkodók (Mária Terézia, Nagy Katalin), illetve abszolút hatalomgyakorlási helyzetbe került hatalmi csoportok (pl. a lengyel szejm) fölkérésére.

A francia forradalom hatása. A francia forradalom széttörte az abszolutizmus nyújtotta (oktatás)politikai kereteket, és új teret teremtett a társadalomnak nemcsak a megjobbítására, hanem a megváltoztatására is. Hatása mintegy száz évre egészen az első világháborút követő szocialista forradalmakig - befolyásolta az európai értelmiség társadalompolitikai ismereteit, attitűdjeit és értékvilágát. A francia forradalom (tulajdonképpen minden valamire való forradalom) teremtett olyan tabula rasa-t (tiszta lapot), amelyen új alapra lehetett helyezni az egész közösségre vonatkozó oktatást is.

A napóleoni korszak hatása. A kontinentális rendszer előzményei Napóleonig vezethetők vissza. A modern (polgári) állam közoktatását - akárcsak pl. a kötelező katonai szolgálatot 
stb. - Napóleon idején törvényesítették. Az oktatás törvényesített rendszerét, amely része volt a francia politikai állam kialakításának - a napóleoni háborúk exportálták. Európának azokon a részein, amelyek Napóleon befolyása alatt szerveződtek újjá (rendszerint általa kinevezett vagy megerősített uralkodókkal), átvették és polgári átalakulásuk alapjává tették a napóleoni kodifikált jogot, és kialakították a francia mintájú oktatási rendszert.

A napóleoni „fölszabadítás” lendülete azonban a német államok és tartományok határán megtört. Európa középső és keleti felében a napóleoni reformok már nem (nem csupán) fegyverrel jöttek el, hanem a helyi reformerőkre támaszkodva is. Közép-, illetve Kelet-Európában ezért a francia oktatási rendszer hatásai közvetve, áttételesen érvényesültek. A felvilágosodás, a forradalom és a napóleoni kihívás eredményeképpen ezekben az országokban a francia oktatási rendszer reakciójaként születtek meg az oktatási rendszerek.

\section{A rendszer meghatározója: a klasszikus középiskola}

Jellemzők. A klasszikus középiskolát - bármilyen néven szerveződött is meg és bármely nemzeti oktatási rendszer részét képezte - alapvetően meghatározták a következők.

- Nem a diákokat tanították benne, hanem a tantárgyakat. A tantárgyak a tudomány mindenkori állása szerinti osztályozást követték; a tantárgyak a kor tudományainak kicsinyített másai voltak.

- Az intézményszervezés alapja a tantárgyak felosztása volt. Az egész intézmény annak megfelelően szerveződött, hogy hol, mikor kellett az egyes tárgyakat a fiataloknak megtanítani. A klasszikus középiskola tantárgyrendszere képezte az alapját a középszintű oktatás más intézménytípusainak csakúgy, mint a tanárképzésnek - sőt az iskolaépítésnek is.

- Záróvizsga. A klasszikus középiskolai tanulmányokat ünnepélyes és tudományos záróvizsga zárta le. Ez a vizsga volt a legszigorúbb és a legjelentősebb az egész oktatási rendszerben (nem számítva most ide a felsőoktatásban szerezhető diplomákat és fokozatokat). Ez a vizsga a felsőoktatás 
„bizottsági vizsgáit” utánozta. Bizottság előtt kellett letenni, a bizottságot a fenntartók jelölték ki. Maga a vizsga is inkább egyetemire, semmint mai értelemben vett iskolai vizsgára hasonlított. Tantárgyi alapú volt, általában írásos és szóbeli részekből állt. Az ünnepélyes és szigorú vizsga eredményeképpen egyfajta középiskolai diplomát (érettségi bizonyítvány stb.) kapott a fiatal. Ez a vizsga egyetemi továbbtanulásra, illetve a közalkalmazotti létre jogosított föl.

Célja. A klasszikus középiskola célja, hogy az államigazgatásnak közhivatalnoki réteget képezzen, ezen keresztül pedig mintegy kifejezze a nemzetállamot - sőt, hozzájáruljon annak kialakulásához.

- Professzionális államigazgatás. A klasszikus középiskola alakította ki az „állam támaszait”, vagyis az adminisztrátorokat (francia) vagy bürokratákat (német). A közigazgatás professzionalizálódásával és megszervezésével egyre több hivatásos közhivatalnokra volt szükség. A klasszikus középiskola tulajdonképpen ennek a hivatalnokrétegnek a kialakítását és professzionalizálódását szolgálta.

- Nemzetállami identitás. A föntiek következtében a klasszikus középiskola a 19. század második felére az Európa-szerte kialakuló nemzetállamok identitásának kifejezőjévé vált. Mert:

- benne készültek föl államigazgatási szerepükre az állam „jövendő támaszai”, a bürokraták,

- hivatalossá tette, múvelte és terjesztette az addig jobbára csak a törvényhozásban használatos nemzeti (hivatalos) nyelvet,

- kialakította, terjesztette és egységesítette a nemzetállami történelmet (a kor politikatudományát),

- hozzájárult az igazgatás, a közlekedés és a hírközlés központosításához,

- megalapozta a nemzetállami szabványosításokat stb.

Funkciói. A klasszikus középiskola - a felsoroltak mellett - további társadalmi hatásokkal (funkciókkal) is járt. A legfontosabbak: 
- A közalkalmazotti középosztály megteremtése. A klasszikus középiskola megszervezése hozzájárult ahhoz, hogy a kontinentális Európában a társadalmak „középosztályai” lényegében köztisztviselőkből és közalkalmazottakból formálódjanak ki. (Az angolszász világban ez másként alakult; a köztisztviselői réteg sokkal szúkebb maradt, a társadalmak középosztályai pedig másokból, főként a polgárságból tevődtek ki.) A közalkalmazotti lét mint életforma és mint gazdasági biztonság fölértékelődött; a munkásmozgalmak egyik fő célkitűzése lett, és a 20. századi Európában kialakult pártállamokban, ahol a gazdaságot államosították, általános létformává vált.

- A társadalmi mobilitás csatornája. A klasszikus középiskola egyúttal egy foglalkozás intézményévé is vált. Ebben a minőségében a vertikális (többlépcsős) társadalmi mobilitás egyik legfontosabb csatornája is lett azokban a társadalmakban, amelyekben a közalkalmazotti lét vált a középosztály létformájává.

- Az oktatási rendszer meghatározója. A kontinentális rendszerben ez a klasszikus középiskola fejezte ki az oktatási rendszer „szellemét”, vagyis ehhez az intézménytípushoz igazodott a többi iskolatípus is. Ennek az a magyarázata, hogy mind a szülők, mint a tanárok, mind a fenntartók a klasszikus középiskolát tekintették a (köz)oktatás csúcsának, ennek következtében ennek a jellemzőihez igyekeztek igazodni.

\section{A rendszer szerkezete}

A klasszikus középiskola határozta meg az egész rendszer „szerkezetét”. Ez azt jelenti, hogy minden más intézménytípust a klasszikus középiskolához viszonyítottak, ehhez kapcsoltak hozzá. Azt vizsgálták, hogy az alapfokú oktatás, a felsőfokú oktatás vagy más középiskola-típusok hogyan vezetnek a klaszszikus középiskolához vagy hogyan viszonyulnak hozzá.

Közös vonások. Az európai rendszerek szerkezetét néhány fontos, közös vonás jellemzi. Ezek a következők.

- Hármas tagoltság. Az európai iskolarendszerek három szintből állnak: első szint (vagy alapfokú oktatás), második szint (középfokú oktatás) és harmadik szint (felsőfokú oktatás). 
- Szelektivitás. E „szintek” közt az átmenet eredetileg nem folyamatos volt, hanem szelektív. Az alacsonyabb szintről a magasabbra különféle vizsgákkal választották ki azokat, akik tovább tanulhattak. Ezek a válogató vizsgák arra szolgáltak, hogy egy-egy tanulói korosztály (az egy évben születettek) közül csak a kiválasztottak („legjobbak”, „rátermettek”, „tehetségesek” stb.) jussanak tovább.

- „Többcsatornás” haladás. A legtöbb nemzeti rendszerben a továbbtanulás számára több intézménytípus alakult ki egymással mintegy „párhuzamosan”. Ez főként a második szinten (középfokon) vált jellemzővé. Azért alakultak ki különböző továbbtanulási utak, hogy azokat is bent tartsák az iskolarendszerben, akiket nem vettek föl a klasszikus középiskolába.

- A választás koréve. Az európai rendszerek szerkezetét mindenhol jellemzi, hogy a tanulóknak hány éves korukban kell választaniuk továbbtanulást, illetve jövendő pályát. Ezek az első választások eredetileg 10-12 éves korban következtek be aszerint, hogy egy-egy országban mikor kezdtek a gyerekek iskolába járni.

Eltérő típusok. A fenti szerkezeti vonások minden európai oktatási rendszert jellemeznek. A rendszerek változásakor, átalakításakor éppen ezek a szerkezeti jellemzők változnak meg látványosan. E szerkezeti jellemzők szerint az európai oktatási rendszereknek két típusát különböztetik meg. Ezek: a francia és a német típus.

- A francia típus. A francia típus jellegzetessége, hogy intézménytípusai három évfolyamosak (vagy a három többszörösei). A szakképzés és az általános képzés is az oktatási rendszeren belül szerveződik. A bakkalaureátus nagy jelentőségü, szelektív hatású vizsga, amely a tanuló sorsát is meghatározhatja. Egyes intézménytípusok ma (2015) már nem csak három évfolyamosak. Ennek az az oka, hogy előkészítő vagy pótló évfolyamokat csatoltak hozzá. Ezt rendszerint az elnevezések is sugallják.

- A német típus. A német típusú oktatási rendszer szerkezete eredetileg négy évfolyamokból állt (a négyes osztást még 
mindig föl lehet ismerni rajta). A német típusban a választás igen korai - ezt a középfokú oktatás különféle egységesítésével próbálták később enyhíteni. A szakképzés alapvetően az oktatási rendszeren kívül zajlik. A párhuzamos (szak)képzés a felsőoktatásban is követhető, egészen máig (2015). (Megjegyezzük itt, hogy nem Németországnak van rendszere, hanem az egyes német tartományoknak; ez az összefoglalás megkísérli ezek lényeges vonásait összesűríteni.)

A második világháborút követően a kontinentális rendszer szerkezetét sok európai országban átalakították. Egybeszervezték az alapfokú oktatást a középfokú oktatás alsó tagozatával (általános vagy alapiskola), hogy megszüntessék vagy későbbre tolják az alapfok és a középfok közti átmenet korévét. Az 1970-es évek oktatási reformjaiban a klasszikus középiskolából egységes, szakképzési programokat is tartalmazó (politechnikai) középiskolákat szerveztek. Az Európai Unió 2004-es bővítésétől kezdve a Brüsszeli Bizottság (az Unió kormánya) egyre határozottabban törekszik a tagállamok oktatási rendszereinek egyfajta „egységesítésére”. Bár ezeket a reformokat úgy népszerűsítik, mint a kontinentális rendszer megszüntetését, valójában csupán módosították a kontinentális rendszer szerkezetét. A rendszer szerkezete alapjaiban máig (2015) nem változott meg, csupán módosult.

\section{Tartalom}

A tanár. A kontinentális rendszer háromosztatú és „többcsatornás". Ebből következnek az alábbiak.

- A tanárok (pedagógusok) képzése külön-külön intézményekben történt más-más oktatási szinteknek, illetve a „többcsatornás” középfokú oktatásnak megfelelően. Az alapfokra (és azt megelőzően) eredetileg középiskolákban képeztek tanítókat és óvónőket. E középfokú oktatási intézmények a 20. század közepén lettek felsőfokúakká. Így a felsőoktatás részei, de rendszerint nem egyetemiek még a 20. század végén sem. A klasszikus középiskolák professzorait egyetemen képezték (nem mindig követelve meg tő- 
lük a teljes egyetemi tanulmányokat). A leendő egyetemi tanároknak viszont tudományos fokozattal (doktorátus), magántanári vizsgával stb. kellett rendelkezniük.

- Az oktatási rendszer más-más szintjén tanító pedagógusok társadalmi pozíciója is különböző volt; más és más társadalmi rétegbe tartoztak, rendszerint végzettségük szerint. (A klasszikus középiskola tanárai - a rendszer „támaszai” és az oktatási rendszer „modelljei” - hagyományosan a közalkalmazotti középosztály tagjai voltak.)

- A tanárok érdekképviselete kamarai, nem pedig szakszervezeti jellegú. Ez is azt fejezte ki, hogy a tanárok (és a pedagógusok) nem a munkásosztály tagjai, hanem a középrétegeké. Esetükben a szakmai-tudományos szervezkedés volt az elfogadható, akárcsak a köztisztviselők és közalkalmazottak körében.

A tanterv. A kontinentális rendszerben a tantervnek is sajátos jelentése alakult ki. Ez magyarázza a sokszor elkeseredett szakmai-tudományos vitákat akörül, hogy milyennek kell lennie a „jó tantervnek”. A kontinentális rendszer tantervét általánosságban a következők jellemezték.

- Központi tanterv. A tantervet nem a 20. század diktatórikus államaiban központosították (vö. pl. „sztálini tanterv”). A központi tanterv a kontinentális rendszer „logikájához" tartozik. A központban körvonalazott tananyag megtanítása volt a kontinentális rendszer legfontosabb feladata. Ezért kellett a tantervnek alapvetően központinak lennie.

- Egységes tanterv. Ez a helyzet a központi tantervből következik. Egy központi tantervnek csak akkor van értelme, ha egységes, legalábbis iskolatípusonként. Az eltérő variációkat is központilag és egységesen tervezik meg és ajánlják.

- A tanterv mint sillabusz. A központi és egységes tanterv a tanárok számára készül, és a tanítási anyag felsorolását tartalmazza (a „sillabusz” szó listát, felsorolást, vázlatot jelent). Tehát nem pszichikus képességeket vagy elérendő készségeket stb. tartalmaz, hanem a tanítási anyag tartalmát, kötelező témáit. A tanterv nem a diákok munkaterve, hanem a tanároké. 
A tankönyv. Az egységes központi tanterv meghatározza a tankönyvek jellegét, természetét, sőt kiadását és forgalmazását is. A kontinentális rendszer „logikája” szerint a tankönyvet az alábbiak jellemzik.

- A tankönyv tudományos kiadvány, a tudományos könyvek között a helye. (Egyetemi, esetleg gimnáziumi tankönyvként - különösen ha az adott nyelvet viszonylag kevesen beszélik, tudományos múveket használnak. És fordítva: a tudományos könyvkiadás és a tankönyvkiadás nagymértékben átfedik egymást.)

- A tankönyv a tantervben fölsorolt tananyag foglalata. Ezért van az, hogy a tanár a tankönyvet tanítja; a tankönyv egyben a tanár „,kézikönyve” is (tehát nem a diákot munkáltató könyv, amelyet fejleszteni, kiegészíteni lehet).

- A tankönyv hivatalos jellegú kiadvány. Ez azt jelenti, hogy hivatalosan hagyják jóvá, engedélyezik; az engedélyezési eljárás rendszerint kormányzati szinten (oktatási minisztériumok) történik. Csak az engedélyezett tankönyv minősül tankönyvnek, miután hivatalosan bizonyították, hogy tartalma egybevág a tantervvel.

- Mint hivatalos jellegú kiadványt, a tankönyvet az állam adja ki; rendszerint központi kiadója segítségével. Nem minden nemzeti rendszerben múködik persze központi állami tankönyvkiadó, különösen az 1980-as évek óta (Európa keleti felében az 1989/90-es fordulat óta). A tankönyvek engedélyezési eljárása annál fontosabb, mennél nagyobb a privát tankönyvkiadás szerepe a nemzeti oktatási rendszerekben.

A vizsga. A kontinentális rendszer szerkezete többszintes és szelektív. Ennek következtében a kontinentális rendszerben a vizsgák egyik funkciója, hogy kiválasszanak (szelektáljanak), a másik célja pedig, hogy lezárjanak, befejezzenek.

- A vizsgák szimbolikus jellege. A kontinentális rendszerben a vizsgának szimbolikus jelentősége van. Nemcsak szűkebben szakmai jelentéseket tulajdonítanak neki (a tananyag ismerete, a készségek gyakorlása, a teljesítmények összemérése stb.), hanem tágabban oktatáspolitikai, sőt társa- 
dalmi jelentéseket is. A vizsgák oktatáspolitikai jelentése a kiválasztás és a továbbjuttatás a rendszeren belül (vagy kizárás a rendszerből). A vizsgák társadalmi jelentése: felvétel abba a társadalmi csoportba, amelybe az iskola elvégzése révén kerülhetünk.

- A vizsgák társadalmi funkciója. Ennek következtében a kontinentális rendszer legfontosabb vizsgái egyben a társadalmi mozgásokat, folyamatokat, sőt a társadalmi átalakulásokat is meghatározhatják. Minthogy a vizsgák révén kerülhet az egyén lejjebb vagy följebb a képzeletbeli társadalmi ranglétrán, a vizsgáknak társadalmi szelekciós szerepe is van. Ha változtatjuk őket, egyben fontos társadalmi szelekciós mechnizmuson is változtatunk.

\section{Irányítás}

Iskolaalapítás. A kontinentális rendszer „logikája” szerint az iskola az államé (nem pedig a helyi közösségé, az egymással szövetkező szülőké vagy különböző piaci vállalkozásoké). Ez még akkor is igaz, ha minden európai rendszerben vannak önkormányzati, alapítványi és más nem kormányzati iskolák (a nem kormányzati szervezetek oktatáspolitikai részvételéről Id. a vonatkozó fejezetet). Mindez nem változtat azon a történeti gyökerű fejleményen, hogy Európában az iskolát az uralkodó vagy elődje, az egyház - alapította.

Finanszírozás. A kontinentális rendszer intézményeit - az elmondottak következtében - az államkincstár tartja fönn, finanszírozza. A kontinentális rendszer „logikájából” adódóan az iskolák állami intézmények, következésképpen a költségvetés tartja el óket.

Igazgatás. Ugyancsak a kontinentális rendszerek „logikája", hogy az iskolák irányítása az államigazgatás egyik részét képezi. Súlya, fontossága és helye az államigazgatáson belül természetesen eltérő lehet. Ezek a különbözőségek azonban nem érintik a rendszer „logikáját”, azt, hogy az oktatásigazgatás nem önálló, hanem mintegy leképezi, tükrözi az adott állam igazgatási rendszerét. Az oktatásigazgatás minden európai államban a központi szakigazgatás egyik fontos szektora. 


\section{$A z$ atlanti rendszer}

\section{Gyökerek}

Európa -felvilágosodás nélkül. Az atlanti rendszer a „felvilágosodás nélküli" (vagy felvilágosodás előtti) európai oktatás vonásait mutatja. A felvilágosodás (a felvilágosult abszolutizmus) előtti oktatási rendszer a nyugati egyház oktatási rendszerén alapult. A rendszer jellemzői a következők voltak.

- A püspökök székhelyén felsőfokú oktatási intézmények működtek. Ezek az intézmények az egyház „káderutánpótlását" voltak hivatva szolgálni.

- A püspöki székhelyeken müködő intézményekhez csillagszerúen kapcsolódtak az alsófokú iskolák. Ezeknek az volt a szerepük, hogy előkészítsenek a felsőfokú tanulmányokra. Egy-egy felsőfokú intézmény és partikulái együttesen képeztek egységet.

- Ezek az „oktatási rendszerek” nem voltak egymásnak alá-fölé rendelve, hanem egymással csupán hálózatot alkottak. A fölérendelt intézmény az egyetem volt (Párizs, Bologna stb.).

Reformáció és népoktatás. Az egyházi oktatási rendszer elsősorban a papi-szerzetesi utánpótlást biztosította. A hívek „oktatása" a templomban történt (többek közt az istentiszteleti alkalmakon). Az európai reformáció a 16. században gyökeresen változtatott ezen.

- Az istentisztelet középpontjába - az egyházi felsőoktatás mintájára - a Biblia olvasását és magyarázatát állította (igehirdetés; a lelkészek az akadémiai talárjukat vagy palástjukat viselték),

- bibliamagyarázatuk megértéséhez szükséges volt, hogy mindenki olvasni tudja a Bibliát,

- a vallási gyülekezetek újjászervezéséhez pedig az együttes olvasás, imádkozás és éneklés vált szükségessé (új, a népénekek dallamain alapuló egyházi énekekkel),

- mindezt lehetővé tette a kor nagy találmánya, a könyvnyomtatás. 
Ezért a reformáció mintegy „aláépítette”, eléje szervezte az egyháztól örökölt oktatási rendszernek a népoktatást. A protestáns népoktatás vált a felvilágosodás előtti Európa oktatási rendszerének az alapjává, amelyre az egyháztól örökölt partikulák és akadémiák „épültek rá”. Ez az az oktatási rendszer, amelyet az atlanti térségben (nyomokban bár) ma is láthatunk.

\section{A közösség iskolája}

Kialakulása. A „közösség iskolája” - vagyis a helyi intézmény, amelyet a közösség tagjai alapítanak, építenek, tartanak fönn és irányítanak - csakugyan így keletkezett, legalábbis Új-Angliában, ahová a puritán bevándorlók érkeztek a Mayflower hajón (1647). Kereskedőszokás szerint már a hajón megkötették a maguk szerződését, amelyet közös imával pecsételtek meg, és amely aztán az új-angliai puritánok alapszerződésévé is vált egészen a függetlenségi háborúig. Az első puritán telepesek államaiban (pl. Massachusetts) a közösségek iskolái mind a mai napig önállók és autonómak. Akárcsak a puritán vallási gyülekezetek, azt a függetlenséget jelképezik és testesítik meg, amelyet a puritán bevándorlók biztosítottak maguknak, amikor az angol király és az anglikán egyház elől az Atlantióceánra és az amerikai gyarmatokra menekültek. $A$ „,közösség iskolája” ezért az atlanti rendszer egyik szimbóluma.

Funkciói. A közösség iskoláját azért alapították, hogy a gyerekeket és fiatalokat a közösség tagjává tegyék vele, általa. Ezért

- a tanítás anyagát meghatározta vagy alaposan átszínezte a közösség kultúrája (ismeretei, mintái, értékei és normái),

- e telepes közösségek fizikai munkából, a természet meghódításából éltek; iskoláik is gyakorlatorientáltak voltak,

- az újonnan érkezetteket, letelepedni szándékozókat vagy a helyi lakosokat (indiánok) csak akkor voltak hajlandók befogadni, ha elfogadták a közösség kultúráját; a közösség iskolája volt a közösségi „olvasztó tégely”.

Szerkezete. Hiába keressük az amerikai oktatási rendszer szerkezetét - vagy akár Nagy-Britanniáét -, ilyent nem találunk. Az 
atlanti rendszer egyik jellegzetessége, hogy a rendszer „szerkezetét" - ahogyan azt európai szokás szerint várnánk - nem tartják számon. Ez adódik abból a hagyományból, hogy az atlanti rendszer „alulról” épül föl és válik rendszerré (egy vagy több rendszerré, egyetlen országon belül).

A kontinentális rendszer szerkezete lényegében az igazgatás rendszerét türközi. Az iskolatípusok úgy rendelődnek egymás alá és fölé, ahogyan a hivatali szervezetben szokás (az alsófokú oktatás után a középfokú következik, azt a felsőfokú oktatás követi). A kontinentális rendszer szerkezetét az oktatásigazgatás, azt pedig a közigazgatás (államigazgatás) tartja össze. Az atlanti rendszernek nincs ilyen összetartó ereje, minthogy alulról, az egykori közösségek intézményei alapján alakult ki, nem pedig felülről, az egykori uralkodó udvarából. Mi tartja akkor mégis össze az egyes iskolákat? Mitől válik rendszerré a rendszer? A válasz a tanulók haladási útjában rejlik, amelyet az iskolai „fokozatok” (minősítések, szintek, rangok) szegélyeznek. Egy-egy intézménybe csak akkor lehet beiratkozni, ha valamilyen fokozatot (vagy legalábbis egy előírt teszteredményt) már megszerzett a pályázó. Az atlanti rendszert az egymás után következő fokozatok tartják össze és szervezik rendszerré.

Bár az atlanti rendszernek nincs „szerkezete” - amit grafikusan szokás ábrázolni minden európai nemzeti oktatási rendszerben -, az egymástól eredetileg eltérő helyi-területi rendszerek itt is fokozatosan szabványosodtak. A fokozatos szabványosodásnak ez a folyamata az atlanti rendszert is egy többé-kevésbé egységesedő rendszer irányába fejleszti. A párhuzamosan kialakult rendszerek tehát fejlődéseik eredményeképp lassan szintén egységesednek. Az egységesülés e lassú folyamata azonban nem jelenik meg az oktatáspolitika és az oktatási jog szintjén. Az atlanti rendszer jelszava máig egyértelmúen az, hogy az oktatás mindig a szövetségre lépők saját ügye, amelyben elvileg nincs helye a központi beavatkozásnak.

\section{Ki mit tanít?}

Mit tanítanak? A tananyag kiválasztását és a tanterv megtervezését az atlanti rendszerben a következők jellemzik. 
- A tananyag helyi kérdés. A közösség iskolájában a tananyag kiválasztásában is a közösség tagjai - rendszerint képviselőik útján - döntenek. Eltérően a kontinentális rendszertől - ahol a tanítás anyaga végső soron tudományos kérdés -, az atlanti iskola tananyaga politikai ügy: a közösség jogkörébe tartozó döntés.

- Szükségletek és kompetenciák. A tanítás anyaga jelentős részben arra szolgál, hogy a közösségbe vezessen be. Ezért az atlanti rendszerben a kompetenciákra (készségekre, képességekre) sokkal nagyobb hangsúly esett - kezdettől fogva -, mint a kontinentális rendszerekben. Az iskola a gyakorlati élet laboratóriuma, ezért tanításának legfontosabb mozzanata az életre történő felkészítés.

- Curriculum. A kontinentális rendszer tantervi sillabuszaival szemben a közösségi iskola tananyagát curriculum típusú tantervek jellemzik (curriculum: versenyfutás, pályafutás). A curriculum típusú tanterv nem a pedagógus számára tartalmaz előírásokat, hanem a tanuló számára mutatja meg a tanulni valót (az iskolai „pályafutását”). Arra szolgál, hogy a tanuló teljesíthesse iskolai pályafutását, amiben a pedagógus támogatja őt. A pedagógus értékeli a tanulót, a tanuló pedig elnyerheti a továbblépéshez szükséges fokozatát.

Tankönyv. A tanítás anyagának másfajta meghatározása befolyásolja és átalakítja a tankönyveket is.

- A tankönyv mint munkaeszköz. A kontinentális tankönyv egyfajta szakkönyv, tudományos teljesítmény (népszerű tudományos munka). Ezek a tankönyvek a pedagógusnak íródtak. Az a tankönyv, amely a fiatalt abban segíti, hogy végigfussa az iskolai pályáját, elsősorban a fiataloknak íródik. Természetesen tartalmaz ismereteket is - de legalább ilyen fontos a munkáltató jellege. Ennek következtében a tankönyvek munkaeszközzé, munkáltató anyaggá, segédanyaggá alakulnak át. Ezt az átalakulást jelentősen befolyásolja az IKT (információs és kommunikációs technológia) megjelenése (virtuális osztálytermek stb.).

- A tankönyv mint áru. A kontinentális tankönyvet hagyományosan az állam adja ki, engedélyezi, terjeszti, szponzorálja 
stb. Ezzel szemben az atlanti rendszerben a tankönyv elsősorban áru. Sikerét a kelendősége, a sokszori kiadás, a gyors átfutás stb. határozza meg.

Ki tanít? Az elmondottak átformálták a tanítók szerepét és magatartását is az atlanti rendszerben.

- A helyi közösség alkalmazottja. Szemben a kontinentális rendszerből ismert „professzor” típusú pedagógussal, a tanító az atlanti rendszerben a helyi (területi) közösség alkalmazottja. Függelmi viszonyai hasonlítanak a közösség más alkalmazottjának viszonyaihoz (mint amilyen a helyi rendőr, a köztisztasági alkalmazott és így tovább).

- Oktatásügyi szakmunkás. Az atlanti rendszerben a fiatal úgy válik pedagógussá, hogy felsőoktatási pályafutása során alapképzettséget (bakkalaureusi fokozat, B.A, B.Sc) szerez valamilyen tudományból, aztán pedig, ha vállalkozik rá, pedagógussá képezik ki (bizonyítványt, esetleg egyetemi fokozatot kap). E diploma utáni kiképzéseknek külön színhelyük van (school of education). Ezt a képzést konzekutívnak (egymást követőnek) nevezik, mivel a szakmai-tudományos képzés a módszertani-technikaitól elválasztva történik. A konzekutív pedagógusképzést gyakran kiképzésnek (teacher training) is hívják, hangsúlyozva ennek a képzésnek a szigorú gyakorlati orientáltságát.

- Professzionalizálódás. Az atlanti rendszerben dolgozó pedagógusok egyik fő törekvése, hogy az „oktatásügyi szakmunkás" (vagy szakalkalmazott) státusából átléphessen a professzionalizáltság státusába. (Professziónak nevezik az atlanti felsőoktatásban az értelmiségi hivatásokat, mint pl. jogász, orvos, mérnök, közgazdász stb.) A pedagógusok egyik fontos törekvése, hogy az ő foglalkozásuk is értelmiségi hivatássá válhasson.

- Érdekvédelem. Mint az oktatásügy szakmunkásai (szakalkalmazottjai), a pedagógusok az atlanti rendszerben ugyanúgy védik az érdekeiket, mint más szakmunkások (szakalkalmazottak). Érdekvédelmi szervezetük a pedagógus-szakszervezet (mint valamennyi szakszervezetnek, a pedagógusok szervezeteinek is különböző irányzatai van- 
nak, a legnagyobb angol és amerikai szakszervezeti tömörülésekhez igazodva).

\section{Kié az iskola?}

Iskolaszék. Az atlanti rendszerben az intézményeket nem a kormányzat irányítja, hanem választott oktatáspolitikai testületek, az iskolaszékek. Ezek helyi vagy regionális testületek, amelyeket a helyi (regionális) képviselő testületek mintájára, azokkal együtt választanak meg a törvényhatósági választások során. Jogkörükbe néhány iskola vagy egy-egy egész területi iskolai hálózat (területi iskolarendszer) tartozhat. Az iskolaszékek az iskola legfőbb irányítói.

Ellenőrzés. Az iskolákban folyó tartalmi munkát Angliában „Őfelsége tanfelügyelője” és annak a hivatala ellenőrzi. Őfelsége tanfelügyelője a kormányzattól független hivatalnok, akit az uralkodó közvetlenül nevez ki. Kis létszámú, magasan kvalifikált és nagy hatalmú szervezete fogja össze a „közösségi iskolákban” folyó tartalmi munkát. Vizsgálatai alapján „oktatáspolitikai irányelveket” javasol az uralkodónak, illetve a kormányzatnak.

- Új menedzserizmus. Az 1980-as évektől kezdve az oktatás irányításában is jelentkezett az „új menedzserizmus”. Az oktatásirányító szervezetek munkájában is megjelentek a „teljesítménymutatók” és az azok alapján történő vezetés. A vállalatirányításból átvett elnevezések és eljárások (minőségbiztosítás, minőségmenedzsment stb.) bekerültek az oktatáspolitikába és a neveléstudományba is.

- Tesztközpontok. Amerikában természetesen nincs „őfelsége felügyelője” (az amerikai angol gyarmatosok már a Függetlenségi Nyilatkozat előtt igyekeztek kibújni az angol udvar központi szerveinek odatelepítése alól). Az iskolai kerületeket (school district) szuperintendensek irányítják. Az említett teljesítménymutatókat szövetségi adatgyűjésekkel helyettesítik, illetve következtetik ki. Ezért központi fontosságúak az egy-egy egyetemre telepített szövetségi teszthivatalok ( $\mathrm{pl}$. a tanulók teljesítményméréséhez, amely a felvételek egyik feltétele). 
- Bíróságok. A hivatali oktatásirányítás (bürokratikus koordináció) hiányában fölértékelődik a jogi ellenőrzés. Ezt a különböző szintű bíróságok végzik azokkal az ítéletekkel, amelyeket oktatásügyi kérdésekben hoznak. A választott oktatáspolitikai testületek határozatai ugyanis bíróság előtt megtámadhatók és a bíróságon született ítéletek hivatkozásul szolgálnak más hasonló ügyekben is.

- Elszámoltathatóság. A helyi és területi oktatásirányítási testületek időről időre beszámoltatják az irányításuk alá tartozó intézményeket. Ezek az átvilágítások és elszámoltatások jelentik a „közösségi kontrollt” az iskolák fölött.

- Finanszírozás. Az irányítás másik fontos eszköze - bürokratikus koordináció híján - az oktatás finanszírozása. Az oktatás finanszírozása áll számos érdekküzdelem központjában a „közösségi iskola” körül. Az oktatás finanszírozása a helyi adókból származik, azok elkülönült része. A szövetségi állam az oktatásügyi költségvetéshez programok finanszírozásával járul hozzá; ezzel befolyásolja az oktatáspolitika szereplőinak viselkedését, feladatvállalásait. A valódi költségek a helyi oktatásügyi hatóság és az állam között oszlanak meg úgy, hogy a pedagógusok fizetését az állam biztosítja.

Iskolakörzetek. A finanszírozás intézményekre, illetve tanulókra lebontható. Ennek a révén úgy lehet az intézményeket (iskolai kerületeiket) irányítani, hogy valamilyen arányban osztják szét az összegeket köztük. Ezért az iskolakörzetbe tartozás rendkívül fontos irányítási és finanszírozási kérdéssé vált. Csak abba az iskolába lehet járni, amelynek körzetében a tanuló és szülei laknak, mert az intézményeket ennek alapján fogja a hatóság finanszírozni.

\section{Iskolai szocializáció és oktatási rendszer}

Az iskolában folyó spontán tanulásokat (szocializáció, nevelődés) nem csak a helyi társadalom határozza meg, amelyben a szervezet múködik. Meghatározza az az irányítási rendszer is, amelynek részeként magát az iskolát fönntartják és irányítják. 
- A kontinentális rendszerben az irányítás általában központosítottabb és hivatalosabb (bürokratikusabb). Ebben a rendszerben az iskola egy hivatali rendszer részévé válik. $A$ benne folyó tevékenységeket - a szocializációs és spontán tanulási folyamatokat is - befolyásolja a szervezet növekvő zártsága. Ezért az iskolai szocializáció rejtettebbé, láthatatlanabbá válik (legalább is kívülről, mind a fönntartó, mind pedig a fölhasználok számára).

- Az atlanti rendszerben az irányítás decentralizáltabb és részben piaci ösztönzőket használ. Az atlanti rendszerben múködő szervezet - akár akarja, akár nem - a helyi társadalomra nyitottabb. A benne zajló spontán folyamatok ezért hamarabb válnak nyilvánosakká. Nehezebb a szervezeten belül tartani és menedzselni őket, kitettebb a fölhasználóknak és a (helyi) fenntartóknak.

Ezek persze csupán nagyon általános következtetések. Az iskolákban folyó spontán folyamatok rendkívül változatosak. Csak akkor érthetjük meg őket, ha az iskola mindkét kötöttségét figyelembe vesszük: függőségét székhelyének társadalmától, illetve attól, hogy milyen oktatási rendszerbe tartozik. Ez ennek a nevelésszociológiai áttekintésnek a legfontosabb tanulsága.

\section{Jegyzetek}

1 Nagyszervezeten a bonyolult szervezeteket értjük, amelyek hierarchikusan épülnek föl, bonyolult célok és érdekek kötik össze a benne múködőket. Iskolarendszernek nevezzük az egymás után következő szintű és típusú iskolákat, amelyeket el kell végezni a gyereknek ahhoz, hogy továbbtanulhasson. 


\section{Irodalomjegyzék}

\section{Felhasznált irodalom}

Archer, M. S. (1984): Social Origins of Educational Systems. (Az oktatási rendszerek társadalmi eredete.) Sage, London.

Kozma Tamás (2001): Bevezetés a nevelésszociológiába. Nemzeti Tankönyvkiadó, Budapest.

Kozma Tamás (2006): Az összehasonlító neveléstudomány alapjai. Új Mandátum Könyvkiadó, Budapest.

Mead, M. (1970): Culture and Committment. The American Museum of Natural History, Washington.

Meusburger, P. (1998): Bildungsgeographie. Spektrum, Heidelberg, Berlin.

Polónyi István (2002): Az oktatás gazdaságtana. Osiris Kiadó, Budapest.

Schultz, Th., W. (1971/1983): Beruházás az emberi tőkébe. Közgazdasági és Jogi Könyvkiadó, Budapest.

\section{Ajánlott irodalom}

Bábosik István és Kárpáti Andrea (2002, szerk.): Összehasonlító pedagógia. BIP, Budapest.

Báthory Zoltán és Falus Iván (1997, főszerk.): Pedagógiai Lexikon I-III. Keraban, Budapest. (vonatkozó szócikkek)

Benke Magdolna (2014, szerk.): Learning Regions. Hungarian Educational Research Journal 3, 3. Doi 10.14413/ HERJ2014.03

Delors, J. (1997, szerk.): Oktatás - rejtett kincs. Osiris Kiadó, Budapest.

Fehérvári Anikó (2014): Szakmai képzés és társadalmi átalakulás. Új Mandátum Könyvkiadó, Budapest.

Forray R. Katalin és Kozma Tamás (2011): Az iskola térben, időben. Új Mandátum Könyvkiadó, Budapest.

Halász Gábor (2001): Az oktatási rendszer. Műszaki Könyvkiadó, Budapest.

Kozma Tamás és Sike Emese (2004, szerk.): Pedagógiai informatika. Kossuth Egyetemi Kiadó, Debrecen.

Kozma Tamás és Pusztai Gabriella (2015, szerk.): A PISAjelenség. Educatio, 23, 2 (tematikus szám) 
Mátrai Zsuzsa (1991, szerk.): Tanterv és vizsga külföldön. Akadémiai Kiadó, Budapest.

Mátrai Zsuzsa (2001): Érettségi és felvételi külföldön. Műszaki Kiadó, Budapest.

Pusztai Gabriella (2011): A láthatatlan kéztől a baráti kezekig. Új Mandátum Könyvkiadó, Budapest.

Vári Péter és mtsai (2001): A PISA vizsgálat. OKKER, Budapest. Zsigmond Anna (2005): Amerika: Társadalom és oktatás. Gondolat Kiadó, Budapest. 



\section{BORECZKY ÁGNES}

\section{Családkutatások nevelésszociológiai nézőpontból}

Nevelésszociológiai nézőpontból a család mint társadalmi intézmény, mint a szocializáció elsődleges színhelye fontos. Az, hogy miként határozzuk meg a család fogalmát, hogy miként fogalmazzuk meg a család és a társadalmi környezet viszonyát, hogy mennyire vesszük komolyan a családi formák és a szocializációs rendszerek társadalmi-kulturális sokféleségét, vagyis hogy miként gondolkodunk a családról, és hogy mindez milyen gyakorlati következményekkel jár az iskola és a család kapcsolata, valamint a tanári munka szempontjából, eddig szinte teljesen kimaradt a nevelésszociológiai diskurzusokból.

Ebben a fejezetben ezért arra törekszünk, hogy bemutassuk a családfelfogás változásait és azok hatását a szocializáció kontextusának és elemeinek teoretizálására. Különös figyelmet szentelünk a nukleáris család ${ }^{1}$ elméleteinek, mert úgy véljük, hogy a pedagógiai gyakorlatban a nukleáris családforma idealizálása és túláltalánosítása hordozza a legtöbb kockázatot.

\section{Bevezetés}

A család mindenkinek mást jelent. Van, akinek közvetlen hozzátartozóit, a szüleit és testvéreit, másnak velük együtt a nagyszülőket, esetleg a tágabb rokonság egyes tagjait is. De a család jelentése térben és időben is változó: mást jelentett és jelent koronként, földrajzi régiónként, társadalmanként, társadalmi csoportonként/kultúránként, és eltérő definícióval dol- 
goznak a különböző tudományágak is, mint pl. a szociológia, a statisztika vagy a néprajztudomány.

A család szociológiai megközelítésben olyan társadalmi intézmény, amely a generációk közti folytonosság megteremtésével számos, a társadalom múködéséhez és az egyén boldogulásához elengedhetetlen tudást, tapasztalatot, mintát, érték- és szerepkészletet stb. közvetít és hagyományoz. Más megfogalmazásban azt is mondhatjuk, hogy az egyén világról alkotott képe jelentős mértékben egy, a családtagok által közvetített és belsővé tett (internalizált/interiorizált) valóság, melyet a későbbi hatások, egyéni tapasztalatok átszíneznek vagy át is írhatnak, sőt meg is kérdőjelezhetnek, de amelynek hatását semmiképpen sem érvénytelenítik. Általánosabb értelemben ezt nevezzük primér (elsődleges) szocializációnak, és ez az, amiért a nevelésszociológia a családdal, a család szerepével foglalkozik.

A család mai, szociológiai fogalmát Andorka Rudolf (2006) szerint az jellemzi, hogy kiscsoport, melynek tagjait házassági vagy vérségi (ritkábban örökbefogadással létrejött) kapcsolat köti össze. A kiscsoport jelleg különbözteti meg a néprajz tágabb családfogalmától ${ }^{2}$, a házassági-vérségi kapcsolat pedig a nem szükségképpen rokoni szálakkal egymáshoz fúződő emberek alkotta háztartástól ${ }^{3}$ (egyes történeti iskolák megnevezésében a háznéptől). A fenti meghatározáshoz hozzátehetjük, hogy a család egy, a társadalommal folyamatos kölcsönhatásban működő rendszer, mely mint valamennyi rendszer határokkal és sajátos múködéssel rendelkezik, s melynek részei (tagjai) is állandó hatást gyakorolnak egymásra.

Fedjen bármit is a családfogalom, az emberi együttélési formák minden korban és mindenhol nagy változatosságot mutatnak. Mindig voltak egyedülállók, mindig voltak egyszülős családok, mindig voltak kis és nagy, két- és többgenerációs családok. Ugyanakkor a társadalmi változások hatást gyakorolnak 1. az eltérő együttélési formákhoz való viszonyra, és ennek következtében a megnevezésekre, 2. az egyes együttélési formák gyakoriságára, illetve arra, hogy 3. dominánssá válik és egyben normativizálódik-e pl. a szülőkből és gyerekekből álló kiscsalád, vagy éppen ellenkezőleg, gyengülnek a családfelfogást homogenizáló társadalmi elvárások. 
Jól ismert a sokszor szánakozással, néha gúnnyal emlegetett agglegény, öreglegény vagy vénkisasszony kifejezés. Ma már valamennyi irodalmiasnak hangzik, helyettük gyakran éppenséggel ellenkező előjellel a szinglit használjuk. Irodalomból ismertek azok a történetek, amelyek háborúk, betegségek stb. miatt megözvegyült, majd újraházasodó anyákról-apákról szólnak, s velük sajnálatra méltó árvákról, és/majd többnyire gonosz mostohákról és mostohatestvérekről. Az egyik házastárs halála következtében kialakuló családot ma is részvét övezi. Ez azonban nem változtat azon, hogy az egyszülős családokat általában drámaian csonka vagy (kevésbé durván) töredék családnak nevezik, az újraházasodott szülőkből és gyerekeikből álló új egységet pedig mostoha, helyreállított, kompozit, mozaik, illetve patchwork családnak. Míg előbbi mindkét formájában negatív, illetve pejoratív tartalmú értéktelített fogalom, egyfajta minősítés, utóbbiak (a mostoha család kivételével) szemantikailag inkább semleges vagy pozitív, az esztétikumot sem kizáró, komplexebb tartalomra utalnak.

$\mathrm{Az}$ együttélési (család- és háztartásszerkezeti) formákat ${ }^{4}$ nagyon sok tényező befolyásolja. A nagyobb és a helyi (lokális) társadalom hatása mellett szerepet játszik a család gazdasági-társadalmi helyzete és beágyazottsága is, de változik, hogy kivel élünk együtt az egyéni és a családi élet szakaszai szerint is. (Hareven, 1978, 2000).

A nagyobb társadalom, nevezetesen az eltérő társadalomfejlődés hatását illusztrálják a történetileg eltérő együttélési mintázatok. Hajnal (1983) például a háztartásokon belül elkülönít egy európai (észak)nyugati modellt, amelynek alapját már az ipari forradalmat, vagyis a 18-19. századot megelőzően az idősebb korban kötött házasság és döntően a nukleáris családforma jellemezte. A magyar családtörténeti kutatások (Andorka és Faragó, 1984; Andorka, 2001) azt bizonyítják, hogy Kelet-Közép-Európa köztes régió volt: a többgenerációs „nagycsalád” gyakoribb volt, mint Nyugaton, de ritkább, mint Kelet-Európában.

A modernizációhoz kapcsolódó társadalmi változások és együttélési formák alakulását ${ }^{5}$ elemzi Tomka Béla (2000) Családfejlődés a 20. századi Magyarországon és Nyugat-Európában címü könyvében ${ }^{6}$, a lokális minták és a családciklusok ha- 
tását egy 2001 és 2004 között folytatott hazai kutatás eredményei példázzák (Boreczky és mtsai, 2007). Ezek szerint a vidéki és a városi családok szerkezete még néhány évvel ezelőtt is jelentősen különbözött egymástól. A kiterjedt család leggyakoribb a falusiak, legritkább a budapestiek családjaiban volt. A házasságkötéskor sok fiatal szüleivel együtt maradva vagy szüleihez visszaköltözve kezdi közös életét, de a települési különbségek ekkor sem veszítenek jelentőségükből: anyjukkal, testvéreikkel legtöbben a falusiak, legkevesebben a budapestiek közül maradnak együtt.

A nukleáris család a politikai-ideológiai viták visszatérő témája, normává a 19. században lett, normativitása azonban az együttélési formák pluralizálódásával, a házasság nélküli együttélések elfogadásával és a heteroszexuális kapcsolatok egyedüli létjogosultságának megkérdőjelezésével erősen meggyengült.

A maihoz sok szempontból hasonló családkép a felvilágosodás idején kristályosodott ki, és azzal párhuzamosan az individualizáció felerősödésével problematizálódott. Ennek ellenére a 19. század folyamán a polgári, viktoriánusnak vagy biedermeiernek nevezett családideál alapvető szerephez jutott. Ez, a ma hagyományosnak tekintett család mereven kijelölte a nemek, valamint a felnőttek és a gyerekek közötti határokat, továbbá szilárd elvárásokat támasztva alakította az erkölcsöt, az értékeket, a vallásos hitet, a kötelezettségeket és elköteleződéseket. A szülők azt gondolták, hogy felelősek gyerekeik jóllétének biztosításáért, ez azonban elsősorban az iskoláztatás iránti felelősségérzetet jelentette (Berger és Berger, 1983).

Jóllehet a 19 század végére a polgári családideál veszített erejéből ${ }^{7}$, a II. világháború után átalakult formában ugyan, de hosszú évtizedekre újra normává lett. Parsons (1955) szerint a rokonságról, a rokoni kötelékekről levált nukleáris család a modern ipari társadalmak, a földrajzilag és társadalmilag is mozgásképes személyiség kialakulásának alapja. A premodern társadalmak rokonsági rendszeréhez képest a kiscsalád kevesebb funkcióval rendelkezik. Talcott Parsons két alapfunkciót tulajdonít neki, a primér szocializációt és a felnőtt személyiség stabilizációját, mely utóbbi részint a házastársak, illetve a család feszültségoldó, feszültséglevezető interakcióin keresztül valósul meg. 
A funkcionalista felfogásban a család egymást kiegészítő szerepeivel a társadalom kicsi és erősen differenciált alrendszere, mely maga is alrendszerekből áll, és interakciók révén kapcsolódik a társadalom többi alrendszeréhez, például a gazdasági, oktatási, vallási, egészségügyi stb. intézményekhez, melyek korábbi funkcióinak egy részét is ellátják.

Parsons elméletében a család közvetítő kapocs az egyén és a társadalom között. A szülői szerepeket a professzionalizálódás, és akár a nagyobb társadalmat, sajátos munkamegosztás jellemzi: az apa a munkavállaláshoz szükséges instrumentális, az anya az otthonteremtéshez, törődéshez, a gondoskodáshoz, gyerekneveléshez szükséges expressziv (érzelmi) szerep megtestesítője. A gyerekek így az elsődleges szocializáció során hatékony, a nagyobb társadalom által feltételezett (mai kifejezéssel társadalmilag megkonstruált) nemi szerepeket sajátítanak el ${ }^{8}$.

A nukleáris család sikertörténetébe a hatvanas években disszonáns hangok keveredtek, a norma erodálódni kezdett, majd maga is kérdésessé vált, mi több, a keményebb megfogalmazások egyenesen a fehér elnyomás vagy az egyenlőtlenségek átörökítésének egyik eszközeként jelenítették meg. A hatvanas évek önmagában sem szelíd kalicka és börtön metaforáit a hetvenes évekre felerősítette a feminista kritika, mely szerint a család patriarchális elnyomó intézmény, mely a nőket háziasszony szerepre kényszeríti, korlátozza szabadságukat és munkavállalási lehetőségeiket, és kérdésessé vált a család tisztán heteronóm felfogása is. A posztmodern álláspontokban a családtípusok sokfélesége, az egyének érték- és identitásválasztásának szabadsága, a narrativák egyéni és családi identitást teremtő ereje került előtérbe.

\section{A család funkciói és a szocializáció}

Számba vehetnénk a család számos funkcióját, így pl. a reprodukciós, gazdasági, érzelmi, irányító-ellenőrző, státuskijelölő, gondozó stb. funkciót ${ }^{9}$, mivel azonban mind szorosan összefügg a tágabban értelmezett szocializációval, sőt, több része annak, ez utóbbira koncentrálunk. Állításunk azon a tényen alapul, hogy a család igen összetett, személyek közötti rend- 
szer és müködési mechanizmusai hatástalanok maradnának, ha változékonysága mellett nem biztosítaná a stabilitást, ha a személyek közti viszonyokat nem szőnék át érzelmek, ha nem lennének szabályok és azok betartását senki sem ellenőrizné vagy (és ez ugyan az egyenlőtlenségek társadalmi átörökítése, illetve a társadalmi mobilitás szempontjából valamivel problematikusabb), nem játszana meghatározó szerepet a gyerekek életpályájának, társadalmi státushelyzetének az alakulásában.

Anthony Giddens megfogalmazásában a szocializáció „„az a folyamat, amelynek során a tehetetlen csecsemő fokozatosan öntudattal bíró és értelmes személyiséggé válik, aki feltalálja magát abban a kultúrában, amelybe beleszületett. ${ }^{10} \mathrm{~A}$ fiatalok szocializációja a társadalmi reprodukció általánosabb jelenségét is erősíti, azt a folyamatot, amelyben létrejön a társadalom időbeli strukturális folytonossága." (Giddens, 2008:134-135) Más nézőpontból úgy is fogalmazhatunk, hogy a szocializáció során a fontos személyekkel (szignifikáns másikkal) való azonosulás és az általános másikon (generalizált másikon) keresztül a külső valóságot saját belső valóságunkká alakítjuk, miközben értelemszerűen a világhoz való viszonyulásunk is formálódik (Mead, 1973; Berger és Luckmann, 1998). A hivatkozott nézetek azt sugallják, hogy a szocializációt nem lehet a normák és értékek tanulására, a hagyományok, szokások, szabályok és cselekvésmódok stb. átörökítésére szúkíteni. ${ }^{11}$ Már csak azért sem, mert a család a maga bonyolult rendszerével és folyamatos interakcióinak sokaságával szüntelenül hat minden tagjára.

A családfelfogáshoz és a családszerkezethez hasonlóan a szocializációs folyamat is eltérő körülmények között zajlik és eltérő jellegzetességekkel bír a különböző társadalmakban, társadalmi/etnikai csoportokban, kultúrákban. A példákért nem kell messzire mennünk, elég, ha meghallgatjuk nagyszüleink gyermek- és ifjúkoráról szóló történeteket, és összehasonlítjuk a sajátunkkal, hogy érzékeljük a szocializáció és a társadalmi-kulturális különbségek összefüggését. Utóbbiról nem is igen választható le, mert minden kultúrának megvan(nak) a maga sajátos szocializációs rendszere vagy rendszere(i), melyek nagyon sok elemből tevődnek össze. Ilyen pl. megszámlálhatatlan direkt vagy indirekt értékmozzanatot közvetítő családi hierarchia, a tekintélyi rendszer és személyek, a szerepek, a 
szabályok, a kontroll, a nyelv és a kommunikáció, a konfliktusmegoldás stb., de ilyen maga a család nagysága és szerkezete is. Már csak ezért is féloldalasak azok a szocializációs elméletek, melyek (elsősorban a középosztálybeli) nukleáris család normalizálódását támogatva évtizedeken át annak szocializációs sajátosságait foglalták keretbe, és minden más családtípust, minden más szocializációs formát marginalizáltak, elmaradottnak tekintettek vagy a gyerekek iskolai előmenetele és későbbi pályája szempontjából hátrányos helyzetűnek minősítettek. Jó példa erre, hogy számos kutatás a szülői attitűdök, a szülői kontroll, az érzelmek, a bevonódás és a gyerek viselkedése közti összefüggések feltárására irányult, a nagyszülők vagy a rokonság más tagjainak lehetséges szerepe ebből a szempontból fel sem merült. De utalhatunk a rétegspecifikus szocializációs kutatásokra vagy az iskolai eredményességet a tanulók családjának szocioökonómiai státusával magyarázó megannyi vizsgálatra, mely a család társadalmi státusát évtizedeken keresztül kizárólag az apa iskolai végzettsége/foglalkozása alapján értelmezte. Sőt, akár Bernsteinre is (lásd a Nevelésszociológiai problémakörök és nézőpontok c. fejezetet), aki az iskolai teljesítmények, illetve az esélyek különbségét a családban tanult nyelvvel/kommunikációs kódrendszerrel hozta összefüggésbe, azt pedig a családszerkezet rétegspecifikus voltával. A kétféle kódrendszer elsajátítását kétféle családtípus múködéséhez rendelte, a munkásosztálybeli pozicionális, illetve a középosztálybeli személyorientációjú családhoz. A pozicionális családban a szerepek mereven elkülönülnek egymástól nem, életkor és a családban betöltött pozíció szerint, vagyis mindenkinek kijelölt szerepe van. A személyorientációjú családban a szerepek felcserélődhetnek, ehhez azonban a szerepek és feladatok folyamatos egyeztetésére van szükség, ami pedig azt feltételezi, hogy a családtagoknak meg kell fogalmazniuk saját helyzetüket, személyes szükségleteiket. Bernstein a pozicionális családok esetében a nagyszülőkkelrokonokkal való gyakoribb érintkezésről ír, a középosztálybeli, azaz az iskolai eredményesség szempontjából sikeresebb gyerekek családját viszont egyértelműen nukleáris családként írja le. Ezzel azt implikálja, hogy részint a családszerkezeten és a szerepeken keresztül történik az egyenlőtlen társadalmi esé- 
lyek átörökítése, valamint, hogy a magasabb státus eléréséhez szükséges iskolai versenyben a pozicionális családban felnövő munkásosztálybeli gyerek eleve hátránnyal, a személyorientált (kis)családban nevelkedő középosztálybeli gyerek pedig előnynyel indul.

\section{Korábbi és mai családelméletek}

Az 1960-as, 1970-es évek családtörténeti-családszociológiai kutatásaiban két nagyobb, egymással csak kevéssé érintkező vonulat vált meghatározóvá. Peter Laslett nyomán a család- és háztartásnagyság történeti alakulásának kiterjedt vizsgálata alkotta az egyik vonulatot, a másik, Anderson kifejezésével „érzelmi” irányzatnak (sentiments approach) Aries munkássága lett a kiindulópontja, aki a családfogalomra, a család és a külső világ közti kapcsolatra, illetve a családi élet belső átalakulására vonatkozó kutatások sokaságát indította el.

A diskurzus a patriarchális nagycsalád és a konjugális család alapú háztartás ${ }^{12}$ történeti dominanciája és átalakulása, a nukleáris kiscsalád univerzalitása, illetve az idealizált hagyományos családi élet realitása körül folyt, az érzelmekre vonatkozó kutatások középpontjában pedig az érzelmek hiánya, a ridegség, illetve az intimitás történetisége állt.

Bár Laslett család- és háztartásrekonstrukciói ${ }^{13}$ után alapos érvek szóltak amellett, hogy a kiscsalád nem csupán az iparosodás és a modernizáció családszervezeti formája, a hetvenes évekig - nem utolsósorban Parsonsra alapozva - a nukleáris család és a modernitás lényegében rokonfogalmakként szerepeltek.

\section{Család és háztartás}

Laslett cáfolta azt az elterjedt nézetet, mely szerint, az ipari forradalom előtt uralkodó családforma a kiterjesztett család volt, de vitatta azt is, hogy a nukleáris család elterjedése az iparosodás, a modernizáció következménye lenne, mivel Angliában már jóval korábban, a 17. századtól a leggyakoribb családforma volt. Laslett gondolatai világszerte visszhangra és 
követőkre találtak (Armstrong, 1972; Goode, 1972; Greven, 1972; Hammel, 1972; Nakane, 1972; Wall, 1972; Andorka és Faragó, 1984; Andorka, 2001), végül is a nukleáris család univerzalitásának új tudományos paradigmájához vezettek ${ }^{14}$.

Ugyanebben az időszakban a családra és a rokonságra vonatkozóan nem egy történész, társadalomtörténész, szociológus egymáshoz hasonló következtetésre jutott, nevezetesen arra, hogy a család a modernizáció során nem vált elszigetelt egységgé, hogy az iparosodás, a városiasodás és az individualizáció nem idegenítette el szükségképpen a rokonságtól, hogy a tágabb család a "modern időkben” is fontos szerepet játszik még akkor is, ha a különböző generációk nem élnek együtt, és a család és a rokonság funkciója folyamatos változásban van.

A külön háztartásban és nem egy helyen élő család és rokonság kapcsolatának leírására számos új fogalom született. Anderson (1971) a funkcionális interakció fogalmát használta. Litwak a módositott kiterjesztett család fogalmát vezette be. Szerinte a nukleáris családok külön laktak egymástól, de aktívan együttmúködtek azokban a helyzetekben, melyekben családi vagy intézményi segítségre volt szükség. Hasonlóképp - valamivel később ugyan, de - Cressy a nem együtt élő rokonságon belül megkülönböztette az aktiv és hasznos rokoni kötelékeket (Cressy 1986), Levi (1990) pedig a valódi és a fiktiv rokonság gondolatát, illetve funkcióját.

A nukleáris család alapú háztartásokra vonatkozó koncepciók érvényességét közvetlenül kérdőjelezte meg Ruggles, aki szerint Amerikában és Angliában is a huszadik század előtt a nagycsaládon belül az ún. törzscsalád (stem family sytem) ${ }^{15}$ volt a jellemző (Ruggles, 1987, 1994). A többféle minta egyidejű létezését bizonyította Gillis, mikor az udvarlási és házassági szokások regionális sokféleségéről írt, illetve arról, hogy maga a házasság is a nagyobb rokonság fontosságát erősíti meg (Gillis, 1985).

A különböző régiókra, országokra és időszakokra vonatkozó, a család egyidejű sokféleségének tényét bizonyító történeti és szociológiai kutatások, a kiscsalád univerzalitásának és mítoszának problematizálása ellenére, az a nézet, hogy a nukleáris család egyszerre oka és következménye az iparosodásnak, a városiasodásnak és az individualizációnak, így tehát a 
modernizációnak (és mint ilyen a szocializáció szempontjából a legelőnyösebb családszerkezeti forma), továbbra is erősen tartotta magát.

Az 1980-as, 1990-es évekre felerősödő kritikai megközelítések végül is több ponton megkérdőjelezték a nukleáris családra, illetve az egyszerű háztartásokra épülő modell kiterjesztését minden társadalomra (Anderson, 1995; Mitterauer, 1992), és végül megingatták a nukleáris kiscsalád szociológiai mítoszát is. Az áttörést jól reprezentálja a Blackwell Companion to the Sociology of Families (2004) címú gyűjteményes kötet. A bevezetőben a szerkesztők ezt írják: „Senki sem olvashatja el a kötetet úgy, hogy nem vesz tudomást a család változásáról és nem tudatosítja az egyre változatosabb családformákat. Valójában, maga a cím, a Családok szociológiája szándékosan kerüli a nagybetűs Család statikus és univerzális fogalmát. A cím elismeri a családformák pluralitását, és implikálja a család formálódásának és felbomlásának időbeli dinamikáját (Scott, Treas és Richards, 2004, xvii.).

A kötet szerzői számára mind a család sokfélesége, mind komplexitása evidencia. A vita a családszerkezetről és a család funkcióiról (a család hanyatlását is beleértve) természetesen nem ért véget, de azok a kutatások, amelyek a térben és időben egymást mellett létező családtípusok és a rokonság továbbélő funkcióinak elméleteire épültek, végül utat törtek maguknak és polgárjogot nyertek a fóáramú társadalomtudományi gondolkodásban. Mi több, a kritikai megközelítések mintha rendszerbe is szerveződnének.

\section{A családi intimitás-érzelmek}

A kutatások - a családszerkezeti iránytól jobbára elkülönült másik ága, a történeti szociológia vagy társadalomtörténet, a mentalitás, illetve a gyerekkortörténeten belül a családi élet átalakulását vizsgálta. A leghevesebb vitát Aries híres könyve, a Gyermek család, halál gerjesztette, ez a családi élet alapvonásainak állandósága, illetve történetisége, továbbá a szülők gyermekeik iránti közönye, és ezzel összefüggésben az egyes korszakok gyerekképe körül folyt (Aries, 1987; Pollock, 1983; 
Shahar, 1990. Hasonlóképp a család- és háztartásszerkezeti kutatásokhoz, a problémát itt is részben Aries tételeinek túláltalánosítása, dogmatikus értelmezése, nem egyszer félreértése okozta. A házaspárok közötti intimitás, a közöny és a szülői szeretet körüli ellentmondásos kutatási eredmények után (Badinter, 1999; Pollock, 1983; Shahar, 1990; Péter, szerk. 1996; Szabolcs, 1995; Pukánszky, 2001) a viták lecsendesültek. Mára nyilvánvalóvá vált, hogy többféle minta is létezhet egymással párhuzamosan, hogy pl. a negatív és a pozitív gyerekkép egy időben és folyamatosan is létező hagyomány, a gyermekkel kapcsolatos alapvetően különböző megközelítések (bűnösség - ártatlanság, tisztaság stb), a közöny és a törődés (szigor, fegyelmezés-bensőséges szeretet), a korai felnőtté válás, illetve a gyermekkor társadalmi realitása nem zárják ki egymást.

\section{Új irányok a család és a szocializáció kutatásában}

A kutatási irányokban az 1980-as évek végén bekövetkezett fordulat a családkutatásokat sem hagyta érintetlenül. A család és a társadalmi környezet közötti többirányú és többszintű viszonyt, a család összetett belső világát, müködésének rejtettebb mintázatait nem lehetett már egy tudományág konvenciói és fogalomrendszere szerint értelmezni. Az újabb kutatások így nemcsak szétfeszítik, át is lépik az egyes tudományterületek határait, és sajátos módon ötvözik többek között a demográfiát és/vagy a társadalomtörténetet a szociálpszichológiával, antropológiával vagy a narratív pszichológiát a szociológiával. Az elméletekben és a fogalmakban vissza-visszatérő szóképző lett a kapcsolatokra utaló „inter-...” kifejezés (interdiszciplinaritás, intergenerációs család, intergenerációs én).

Az újabb kutatások új megvilágításba helyezték a modernitás és a tradíció viszonyát, kitágították a családi rendszer, a szocializáció értelmezési körét és olyan újabb területeket kapcsoltak hozzá, mint a globalizáció és a lokalitás, az identitás, a mintázatok örökítése és változása, ugyanakkor segítségükkel láthatóvá lettek a családon belüli folyamatok, az egyéni fejlődés és a narratívák főbb témáit szervező tágabb kultúrához való kötődés összefüggései is. Valamennyi kutatási irány új 
vagy átértelmezett felfogást sugall, és a család társadalmikulturális beágyazottsága, külső-belső kapcsolatrendszere, az interakciók tartalma és minősége, a családi narratívák, a családtörténet irányába finomítja, illetve írja át a család- és a szocializációs elméleteket.

Az eltérő családmodellek és mintázatok szinkronitása képezi a pszichológus Kagitcibasi (2003) társadalomtörténetimentalitástörténeti-szociológiai és pszichológiai elemekre épülő család- és szocializációs modelljét. A nyugati prototipikusnak tartott családtípust az individualitás és a modernitás ethoszából eredezteti, ennek kritikájaként a család társadalmi és pszichológiai jellemzőit is figyelembe véve három modellt dolgozott ki, mind különböző társadalmigazdasági-kulturális kontextusban múködő családi rendszer. A családon belüli kölcsönös függöség hagyományos társadalmakban jellemző és individualitást hangsúlyozó függetlenség tipikus modelljei mellett megnevez egy harmadikat is, a kölcsönös érzelmi függőség modelljét, utóbbit egyben a változás és kultúrák közti közeledés modelljének is tekinti.

Duke (2005) a család adaptációjára ható legfontosabb tényezőket figyelembe véve az amerikai Emory Központ MARIAL (Myth and Ritual in American Life) interdiszciplináris (teológia, antropológia, szociológia, pszichológia stb.) vizsgálatainak egyik zárótanulmányában a következő modellt állította fel:

1. ábra. A család reflektivitásának integrativ modellje

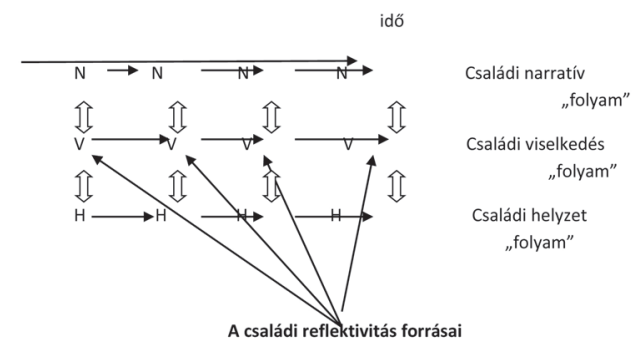

Hit, mítoszok, történetek, kultúra, közösség, pszichológiai tényezők, családtörténet, hely, gazdasági tényezók stb. 
Duke szerint a „családok között különbségek vannak abban, hogy az egymást követő helyzetek áradatára folyamatosan milyen válaszokat adnak. Egyesek formális és széles körben alkalmazott megoldásokat választanak, mások egyéni rituálékat. Egyesek pszichológiai intra- és interperszonális eszközökhöz nyúlnak, megint mások a közösséghez fordulnak támogatásért. ...a családi narratívák maguk is segíthetik a családokat az élethez való alkalmazkodásban." (Duke, 2005:2-22.)

Edgar (2004) pl. a globalizált világ, a közösség és az egyén közti viszonyrendszerbe helyezve a családot, azt állítja, hogy annak alapvető közvetítő (mediator) szerepe van. Edgar szerint a család a növekvő számú városi népesség környezetében is elosztja a rendelkezésére álló forrásokat, újraépíti a társadalmi tőke felhalmozásához és átörökítéséhez szükséges kapcsolatokat. Crow és Maclean (2004) a globalizáció, az individualizáció és korábbinál nagyobb mobilitás ellenére ugyancsak a családok és a helyi közösségek közötti kapcsolat jelentőségét emeli ki, egyrészt arra hivatkozva, hogy a földrajzi távolság nem szükségképpen akadályozza a családi-rokoni kapcsolatok fenntartását, másrészt, hogy kutatási eredményeik szerint a családok nem is törekszenek a teljes függetlenségre, s továbbra is pozitívan értékelik a lokális közösséghez tartozást.

A lokalitás és a többgenerációs családi hatásrendszer együttes jelentőségét konceptualizálva újabb-régi értelmezési területet jelölnek ki azok a családtörténeti kutatások, melyek az egyéni életutat, az egyén életében bekövetkezett változásokat a családi rendszeren belül, illetve a család és a lokalitás együttesében értelmezik (Bertaux és Thompson, 1997).

Demográfia és szociálpszichológia kapcsolódik össze Mabry, Giarusso és Bengston (2004) elméletében. Kutatásaikban a szerzők a generációk közötti kapcsolatok vizsgálatát helyezik a középpontba, a megváltozott helyzetre utalva pedig az intergenerációs családok fogalmat használják. A megváltozott helyzet, az egyre hosszabb életkor és az alacsony gyerekszám, mely a családok változó szerkezetében is tükröződik, de a demográfiai tényeken túl részben abból is ered, hogy a válások után alakuló mozaik családok új rokonsági viszonyokat eredményeznek (több apa-anya, nagyszülő stb.). Eredményeik szerint, bár mind a generációk közötti kapcsolatok szerkezete, 
mind az interakciók megváltoztak az elmúlt évszázad során, jelentőségük a 21. század elejére inkább nő, mint csökken, mert a család továbbra is a társas élet alapintézménye, az egyének jóllétének, a gyerekek és öregek iránti gondoskodásnak, törődésnek az elsődleges forrása. A kapcsolatok leírására egy hatdimenziójú szolidaritás modellt használtak, és ebből öt dimenzióban realizálódó interakciókat találva, arra a következtetésre jutottak, hogy Amerikában a felnőtt gyerekek több mint ötven százalékának „szorosra kötött” kapcsolatai vannak a szüleivel. A családon belüli szolidaritás, a generációk közti kapcsolatok reciprok rendszere kiterjedt kutatási területté vált.

Talán nem kell külön hangsúlyozni, hogy az újraértelmezett kapcsolatrendszerek és rokonsági hálózatok a szocializációs színterek, valamint számos eleme (értékek, interakciók, identitások stb.) számára új keretet teremtenek. Ha ugyanis a gyerekek (akár csak az egyik szülővel) olyan családban élnek, melyben többé-kevésbé rendszeres interakciók és tranzakciók vannak a rokonságon belül, hatásukat a szocializációra, különösen az elsődleges szocializációra nem lehet figyelmen kívül hagyni ${ }^{16}$. A generációk közötti kölcsönös segítségnyújtás során a nagyszülők vagy más rokonok a gyerekek életének részévé válnak, és fordítva, a gyerekek jutnak szerephez nagyszüleik vagy más rokonaik életében ${ }^{17}$. A szocializáció szemszögéből mindez azt jelenti, hogy a gyerekek a szüleiké mellett más élettapasztalatokkal, élményekkel, értékekkel és mintákkal is találkoznak, a szignifikáns másik múltjának valóságát mint alternatív realitást pedig beépítik. Adott élethelyzetben ez belső konfliktushoz vezetne, a különböző valóságokat tehát összhangba kell hozni egymással, azaz szinkronizálni kell. A szinkronizáció kulcsfogalom az időszociológiai megközelítések perspektívájából is, amennyiben a szocializáció egyik alapvető funkciója az, hogy az egyén képessé váljon a különböző idők szinkronizálására, harmonizációjára (Hall, 1983; Meleg, 2006).

A narratív vizsgálatok korábban láthatatlan területekre irányították a figyelmet. A rutinok és rituálék megfigyelésén keresztül feltárták, hogy a családi beszélgetések miként befolyásolják a gyerekek szociabilitását és adaptivitását, miközben rámutattak a családi és a nemi szerepek megvalósításában és áthagyományozásában, a beszélgetésekben való részvételben, 
valamint a napi és a múltban történt események témáiban megjelenő kulturális különbségekre (Blum-Kulka, 1997; Fiese, 2006).

Pratt és Fiese (2004) a történetmondás három funkcióját különbözteti meg: magát a mesélést, melyen keresztül a gyerekek maguk is elbeszélővé válnak, a történetek tartalmát, azokat az üzeneteket, amelyeket közvetítenek és azt a szerepet, amit a személyes identitás kialakításában játszanak. A történetek az egyéni és a családi élet különböző szakaszaiban más-más funkcióval bírnak és idők során maguk is változnak. Nemcsak közvetítők az egyén és a család által belakott világ között (az egyén a családi percepció lencséin keresztül látja a világot), leckét adnak a moralitásról, a sikerekről és veszteségekről, követendő és elkerülendő utakról, és mivel az identitás alapját képezik, erősítik a családi kohéziót is.

Az énfejlődés és a családi interakciók összefüggését elemezve a mai kutatások egy része a személyes történetet és identitást a családi történetekbe, illetve a szülők történeteibe fúzve kitágította az én értelmezési tartományát. Fivush, Bohanek és Duke kutatási eredményei azt bizonyítják, hogy a saját család történetének ismerete befolyásolja az önbecsülést, önmagunk jobb megértéséhez és jólléthez vezet. Úgy tűnik, hogy a személyes múlt és a családtörténetben elfoglalt hely által egyaránt definiált intergenerációs én (intergenerational self) védőfaktorként múködve növeli a rezilienciát később is, amikor a gyerekek már felnőttek. „A családtörténetek elmondásán és megosztásán keresztül a gyerekek az előző generációkhoz kötődve érzékelik saját énjüket. Azáltal, hogy az ember lehorgonyozza magát a családtörténetbe, biztonságérzete támad és érzékeli a helyet, mindez pedig segíti az önbizalom és az énkompetencia kialakulását." (Fivush, Bohanek és Duke, 2005:9) Egy korábbi narratívakutatás során az is kiderült, hogy azok a gyerekek, akik olyan családokban nőnek fel, amelyekben nyíltan és következetesen beszélnek a múlt kritikus, érzelmileg megterhelő eseményeiről, jobban meg tudnak birkózni a saját helyzetükkel is (Fivush, Bohanek és Robertson, 2004).

Az ismertetett kutatások - egy-két kivétellel - nem nagyon érintették meg a hazai családkutatásokat. Kivételt képez egyegy olyan önmagában álló munka, mint például H. Sas Judit 
Szubjektiv történelem vagy Somlai Péter Húsz év c. könyve, mindkettő a család szimbolikus világának értelmezéséhez közelít (Sas, 1995; Somlai, 2001). És ritka kivétel Losonczi Ágnes könyve, a Sorsba fordult történelem (Losonczi, 2005) is. Losonczi - akár Sas Judit - hosszabb távon vizsgálja a történelmi események, társadalmi traumák hatását a családokra, a család tagjainak pályájára, és miközben azokat a nagyobb családi rendszerbe illeszti, a kapcsolódó történetek, megélttovábbörökített és elhallgatott múlt segítségével szintén a család szimbolikus funkciói felé nyit. „Az életút-interjúk s családtörténetek a történelem egy darabját adták. (...) A huszadik század „úthengere” - minden meghatározó eseménye - átment ezeken a családokon is. Az is kiderült mindezekből, hogy hányféleképpen történik is a történelem. (...) A sorsok változandóságát az életutak sokszoros töredezettsége mutatta, a generációk között és egy generáción belül is tapasztalhattuk a folyamat megtörésének, a lesüllyedés és emelkedés dinamikáját." (Losonczi, 2005:13., 16.).

\section{A szimbolikus család}

Mint láttuk, az utóbbi két évtizedben kitágult a szocializáció fogalma és értelmezési kerete, a családfelfogások új jelentésekkel gazdagodtak A megnevezésekben azonban az intergenerációs család fogalmát kivéve mindez nem nagyon tükröződött, és jóllehet sok kutatás érintett szimbolikus tartományokat, a szimbolikus világ egyik elmélet centrumába sem került. Alapvető változást John Gillis amerikai történész munkássága hozott, felfogásában a szimbolikus család az, ami a narratíváknak jelentést kölcsönöz, miközben magát a szimbolikus családot részben a narratívák [pl. családi mítoszok, (eredet)történetek stb.] teremtik meg. Gillis szerint kétféle családunk van, az egyikkel nap mint nap együtt élünk, a másik pedig az, ami éltet bennünket. (Gillis, 1996a). Előbbi a rokoni kapcsolatban álló együttélő családot fedi, a másik pedig a szimbolikus család ${ }^{18}$, amely - többek között - az identitás alakításában játszik jelentős szerepet.

A szimbolikus család mentális konstrukció: az eltávozott, az élő és a még meg sem született családtagokat is magába 
foglalja. Ezek a szereplők benépesítik az emlékezetet, átjárják gondolatainkat egyrészt a történeteken keresztül, amelyekben különböző helyzetekben és szerepekben bukkannak elő, másrészt a rítusok, a családi események, videók és családi albumok stb. által reprezentált és közvetített konstruált családképen át elvégzik a szimbolikus munkát. A szimbolikus család így nemcsak nagyobb a fizikai családnál, időben messze túlnyúlik a saját életünkön, és összeköti a generációkat, a múltat, a jelent és a jövőt.

A család, illetve az elődök által is közvetített, hely-, helyzet- és önmeghatározást alakító családkép tehát nem azonos (Gillis, 1996a). A tágabb család a távolságok és szeparáltság következtében szimbolikus családként működve olyan állandóan változó családképet közvetít, mely a megjelenített életpályákon, életmódokon, mintákon át a társadalmi környezetre, a családi és az egyéni jellegzetességekre egyaránt reflektáló bonyolult rendszert hoz létre. Ebben a családi történetekből is megújuló tudáson és a mítoszokon túl, térben és időben is kiterjesztett szocializációs funkciók valósulnak meg. A szimbolikus család ekképpen egy olyan társadalmi-földrajzi térben és időben kiterjesztett rendszer, mely kitágítja szűkös földrajzi- fizikai létünket, miközben határt és irányt szab cselekedeteinknek, választásainknak (Boreczky, 2004, 2007).

Mindez azért történhet így, mert a szimbolikus család a társadalom tér- és időstruktúráján belül saját helyet foglal el: az egymást követő generációk kijelölik azt a teret és időt, amelyben életpályák fonódnak egybe, s amelyben generációk (módosított és korrigált) családi mintái mintázatokat alkotnak. Eképpen maga a rendszer választható cselekvési alternativákat kínál, a választásban mind az elmondott, mind az elhallgatott történeteknek fontos részük van. Az elmondott történetek közvetítők, az egyes generációk tapasztalatait adják át a következő generációknak. Mi több, olyan általánosításokat is közvetítenek, amelyek a múltban történt és az aktuális események, valamint a család és a "történelem" közötti interakciók egyeztetése és generalizálása során formálódtak, és amelyek sok esetben sajátos családi logikában összegződnek. A rendszer és határai állandóan változnak, az emlékezet, a szinkronizáció, az egyes családtagok percepciói, az újszülöttek és a családba került új 
tagok egyaránt alakítják. De azért is, mert a családnak folyamatosan reflektálnia és válaszolnia kell a társadalmi-gazdasági környezet változásaira. Mégis, amíg az alkalmazkodáson keresztül a rendszer maga is változik, elég erős ahhoz, hogy ellenálljon a külső kényszereknek és átszűrje azokat.

Gillis elméletét továbbfejlesztve Boreczky (2008) a szimbolikus család működését-funkcióit többféleképpen és több szinten értelmezi. Ezek a következők:

- fontos személyek, szignifikáns mások,

- családi ünnepek, szokások, rítusok, vakációk, albumok, dokumentumok (pl. levelezések, naplók) stb.,

- mítoszok, eredettörténetek, történetek-epizódok,

- a családi rendszer egésze.

A fontos személyekkel, szignifikáns másokkal való azonosulás révén az általuk interiorizált valóságok, illetve az általuk közvetített valóságértelmezések alkotják a szimbolikus család első szintjét. A szignifikáns mások közvetítésével nagyon sokféle valóságnak leszünk részesei, és egyes élethelyzetekben pl. nagyobb döntések előtt a tágabb rokonsági minták szerepe is sokkal fontosabb, mint gondolnánk. A sokszor rejtőzködő, látenciában maradó minták mozgósíthatnak és mozgósíthatók. „Az emlékeinkben mások mintáit hordozzuk magunkban” - írja Kenneth J. Gergen a The Saturated Self c. múvében. „Ha a feltételek kedvezőek, a mintákat cselekvésbe fordítjuk. Mindegyikünk a másik (the other) lesz, annak a reprezentánsa vagy helyettesítője. Általánosabban fogalmazva, ... énjeinket növekvő mértékben mások népesítik be." (Gergen, 1991:71)

A második szint a családi együttléteké, melyek a kvalitatív családi idő ${ }^{19}$ (Gillis, 1996b) intenzitásával együtt az összetartozást tudatosítják, az összetartozás érzését erősítik. Ezekhez társulnak a családi élet dokumentumai (esküvői fényképek, videók, nyaralások, utazások, iskolai ballagás, diplomaosztás stb. során készült felvételek, albumok), melyek már egy megszerkesztett családkép egyes szakaszait rögzítik és örökítik át a következő nemzedékre, s amelyek ugyanakkor az emlékezet múködését is kondicionálva ismételten szoros mentális és érzelmi kötelékbe vonják a család tagjait. 
A harmadik, igen kiterjedt szint a történetek szintje. A generációk közötti kommunikációban megjelenő emlékezeti idő és tér általában 3-4 nemzedéknyi, a történetek tér és idő szerkezetében, fordulópontjain, de a legegyszerúbb epizódokban is sajátos értékek közvetítődnek. Minden család számos történetet őriz, a családi mítoszok „hősöktől” és feketebárányoktól népesek, de vannak eredet-, helytállás- és hűségtörténetek, sikertörténetek, karriertörténetek, alkoholistatörténetek, öngyilkostörténetek stb., melyek a fontos személyeken keresztül megélt valóságokkal együtt egymásba is szövődve sajátos családi valósággá és értékvilággá állnak össze. ${ }^{20} \mathrm{Ez}$ utóbbi az összetartozás-tudat mellett, illetve azon keresztül az elvárásokat, és a tűréshatárokat jelzi a felnövekvő generáció számára. A történetek tehát egyfelől kanalizálnak, másfelől határkijelölő funkciójuk van.

A családi narratívá(k)ban nyíltan, gyakran azonban látensen - vagy rejtetten -sokrétegü és sokszínű valóság akkumulálódik. A múlt-jelen-jövő együttesében szerkesztett, újra- és újramondott történetek belsővé tétele révén a legfiatalabb generációkban öntudatlanul is kialakul a történelem és a személyes lét alapdimenzióihoz ( $p l$. folytonosság-változás, szabadság-determináció, hagyományőrzés-hagyományteremtés, autonómia-függőségi helyzet-kiszolgáltatottság, reflektivitásreflektálatlanság) való általánosabb viszony. A család ugyanis, akár törekszik rá, akár nem, még a legegyszerübb epizódok felidézésével is átadja saját, a mindennapok és a történelem eseményeire, folyamataira reflektáló, azokból általánosított logikáját.

A negyedik szint a tágabb család és a rokonság által reprezentált, életpályákkal-elágazásokkal szabdalt - történetileg és szinkronitásában egyaránt létező - családi rendszer egésze, melynek hatását bár számos empirikus adat bizonyítja (szakma- és foglalkozásválasztások ismétlődése, megszakadt pályák több generációval később történő folytatódása akár a nem vérszerinti családi ágon is, a költözések és a párválasztások mintázata stb.) a mélylélektan fogalmi rendszerében nagyon is jól, az eddigi kutatások alapján a bonyolult közvetítések miatt szociologikusan csak részben és még mindig csak hipotetikusan értelmezhető. 
A szimbolikus család tehát egy többrétegű közvetitő rendszer, melynek egyik legfontosabb funkciója az adaptáció elősegítése. (A család mint intézmény nem egyszerű tükörfelület, átszűri és saját logikájába illeszti a történeti-társadalmi változásokat, miközben maga is folyamatosan alakul és alkalmazkodik a szintén állandóan átalakulásban lévő társadalmi környezethez ${ }^{21}$, miközben, hogy mint család fennmaradjon, számos értéket, szokást, nyelvi formát, történetet stb. hagyományoz. A kapcsolat a napi események, a megélt valóság és a generalizált családi világ közt több-, a külső világ és a család között pedig kétirányú. A rendszerben ugyanakkor a család napi élete, a családtagok élményei és a szimbolikus tartomány egymásra rétegződnek.)

A család adaptivitását legerőteljesebben a szimbolikus családrendszer kiterjedése és flexibilitása befolyásolja. A két tényező összefügg egymással. A tágasabb rendszer nagyobb valószínűséggel több követésre és választásra alkalmas mintát integrál, ez a családi egységek és az egyének adaptivitását növeli. A kisebb kiterjedésű család gyakran rugalmatlan és merev, abban az értelemben, hogy nem rendelkezik a megújuláshoz szükséges elégséges erőforrással.

\section{Családfák és családnarratívák a pedagógiai gyakorlatban}

A pedagógia gyakorlatban az előzőkben vázlatosan ismertetett családelméleti háttér a legalább háromgenerációs családfák felvétele és elemzése, illetve a családnarrativák révén hasznosítható. ${ }^{22}$

\section{A családfák}

A többgenerációs adatokat tartalmazó családfáról sok minden leolvasható. A pedagógus a családszerkezetre és a gyerekszám alakulására vonatkozó adatokon, a házasságokon, a lakhelyeken, a foglalkozások és iskolázottság alakulásán, valamint a nemi szerepeken keresztül például képet alkothat a családi stratégiákról. Arról, hogy a családon belül áthagyomá- 
nyozottan milyen módon történik a társadalmi hely, a társadalmi státus megteremtése, illetve megőrzése, és hogy ebben milyen szerepminták örökítődnek. Arról, hogy a családi rendszerben hol vannak fordulatok, hogy mennyire rugalmas vagy rugalmatlan, miként képes vagy képtelen az alkalmazkodáshoz szükséges új boldogulási lehetőségek integrálására, illetve miIyen források állnak rendelkezésére, milyen mintákat tud mozgósítani az új helyzetekhez való alkalmazkodáshoz.

Az elmúlt évtizedek nagyon sok családban drámai fordulatot hoztak. A társadalmi változások következtében minden családnak újra kellett definiálnia a saját helyét, ami gyakran identitásvesztéssel, de legalábbis számos konfliktussal járt. Az ipari körzetek át- és leépülése például számos korábban intézményesült életstratégiát érvénytelenített, többek között a tradicionális és a falusi háttérrel rendelkező városi ipari munkásokét, és azokét a falusi családokét, amelyek tagjai korábban a helyi tsz-ben, illetve tsz-üzemben dolgoztak vagy a közeli város valamelyik ipari létesítményébe ingáztak, miközben a nagyobb család közösen a háztáji földet művelte, kertészkedett és állatokat tartott. Utóbbiak lányaikat eladónak, fodrásznak, esetleg tanárnak szánták, fiaik szakmát tanultak.

A hetvenes-nyolcvanas években értékké, a boldogulás és az érvényesülés személyes útjává, egyben identitásképző elemmé váló, a nagytársadalmi legitimáció által is erősített városi és falusi munkáslét mára elenyészett. A munkanélküliség, az alkalmi munkák, az el- vagy a falura való (vissza)költözés, esetleg a falusi önellátásra való visszaállás nehéz kérdéseket vet fel. Milyen választásokat hív életre a nyilvánvaló kényszerhelyzet? Lehetséges, hogy nagyszülői generációk - egy időre elfelejtett, de a szülők által még megélt és kisgyerekkorból ismerős vidéki szegényeinek a hangja szól vissza? Az a szegénységben fogant vágy és elképzelés, hogy ha más nem is, legalább ennivaló legyen. Elég ennyi a gyerekek jövőjéhez? És mi lesz azoknak a gyerekeivel, akik az egykori panelvilág és a gyárak szűkös, de élhetőnek megélt valóságából a kényszerű dologtalanságba kerültek? Mi lesz azokkal, akik a társadalmi tér növelésének hagyományos módját, a nagycsaládot, a tágabb családból pedig az egyre kevésbé élhető, mert egyre kevésbé releváns munkáshagyományt kapják örökül, hisz a többgene- 
rációs családi rendszer nem igen kínál számunkra több mintát és azon keresztül több választási lehetőséget? Mi lesz azokkal a gyerekekkel, akiknek valamelyik szülője külföldön dolgozik ugyan, de a kényszer szülte migrációból a negatív élményeket, a kiszolgáltatottságot és a megalázottságot hagyományozza gyerekeire? Mi lesz azokkal a gyerekekkel, akik tágabb családja zsákutcába került? Képes-e a pedagógus segíteni, hogy a gyerekek életpályája jobban alakuljon, mint szüleiké, nagyszüleiké, és ha igen, hogyan?

Ezek azok a kérdések, amikkel a pedagógusok is szembesülnének, ha mintegy mikroszkopikusan betekintenének a családi rendszerbe és annak történeti dinamikájába. És ezek azok, melyek fel sem merülnek a családi rendszer ismerete nélkül. Ha azonban a mai iskolás gyerekek támogatásához mégis a család történetének alapvonala lenne a kiindulópont, a pedagógiai stratégiát annak tudatában kellene kidolgozni, hogy a család zárt vagy nyitott rendszert alkot. A tanárok tevékenysége arra irányulna, hogy a családi pályák ismeretében és azokra épülve segítenének megfogalmazni a gyerekek számára kínálkozó lehetőségeket, illetve segítenének a zárványozódó vagy zárványozódott rendszerek felnyitásában, a lehetséges életpályák újragondolásában. Ahhoz, hogy az egyes családok története, a családi rendszerek múködése, a bennük rejlő tartalékokkal és korlátokkal együtt világossá váljon, a többgenerációs rendszerek struktúráját, a bennük zajló szerveződéseket és a változások irányát is figyelembe véve újra kell értelmezni a hátrányos helyzetet is. Talán ez lehetne az út a többgenerációs determinációk leküzdése felé. Talán így át lehetne írni a funkcionalitásukat vesztett stratégiákat, és megszabadítani a legfiatalabb generációkat az átörökített mozgásképtelenségtől.

\section{A családi narrativák}

Míg a családfák a család életének tényeit rögzítik, a történetek többek közt a szereplőkhöz és eseményekhez kötődő érzelmeket, a rájuk rakodó viszonyulásokat, nézeteket, értékeket, az események kapcsolatát értelmező általánosításokat tartalmazzák, a mítoszok pedig inkább a család identitásáról, eredetéről, vágyairól stb. árulkodnak. A történetek „abban is 
segítségünkre lehetnek, hogy feltárjuk, miként segítik vagy gátolják egymás mobilitását férfiak és nők, szülők és gyerekek, ... hogy megismerjük a fennmaradt stratégiákat, az elmulasztott lehetőségeket, az álmokat és a csalódásokat, azt, amin keresztül az egyén szakmai érvényesülése/ pályája megvalósul" (Thompson 1997:35). Ez utóbbi mondat közvetlen pedagógiai vonatkozású üzenet. De a tanárok számára valamennyi forrás kimeríthetetlen, mert a családi és családtörténeteken ${ }^{23}$ keresztül közvetített valóságok az elmesélt történelem átszemélyesített részletei egyfelől támpontokat nyújtanak az alkalmazkodás megélt perspektíváinak (vagy éppen jövőtlenségének), másfelől a családi világ egészének rekonstruálásához.

A családi mítoszok, narratívák, illetve a megkonstruált családtörténet mind egyéni, mind osztályszinten felhasználhatók. A fontos személyek mintául szolgálhatnak, erőt adhatnak, a történetek pedig erősíthetik a tanulók identitását és motivációját, orientálhatják az iskola- és a pályaválasztást, illetve a tanár számára érthetővé tesznek számos olyan tanulói reakciót, melyet korábban túlegyszerűsített vagy esetleg félreértelmezett. Közösségi szinten az iskola érvényesítési lehetőséget, nyilvánosságot biztosíthat a különböző kultúrákban gyökerező szociális és individuális világok számára. Lehetőséget teremthet arra, hogy megszerkesztett világán belül a különböző társadalmi és etnikai csoportok szerint is más-más családokban, más-más történetek közt felnövők egymás világát megismerjék, megértsék, és tovább folytassák. Ismerősebben fogalmazva alkalmat teremthet az „iskolai tudás” és a tanulók „otthonról hozott", a múlttól ugyancsak elválaszthatatlan előzetes tudása közötti összhang megteremtésére.

\section{Jegyzetek}

1 A nukleáris család szülőkből és gyerekeikből álló család.

2 A néprajz a családhoz számítja pl. a családdal együtt élő nagyszülőket, egyéb rokonokat vagy a nem együtt élő, de szoros kapcsolatot fenntartó családtagokat is.

3 A háztartás fogalma a közös gazdálkodáshoz, közös életvitelhez, a szükségletek közös kielégítéséhez kötődik.

4 A családok és háztartások formáinak/típusainak leírására na- 
gyon sokfajta osztályozási rendszer létezik. Beszélhetünk egy-, két- és többgenerációs családokról, egyszerű és összetett (több családmagot tartalmazó) háztartásokról (a családmag legtöbb esetben a nukleáris családdal azonos fogalmat takar). A statisztika a házaspár (élettárs), a házaspár (élettárs) gyerekkel és az egy szülő gyerekkel kategóriákat használja. Peter Laslett (1972) széles körűen alkalmazott háztartás-tipológiája a következő: 1. nukleáris családi háztartások, 2. kiterjesztett családi háztartások (ezekben a nukleáris családon kívül más rokon is él, leggyakrabban az egyik nagyszülő vagy a szülők még nem házas testvére), 3. több családmagból álló háztartások, 4. olyan háztartások, melynek egyetlen tagjai közül senki sem tartozik ugyanahhoz a családmaghoz, 5. egyszemélyes háztartások.

5 A családváltozások sosem egyirányúak, de az összefoglalóan modernizációnak tekintett folyamatok átalakították a gazdaság, a társadalom szerkezetét, a településszerkezetet stb. A nukleáris család térnyerése és a többgenerációs nagycsaládok visszaszorulásának tendenciái részben innen erednek.

6 Példaként álljon itt néhány adat: 1949-ben a szülőkön és gyerekeiken kívül a háztartások 17\%-ban élt más hozzátartozó vagy „idegen” , ugyanez 1990-ben 9,2 \% volt. A több családmagból (azaz több nukleáris családból) álló háztartások aránya 1949-től 1990-ig 7\%-ról 2,6\%-ra csökkent, az egyszemélyes háztartásoké viszont 10\%-ról 24,3\%-ra nőtt (Tomka, 2000:125).

7 A kritika egyrészt a család atomizált voltára, másrészt az individualizációs törekvések és a családi hagyományok-kötelékek közti feszültségre irányult. Ez utóbbi valamivel később egy újfajta, egymással folyamatos interakcióban lévő személyek által megjelenített családképben fogalmazódott meg (Burgess, 1926). A kritikákkal egyidejúleg láthatóvá váltak a különbségek pl. a vidéki és városi vagy a többségi és kisebbségi családok között is, ez megbontotta az addigi polgárcsalád (az angol nyelvű szakirodalomban többnyire középosztálybeli család)-munkáscsalád kettősségét, és a családkép differenciálódásához vezetett.

8 Parsons elméletét nagyon sok irányból érték kritikák, a társadalmi intézmények, struktúrák kényszerítő ereje sokak számára túlzottan deterministának is tetszett. Ennek ellenére munkássága a családról való gondolkodás nagyon fontos állomása, mert az átörökített vagy előírt státussal az egyén által megszerzett státust állítja szembe.

9 A felsorolás nem teljes. Nagyon sokféle kategória létezik, Murdock (1949) a szexualitással, a reprodukcióval, a gazdasággal és a neveléssel összefüggő funkciókat különböztet meg, Andorka (2006) 
a termelési, fogyasztási, szocializációs és a felnőttek pszichés védelmét biztosító (vö. Parsons) funkciókat említi. Bodonyi, Busi és Vizely (2006) több szerző alapján a következő családfunkciókkal dolgozik: biológiai funkciók, gazdasági funkció, az érzelmeket kielégítő családi funkció, a társadalmi státus meghatározása, a betegek ellátása és az öregekről való gondoskodás, a kulturális igény felkeltése-a szabadidő irányítása, a családtagok életének irányítása és ellenőrzése, a család mint támogató rendszer

10 A mai migrációs folyamatok alapján hozzáfúzhetjük azt is, hogy a szocializációs folyamat során az egyénnek interkulturális-, de a kultúraváltáshoz szükséges készségeket is el kell sajátítania.

11 Igen összetett hatásrendszert jelenít meg Bronfenbrenner (1986) ökológiai elmélete. Ebben az egyén szocializációjára a következő, egymással is kapcsolatban álló öt rendszer gyakorol hatást:

- a mikrorendszer szintje (microsystem - az egyént közvetlenül befolyásoló környezet és az ebben realizálódó családi, szomszédsági, baráti stb. személyes kapcsolatok);

- a mezorendszer (mesosystem - az egyén mikrorendszerei pl. a család és az iskola közötti kapcsolat);

- az exorendszer (exosytem - az egyént közvetve befolyásoló külső környezet pl. szülők munkahelye, kapcsolathálója, tömegkommunikáció stb.);

- a makrorendszer (macrosystem - az adott társadalomra-kultúrára jellemző domináns nézetek, értékek stb.) és

- a kronorendszer (chronosystem - az időbeli változások szintje).

12 A nukleáris család szinonimájaként is használják, jóllehet jelentésében a házastársi kapcsolat hangsúlyosabb. Egy vagy két generáció alkotja, jellemzően a szülők és gyerekeik.

13 Louis Henry és Pierre Goubert francia történészek történeti-demográfiai módszerét alkalmazva, illetve kiterjesztve Laslett és a Cambridge Groupnak nevezett csoport kutatói történeti dokumentumokból rekonstruálták a család- és háztartásszerkezetet.

14 Egy kései kilencvenes évekbeli hozzászólásában Laslett a következőképpen összegzi a modernitás és a nukleáris családokról szóló vitákkal kapcsolatos véleményét: „Minden mai, a világ bármely táján létező gyakorlat vagy intézmény modern, tűnjön bármennyire régiesnek vagy elavultnak, mert a történész számára a modernség a dolgok időbeliségét jelenti. Így az 1993-as indiai vagy kínai házasságok, amelyeket a szülők hoztak össze, éppoly „modernek”, mint az amerikai vagy svéd szerelmi házasságok..." (Laslett, 1995:5). Ugyanebben az írásában a nukleáris családdal és az ipari társadalommal kapcsolatban Laslett azt 
állítja, hogy a keleti családszerveződések nemhogy nem ellentétesek az ipari társadalmakkal, hanem még jobban is alkalmazkodnak hozzájuk, mint a nyugat-európaiak (Laslett, 1995).

15 Általában olyan többgenerációs család, amelyben az egyik gyerek (gyakran a legidősebb fiú) házassága és gyerekei születése után is együtt marad a szüleivel.

16 Bengston egy korábbi írására hivatkozva Mabry, Giarusso és Bengston a nagyszülők növekvő szerepét hangsúlyozzák. Így például a nagyszülőknek nagyon erős kompenzációs szerepük lehet a válások esetén, csökkenthetik a felbomlott család okozta kockázatokat (Mabry, Giarusso és Bengston, 2004).

17 Egy 2001 és 2004 között folyó családkutatás eredményei szerint az 573 megkérdezett közül 172 azt válaszolta, hogy a nagyszülők a szúk családhoz tartoznak, akár együtt élnek velük, akár nem (Boreczky és mtsai, 2007).

18 A szimbolikus családértelmezések a családi intézmény felbomlását, a család válságát hangsúlyozó nézetekkel szemben jelentek meg. Teljesen új kontextust teremtenek, amikor az új családfunkciókat részint a hagyományos vallási-települési-foglalkozási közösségek felbomlási folyamatába illesztve, mintegy azok szimbolikus munkájának átvételére alapozva fogalmazzák meg.

19 A Making Time for Family c. (1996b) tanulmányában Gillis ír arról, hogy, bár pl. a 19. századi, ma hagyományosnak nevezett család több időt töltött együtt egy helyen, az idő nagy részében mindenki dolgozott, vagyis az idő és az együttlét elsődlegesen nem a családtagok közötti kapcsolat, szeretet, törődés stb. kifejezésének keretét alkotta. Ennél fogva az időt önmagában nem lehet automatikusan a családi összetartozás, egymás iránti figyelem stb. mérőszámának tekinteni. Mi több, Gillis szerint a mai család, bár ritkábban és kevesebbet találkozik, ezeket az alkalmakat arra használja, hogy erősítse a kapcsolatokat, az összetartozás élményét ( $p l$. beszélgetések, vasárnapi ebédek, ünnepek, utazások stb.). Ezt nevezi Gillis kvalitatív időnek.

20 Természetesen vannak olyan (szegény vagy szétszóródott stb. családok) esetek, amikor a családban nincs összefüggő történet. (A szakirodalomból ismert, hogy a családtörténet elterjedése a polgárosodáshoz, a családon belüli polgárosodási folyamatokhoz kötődik). De epizódok mindenütt vannak, és ha nem is alkotnak teljes valóságértelmezést, önmagukban is jelentés értékúek.

21 A családi változások nem jentik, hogy a családon belül minden folyamatosan változik, mert számos dolog változatlanul vagy kis módosítással örökítődik.

22 Joggal felvethető, hogy a mai körülmények között miként van 
egy pedagógusnak családfák készítésére és családi interjúkra ideje és lehetősége. Már csak azért is, mert a családlátogatás az utóbbi években egyáltalán nem általános gyakorlat. Az is felhozható, hogy a pedagógusok nem rendelkeznek az ilyenfajta tevékenységhez szükséges szaktudással. Mindennek ellenére, ha komolyan gondolkodunk azon, hogy miként lehetne változtatni sokak esélytelenségén, komolyan fontolóra kellene vennünk egy, az Egyesült Államokban már bevált módszernek a bevezetését, a tanárok felkészítését, antropológusok és pszichológusok bevonását, illetve a családlátogatások visszaállítását.

23 A családi történetek bármilyen kisebb történetek-epizódok lehetnek, a családtörténet viszont általában a család generalizált logikája alapján egybefüzött többgenerációs történet.

\section{Irodalomjegyzék}

Anderson, M. (1971): Family Structure in Nineteenth Century Lancashire. Cambridge University Press, Cambridge.

Anderson, M. (1995): Approaches to the history of the western family 1500-1914. Cambridge University Press, Cambridge. Andorka Rudolf és mtsai (2006): Bevezetés a szociológiába. Osiris Kiadó, Budapest.

Andorka Rudolf és Faragó Tamás (1984): Az iparosodás előtti (XVIII-XIX. századi) család és háztartásszerkezet vizsgálata. Agrártörténeti Szemle, 3-4, 402-437.

Andorka Rudolf (2001): Gyermek, család, történelem. Andorka Rudolf Társadalomtudományi Társaság-Századvég Kiadó, Budapest.

Aries, Ph. (1987): Gyermek, család, halál. Gondolat, Budapest. Armstrong, W. A. (1972): A note on the household structure of mid-nineteenth century York in comparative perspective. In: Laslett, P. és Wall, R. (szerk.) Household and family in the past time: Comparative Studies in the Size and the Structure of the Domestic Group over the Last Three Centuries in England, France, Serbia, Japan and Colonial North America with Further Materials from Western Europe. Cambridge Univerity Press, Cambridge, 205-214.

Badinter, E. (1999): A szerető anya. Az anyai érzés története a 17-20. században. Csokonai Kiadó, Debrecen. 
Berger, B. és Berger, P. L. (1983): The war over the family: Capturing the middle ground. Garden City, Anchor Press, Doubleday.

Berger, P. L. és Luckmann, T. (1998): A valóság társadalmi felépítése: tudásszociológiai értekezés. Jószöveg Műhely Kiadó, Budapest.

Bertaux, D. és Thomson, P. et al.: Pathways to Social Class. A Qualitative Approach to Social Mobility. Clarendon Press, Oxford.

Blum-Kulka, S. (1997): Dinner Talk. Cultural Patterns od Sociability and Socialization in Family Discourse. Lawrence Erlbaum Associates, Mahway, N. J.

Bodonyi Edit, Busi Etelka és Vizely Ágnes (2006): A család funkciói. In: Hegedűs Judit (szerk.) Család, gyermek, társadalom. A gyakorlati pedagógiai néhány alapkérdése. 5. kötet. Bölcsész Konzorcium-ELTE PPK Neveléstudományi Intézet, Budapest, 14-18.

Boreczky, Ágnes (2004): A szimbolikus család. Gondolat Kiadó, Budapest.

Boreczky Ágnes és mtsai (2007): Családok távolból és félközelből. Gondolat Kiadó, Budapest.

Boreczky Ágnes (2008): Családtörténet és társadalmi-földrajzi mozgás: a szimbolikus család szerepe. In: Sallai Éva (szerk.) Társadalmi egyenlötlenségek, a nem hagyományos családmodell, a szülöi viselkedés és a gyermekek fejlődésének összefüggései. Educatio Társadalmi Szolgáltató Nonprofit Kft. Budapest, 107-115.

Bronfenbrenner, U. (1986): Ecology of the family as a context for human development: Research perspectives. Developmental Psychology, 22, 72-742.

Burgess, E. W. (1926): The family as a Unity of Interacting Personalities. Family, 7. 3-9.

Cressy, D. (1986): Kinship and kin interaction in early modern England. Past and Present, 113, 38-69.

Crow, G. és Maclean, C. (2004): Families and Local Communities. In: Scott, J., Treas, J. és Richards, M. (szerk.) The Blackwell Companion to the Sociology of Families. Blackwell Publishing, Oxford, 69-84.

Duke, M. (2005): The Integrative Model of Family Reflexivity: An emergent interdisciplinary MARIAL perspective on 
family function and its application to the study of family adjustment. Emory Center for Myth and Ritual in American Life, Working Paper No. 41

Edgar, R. (2004): Globalization and Western Bias in Family Sociology. In: Scott, J., Treas, J., és Richards, M. (szerk.) The Blackwell Companion to the Sociology of Families. Blackwell Publishing, Oxford, 3-16.

Fiese, H. B. (2006): Family Routines and Rituals. Yale University Press, New Haven-London.

Fivush, R., Bohanek, J. G., Robertson, R. és Duke, M. (2004):

Family Narratives and the Development of Children's Emotional Well-Being. In: Fiese, H. B. és Pratt, M. W. (szerk.) Family Stories and the Life-Course. Lawrence Erlbaum Associates, Mahway, 55-77.

Fivush, R., Bohanek, J. G. és Duke, M. (2005): The intergenerational self: Subjective perspective and family history. Emory Center for Myth and Ritual in American Life, Working Paper No. 44.

Gergen, K. J. (1991): The Saturated Self. Dilemmas of identity in contemporary life. Basic Books, New York.

Giddens, A. (2008): Szociológia. Osiris Kiadó, Budapest.

Gillis, J. R. (1985): For Better for Worse: British Marriages, 1600 to the present. Oxford University Press, New York.

Gillis, J. R. (1996a): A World of Their Own Making: Myth, Ritual, and the Quest for Family Values. Basic Books, New York.

Gillis, J. R. (1996b): Making Time for Family: The Invention of Family Time(s) and the Reinvention of Family History. Journal of Family History, Vol. 21, 4-21.

Goode, W. J. (1971): World Revolution and Family patterns. Journal of Marriage and the Family, Nov. 1971 624-635.

Goode, J. (1972): The evolution of the family. In: Laslett, P. és Wall, R. (szerk.) Household and family in the past time: Comparative Studies in the Size and the Structure of the Domestic Group over the Last Three Centuries in England, France, Serbia, Japan and Colonial North America with Further Materials from Western Europe. Cambridge University Press, Cambridge, 104-124.

Greeven, P. J. (1972): The average size of families and households in the Province of Massachusetts in 1764, and in 
the United States in 1790: an overview. In: Laslett, P. és Wall, R. (szerk.) Household and family in the past time: Comparative Studies in the Size and the Structure of the Domestic Group over the Last Three Centuries in England, France, Serbia, Japan and Colonial North America with Further Materials from Western Europe. Cambridge University Press, Cambridge, 545-561.

Hall, E. T. (1983): The Dance of Life. Doubleday, New York.

Hajnal, J. (1965): European Marriage Pattems in Perspective, In: Glass, D. V. és Eversley, D. E. C. (szerk.) Population in History, Edward Arnold Publ., London, 101-143.

Hajnal, J. (1983): Two kinds of Preindustrial Household formation systems. In: Wall, R. (szerk.) Family forms in historic Europe. Cambridge University Press, Cambridge, 65-104. Hammel, E. A. (1972): The zadruga as process. In: Laslett, P. és Wall, R. (szerk.) Household and family in the past time: Comparative Studies in the Size and the Structure of the Domestic Group over the Last Three Centuries in England, France, Serbia, Japan and Colonial North America with Further Materials from Western Europe. Cambridge University Press, Cambridge, 335-375.

Hareven, T. K. (1978, szerk.): Transitions. The Family and the Life Course in Historical Perspective. Academic Press, New York-London.

Hareven, T. K. (2000): Families, History and Social Change. Life-Course and Cross-Cultural Perspectives. Boulder Co, Westview Press.

H. Sas Judit (2003): Közelmúlt: rendszerváltások, családtörténetek. Új Mandátum Könyvkiadó, Budapest.

Kagitcibasi, C. (2003): A család és a család változása. In: Nguyen Luu Lan Anh és Fülöp Márta (szerk.) Kultúra és pszichológia. Osiris Kiadó, Budapest, 311-335.

Laslett, P. (1965): The World We Have Lost. Methuen, London. Laslett, P. (1972): Mean household size in England since the sixteenth century. In: Laslett, P. és Wall, R. (szerk.) Household and family in the past time: Comparative Studies in the Size and the Structure of the Domestic Group over the Last Three Centuries in England, France, Serbia, Japan and Colonial North America with Further Materials from 
Western Europe. Cambridge University Press, Cambridge, 126-158.

Laslett, P. (1983): Family and household as work group and kin group: areas of traditional Europe compared. In Wall, R., Robin, J. és Laslett, P. (szerk.) Family Forms in Historic Europe. Cambridge University Press, Cambridge, New York, 513-563.

Laslett, P. (1995): The Family in the Industrializing East and the Industrial West. In: Chin-Chun Yi (szerk.) Family Formation and Dissolution: Perspectives form East and West. Academia Sinica, Taipei, 1-33.

Losonczi Ágnes (2005): Sorsba fordult történelem. Holnap Kiadó, Budapest.

Levi, G. (1990): Family and Kin - a few thoughts. Journal of Family History, 15, 567-578.

Litwak, E. (1965): Extended Kin Relations in an Industrial Society. In: Shanas, E. és Streib, G. T. (szerk.) Social Structure and the Family: Generational Relations. Prentice-Hall, Englewood Cliffs, NJ.

Mabry, J. B., Giarrusso, R. és Bengston, V. L. (2004): Generations, the Life Course and Family Change. In: Scott, J., Treas, J. és Richards, M. (szerk.) The Blackwell Companion to the Sociology of Families. Blakwell Publishing, Oxford, 87-109.

Mead, G. H. (1973): A pszichikum, az én és a társadalom. Gondolat Kiadó, Budapest.

Meleg Csilla (2006): Az iskola időarcai. Dialóg Campus, Budapest-Pécs.

Mitterauer, M. (1992): A History of Youth. Blackwell Publishing, Oxford.

Murdock, P. G. (1949): Social Structure. Macmillan Company, New York.

Nakane, Ch. (1972): An interpretation of the size and structure of the household in Japan over three centuries. In: Laslett, P. és Wall, R. (szerk.) Househoand family in the past time: Comparative Studies in the Size and the Structure of the Domestic Group over the Last Three Centuries in England, France, Serbia, Japan and Colonial North America with Further Materials from Western Europe. Cambridge University Press, Cambridge, 517-543. 
Parsons, T. (1955): Family Structure and the Socialization of the Child. In: Parsons, T. és Bales, R., F. (szerk.) Family, Socialization and Interaction Process. The Free Press, Glencoe, Ilinois, 35-133.

Parsons, T. és Bales, R. F. (1955): Family, Socialization and Interaction Process. The Free Press, Glencoe, Ilinois.

Péter Katalin (1996, szerk.): A gyermek a koraújkori Magyarországon., MTA Történettudoményi Intézet, Budapest.

Pollock, L. (1983): Forgotten Children. Parent-Child Relations from 1500 to 1900. Cambridge University Press, London, New York.

Pratt, M. W. és Fiese, B. H. (2004): Family stories and the life course: Across time and generations. Erlbaum Associates, Mahwah, NJ.

Pukánszky Béla (2001): A gyermekor története. Műszaki Könyvkiadó, Budapest.

Ruggles, S. (1987): Prolonged Connections: the rise of the extended family in nineteenth century England and America. The University of Wisconsin Press, Wisconsin

Ruggles, S. (1994): The transformation of American family structure. American Historical Review, 99. p, 103-128.

Shahar, Sh. (1990): Childhood in the Middle Ages. Routledge, London, New York.

Scott, J., Treas, J. és Richards, M. (2004, szerk.): The Blackwell Companion to the Sociology of Families. Blackwell Publishing, Oxford.

Somlai Péter (2002): Húsz év. Új Mandátum Kiadó Budapest.

Szabolcs Éva (1995): Fejezetek a gyermekkép történeti alakulásából. ELTE BTK, Pro Educatione Gentis Hungariae Alapítvány, Budapest.

Thomson, P. (1997): Women, Men and Transgenerational FamiIy Influences in Social Mobility. In: Bertaux, D., Thomson, P. és mtsai: Pathways to Social Class. A Qualitative Approach to Social Mobility. Clarendon Press, Oxford, 32-62.

Tomka Béla (2000): Családfejlődés a 20. századi Magyarországon és Nyugat-Európában: konvergencia vagy divergencia? Osiris Kiadó, Budapest.

Wall, R. (1972): Mean household size in England from printed sources. In Laslett, P. és Wall, R. (szerk.) Household and 
family in the past time: Comparative Studies in the Size and the Structure of the Domestic Group over the Last Three Centuries in England, France, Serbia, Japan and Colonial North America with Further Materials from Western Europe. Cambridge University Press, Cambridge, 159-205. 



\section{PUSZTAI GABRIELLA}

\section{Tőkeelméletek az oktatáskutatásban}

\section{Alapfogalmak}

Tóke. A nevelésszociológiai kutatások a közgazdaságtudománytól adaptálták a tőke fogalmát. A közgazdasági gondolkodásnak évszázadok óta egyik központi fogalma a tőke, melyet eredendően profittermelésre és önmaga reprodukálására alkalmas, a gazdaságba befektethető tárgyi (föld, munkaeszközök stb.) vagy pénzbeli eszközként határoztak meg, de a közgazdaságtudomány klasszikusai is hamar arra a következtetésre jutottak, hogy maga az ember (szellemi javaival, képzettségével, munkaerejével, hasznosítható információival) is felfogható tőkeként. Például az emberi tőke kifejezés első említése az angol William Pettytől származik, aki 1676-ban a háborús anyagi veszteségek mellett az emberveszteség értékét is igyekezett meghatározni (Lengyel és Szántó, 1998), majd a 18-19. század számos neves tudósa követte példáját a fogalomhasználatban, s mára számos (első hallásra talán meglepőnek tetsző) tőkefajta koncepciójáról olvashatunk. A tőkefogalom ilyen kiterjesztésével kapcsolatban sokan ellenérzésüket fogalmazzák meg, sokszor erkölcsi alapon (pl. az embert - a rabszolgaság megszúnése óta - nem lehet vagyonná vagy tókévé degradálni, hiszen az csak az emberek javáért létezhet) (Schultz, 1963). Mások ideológiai, politikai terheltsége miatt kritizálják használatát, mivel a győztes kapitalista világrend kulcsfogalmát, egyben központi értékét emeli piedesztálra, s azt a látszatot kelti, hogy tulajdonképpen mindenki tőketulajdonos (Sík, 2012). A kritikák harmadik vonulata a közgazdasági (anyagi) tőkefogalommal szemben ennek pontatlanságát, mérésre való alkalmatlanságát emeli ki, lényegében felesleges gazdasági metaforának tartja (Bruce, 
1993), s a „közgazdaságtan imperializmusaként” kárhoztatják a közgazdasági szemlélet és fogalomkészlet átvitelét más tudományok területeire (Cserne, 2000). Mindezen - sok tekintetben elgondolkoztató - észrevétel mellett leszögezhetjük, hogy a 20. század második fele óta a tőkeelméletek megkerülhetetlenek a nevelésszociológia számára is (Pusztai, 2009). A tőkefogalom népszerúségéhez hozzájárult, hogy az ezen a néven összefoglalt tényezők összehasonlíthatókká válnak a következő szempontok alapján: átalakítóképesség (a javakat milyen más javakká alakítják), konvertálhatóság (milyen könnyen konvertálhatók más tőkefajtákká), állandóság (működésük során megtartják-e eredeti állapotukat), elveszíthetőség, elidegeníthetőség, rugalmasság és helyettesíthetőség (az általuk előállítható javak sokfélék, illetve más tőkékkel kombinálhatók), romlékonyság (a használat során milyen könnyen mennek tönkre), illetve megbízhatóság (mennyire biztos a megfelelő múködésük) (Robinson, Schmid és Siles, 2002).

Emberi tőke (human capital). Az emberben megtestesülő, részben veleszületett, de nagyobbrészt szerzett fizikai és szellemi készségek, képességek, ismeretek, tulajdonságok összessége, melyek befektethető erőforrásként jelennek meg számára, ezáltal növelik termelőképességét, „piaci értékét”. Ezen keresztül hat egyéni életének minőségére, anyagi és szociális helyzetének változására, de társadalmi hasznot is termel. Eredetileg a korai és a klasszikus közgazdaságtan képviselői által használt fogalom, tudományos paradigmává az 1960-as évektől vált, elsősorban Schultz, Minzer és Becker munkássága révén. Nem egyenlő a tudástőkével, amely azonban fontos része az emberi tőkének, emiatt különösen kiemelt az emberi tőke elmélet az oktatásökológiai kutatások számára. Közvetlen gazdasági megtérülésén kívül externális haszna révén is jelentős társadalmi hatást gyakorol (lásd spillover hatás). Az emberi tőke fogalma megjelenik Coleman terminológiájában is, nála azonban lényegében Bourdieu kulturális tőke (lásd ott) fogalmával egyenértékú.

Képzelőerő-tőke: Becker által használt fogalom, mely szerint a jelenben hozott döntések jelentős részben attól függnek, 
hogyan képzeli el az egyén annak jövőbeli hatásait. A szerző szerint az alacsonyabban iskolázott egyének e tőkefajta hiányában alulértékelik a jövőbe való befektetetésük várható hosszú távú hasznosságát, ezért értékpreferenciáikban inkább jelenközpontúak, míg a magasabb iskolázottság együtt jár a nagyobb jövőtudatossággal. (Ld. kulturális tőke.) Vizsgálják ebből a szempontból pl. az egészségtudatosság és az iskolázottság összefüggését vagy a tanulásba, képzésbe való befektetés megítélését a jövőtervek kialakításában.

Tovagyürüző hatás (spillover effect). Eredetileg közgazdaságtudományi kifejezés, amely azt a folyamatot jelöli, melynek során az egyik gazdasági szektorban végrehajtott beruházás vagy integráció (általában pozitiv) tovagyűrűző hatást gyakorol a gazdaság más szektoraira is. A fogalom kiemelten szerepel az emberi tőke elméletben, ahol az emberi tőke beruházás externális hatásaként tárgyalják. Az egyén szintjén pl. az iskolázottság növekedésével párhuzamosan az egészségtudatosabb életmódra, a szociálisan és kulturálisan gazdagabb életre való törekvésként figyelhető meg. Az egyéni hasznon túl még jelentősebb oszthatatlan társadalmi haszna (pl. regionális hatásként a magasabban képzett dolgozók tömeges migrációja megváltoztathatja egy település arculatát vagy egy társadalomban az iskolázottság jelentős növekedését összefüggésbe hozhatjuk a munkanélküliség és a bűnözés csökkenésével, a demokratikus értékrend, a nyitottabb gondolkodás, az általános tájékozottság növekedésével. E hatásra hivatkozva, az oktatás kvázi közjószág jellegét hangsúlyozva érvel számos szakember az oktatás állami finanszírozása mellett.

Gazdasági tőke. A közgazdaság-tudomány egyik alapfogalma, az alapvető termelési tényezők egyikeként a gazdaságba befektetethető javak gyújtőfogalma, mely által a termelési folyamatban értéktöbblet hozható létre, vagyis haszon, nyereség keletkezhet. A gazdasági tőkével való ellátottság különösen a modern társadalmakban az egyik legfontosabb státusmutató. A társadalomtudományi tőkeelméletekben Bourdieu a „közvetlenül pénzzé konvertálható" tőkét nevezi így, s a társadalmi struktúra reprodukciójának leghatékonyabb eszközét látja 
benne, domináns tőkeformának tekinti, mert mindenfajta tőke elosztása elsősorban a gazdasági tőkével való egyenlőtlen rendelkezésben gyökerezik. Coleman a gazdasági helyett fizikai vagy tárgyi tőkéröl ír, s nézete szerint leginkább a társadalmi tőke váltható át humán tőkévé.

Habitus. A reprodukciós elmélet a társadalmi egyenlőtlenségek átörökítésének legalapvetőbb dimenziójának tartja. A habitus a társadalmi struktúrában való elhelyezkedés nyomán megélt tapasztalatok és mindennapi gyakorlat (a családi nevelési gyakorlat) során bevésődött előzetes beállítódások, elvárások, értékek összessége, melyek az egyén objektív körülményeivel összhangban vannak, s biztosítják, hogy közvetlen megfelelés legyen a saját jövőre vonatkozó anticipáció és a valószínúleg bekövetkező pályafutása között. Ennek segítségével megvalósul az objektív helyzethez való alkalmazkodás, az esélyek objektív egyértelműségként való érzékelése, ami például a továbbtanulási aspirációkat (terveket) is determinálja.

Kapcsolati tőke. Részben a társadalmi tőke (lásd ott) szinonimájaként, részben alternatívájaként használt fogalom. Sok kutató aluldefiniáltnak vagy túl általánosnak tartja a társadalmi tőkét, illetve közgazdaságilag nem mérhetőnek, ezért annak egy lényegi vonását, az egyének vagy csoportok közti kapcsolatot kiemelve, a kapcsolati vagy a hálózati tőke kifejezést preferálja, főleg a gazdaságszociológiában és a közgazdaságtudományban. E megközelítések elsősorban az instrumentális és haszonszerzés céljából létesített kapcsolati erőforrásokra fókuszálnak, melyek a kapcsolathálón kívüliek kizsákmányolására teszik alkalmassá birtokosukat, miközben a számításmentességen és szimpátián alapuló kapcsolatokra koncentráló szerzők inkább ragaszkodnak a társadalmi tőke elnevezéshez. Bourdieu e fogalmat lekötelezettségi tőkének is nevezi (lásd szimbolikus tőke).

Kulturális tőke. Bourdieu az emberi tőke (lásd ott) elméletének továbbgondolásával, illetve azzal vitatkozva alkotta meg a fogalmat. Az egyén kulturális tőkéjének szerinte három öszszetevője van: az inkorporált kulturális tőke az egyén belső- 
vé tett, tartós készségek formájában elsajátított személyiségrésze, habitusa (nyelvhasználat, ízlés, viselkedés, ismeretek stb.), melyet részben a családi, részben az iskolai szocializációban hosszú idő alatt sajátít el. Az objektivált kulturális tőke az általa birtokolt kulturális javak összessége (könyvek, műalkotások, hangszerek, számítástechnikai eszközök stb.), de a kultúra ezen anyagi hordózóit az egyén csak inkorporált tőkéje szerint képes hasznosítani. Az intézményesült kulturális tőke a kulturális kompetenciák tárgyiasult bizonyítéka (bizonyítványok, diplomák, nyelvvizsgák, tudományos fokozatok, címek stb.), mely „tulajdonosának tartós és jogilag garantált konvencionális értéket kölcsönöz". A kulturális tőkével való rendelkezés szerinte a társadalmi egyenlőtlenségek által determinált, illetve azok egyik fenntartója, továbbörökítője.

Szimbolikus tőke. Bourdieu által leírt tőkefajta, melyet tekintélytőkének illetve lekötelezettségi tőkének is nevez. Birtoklása társadalmi státust biztosít az egyén számára, meghatározza társadalmi pozícióját, kulturális elismertségét, általános presztízsét, hitelképességét. Alapja a gazdasági tőke és az objektív hatalmi pozíció, illetve annak mások által „legitimként észlelt és elismert formája", mely segít a hatalmi viszonyok fenntartásában. A hagyományos társadalmakban szimbolikus tőkét biztosít pl. a cím, a család rangja, az életkor és tapasztalat, a nemzedékek során a családban felhalmozódott tekintély, becsület. A modern társadalmakban az egyén által mozgósítható kapcsolatok hálójának kiterjedtségétől, valamint annak a tőkének a nagyságától függ, melyet a vele kapcsolatban állók birtokolnak, így a társadalmi egyenlőtlenségek fenntartásának egyik eszköze.

Kapcsolathálózati elemzés (networkanalízis). A 20. század első felében a szociálpszichológiából elinduló vizsgálati módszer, mely eredetileg a mikroközösségek társas viszonyainak feltérképezését célozta, alkalmazása mára a nagyobb közösségek társadalmi kapcsolataira, illetve magára a társadalmi struktúrára is kiterjedt. Használható a társadalmi tőke strukturális dimenziójának (a hálózatok szerkezete, a kapcsolatok mennyiségi vonásai, a kapcsolathálók közötti határvonalak), illetve az 
egyes szereplők kapcsolatrendszerének feltárására, az egyén helyzetének meghatározására a networkön belül. A kapcsolatháló szereplőit csomópontoknak nevezik (lásd pl. híd-szerep), a határvonalak az a priori networkök esetében (pl. egy iskolai osztály) valóságosak, de lehetnek a kutató által aggregáltak is, vizsgálható egy speciális kapcsolattípus (pl. barátság) vagy egy egyén, illetve csoport összes kapcsolattípusa egyaránt.

Erős és gyenge kötések. A társadalmi tőke elmélethez kapcsolódó, Granovetter által bevezetett fogalompár, melyben a kapcsolatok erejét az összesen beléjük fektetett idő, érzelem és intimitás szerint osztályozza és értékeli. Erős kötés a szoros és többfunkciós (multiplex) családi vagy baráti kapcsolat, gyenge kötés a lazább, egyfunkciójú (uniplex) ismerősi. Vitakérdés a két kapcsolattípus hasznának megítélése: Coleman az erős kötéseknek tulajdonít nagyobb szerepet (lásd closure), mások (pl. Granovetter vagy Lin) szerint a kizárólagos erős kötések korlátozott mennyiségük és hatótávolságuk miatt elszigeteltséget, ezáltal hátrányos helyzetet teremtenek az egyén számára, míg a gyenge kötések nagy társadalmi távolságok áthidalására képesek, miközben ritkább sűrűségű kapcsolathálót képeznek. Az ún. híd-szerepben levő egyének a társadalmat hálózatok végtelen hálózatává teszik, összekötik a hálózatokat és áramoltatják a friss információkat (lásd összetartó és összekötő [bonding és bridging] kapcsolatok).

Összetartó és összekötő kapcsolatok. Putnam kapcsolathálózati vizsgálataiban összetartó (bonding) és összekötő (bridging) kapcsolatokat különböztet meg. Előbbi a kisebb közösségek kohézióját biztosítja, utóbbi a hálózatok közötti átfogó kötések kialakítására vonatkozik. A kettő nem áll ellentétben egymással, a bonding kötések létesítésének képessége előrejelezheti a bridging kötések kialakítására vonatkozó hajlandóságot is. Burt modellje szerint a hálózatok interakciókban realizálódnak, bennük erőforrások (köztük információk) áramlanak. Ezek jobban terjednek a csoportokon belül (bonding kapcsolatokban), mint a csoportok között, de kulcsszereplővé azok a híd-szereplők válnak, akik közvetítőként képesek a hálózatok határain kialakuló strukturális hézagok áthidalására (bridging 
kapcsolatok létesítésére). Vitakérdés, hogy a híd-szereplő csak egyéni hasznot könyvelhet-e el, vagy spillover hatásként (lásd ott) a bizalomsugár és a kooperációs normák minden csoporttagra kiterjednek-e.

Closure. Zárt, erős kötésekre alapozott kapcsolathálózati forma. Coleman szerint a társas kapcsolatok közül társadalmitőke-termelő képességüket tekintve az inkább mikroszintű, zárt körre korlátozódó kontaktusok a legelőnyösebbek, melyekben a kapcsolatháló minden egyes tagja ismeri az összes többit, a közös normákra alapozottság véd a deviáns viselkedés ellen, a kölcsönös bizalom pedig többletteljesítményre, a közjóért való lemondásra és jótékonyságra ösztönzi a tagokat. A legkomplexebb struktúra az intergenerációs closure, amelyben az egymással kapcsolatban levő szülők, tanárok és a gyerekek családon kívüli kapcsolataikkal zárt struktúrát alkotnak. Kutatók különösen gyermek- és ifjúkorban tartják fontosnak az ilyen típusú iskolai kapcsolatrendszerbe tartozást, amely hatékony normaátadást tesz lehetővé, valamint spillover hatásával a más típusú tőkeformákkal kevésbé ellátott tagok számára is előnyöket biztosít.

Társadalmi tőke. A fogalom 20. század eleji nevelésszociológiai felbukkanása után az 1980-as években Bourdieu és Coleman is konceptualizálta, de az utóbbi munkássága nyomán vált a társadalomtudományi elmélet alapjává, s az ezredforduló óta számos szakszociológia alkalmazza. A társadalmi tőke a személyközi viszonyokban ölt testet, Bourdieu megfogalmazásában a "társadalmi kötelezettségekből vagy kapcsolatokból fakad”, de ő kisebb jelentőséget tulajdonít neki, mint a gazdasági és a kulturális tőkének, ellentétben Colemannel, aki szerint e tőkefajta váltható át leginkább humán tőkévé, s képes az egyéb tőkehiányok pótlására. Az élő kapcsolatok termelik újjá, alapját a közös normák, az egymás iránti bizalom, a kölcsönös csere képezi. Tartalmi dimenziójában a közös tudásrendszer és elkötelezettség dominál, strukturális dimenziójában a kapcsolatok mennyiségi és minőségi vonásaival jellemezhető. A társadalmi tőke elméletben számos kérdés még nyitott: a fogalom pontos definíciója (lásd kapcsolati tőke), a különböző közösség- 
és kapcsolattípusok előnyei és hátrányai (lásd closure, erős és gyenge kötések, bonding és bridging kapcsolatok), az elmélet alkalmazhatósága, a társadalmi tőke hatékonysága, funkciója.

Vallási tőke. A társadalmi tőke klasszikusai (Bourdieu, Coleman, Putnam) kiemelten vizsgálták a vallásosság és a vallási közösségek tőketermelő szerepét, $s$ a vallási tőkét a társadalmi tőke (lásd ott) egy speciális fajtájának tekintették. lannacone felosztása szerint a vallási humán tőke ismeretekből (vallási oktatási tőke), a tanításokhoz és rituálékhoz való viszonyból (vallási kulturális tőke), valamint a többi egyháztaghoz való kapcsolatból (vallási társadalmi tőke) tevődik össze. Finke lényegében az első kettőt a vallás személyes vonatkozásaként spirituális tőkének nevezi, a harmadikat társadalmi tőkének. A vallásos gyakorlat e felfogásban részben termelőtevékenység (idő-, pénz- és munkabefektetéssel), részben vallási javak fogyasztása (hit, szeretet, elégedettség, bizalom stb.). Minél nagyobb mennyiségben felhalmozott vallási tőkével rendelkezik egy egyén, annál inkább tartózkodik attól megválni (más felekezetre térni, migrálni).

\section{Elméletek, alapvető kutatások}

\section{Az emberi tőke elmélete}

Mint a fentiekben látható, az ember tőkeként való felfogása több mint háromszáz éves gondolat (Kiker 1966), s értékének meghatározásakor hamar fény derült az iskolázottsággal, képzettséggel való szoros összefüggésére. Leggyakrabban Adam Smith alapvető művét, $A$ nemzetek gazdagságát idézik ennek megvilágítására: „Költséges új gépet azért állítunk üzembe, mert azt várjuk, hogy különleges munkájával, amit teljes elavulásáig végez, nemcsak megtéríti nekünk a ráfordított tőkét, hanem ezen felül még meghozza legalábbis a szokásos profitot. Ilyen költséges géphez hasonlithatjuk az olyan embert, aki sok munkát és időt áldoz, hogy kitanuljon valami különleges készséget és szaktudást igénylő mesterséget. Azt várjuk, hogy a munka, amit megtanult, az egyszerü munkabérén felül 
megtéríti a tanulásra fordított összes költséget, és ezen felül meghozza egy, a költségösszeggel egyenlő nagyságú tökének legalábbis a szokásos profitját. Teszi pedig mindezt megfelelő időn belül, tekintettel az emberi élet nagyon is bizonytalan tartamára, szemben a gépek sokkal biztosabban meghatározható élettartamával. Ezen az elven alapszik a szakképzett munka és a tanulatlan munka bére közötti különbség." (Smith, 1992:110).

Az 1960-as években három, egymással párhuzamosan publikáló, a chicagói iskolához kötődő amerikai szerző, Theodore Schultz (1963), Jacob Mincer (1970) és Gary Becker (1964) múvei nyomán alakult tudományos elméletté az emberi tőke gondolata. Újszerúsége abban ragadható meg, hogy számos - addig az ember fogyasztási kiadásaként értelmezett tevékenységet - racionális döntés során kalkulált beruházásként értelmezett, sőt megpróbálta az ezeket összegszerűen meghatározni ${ }^{1}$.

E beruházások leginkább az oktatás, szakképzés, kutatás, egészségügy és a migráció, munkaerő-vándorlás területén figyelhetők meg, melyek egy része valóban csupán kiadásként értelmezhető, de amennyiben az ember termelőképességét $\mathrm{s}$ ezáltal piaci értékét növelik, hozamot termelnek az egyén számára, vagyis valójában az emberi tőkébe való befektetésnek minősülnek. Ezeknek a befektetéseknek a közvetlen pénzbeli haszna különböző végzettségűek életkereseti görbéinek öszszehasonlításával szemléltethető (az alacsonyabb végzettségú ember hamarabb áll munkába, így hamarabb keletkezik jövedelme, ám ennek mértéke elmarad a később munkába álló, de magasabb jövedelmet realizáló egyénétől, akinek kereseti görbéje meredekebben emelkedik). Ha egyéni racionális döntésnek tekintjük a továbbtanulási, képzettségnövelési szándékokat, akkor ezek csak addig a pontig „érik meg”, amíg a beruházás diszkontált (aktuális értéken elszámolt) hozama meghaladja a diszkontált költségeket. Ennek a pontnak a meghatározása azonban igen bizonytalan, függ az egyén élettartamától, értelmi, tanulási és perspektívaalkotó képességeitől (képzelőerő-tőkéjétől), illetve rajta kívül álló tényezőktől, mint pl. a (jelen és jövőbeli) gazdasági helyzettől' ${ }^{2}$. Az erre vonatkozó számítások megbízhatatlanságához hozzájárul, hogy a nem 
közvetlenül pénzben kifejezhető tényezőkkel is be kellene vonni a haszonmaximalizálást célzó mérlegelésbe: Ilyenek a jobb munkakörülmények, a nagyobb munkapiaci rugalmasság, a technikai változásokhoz való nagyobb alkalmazkodóképesség, az életkilátások javulása, a kulturális nívó növekedése, magasabb presztízs, előnyösebb társadalmi kapcsolatok elérése, vagyis a kulturális és társadalmi tőkenövekmények (Harbison és Myers, 1966).

Ezek az externális (külsődleges) hatások nemcsak az egyén (illetve családtagjaik) szintjén ragadhatók meg, jelentkeznek egy vállalatnál, amely továbbképzésekkel igyekszik növelni dolgozóinak emberi tőkéjét (így saját értékét), egy településen, régióban, amely megpróbál ebből a szempontból jövedelmezőbb populációt magához vonzani, de a társadalom egésze számára is előnyösek. Spillover hatásként hozzájárulnak egy ország gazdasági és társadalmi fejlődéséhez, mely visszahat az egyénre, annak erőforrásait gazdagítja vagy szegényíti. Így a népesség iskolázottsága és egészségügyi állapota kvázi közjószágnak (de legalábbis vegyes jószágnak) tekinthető (Varga, 1998). Az oktatás szintjeinek és mértékének állami támogatása a közösségi és az egyéni megtérülés nehéz elhatárolhatósága miatt válik vitakérdéssé. A nevelésszociológia az oktatási költség-haszon számítások összegszerű meghatározásával (valamint ezek elméleti és módszertani problémáival ${ }^{3}$ ) nem foglalkozik, hanem elsősorban a tanulmányi karriert támogató sokszínű erőforrás-együttes tényezőinek azonosítására törekszik, és a hatásuk - minél teljesebb nevelési-oktatási kontextus figyelembevételével történő - összehasonlítására vonatkozóan végez elemzéseket.

Az emberi tőke elméletet elsősorban azért bírálják, mert arra az előfeltevésre épít, hogy az egyének oktatási magatartása kizárólag gazdasági logikát követ, s a kulturális tényezőket nem veszi figyelembe. Így például az elmélet egyes alkalmazói abba a tévedésbe esnek, hogy a tanulók, a szülők, az intézmények magatartása teljes egészében önérdekkövető individuumok racionális haszonmaximalizálási törekvéseként interpretálható. Így egydimenziós és alulszocializált emberképpel dolgoznak, s a befektetésről és a megtérülésről alkotott felfogás értékpreferenciákon nyugvó természete vagy kö- 
zösségi dimenziói lényegében értelmezhetetlenek maradnak számukra. A nevelésszociológiai kutatások számolnak azzal, hogy az individuumok racionalitása korlátozott, a lehetőségekről alkotott vélekedések formálódásakor az egyénnek jobbára nem áll rendelkezésére a megfelelő mennyiségű és minőségi információ, ezért akarva, nem akarva beérik a számukra elég jónak tûnő alternatíva választásával, azaz a korlátozott racionalitással (Elster, 1997). Emellett a nevelésszociológiai szemléletmód előtt nem marad rejtve, hogy a beruházáskor használt információkat, a hasznosságról alkotott előfeltevéseket a kultúra, a társadalmi kontextusba való beágyazottság alapvetően befolyásolja. A tanulmányi beruházásokkal kapcsolatos racionális választás tételének elfogadása mellett Raymond Boudon hangsúlyozza, hogy az insrumentális (önérdekkövető, célelvű) racionalitás mellett a döntési mechanizmusokban része van az ún. axiológiai racionalitásnak is, amelyben a befektetéshez és a megtérüléshez kapcsolódó kalkulációk a cselekvő által ezekhez rendelt értékelő ítélet szerint módosulnak (Boudon 2003).

\section{A kulturális tőke és a reprodukciós elmélet}

A kulturális tőke elméletként emlegetett teória szerint az individuumok messze nem racionális cselekvők, hanem társadalmi osztályuk képviselői, akik osztályhelyzetükben gyökerező mechanikus reakciókat adnak az oktatásuk során. Az ebből a tételból kiinduló, konfliktuselméleti paradigmában mozgó nevelésszociológiai koncepciók a társadalmat elsősorban az egyes társadalmi érdekcsoportok egymás elleni szakadatlan küzdelmének terepeként értelmezik, melyben a tét a javak, a társadalmi pozíciók megszerzése, megtartása. A marxista elmélet és fogalomkészlet hatása alatt alkotók szerint ez a harc leginkább az egymással szemben álló osztályok (osztályfrakciók, rétegek) között folyik, melyek között az erőforrások (tőkék) egyenlőtlenül oszlanak meg. Az előnyösebb gazdasági helyzetű csoportok képesek kumulálni (egymásra halmozni) a többi tőkefajtát is, s így reprodukálni hatalmi helyzetüket. A társadalmi pozíció megtartásának és megerősítésének ezt a törvényszerüségét metaforikusan Máté-effektusként ${ }^{4}$ emlegetik, a tudományos elnevezése pedig reprodukciós elmélet. 
Az elmélet legnagyobb hatású képviselője a francia Pierre Bourdieu, aki az 1970-80-as években alkotta meg átfogó elméletét, melyben három fő tőkefajtaként a gazdasági, kulturális és a társadalmi tőkét nevezte meg.

A 20. századi Karl Marx által is használt munkaérték-elméletet idéző tőke meghatározása szerint „,a tőke vagy anyagi formában, vagy elsajátított, inkorporált formában felhalmozott munka", a profit termelésének, illetve önmaga reprodukciójának eszköze, melynek birtoklásával „lehetővé válik a társadalmi energia tárgyiasult vagy élő munka formájában való elsajátítása is" (Bourdieu 1978:155). A társadalmi struktúrát alapvetően vertikális hierarchiában (alá-fölérendeltség szerint) vizsgálja, s azokat a tényezőket azonosítja, amelyek az egyén helyét kijelölik a társadalom szerkezetében. Bourdieu Max Weber tanítványaként azt vallja, hogy a strukturáló erők több dimenzióban múködnek. A legfontosabb ezek közül a közgazdasági tőkefogalommal megegyező, „közvetlenül pénzzé konvertálható" (Bourdieu 1978:158) gazdasági tőke helymeghatározó szerepe. A fóként a családban áthagyományozódó, de a 20. században egyre inkább az oktatási intézményrendszer piacán elérhető végzettségekkel meghatározható kulturális tőke a második fő struktúraalkotó tényező. A harmadik pedig a „társadalmi kötelezettségekből vagy kapcsolatokból fakadó társadalmi tőke" egyenlőtlen elosztása révén áll elő (Bourdieu 1978:158). A modern világ domináns tőkeformájának a gazdasági tőkét tartja, de a tőkék átválthatósága (konverziója) és összegződése eredményezi végső soron azokat az egyértelmű és tartós viszonyokat, melyekben az érdekkövető, versengő egyének osztályuk reprezentánsaként viselkednek (egyéni habitusuk az osztályhabitusuk által determinált), hogy tőkéiket átörökíthessék utódaikra.

A gazdasági tőke kulturális tőkére való tömeges konvertálása a modernizáció kihívására adott válasz. Az iskolai siker a családi kulturális tőkebefektetés függvénye, akár műveltség, elegáns nyelvhasználat vagy kifinomult magatartás (inkorporált kulturális tőke), akár birtokolt kulturális javak (objektivált kulturális tőke), akár különböző szintű iskolai végzettség (intézményesült kulturális tőke) formájában áll rendelkezésre. Az objektivált kuturális tőke anyagi természeténél fogva átruház- 
ható, azonban inkorporált kulturális tőke szükséges a rendeltetésszerü használatához. Az előzetesen felhalmozott kulturális tőke mértéke oly módon is meghatározza a tanulmányi beruházási stratégiákat, hogy a társadalmi osztályoknak speciális habitustípusaik alakulnak ki, amelyek többek között a jövővel és a munkavégzéssel, iskolával kapcsolatos tartós beállítódásokból állnak.

Az elmélet különös figyelmet fordít a tőkefajták közötti átváltásra, mivel tőkével rendelkezők stratégiái arra vonatkoznak, hogy megőrizzék és növeljék tőkéiket. A különböző tőkefajták közötti együttjárás lényeges megnyilvánulása, hogy a magas gazdasági és kulturális tőkeellátottság hasonló helyzetűekkel való kapcsolattartást von maga után, s ez a kapcsolati tőke a szívességek és lekötelezettségek révén tud a gazdasági tőke gyarapításához hozzájárulni. Arra a kérdésre, hogy az alapvetően gazdasági tőkét központba helyező elméletben mi az oktatás szerepe, a tőkekonverzióval kapcsolatos stratégiák időbeli változása ad választ, hiszen a modernizáció egyik központi mozzanataként értelmezi az oktatás tömegessé válását is. A Max Weber által is elemzett, szakértelemre alapozott modern gazdasági szervezetekben a diplomákkal szavatolt kulturális tőke világos pozíciókijelölő tényezővé vált, s ez megváltoztatta a felső középosztály reprodukciós stratégiáját. Ennek eredményeképpen a vagyonok tulajdonosai javaik egy részét oktatási beruházásokra kezdték átváltani. A gazdasági tőkével rendelkező családok sarjai aztán jó nevű intézményekben, keresett szakokon szerzett végzettségük, társadalmi összeköttetéseik, az ezek presztízsére épülő szimbolikus tőkéjük révén jól fizetett állásokra és gyorsabb karrierre esélyesek, így történik a kulturális tőke rekonverziója (visszaváltása) gazdasági tőkévé.

Az iskolarendszer az előnyös helyzetű társadalmi osztályok, osztályfrakciók hatékony eszköze arra a célra, hogy legitimálják a kulturális tőke újratermelődésének folyamatát, hiszen a kulturálistőke-ellátottság egyenlőtlen társadalmi eloszlása nemcsak megmagyarázza a tanulmányi siker osztálykülönbségeit, hanem a tanulók iskolai karrierjével kapcsolatban valószínűnek érzékelt kilátások elfogadására ösztönzi az egyént és a családot. A jobban kommunikáló, a magaskultúra világában könnyed, s a helyzethez illő otthonossággal viselkedő, több 
háttérismerettel és ismeretszerzési eszközzel, rutinnal rendelkező, az iskolarendszer és az intézmények világában jobban eligazodni képes egyének behozhatatlan iskolai előnyére figyelmeztet az elmélet. Az iskolarendszer ugyanis ebben a modellben egyértelműen a társadalmi egyenlőtlenségek elfogadtatását és besulykolását szolgáló intézmény. Az iskola a tőkékben gazdag osztályok tőkebefektetési stratégiájának eszköze. A tanárok feladata az egyes csoportok számára nagyon távoli, ám társadalmilag és az oktatási intézmények világában domináns kultúraelsajátítás erőltetése. Az iskolarendszerben zajló kommunikációt hatalmi viszonyok hatják át, a feltörekvő és az alsóbb osztályok képviselőinek a kiváló minősítésekre való esélye törvényszerúen csekély.

\section{A társadalmi tőke mint hátránykompenzáló tényező}

A társadalmi tőke ma használatos kifejezése egy 20. század eleji amerikai oktatásszervező s egyben oktatáskutató (Hanifan 1916) tollából született, aki az iskola társadalmát körülvevő az egy helyen élő emberek és családok közötti barátságokon, kölcsönös szimpátián alapuló kapcsolattartással önállóan létező tényezőként számolt. Jelentőségét abban látta, hogy a közösséghez való tartozás javítja az iskola hatékonyságát, s ennek révén megoldhatja az individualizálódás, az atomizálódás, valamint a világháború okozta általános bizalomvesztés és a bevándorlók integrációjának problémáit ${ }^{5}$.

A társadalmi tőke önálló elmélete a korábbi szórványos előfordulásokat követően az 1980-as években jelent meg James Coleman (Coleman és Hoffer 1987; Coleman 1988, 1990), amerikai nevelésszociológus munkássága nyomán. Ezzel párhuzamosan alkotta meg Pierre Bourdieu a maga kapcsolati tőke fogalmát, mely köré nem szervezett koherens elméletet. Mivel még a szakirodalom is gyakran összekeveri a két koncepciót, az alábbiakban összehasonlítjuk őket.

Coleman az emberi tőke elmélet, a racionális cselekvéselmélet és a csereelmélet szintézisére törekedett, szemben a marxi és weberi előzményeket követő Bourdieu-vel. Míg Bourdieu az osztályhelyzete kényszereinek mechanikusan engedelmeskedő egyénnel számol, Coleman elméletének alapja 
az egyéni szinten jelentkező szükségletek kielégítésére irányuló szándékos cselekvés. Coleman nem a társadalmi osztályokból, osztályfrakciókból álló társadalomszerkezetet tartja a meghatározónak, mint Bourdieu, hanem felhívja a figyelmet egy másik struktúrára, amelyet az egyének kapcsolatai alkotnak, s a társadalmat keresztülmetszve átszövik a társadalmi osztályok, osztályfrakciók határait. Coleman elmélete a racionális, célkitǔző cselekvés alapelvének elfogadása mellett a konkrét társadalmi környezet kontextusának szerepét és módosító hatását is hangsúlyozza, hiszen az egyéni szükségletkielégítésre irányuló folyamatok a környezetben realizálódnak. Ezzel nemcsak az egyéni cselekvésre, hanem a társadalmi struktúra formálódására is magyarázatot kívánt adni. Az iskolai folyamatok (a tanulók iskolaválasztása, illetve teljesítménye), véleménye szerint nemcsak a vertikális társadalmi struktúrában elfoglalt helyzet és az individuális választások eredménye, hanem a konkrét társadalmi kapcsolatok egyéni döntésekre gyakorolt hatása. Ő is három tőkefajtát különít el: a fizikai (materiális, gazdasági), az emberi (lásd fentebb) és a társadalmi tőkét, s ez utóbbinak meghatározó jelentőséget tulajdonít. Ezt a társadalmi csere rendszerében egymással együttműködő cselekvők kapcsolatainak tulajdonságaként értelmezi (Coleman, 1990). A viszonyrendszert nem konfliktuselméleti megközelítésben tárgyalja, hanem kölcsönös hatásgyakorlásként, a társadalmi tőke nála nem a kizsákmányolás eszköze.

Coleman Bourdieu-nél kevesebbet foglalkozik a kapcsolatháló kiépülésével. Miközben Bourdieu nagy hangsúlyt helyez az ún. intézményesítési rítusok ${ }^{6}$ leírására, Coleman az élő, múködő kapcsolatok jelentőségét hangsúlyozza. A koncepció szerint a találkozások egy minimális mennyisége szükséges ahhoz, hogy éljen a bizalom, múködjenek a csoportnormák, lehetőség legyen a szankciókra, vagyis a társadalmi tőke kifejthesse hatását. A kapcsolattartásnak mind a formális, szervezeti keretek között létrejövő, mind az informális változatait effektívnek tartja. Leginkább a funkcionális közösségek, a család, a lakókörnyezeti közösségek, az önkéntes csoportok és a vallási közösségek felelnek meg az általa leírtaknak, s empirikus kutatásaiban is azokat az oktatási intézményeket tapasztalta hatékonyabbaknak, amelyek képesek magukba integrálni vagy lét- 
rehozni a tanulók szerves közösségeit. Bourdieu-nél az egyén osztályhelyzete által determinált érdekkövető, Colemannél a kapcsolati struktúra hatására formálódik a célkövető cselekvése. Bourdieu-nél a tudatos befektetési stratégiák eredménye a kapcsolati erőforrásokhoz való hozzáférés, Colemannél a társas hálózatokat nem kifejezetten abból a célból hozzák létre, hogy társadalmi tőkét termeljenek velük, ezek más funkciót betöltő kapcsolathálók (pl. karitatív szervezet, vallási közösség), s mintegy melléktermékként jelenik meg bennük a társadalmi tőke, ezért a befektetés-megtérülés viszonyok ún. externalitások. Igaz, hogy a kapcsolatok nem járnak közvetlen haszonnal, viszont az erről való lemondás a jövőben több profitot eredményez, amikor a kapcsolattartásra fordított, látszólag elfecsérelt erőforrások megtérülnek. Bourdieu koncepciójában a hálózatokon belül is hierarchikus egyenlőtlenségek ${ }^{7}$ uralkodnak, Coleman viszont azt hangsúlyozza, hogy a struktúrához tartozók számára elérhetővé válik mindaz, ami individuálisan nem szerezhető meg. Ha az egyén kilép a struktúrából, kárt okozhat a többieknek (mivel ezzel megszakítja az információ, a bizalom és a társadalmi kontroll láncolatát), de egyszersmind önmagának is. Coleman elismeri a csoporton belüli helyzetkülönbségeket, de kiemeli a zárt kapcsolathálóban jól múködő, az önző tevékenységet szankcionáló, az önérdeket háttérbe szorító normákat. Nála elsősorban a kapcsolati struktúra jellemzői (stabilitása, zártsága, sűrűsége, normákhoz való viszonya) képeznek értéket, s a leggazdagabb tőkeforrásnak a kapcsolatháló kohézióját tartja, amikor egy egyén barátai egymással is szoros kapcsolatban vannak (closure).

\section{Nemzetközi trendek, hazai interpretációk}

A kutatói múhelyekből kikerülő tőkefogalmak közül néhány az oktatás nemzetközi és hazai szakértői múhelyeiben is nagy sikert aratott. Az emberi tőke fogalma a hatvanas-hetvenes években népszerúvé vált az angolszász szakirodalomban, majd az ezredforduló óta többé-kevésbé leegyszerúsített koncepcióját előszeretettel használják az oktatást a gazdasági fejlődés tükrében vizsgáló nemzetközi szervezetek (pl. az OECD) arra 
hivatkozva, hogy a globalizált tudásgazdaságban a képzett munkaerő értéke dinamikusan nő, s az egyes országok, kormányok teljesítőképességét összehasonlítják abból a szempontból, hogy hol mit értek el az emberi tóke növelésében (Keeley, 2007). A nemzetközi összehasonlítások hosszú ideig az oktatási rendszer egy-egy szintjét elérők vagy elvégzők arányával operacionalizálták az emberi tőke fogalmát, majd a közoktatásból kilépők képességmérésének és nemzetközi összehasonlításának gyakorlata kielégítette a kritikusokat (Jones és Porrafke 2014), s elindították azt a konceptualizációs folyamatot, amely jelenleg a felsőoktatásban megszerzett végzettség mögött álló képességek összetételét és mérési lehetőségeit elemzi (Heuser, 1997, Tremblay és mtsai, 2012). Hazai viszonylatban az emberi tőkekoncepció makrogazdasági statisztikákon túlmutató, nevelésszociológiai szempontból értékes, újszerű alkalmazása a generációk közötti emberitőke-áramlás gondolatának felvetése, a gyermekvállalás és gyermeknevelés, sőt a gyermeket vállaló nők tanulásának emberitőke-beruházásként való értelmezése (Gál, 2003; Engler 2007). Az iskolai sikeresség magyarázatát kereső empirikus elemzésében Bukodi (1999) finomította a fogalmat, mikor megkülönböztette a foglalkozási pozícióhoz kötődő képzettségként és a formális iskolai végzettségi szintként operacionalizált emberi tőkét, valamint a tőke felhalmozásának nemenként eltérő vonásait.

A kulturális tőke elmélet teljes elméleti gazdagságában még ma sem széles körben ismert az angolszász oktatásszociológiai irodalomban, azonban a kulturális tőke társadalmi státust átörökítő hatásáról bonyolult statisztikai elemzések születtek (DiMaggio, 1982; De Graaf, 1986, 1989; Ganzeboom és mtsai, 1990). Magyarországon a kulturális tőke társadalomfilozófiai szempontból megalapozott koncepciójának recepciója Ferge Zsuzsa és munkatársai közvetítésével (Ferge és Háber, 1974) történt meg, empirikus vizsgálatai pedig arra hívták fel a figyelmet, hogy az egyenlőségelvű szocialista iskolarendszerben is tovább él az alacsony státus reprodukciója (Ferge, 1972; Gazsó, 1976; Kozma, 1981). Hazai viszonylatban Róbert Péter 1986-os munkája végezte el Bourdieu tőkekoncepciójának első alapos operacionalizálását, s a magyar oktatáskutatók immáron harmadik nemzedéke foglalkozik az iskolázás 
és a társadalmi mobilitás összefüggéseinek a reprodukciós elméleten nyugvó magyarázatmodelljeivel - számos empirikus adatelemzésen ellenőrizve a koncepció tételeit kezdetben a közoktatásban, később a felsőoktatásban vizsgálódva (Andor és Liskó, 2000; Róbert, 1986; Liskó és Fehérvári, 1998; Blaskó, 1999; Fényes és Verdes, 1999; Róbert, 2000). Az újabb hazai elemzések az elmélet mélyrétegeiből merítve az idővel kapcsolatos prediszpozíciók, valamint a szabadidős és munkavégzési habitus tanulói, hallgatói különbségeinek elemzésével mutattak rá az elmélet eddig kimerítetlen rétegeire (Meleg, 2006; Bocsi, 2013, 2015).

A társadalmi tőke elmélet főként Putnam közremúködésével szintén a nemzetközi szakértői körök érdeklődésébe került, majd erősen leegyszerűsített változata popularizálódott (Orbán és Szántó, 2005), emellett a gyakran Bourdieu kapcsolati tőkére vonatkozó gondolataival összekeverve tárgyalják, ezért fontos lépés volt visszanyúlni az elméletalkotó eredeti nevelésszociológiai koncepciójához (Pusztai, 2009). A Colemanhipotézist, mely szerint a társadalmi tőkének a társadalmi státus reprodukciós determinizmusait kompenzáló hatása van, a nemzetközi kutatók sora ellenőrizte (Carbonaro, 1998, 1999; Sampson, 1999; Corten és Dronkers, 2006). Hazai viszonylatban felekezeti középiskolások vizsgálatakor először Pusztai Gabriella erősítette meg (Pusztai, 2004), majd a szektorközi összehasonlítás nyomán azt állapította meg, hogy ez a mechanizmus iskolafenntartó szektortól függetlenül is érvényesül (Pusztai, 2009). A felsőoktatási intézmények hallgatói fejlődéshez való hozzájárulása után kutatva az elmélet felsőoktatási alkalmazására került sor a hallgatók intézményi beágyazódásának hatásával foglalkozó nemzetközi vitákhoz történő hozzászólásként (Pusztai, 2011, 2015). A colemani társadalmi tőke elmélet alkalmazásának lehetőségeit különösen a nem-tradicionális tanulói, hallgatói csoportok iskolai eredményessége (Pusztai, 2003; Bacskai, 2015) valamint az önkéntes közösségi tagságra épülő nevelési-oktatási formák hasonló hatása kapcsán kínál további lehetőségeket (Bognár, 2012; Pusztai 2012; Kovács, 2015). 


\section{Jegyzetek}

1 Leghamarabb Mincer (1958) készítette el ún. egyszerú modelljét, melyet később módosított (kiterjesztett modell), de Becker (1962) is megkísérelte egyenletbe foglalni elgondolását, s nyomukban számos közgazdász szerző.

2 Ezek miatt az emberi tőkébe való beruházás kockázata és bizonytalansága jóval nagyobb a fizikai tőkeberuházásokénál (Varga, 1998).

3 Magyarul jó összefoglalója ennek Varga, 1998.

4 A metafora egy evangéliumi kijelentésen alapul: „Akinek van, annak még adnak, hogy bőségesen legyen neki, de akinek nincs, attól még azt is elveszik, amije van." (Mt. 13.12.)

5 Mestere, Dewey az iskola közösségi nevelési funkcióját hangsúlyozta, amely áthidalhatja a társadalmi törésvonalakat. A társadalmat olyan szövetségként értelmezte, amelyben az egymással lokális kapcsolatban álló egyének az oktatási intézmények által formált közösségekben a demokráciát veszélyeztető makroszintű folyamatokkal szemben is hatni tudnak.

6 A társadalmi tőke újratermeléséhez szükséges az idő és a pénz folyamatos befektetése (pl. körutazások, vadászatok, bálok, exkluzív kulturális és sportrendezvények, klubok, előkelő lakónegyedekben lakás és elit iskolák látogatása stb.), melyek révén létrejön a "beavatottság” szubjektív érzéseken vagy jogi garanciákon alapulva. A csoport határai zártak, az új tagok belépése akár veszélyeztetheti is a csoportot.

7 Minél nagyobb a kapcsolati tókébe befektetett gazdasági tőke, annál nagyobb annak jövedelme, s így a legnagyobb "tőkebefektetők" összpontosíthatják a csoport összes társadalmi tőkéjét, a csoport képviselői, delegáltjai lehetnek. Ez azt a lehetőséget is magában hordja, hogy a reprezentációval és delegációval felruházott személyek hatalmukat akár a csoport ellen is fordíthatják, melyet Bourdieu a társadalmi tôke célelidegenedésének nevez. 


\section{Irodalomjegyzék}

Andor Mihály és Liskó Ilona (2000): Iskolaválasztás és mobilitás. Iskolakultúra, Budapest.

Bacskai Katinka (2015): Mit ér (el) a tanár, ha közép-európai? Belvedere Meridionale, Szeged.

Becker, G. S. (1962): Investment in Human Capital. A Theoretical and Empirical Analysis with Special Reference to Education. Journal of Political Economy, LXX. 9-49.

Becker, G. S. (1964): Human Capital. University of Chicago, Chicago.

Becker, G. S. (1998): Preferenciák és értékek. In: Lengyel Gy. és Szántó Z. (szerk.) Tőkefajták: a társadalmi és kulturális erőforrások szociológiája. Budapest, Aula Kiadó, Budapesti Közgazdaságtudományi Egyetem, 101-129.

Blaskó Zsuzsa (1999): Kulturális tőke és társadalmi reprodukció. Szociológiai Szemle, 1, 69-96.

Bocsi Veronika (2013): Az idő a campusokon. Belvedere Meridionale, Szeged.

Bocsi Veronika (2015): A felsőoktatás értékmetszetei. Új Mandátum Kiadó, Budapest.

Bognár Adrienn (2012): A társadalmi tőke egyes mutatóinak vizsgálata a pécsi és a debreceni egyetemisták körében. In: Dusa Á. R., Kovács K., Márkus Zs., Nyüsti Sz., Sőrés A. (szerk.) Egyetemi élethelyzetek. Debreceni Egyetemi Kiadó, Debrecen, 165-181.

Boudon, R. (2003): Beyond Rational Choice Theory. Annual Review of Sociology, 29. 1-21.

Bourdieu, P. (1978): A társadalmi egyenlőtlenségek újratermelődése. Gondolat Kiadó, Budapest.

Bourdieu, P. (1998): Gazdasági tőke, kulturális tőke, társadalmi tőke. In: Lengyel Gy. - Szántó Z.(szerk.) Tőkefajták: A társadalmi és kulturális erőforrások szociológiája. Aula Kiadó, Budapest. 155-176.

Brian, K. (2007) Human Capital: How what you know shapes your life. OECD Publishing, Párizs.

Bruce, S. (1993): Religion and rational choice. A critique of economic explanations of religious behavior. Sociology is Religion, 54, 193-205. 
Bukodi Erzsébet 1999): Osztály vagy réteg? Történeti változások, emberi tőke, karrierminták a foglalkozási osztály- és réteghelyzet vizsgálatában. Szociológiai Szemle, 2, 28-39.

Carbonaro, W. (1998): A Little Help from My Friends' Parents: Intergenerational Closure and Educational Outcomes. Sociology of Education, 71, 295-313.

Carbonaro, W. (1999): Opening the Debate on Closure and Schooling Outcomes. American Sociologocal Rewiew, 64, 682-686.

Coleman, J. S. (1990): Foundations of Social Theory. Harvard University Press, Cambridge, M.A.

Coleman, J. S. (1988): Social Capital in the Creation of the Human Capital. Amerian Journal of Sociology, 94, S95-S120.

Coleman, J. S. és Hoffer, T. (1987): Public and privat high schools. The Impact of communities. Basic Books, New York.

Corten, R. és Dronkers, J. (2006): School Achievement of Pupils from the Lower Strata in Public, Private Government-Dependent and Private, Government-Independent Schools: Across-national test of the Coleman-Hoffer thesis. Educational Research and Evaluation, 12, 2, 179-208.

Cserne Péter (2000): Gary Stanley Becker, a preferenciák és a közgazdaságtan imperializmusa. Szociológiai Szemle, 10, 1, 113-127.

De Graaf, P. M. (1989): Cultural Reproduction and Educational Stratification. In: Bakker, B. F. M., Dronkers, J. és Meijnen, G. W. (eds.) Educational Opportunities in the Welfare State. Nijmegen.

De Graaf, P. M. (1986): The Impact of Financial and Cultural Resources on Educational Attainment in the Netherlands. Sociology of Education, Vol. 59, 237-246.

DiMaggio, P. (1982): Cultural Capital and School Success. American Sociological Review, Vol. 47, 189-201.

Elster, Jon (1997): A társadalom fogaskerekei. Osiris Kiadó, Budapest.

Engler Ágnes (2011): Kisgyermekes nők a felsőoktatásban. Gondolat Kiadó, Budapest.

Fényes Hajnalka és Verdes Emese (1999): Döntés preferálással. Szociológiai Szemle, 2, 58-76. 
Ferge Zsuzsa (1972): A társadalmi struktúra és az iskolarendszer közötti néhány összefüggés Szociológia, 1, 10-35.

Ferge Zsuzsa és Háber Judit (1974, szerk.): Az iskola szociológiai problémái. Közgazdasági és Jogi Könyvkiadó, Budapest.

Gál Róbert Iván (2003, szerk.): Apák és fiúk és unokák. Osiris Kiadó, Budapest.

Ganzeboom, H. B. G., De Graaf, P. M. és Róbert, P. (1990): Cultural Reproduction Theory on Socialist Ground: Intergenerational Transmission of Inequalities in Hungary. In: Kalleberg, A. L. (ed.) Research in Social Stratification and Mobility, 9, 93-120.

Gazsó Ferenc (1976): Iskolarendszer és társadalmi mobilitás. Kossuth Kiadó, Budapest.

Hanifan, L. J. (1916): The Rural School Community Centre. Annals of the American Academy of Political and Social Science, 67. 130-138.

Harbison, F. és Myers, C. A. (1966): Elméletek az emberi erőforrás fejlődéséről. Tankönyvkiadó, Budapest.

Heuser, L. (2007): Academic Social Cohesion within Higher Education. Prospects: Quarterly Review of Comparative Education, 37. 3. 293-303.

Jones, G. és Porrafke, N. (2014): Human Capital and National Institutional Quality: Are TIMSS, PISA, and National Average IQ Robust Predictors? Center for Economic Studies, München.

Kiker, B. F. (1966): The Historical Root of the Concept os Human Capital. Journal of Political Economy, Vol. 74, No. 5, 481-499.

Kovács Klára (2015): A sportolás mint támogató faktor a felsőoktatásban. Oktatáskutatók könyvtára 2. Felsőoktatási Kutató és Fejlesztő Központ, Debrecen.

Kozma Tamás (1981): Hátrányos helyzet. Tankönyvkiadó, Budapest,

Lengyel György - Szántó Zoltán (1998q): Tökefajták: A társadalmi és kulturális erőforrások szociológiája. Aula Kiadó, Budapest

Liskó Ilona és Fehérvári Anikó (1998): Felvételi szelekció a középfokú iskolákban. Oktatáskutató Intézet, Kutatás Közben 219, Budapest. 
Meleg Csilla (2006): Az iskola időarcai. Dialóg Campus, Pécs. Mincer, J. (1958): Investment in Human Capital and Personal Income Distribution. The Journal of Political Economy, 66, 4, 281-302.

Mincer, J. (1970): Schooling, Experience, and Earnings. Columbia, New York.

Orbán Annamária és Szántó Zoltán (2005): Társadalmi tőke. Erdélyi Társadalom, 2, 55-70.

Pusztai Gabriella (2003): A társadalmi tőke szerepe a roma/ cigány diplomások iskolai pályájának alakulásában. In: Kozma T. és Pusztai G. (szerk.) Roma/cigány értelmiségiek iskolai karrierje. Acta Pedagogica Debrecina CII. 55-79.=Kapcsolatban a jövővel. Valóság, 5. 69-84.

Pusztai Gabriella (2015): Pathways to success in higher education. Peter Lang, Frankfurt am Main.

Pusztai Gabriella (2012): Hallgatói vallásosság és felsőoktatási beágyazottság. In: Földvári M. és Nagy G. D. (szerk.) Vallás a keresztény társadalom után: Tanulmányok Tomka Miklós emlékére. Belvedere Meridionale, Szeged, 229-253.

Pusztai Gabriella (2004): Iskola és közösség. Felekezeti középiskolások az ezredfordulón. Gondolat Kiadó, Budapest.

Pusztai Gabriella (2009): A társadalmi tőke és az iskola. Új Mandátum Könyvkiadó, Budapest.

Pusztai, Gabriella (2011): A láthatatlan kéztöl a baráti kezekig. Hallgatói értelmező közösségek a felsőoktatásban. Új Mandátum Könyvkiadó, Budapest.

Róbert Péter (1986): Származás és mobilitás. Társadalomtudományi Intézet, Budapest.

Robison, L. J., Schmid, A. A. és Siles, M. E. (2002): Is Social Capital Really Capital? Review of Social Economy, LX. (1), 1-21.

Sampson, R.J., Morenoff, J. D. és Felten, E. (1999): Beyond Social Capital: Spatial Dynamics of Collective Efficancy for Children. American Sociologocal Rewiew, 64, 633-661.

Schultz, Th. (1963): The Economic Value of Education. Columbia University Press, New York.

Schultz, Th. (1983): Beruházás az emberi tőkébe. Közgazdasági és Jogi Könyvkiadó, Budapest.

Sík Endre (2012): A kapcsolati tőke szociológiája. Eötvös Kiadó, Budapest. 
Smith, A. (1992): Nemzetek gazdagsága. A gazdagság természetének és okainak vizsgálata. Közgazdasági és Jogi Könyvkiadó, Budapest.

Tremblay, K., Lalancette, D., Roseveare, D. (2012): AHELO: Feasibility Study Report: Design and Implementation. Organisation for Economic Cooperation and Development, Paris.

Varga Júlia (1998): Oktatás-gazdaságtan. Közgazdasági Szemle Alapítvány, Budapest. 


\section{TORGYIK JUDIT}

\section{Multikulturalizmus, interkulturális nevelés}

Napjaink társadalmai mind komplexebb rendszerek, egyre bonyolultabb szisztémák mentén írhatók le. A hétköznapi és a szakmai élet szintjén egyaránt növekvő mértékű a különböző népek, népcsoportok érintkezése, a saját, megszokott kultúránktól eltérő kultúrákkal (normákkal, értékekkel, szokásokkal, hagyományokkal, nyelvekkel, viselkedési formákkal stb.) való találkozás esélyének gyakorisága. A társadalmi sokféleség megtapasztalása a gyermekek körében is mindennapos jelenségnek számít. A fejezet bemutatja a multikulturális nevelés kialakulásának hátterét, fogalmát, lehetséges értelmezési kereteit és fontosabb vizsgálati területeit.

\section{A multikulturális/interkulturális nevelés társadalmi, történeti háttere}

A multikulturális/interkulturális nevelés megjelenése több egymással párhuzamosan ható, különböző társadalmi folyamat együttes eredménye. Ezek egyike a nyugat-európai társadalmak multikulturálissá válása, amely történetileg a második világháború utáni gazdasági fellendülés időszakára vezethető vissza. A gyarmatbirodalmak felbomlása után, az 1950-es évektől kezdve, az egykori gyarmatokról mind többen kerestek új otthont maguknak a volt anyaországban (pl. Nagy-Britanniában, Franciaországban, Hollandiában, Belgiumban). Másrészt a nyugat-európai országok gazdasági fejlődéséhez nagy szükség volt a kelet erejére, ezért külföldi munkásokat toboroztak a világháború utáni újjáépítéshez. Az 1960-as években egyre 
több vendégmunkás érkezett, akik kezdetben csak ideiglenesen, később azonban tartósan, végleg maradni kívántak a befogadó országban. Családtagjaik, gyermekeik fokozatosan csatlakoztak hozzájuk, telepedtek át az új országba. A nemzetközi migráció során a szegénység, a munkanélküliség, a válsághelyzet „nyomó hatásnak” (push effects) számít, míg „húzó hatású" a tanulás és a kedvező elhelyezkedés lehetősége, a magasabb jövedelem, a jobb megélhetés esélye (pull effects). Mind többen költöztek a jobb élet reményében a fejletlenebb keleti országokból a fejlett nyugatra, valamint a déli államokból északra. A nyolcvanas években a korábban kivándorlónak számító országok (pl. Olaszország, Spanyolország) is kezdtek etnikai szempontból átalakulni, s az Európán kívüli, főleg afrikai migránsok számára mindinkább célországgá válni (Kardos és Radó, 1999). A második világháború utáni migrációs folyamatok nem csak a gazdaságot, hanem a társadalmat, annak alrendszereit, köztük az oktatásügyet is változásra késztették (Luchtenberg, 2004). Az eltérő kultúrák tudományos megismerésének kifejezett igénye a népesség mozgásának erősödésével került egyre inkább előtérbe a neveléstudományban is.

A migráció kérdése a közép- és kelet-európai országokat is érinti, ezekben az országokban is jelen vannak a bevándorlók, azonban arányukat tekintve jóval alacsonyabb számban, mint a nyugat-európai országokban. Hazánk és a többi volt szocialista ország jóval inkább tranzitország, mint célország a migránsok számára. Mindemellett azonban Közép- és Kelet-Európa országai sem tekinthetők monokulturálisnak, tekintve, hogy az itt élő népek, népcsoportok történelme ugyancsak évszázadok óta összefonódik más népek életével, történetével, befogadásával, az őshonos kisebbségek jelenlétével. Európa-szerte határokon átnyúlóan számos nemzetiség és etnikai kisebbség él évszázadok óta együtt. Az első világháború után a történelmi határok változásai nyomán az anyaország határain kívül rekedt csoportok számára anyanyelvük, kultúrájuk megőrzése, ápolása jelent kihívást (Luciak, 2004). Közép- és Kelet-Európa országaiban a nemzetiségek, etnikai kisebbségek helyzetével való foglalkozás az 1989-90-es rendszerváltás utáni időszakban került az érdeklődés előterébe, különösen a cigányság helyzete vált az általános társadalmi diskurzusok részévé (Forray, 
2013; Liégeois, 2002, 2009). A rendszerváltással mindinkább felszínre kerültek a kisebbségeket érintő, eddig kibeszéletlen kérdések, s mind láthatóbbá váltak a hiányok és szükségletek, majd a volt szocialista országok oktatásügyében is fokozatosan helyet kapott a többi kisebbségi csoportra való odafigyelés, társadalmi sokféleséggel kapcsolatos diskurzus és reflexió.

A multikulturális/interkulturális nevelés európai megerősödését további szempontok is befolyásolták, ezek egyike az Európai Unióhoz köthető, amely fejlődése során az 1980-as évek óta fokozatosan új gondolatokkal bővítette a multikulturalizmus eszméjét. Az Unió mint gazdasági, társadalmi közösség számtalan kulturális hagyományra épülő nemzet szövetsége, amely a humanizmust és a társadalmi kohéziót közös európai célnak tartja. Az Európai Uinióban kiemelt jelentőséget kap a demokratikus értékek, az európai kultúra és a nyelvi, kulturális sokféleség megőrzésének gondolata. Megjelent az „európai identitás” formálásának igénye, és az oktatásban, az uniós dokumentumokban helyet kapott az „európai dimenzió” eszméje. „Az oktatás egyik feladata, hogy megismertessen az európai és multikulturális demokratikus értékekkel, és számos különböző európai kultúrával. (...) Az oktatásnak páneurópai szemléleten kell alapulnia, hogy minden polgár felismerje a nemzeti sajátosságok mögött meghúzódó, európai civilizációban rejlő értékeket." (Állásfoglalás az oktatás európai dimenziójáról készült Zöld Könyvröl, 1994:98).

Mindezzel párhuzamosan a multikulturális/interkulturális nevelés fejlődését a globalizáció jelensége további szempontokkal bővítette. A globalizáció ugyancsak növeli a multikulturalitás jelenségét. A globalizáció révén az áruk, a munka, a tudás nemzetközi áramlása gyorsabbá vált. Az infokommunikációs technológiák és a közlekedés fejlődése, olcsó elérhetősége földrajzi helytől függetlenül ösztönzi az egyének közötti új kapcsolatok megteremtését, növeli a lehetséges találkozások számát a diákok szintjén is (pl. social media) (Watson, 2004). A távoli tájak elérése, a középréteg körében a külföldi utazások általánossá válása, az uniós mobilitási programok mind több tanuló számára adnak alkalmat az eltérő országokkal, kultúrákkal, népek tagjaival való kapcsolat személyes megélésére. Ami azonban még ennél is fontosabb, hogy a globalizá- 
ció következtében a munkahelyek világában is nagyobb esély van más kultúrához tartozó - eltérő szokásokkal, viselkedési formákkal, nyelvvel bíró emberekkel együtt dolgozni, mint bármikor korábban (Schields, 2013). A 21. században azok az országok képesek sikeresen fejlődni, amelyek a kötelező iskolázás évei alatt felkészítik állampolgáraikat a sokszínű, globális társadalomban való boldogulásra, azaz felruházzák őket olyan tudással, képességekkel és attitűdökkel, amelyek a modern világban, nemzetközi környezetben való sikeres élethez szükségesek.

A 2001. szeptember 11-ei terrortámadás óta a multikulturalizmus világszerte új kihívásokkal néz szembe. Ez az esemény és további terrorcselekmények mindinkább felhívják a figyelmet a marginális helyzetben lévő társadalmi csoportok szükségleteinek értelmezésére, elemzésére, s egyúttal még hangsúlyosabbá vált a globális egymásra utaltság világában az interkulturális és az állampolgári kompetenciák fejlesztése, a társadalmi kohézió erősítése.

2004 után az Európai Unió bővítésének folyamata újabb lendületet adott a népmozgásoknak, a munkavállalás megkönnyítése az újonnan csatlakozott országokban új migrációs hullámot indított el. Míg a régi tagállamok kedvelt bevándorló országnak számítanak, addig az új országok jóval inkább kivándorló országok közé tartoznak. Ezt a folyamatot a 2008ban kitört gazdasági világválság tovább erősítette. A hirtelen munkanélkülivé vált, hiteleikkel küzdő családok tömegei az új tagállamokból a régi uniós tagállamokban és az észak-amerikai államokban kerestek megoldást és megélhetést. Sokan családdal, gyermekkel együtt vándoroltak ki, mások gyerekeiket családtagokra hátra hagyva indultak útnak. Mindemellett a nemzetközi migrációt - az unión belül és határain kívül is - napjainkban további társadalmi jelenségek, konfliktushelyzetek mozgatják, amelyek az új tagállamokat is érintik - a kivándorlás után nálunk is megjelent a bevándorlás, és az ezzel való foglalkozás az oktatásügyet sem hagyja érintetlenül. 


\section{A multikulturális/interkulturális nevelés fogalma és jelentése}

Noha a nyugat-európai társadalmak iskolarendszerei kezdetben nem szenteltek különösebb figyelmet a migránsok gyermekeinek, a későbbiekben azonban a társadalmi változások hatásaival az oktatásban is szembe kellett nézni. A modernizáció felerősödése megújulást hozott a neveléstudományban, tekintve, hogy a társadalmi, nyelvi, gazdasági és kulturális sokféleség nagyban befolyásolja a tanulás körülményeit és esélyeit, s jelentős hatással van az iskola világára is (Gogolin és Krüger-Potratz, 2010).

Ilyen viszonyok között jött létre a multikulturális/interkulturális nevelés, amely ma már a nevelés önálló területeként értelmezhető. Kezdetben egy-egy csoportra koncentrált - elsősorban a migránsokra, nyelvi és etnikai kisebbségekre, a későbbiekben azonban a társadalmi sokféleség valamennyi aspektusának nevelési, oktatási vonatkozása fokozatosan a pedagógiai diskurzusok részévé vált. A multikulturális/interkulturális nevelés célja, hogy a társadalomban jelen lévö, az iskolára ható nyelvi, etnikai, kulturális, vallási, szociális, nemi, földrajzi, képességbeli különbségekre az iskolarendszer adekvátan reagáljon, s megfelelő pedagógiai választ adjon. Feladata, hogy a felnövekvő generációk olyan ismeretekkel, képességekkel és attitüdökkel rendelkezzenek, amelyek hozzájárulnak a sokszínü társadalomban való sikeres és eredményes élethez (Gogolin és Krüger-Potratz, 2010). Célja szerint mind a többségi, mind pedig a kisebbségi diákok személyiségének formálását, az oktatásban, nevelésben az egyenlö esélyek biztosítását szolgálja (Banks, 2011).

A neveléstudományi szakirodalomban nemzetközi szinten egyaránt találkozhatunk mind az interkulturális, mind a multikulturális nevelés fogalmával. Az észak-amerikai (amerikai egyesült államokbeli, kanadai) továbbá Európában a holland, valamint a brit terminológia a multikulturális nevelés fogalmát használja, míg más európai országok (pl. Németország, Ausztria, Franciaország) inkább az interkulturális kifejezést részesítik előnyben (Gogolin és Krüger-Potratz, 2010). Hazánkban mindkét fogalom használatos a neveléstudományi szakiroda- 
lomban (vö. Forray, 2013; Gordon Győri szerk. 2014; Torgyik és Karlovitz, 2006), s alapvetően elfogadhatjuk, hogy egymás szinonimájának tekinthetők. Allemann-Ghionda (2011) hangsúlyozza, hogy az interkulturális nevelés kifejezésben az „inter-” előtag az interaktív megközelítést érzékelteti, míg a multikulturális kifejezésben a „multi-” előtag a kultúrák sokféleségre utal, amelyek ugyanazon földrajzi területen élnek vagy amelyeknek tagjait ugyanabban az intézményben oktatják. Gyújtőfogalomról van szó, amely számos különböző neveléstudományi és interdiszciplináris elméletet, megközelítést és intézményi gyakorlatot rejt magában.

A multikulturalizmus jelensége nem csupán a neveléstudományra van hatással, hanem számos humán- és társadalomtudományi területet és szakmát érint, köztük a szociálpszichológia, a kulturális pszichológia, a közgazdaságtan, az egészségügy, a szociális munka stb. terén ugyancsak új szempontokat hozott. Megfigyelhető ebben a vonatkozásban az interdiszciplináris kutatások végzése, különböző tudományágak kölcsönhatásának erőteljes érvényesülése.

\section{A multikulturális/interkulturális nevelés megközelítései}

A multikulturális/interkulturális nevelés számos szempont mentén közelíthető meg. A következőkben bemutatásra kerülő szempontok néhány lényeges kérdésre világítanak rá, azonban érdemes figyelembe venni, hogy a fejlődés és a társadalmi háttér változásai hatására újabb és újabb területekkel bővülnek.

A multikulturális/interkulturális nevelés történeti genezise szorosan összekapcsolódott az emberi jogi és a gyermekjogi tudatosság társadalmi, politikai megerősödésével. Ehhez vezető első lépés az 1948-ban elfogadott Emberi Jogok Egyetemes Nyilatkozata volt, amely kimondja, hogy a nevelésnek az emberi jogok tiszteletben tartásával kell történnie, elősegítve a türelmet, a barátságot és a népek, nemzetek, csoportok közötti kölcsönös megértést. A világháború tanulságai, illetve a további nemzetközi konfliktusok megelőzése az emberi jogok megerősítését célozta. A későbbiekben további nemzetkö- 
zi megállapodások, egyezmények, nyilatkozatok, deklarációk egészítették ki a fentieket, kimondva a nyelv, a kultúra, a sokféleség őrzésének, ápolásának jogát és lehetőségét, ösztönözve mindezek oktatásügyi támogatását. Az 1960-as évek amerikai polgárjogi mozgalma ugyancsak az egyenlő jogok és a megkülönböztetés megszüntetésének elérését szorgalmazta, a társadalmi igazságosság érdekében a kirekesztett csoportok - afroamerikaiak és más kisebbségek számára. Ez a folyamat hatást gyakorolt az európai társadalmi reformokra, köztük az oktatás változásaira is.

$\mathrm{Az}$ emberi jogok egyetemlegesek, minden embert megilletnek, így mindenkinek joga van a tanuláshoz, a megfelelő oktatásban való részvételhez. Az emberjogi aktivisták a szolidaritást, a társadalmi kohézió erősítésének fontosságát hangsúlyozták Nyugat-Európában is, amikor az iskola és az oktatás felelősségét emelték ki a migránsok oktatásának megfelelő megszervezésében az 1960-as években. Később az emberjogi mozgalomnak a multikulturális/interkulturális nevelés vonatkozásában az állampolgári kompetenciák fejlesztésben lett meghatározó szerepe ( $p l$. társadalmi, történelmi események több szempontú megismertetése, a hatalom mozgatórugóinak megértetése, a diszkrimináció tilalma stb.) (Batelaan és Coomans, 2008; Forray, 2013; Kozma, 2012).

Az 1960-as és az 1970-es években, a multikulturális/interkulturális nevelés fejlődésének kezdetén a teoretikusok és az iskolai gyakorlat szintjén dolgozók alapvetően deficit elméletből indultak ki, azaz a migránsokra, a kisebbségek tagjaira úgy tekintettek az intézményes nevelésben mint deprivált, valamiIyen hiánnyal, hátránnyal rendelkező tanulóra (Banks, 2011, Forray, 2013). Abból feltételezték, hogy a kisebbségi gyerekek kevésbé ismerik az ország nyelvét, kultúráját, marginális helyzetben vannak. Ily módon munkájuk során alapvetően a hátrányok kompenzálására, a hiányok pótlására helyezték a hangsúlyt. Ekkor még a gyerekek kulturális jellemzőivel kevésbé törődtek, a migráns tanulók iskolai gondjaira elsősorban szociális problémaként tekintettek. Miközben a kisebbségi tanulók háttere igen változatos, oktatásszociológiai tény, hogy a diákok tanulmányi előmenetelére jelentős hatást gyakorol a család szocioökonómiai helyzete, a szegénység, a szülők jöve- 
delme, a nyelvtudás milyensége. Ez az elképzelés alapvetően szociálpedagógiai, család- és gyermekvédelmi törekvésekkel, a hátrányos helyzet, a veszélyeztetettség, az esélyegyenlőség kérdésének általános hangsúlyozásával kapcsolódott össze. A hiányokra fókuszálva a kisebbségi tanulók és szüleik számára a segítségnyújtás legkülönbözőbb formáit szervezték meg, a beilleszkedés elősegítése érdekében: kompenzációs programokat, különórákat, délutáni foglalkozásokat nyújtottak, megszervezték a nyelvoktatást, asszisztenseket és más segítő személyeket biztosítottak a gyerekek és a pedagógusok számára, a szülők támogatását is elérték, a felnőttek képzését ugyancsak számos országban megszervezték.

A multikulturális/interkulturális nevelés nyelvi megközelítése a nyelvtudás hiányosságaira reagált. Megjelentek a nyelvtanulással kapcsolatos kutatások, továbbá a pedagógiai gyakorlatában lényeges szemponttá vált a kisebbségi tanulók és szüleik idegen nyelvi kompetenciáinak fejlesztése, mely a társadalmi beilleszkedést, a jobb iskolai eredmények elérését ösztönözte. Kezdetben úgy vélték, a nyelvi hiányosságok megoldása az iskolai sikerességet biztosítani fogja, a későbbiekben azonban rájöttek, hogy a nyelvi fejlesztés szükséges, de önmagában nem elégséges az eredményes iskolai részvételhez, illetve a társadalmi integrációhoz. A befogadó országok többféle módon támogatták az új ország nyelvének megtanulását: kétnyelvű programokat szerveztek, intenzív kurzusokat hirdettek, tanórán kívüli fejlesztési lehetőségeket nyújtottak, a szülőknek kétnyelvű tájékoztató anyagokat készítettek, iskolai rendezvényeken tolmácsokat biztosítottak ( $A$ bevándorlók gyermekeinek integrációja..., 2008). Másutt a migránsok anyanyelvének megtartását szintén támogatták (pl. Svédországban). Az oktatáskutatók vizsgálni kezdték, hogy mi jellemzi a nyelvi szocializációt, a nyelvelsajátítás folyamatát többnyelvű környezetben. A kapcsolódó nyelvpedagógiai kutatások a nyelvváltás, a nyelvvesztés, a kétnyelvü, többnyelvű iskolai programok, jól működő gyakorlatok jellegzetességeinek megismertetését ugyancsak célozzák.

Az 1980-as évekre a nyugat-európai közoktatásban a migráns tanulók jelenléte mindinkább elfogadottá vált. Az osztálytermekben fokozatosan megjelent a migráns tanulók kultúrá- 
jára való tudatos odafigyelés, az elfogadás, integrálás, majd $a z$ inkluzivitás. A migráns gyerekek tömeges, hosszabb idejü jelenléte nyomán a szakemberek belátták, hogy el kell fogadniuk a társadalmi változások iskolai hatásait, s szükségessé válik ennek intézményes, adekvát pedagógiai kezelése is. Kezdetben mindössze egy-egy projektnap, projekthét formájában, alkalmi rendezvényeken foglalkoztak a bevándorlók kulturális sajátosságaival, ünnepeivel, szokásaival, hagyományaival, illetve az iskolai faliújságokon adtak helyet a külföldi diákok világának. Később azonban a kérdés feldolgozása nemcsak egyegy napra szorítkozott, hanem a tankönyvekbe, a tantervbe is mind jobban bevonult. Fokozatosan eljutottak oda, hogy nem csupán a gyerekektől várták el az iskola rendjéhez, szabályaihoz való alkalmazkodást, hanem a szemléletváltás részeként, az iskolák múködésük során maguk is alkalmazkodtak a diákok kulturális vonásaihoz, világához. Figyelembe vették és elfogadták annak sajátos jellemzőit ( $p l$. az eltérő étkezési szokásokat a menzán, a hiányzások mérlegelésekor az adott vallásra jellemző ünnepnapokat, illetve az egyes tevékenységek - köztük a testnevelés - szervezése során a kulturális igényeket stb.). Ennek mértéke - mit engednek, mit tiltanak - azonban országonként a nyitottság mértékétől függően változott ( $A$ bevándorlók gyermekeinek integrációja..., 2008). Mindeközben a nyugat-európai pedagógusképzés ugyancsak átalakult, elindultak azok a képzések és továbbképzések, amelyek felkészítették a tanárokat a migránsokkal való foglalkozásra. Szakdolgozatok, doktori munkák, könyvek, szakcikkek születtek a témában, s egyre inkább intézményes helyet kért magának a neveléstudományon belül e kérdés tanulmányozása (Gogolin és KrügerPotratz, 2010).

A multikulturális/interkulturális nevelés fejlődésének következő állomása a társadalomban jelen lévő sokféleség reflexiója, a sokféleség megértése, elfogadása, a multiperspektivikus szemléletmód felerősödése (Banks, 2011). A multikulturális/ interkulturális nevelés kezdetben az oktatási rendszerben megjelenő etnikai különbségek megismerésére és megértésére fókuszált, későbbiekben azonban, a fogalom egyre tágabb értelmezést nyert. Napjainkban, a társadalomban jelen lévő sokféleség - köztük az etnikai, nyelvi, szociális, vallási, nemi, 
életkori, földrajzi, képességbeli stb. - neveléstudományi vonatkozásait vizsgálja. Időközben nem csupán a migránsok, hanem a kisebbségek más csoportjai, köztük a speciális nevelési szükségletekkel rendelkezők, a tehetségesek, a vallási kisebbségek, a különböző nemek stb. pedagógiai vonatkozásai ugyancsak mindinkább figyelmet kapott az oktatásügy tudományos kutatásában (Kozma, 2012) és gyakorlati világában. A haladó szellemiségű kutatók, oktatók, civilek azt kívánták, hogy már ne egyszerűen migránsokról, külföldiekről beszéljenek, hanem egyre szélesebb értelemben figyeljenek a diákság jellemzőire, igényeire, szükségleteire. A többi kisebbség is hallatta hangját, s az oktatásügy demokratizálódása jegyében mind professzionálisabbá vált a tanulókkal való foglalkozás, számos vizsgálat eredményeként az interkulturális pedagógia rengeteget fejlődött. A kezdeti, kényszerű fogadás mostanra befogadássá, inklúzióvá változott, azaz össztársadalmi, illetve európai uniós szinten jelentkezik a sokféleség elfogadása s a vele való szakszerü pedagógiai foglalkozás.

A fenti folyamatok megjelenése hazánkban és a többi volt szocialista országban a rendszerváltás után vált érzékelhetővé. Mostanra hazánkban is megjelentek a migránsok, a velük való foglalkozás ugyancsak nevelésszociológiai kutatások tárgyát képezi (lásd Feischmidt és Nyíri szerk., 2006), miközben növekvő tudatosság figyelhető meg a többi kisebbségi csoport köztük pl. a speciális szükségletekkel rendelkezők - fejlesztése terén is. Az unióhoz való csatlakozás hazánkban is elhozta az oktatás európai dimenziójával, az interkulturális kompetenciákkal való foglalkozást, s közben a globalizáció hatásai is elérték Magyarországot. A befogadó társadalom, az inkluzív iskola elérése Európa közép és keleti felén is közüggyé vált.

A következőkben - a teljesség igénye nélkül - a multikulturális/interkulturális nevelés néhány, párhuzamosan futó fő kutatási területét mutatjuk be hazai és nemzetközi szinten.

\section{A tanuló iskolai sikerességének/teljesítményének vizsgálata}

A multikulturális/interkulturális neveléshez kapcsolódó kutatások gyakran összekapcsolódnak a kisebbségi diákok iskolai teljesítményének vizsgálatával, azzal a kérdéssel, hogy milyen 
tényezők befolyásolják a jó tanulmányi eredményeket. Ennek hátterében alapvetően a jobb iskolai eredmények elérése, támogatásának igénye, továbbá a lemorzsolódás arányainak csökkentése áll. Mind az egyén, mind a társadalom közös érdeke, hogy valamennyi tanuló - függetlenül egyéni és kulturális jellemzőiktől - képes legyen a tankötelezettség évei alatt olyan kompetenciákra szert tenni, amelyekkel felnőttként foglalkoztathatóvá válik, s megállja a helyét a munkaerőpiacon.

Marcelo és Carola Suárez-Orozco (2011) hangsúlyozzák, hogy a kisebbségi diákok igen változatos környezetből érkeznek, különböznek nyelvük, vallásuk, tudásuk, iskolázottságuk, származási országuk, teljesítményük tekintetében, vannak közöttük kifejezetten sikeres tanulók, ugyanakkor lemaradók is. Vizsgálataik szerint a jó iskolai eredményeket a kisebbségi diákok között több tényező együttesen befolyásolja. Így 1) a szülők iskolai végzettsége és a tanulás értéke a családban; 2) a család szociális, gazdasági helyzete; 3) a társas támogatás mértéke (családi, rokoni, tágabb közösségi, baráti, iskolai, mentori); 4) a tanuló nyelvtudásának milyensége; 5) motiváltsága, elkötelezettsége a tanulás, az iskola, az intézményi kapcsolatok iránt, továbbá 6) az iskolai oktatás minősége, jellege (integrált vagy szegregált oktatás), a pedagógusok elvárásai. Székelyi és mtsai (2005) sikeres életpályát befutott cigány felnőttek körében vizsgálódva arra a megállapításra jutottak, hogy a siker elérésében igen nagy szerepe volt gyermekkorban a támogató pedagógusoknak, különösen, ha a családi környezetben nem volt támogató személy, továbbá azok a gyerekek tudtak leginkább integrálódni, akiknek a barátai között a szomszédságban, az iskolában a többségi gyermekek jelen voltak. Mindemellett a megkérdezett személyek eredményeihez nagyban hozzájárult pozitív énképük, önbizalmuk, önmagukba vetett hitük.

A kisebbségi gyerekek iskolai sikerességének vizsgálata magában foglalja a továbbtanulási arányok, statisztikák, a szakképzésben az érettségit adó iskolákban és a felsőoktatásban való részvétel és eredményesség kutatását is (Gogolin és Krüger-Potratz, 2010). Az utóbbi években nemzetközi szinten a PISA-felméréssel kapcsolatban (lásd Papp, 2014) figyelhető meg a kisebbségi és a többségi tanulók teljesítményének kvantitatív összehasonlítása, a siker háttértényezőinek, oka- 
inak kutatása. A rezilienciavizsgálatok arra keresik a választ, hogy mi befolyásolja a nehézségekkel való megküzdést, miIyen tényezők teszik ellenállóvá, edzetté az egyént, illetve az iskolát a jó eredmény elérésében, a boldogulásban.

\section{Az interkulturális nevelés mint az identitás és az életút vizsgálata}

A multikulturális/interkulturális nevelés empirikus kutatói körében az 1980-as évektől megtaláljuk az egyéni élettörténetek, a szocializáció során szubjektíven megélt életvilágok tudományos igényű feltárására való törekvést. Itt kaptak helyet a biográfiai (életút-) kutatások, amelyek a kisebbségi helyzetben lévő egyén életére, illetve annak egyes szakaszaira, eseményeire fókuszálnak, narrációk révén ismerik meg gyermekkorát, iskolai élményeit, vizsgálják iskolán kívüli tanulási mintázatait, kapcsolatrendszerét, visszaemlékezéseit. A pedagógiai és az andragógiai életútkutatások számos ponton gazdagítják az interkulturális nevelést, a neveléstudományi megismerést. A biográfiai kutatás kvalitatív módszerekkel dolgozik, önéletrajzokra, személyes beszámolókra, szubjektíven megélt élethelyzetek, kapcsolati minták feltárására, feldolgozására, az identitáskonstrukciók megismerésére koncentrál. A kutatók elemzik az egyéni tanulástörténeteket, bemutatják az egyén által megélt gyermekkort a különböző kultúrákban és élethelyetekben, illetve a sokféle társadalmi jellemző függvényében. Saját életrajzi beszámoló alapján vizsgálják az identitást, ennek részeként az iskolázás folyamatát gyerekek, felnőttek és kamaszok személyes történetei alapján (Renner, 2006; DeloryMomberger, 2007). A személyes és szakmai életút vizsgálata történhet például migráns, nemzetiségi, etnikai, vallási kisebbséghez tartozó, tehetséges személyek, speciális nevelési szükségletű gyerekek esetében, nők és férfiak körében (pl. tanulástörténet, iskolai szocializáció, identitás megélése), egyéni vagy fókuszcsoportos interjúk, megfigyelések, terepmunka, naplók, képek, fotók, magánjellegű dokumentumok megismerése útján. Mindezek azt mutatják, hogy a szocializációs folyamat során az identitás alakulása, formálódása messzemenően komplex, az egyén oldaláról szubjektíven megkonstruált, ér- 
zelmekkel átszőtt folyamat. Phillion (2002) narratív multikulturalizmusnak nevezi az egyén mindennapi tapasztalatainak megértésére, megismerésére törekvést, melynek középpontjában az emberi létezés sokfélesége áll, és amely szituativ, reflektív és személyiség-központú jegyeivel viszonylag új perspektívákat hoz az interkulturális tapasztalatok vizsgálatához, a gyermekek megismeréséhez a neveléstudományba.

A multikulturális/interkulturális nevelés kutatói között az énkép, az önbizalom, az identitás vizsgálata kedvelt témakör. Nem mellékes, hogy a pozitív énképpel, önbizalommal rendelkező diákok sikeresebben veszik az iskolai akadályokat, könnyebben megküzdenek feladataikkal. Az önmagunkba vetett hit, a pozitív énkép fejleszthető, formálható, s ebben a folyamatban különösen nagy szerep jut a külső tükröknek, a szülőknek, a pedagógusoknak és a kortárs csoportoknak. A kiközösítésnek, csúfolásnak, az előítéleteknek és sztereotípiáknak kitett diákok hamarabb feladják a küzdelmet, mint azok a diákok, akik tanulmányaik során rendre pozitív visszajelzéseket kapnak. Az énkép, a személyiség értékeinek megerősítése hozzájárul a jó iskolai eredmények eléréséhez, a tanulmányi sikerekhez, a tanulás megszerettetéséhez. A korábbi deficitorientáció helyébe a progresszív szellemiségú interkulturális nevelésben az erősségekre való összpontosítás, a személyiség pozitivumainak tudatos elismerése, a "képes vagy rá" orientáció lépett. Valamennyi embernek vannak értékes tulajdonságai. A pedagógusok pozitív visszajelzései, fejlesztő értékelése további lendületet adnak, támaszt nyújtanak a tanuláshoz és a leendő munkához. (Gay, 2000; K. Nagy, 2012)

\section{A multikulturális/interkulturális nevelés mint kompetenciafejlesztés}

A multikulturális/interkulturális nevelés a kompetenciafejlesztés feladataként is jelentkezik. Az iskolának abban kell segítenie diákjait, hogy kibontakoztathassák képességeiket, s felnőttként is megfelelően megállják helyüket a sokszínú társadalomban. A vonatkozó kutatások és elméleti munkák arra fókuszálnak, hogy milyen tudás, képességek és attitűdök szükségesek a többségi és a kisebbségi tanulók számára a multikulturális környezetben 
való sikeres élethez. E tekintetben személyközi, interkulturális és szociális kompetenciák fejlesztéséről beszélünk, amelyek ma már közös, európai szinten elfogadott kulcskompetenciának számítanak (vö. NAT). A nyitottság, rugalmasság, tolerancia, más kultúrák iránti érdeklődés, a megismerés igénye, megfelelő nyelvtudás, empátia, jó kommunikációs és konfliktusmegoldó képesség, önreflexió, együttmúködési képesség stb. mind olyan kompetenciák, amelyek a pozitív személyközi kapcsolatok kialakítását szolgálják. Alakításuk a szociális tanulás részét képezi (Auerheimer, 2007a, 2007b; Laufrauchi, 2002), amelynek támogatása az oktatási rendszer minden szintjén jelentkezik. Az egymást megismerő, egymással érintkező egyének kölcsönösen hatással vannak egymás életvilágára, személyiségére, gondolkodására és magatartására. Számos vizsgálati eredmény mutatja, hogy az interkulturális kompetenciák fejlesztése pozitív hatással van az elfogadásra, az előítéletes, sztereotip magatartásformák csökkentésére (Allport, 1977; Aronson, 2009), mellyel elérhető a másik ember iránti idegenkedés oldása, növelhető a tolerancia, az elfogadás, hosszabb távon megerősíthető a befogadó, inkluzív társadalom. A kognitiv szférát és az érzelmeket együttesen megérintve, az aktív részvételre alapozva feloldhatók a másik iránti félelmek, szorongások, tévhitek.

Másrészt az interkulturális tanulás egyúttal nagyban hozzájárul az állampolgári kompetenciák formálásához is. Az iskola feladata, hogy a diákok kritikus gondolkodását, vitakészségét, igazságérzetét, embertársai iránti szolidaritását, a demokratikus társadalomban az aktív állampolgári léthez szükséges viselkedésformákat fejlessze (Kozma, 2012). Megismertesse, tudatosítsa az emberi létezés sokféleségét, annak értékeit, társadalmi, etikai vonatkozásait, már a tankötelezettség évei alatt erősítse a szociális kohéziót, a demokrácia működésének megértése céljából gyakoroltassa a felelősségvállalást, a döntéshozásban, a közösségi tevékenységformákban való hatékony részvételt (pl. diák-önkormányzati munka, önállóan kivitelezett közösségi feladatok, társadalmi események több szempontú elemzése, értékelése).

Mára már rendelkezésre állnak azok a didaktikai módszerek és tevékenységi formák, amelyek révén kialakítható és hatékonyan fejleszthető egymás megismerése, megértése (Sielert és 
mtsai, 2009). Ide tartoznak a szituációs és szerepjátékok, viták, beszélgetések, megbeszélések, filmvetítések, projektmunkák, terepgyakorlatok, a kisebbségi csoport tagjaival való közvetlen találkozási alkalmak és közösen végzett tevékenységek s a körükben végzett empirikus vizsgálatok (interjúk, megfigyelések, esettanulmányok stb.), melyek saját élményű tanulásra, közvetlen tapasztalatszerzésre, értelmezésre, önreflexióra adnak alkalmat (Allport, 1977). A környezetünkben fellelhető sokféleség tudatosítása elgondolkodtat és minőségileg új szintre emeli az emberi viszonyokat. Az interkulturális és az állampolgári kompetenciák fejlesztése során a kooperativ technikák (Arató és Varga, 2008; K. Nagy, 2012), interakcióra, párbeszédre épülő csoportmódszerek alkalmazása arra mutat rá, hogy a kölcsönös függőségen alapuló, heterogén csoportban végzett feladatok jótékonyan hatnak az iskolai társas kapcsolatok alakulására, a különböző sajátosságokkal rendelkező tanulók beilleszkedésére, az elfogadás, az empátia mértékének javulására (Aronson, 2009), s nem utolsó sorban hozzájárulnak a kisebbségi tanulók tanulmányi eredményeinek növeléséhez is.

\section{A multikulturális/interkulturális nevelés mint az iskolai, osztálytermi gyakorlat vizsgálata}

A multikulturális nevelés osztálytermi vizsgálata ugyancsak széles körü. A kutatók jórészt arra keresik a választ, hogy miIyen pedagógiai sajátosságok jellemzik a mindennapokban a sokféleséget értékként elfogadó iskolát és a jó tanárt. Míg a multikulturális/interkulturális nevelés kezdetben egy-egy csoportnak (migránsoknak, nyelvi, etnikai kisebbségeknek) kívánt megfelelő iskolát, addig mára a minden gyerek számára hatékony, befogadó iskola elérése a célja, függetlenül a tanulók egyes tulajdonságaitól, kulturális jellemzőitől. A kapcsolódó kutatások döntően tanórai megfigyelésekre, esettanulmányokra, esetleírásokra épülnek, továbbá a „jó gyakorlatok” objektíven megragadható pedagógiai jellegzetességeinek bemutatására, leírására irányulnak.

Bár az iskolai gyakorlat a mindennapokban kétségkívül rendkívül változatos, mégis kitapintható néhány jellegzetesség, amely a minden gyerek számára jó iskola sajátja. Levine és 
Lezotte (2001) hatékony iskolákra vonatkozó kutatásai szerint, ezek a következők: 1) a jó iskolai légkör, a bizalomra, kölcsönös kommunikációra és együttműködésre épülő intézményi kapcsolatok (pedagógus, tanuló, szülő, további segítő szakemberek); 2) a tanulók egyéni sajátosságainak, humán szükségleteinek, szociokulturális jellemzőinek figyelembevétele; 3) a társadalmi sokféleséget értékként elfogadó, azt tükröző tanterv, tananyag; 4) befogadó pedagógus; 5) a közös célok érdekében elkötelezett nevelőtestület; 6) hatékony iskolaigazgató; 7) változatos oktatási módszerek, eszközök, értékelési formák; 8) a tanulási lehetőségek kibővítése, széles tevékenységkínálat biztosítása.

A tapasztalatok azt mutatják, hogy a hatékonyan múködő iskolák sokat merítettek a reformpedagógiák által képviselt értékekből. Alapvetően humánusak, gyermekbarátok, pozitív iskolai klímát alakítanak ki, szélesítik kapcsolataikat, nyitnak partnereik felé, a szülőkkel és a segítő szakemberek széles körével konstruktív együttmúködési formákra törekszenek, egymást segítő, kollegiális légkörben működnek. A szülőket bevonják az intézmény munkájába, kapcsolati problémák esetén alternatív utakat keresnek a kooperációra. Közös alapelvük az egyéni és a kulturális sajátosságoktól függetlenül az elfogadás, a kirekesztés elkerülése, a sokféleség értékként kezelése, a tananyagban, az iskolai mindennapokban sokféle szempont konstruktív megjelenítése. Pedagógusaik szakszerűen felkészültek, befogadó szemlélettel rendelkeznek, magas elvárásokat állítanak a diákokkal szemben, érzékenyek a tanulók problémáinak megoldása iránt, ösztönzik a csoportközi kapcsolatokat, a tanulók kompetenciáinak fejlesztését. Szakszerúen képesek segíteni, a tanulást támogatni (Gay, 2002). Figyelembe veszik és elfogadják a gyerekek egyéni és kulturális jellemzőit, rendszeresen felhasználják a diákok tapasztalatait, élményeit a nevelési folyamat során. A tanuló sajátosságait, környezetét figyelembe véve alakítják az iskola mindennapjait. Az oktatás során sikerélményt adnak, az önbizalmat, a pozitív énképet és identitást erősítik. Didaktikai módszereikben a változatosság, a modern pedagógia eljárások alkalmazása kerül előtérbe (Bárdossy, 2006; Torgyik és Karlovitz, 2006; K. Nagy, 2012), miközben fejlesztő értékelést alkalmaznak. Holisztikus 
szemlélettel dolgoznak, a tanulót annak családjával, társadalmi, kulturális környezetével, hátterével együtt szemlélik. Programjaikkal hozzájárulnak a szülők személyiségfejlődéséhez is. Támogatják az iskolán kívüli tapasztalatszerzést, tanulási helyszínek további bővítését célozzák.

$A z$ intézményi vizsgálatok között találunk olyanokat is, amelyek a pedagógusra fókuszálnak, kompetenciáik, vélekedéseik, nézeteik, oktatási módszereik jobb megismerése céljából. Jórészt arra kíváncsiak, hogy a sokszínű társadalmi háttérből érkező diáksághoz hogyan viszonyulnak, mennyire elfogadóak, hogyan tanítanak a pedagógusok, milyen pedagógiai módszertárral rendelkeznek, és hogyan értelmezik és kezelik munkájukban a diverzitást. Ebben a vonatkozásban Gordon Győri János és munkatársai (2014) vizsgálódtak, akik hazai pedagógusokat kérdeztek ki nézeteikről, vélekedéseikről. Eredményeik rámutatnak a gyakorló tanárok hárítására, interkulturális kompetenciáik hiányosságaira.

\section{A multikulturális/interkulturális nevelés mint a felsőoktatás vizsgálata}

A közoktatás kutatásán, elemzésén túl napjainkban mind több szakcikk, könyv jelenik meg a multikulturális/interkulturális nevelés felsőoktatási vonatkozásairól is ( $A$ bevándorlók gyermekeinek integrációja..., 2008). Vizsgálat tárgyát képezi a pedagógusképzés, a leendő pedagógusok szakmai felkészítésének módja, a hatékonyság növelésének elérése, valamint a gyakorló pedagógusok kompetenciáinak megfelelő fejlesztése, s ebben a képzők feladata és felelőssége. Összegyűjtötték azokat a didaktikai módszereket, amelyekkel a szakmai szocializáció során a hallgatók jó eredménnyel készíthetők fel a sokszínű környezetből érkező, a globális társadalom kihívásai között élő tanulókkal való foglalkozásra, pályájukra. A képzés során a pedagógusjelölt hallgató maga is kutatóvá válik, tanórai, illetve azon kívüli interkulturális jellegű megfigyeléseket végez, terepmunkán vesz részt, interjúkat készít, saját és mások személyiségére, kultúrájára reflektál. Mind az empirikus vizsgálatokban, mind pedig a témakör szakirodalmában elmélyül, miközben kezdőként tanítási gyakorlatot szerez a sokszí- 
nű háttérből érkező diákság nevelésében, oktatásában is. Az interkulturális tanulás a folyamatos önképzésnek és továbbképzésnek ugyancsak része, amelyet számos uniós ösztöndíj és szakmai továbbképzés támogat.

\section{Összefoglalás és kitekintés}

Összefoglalva a fentieket, a multikulturális/interkulturális nevelés napjainkra jelentősen megerősödött a neveléstudományon belül, a kezdeti periferikus helyzete megváltozott, mostanra mind centrálisabb pozíciót ért el. Vizsgált témakörei kiszélesedtek, kutatói egyre többet hallatják hangjukat, mostanra hatással van más rokon tudományokra, továbbá nemzetközi szinten születő összehasonlító vizsgálatok egymás fejlődésére is hatást gyakorolnak. A terület tudományos eredményeit önálló kiadványok, folyóiratok jelzik, a kutatói rendszeresen hazai és nemzetközi konferenciákat tartanak, képviselői az elmúlt évtizedekben, felsőoktatásban tanszékeket, intézeti csoportokat, BA és MA szakokat, továbbképzéseket hoztak létre. Témaköreihez kacsolódva magyar nyelven az Educatio, a Kisebbségkutatás, a Régió, a Romológia című periodikák közölnek tudományos kutatásokat, írásokat. Idegen nyelvű nemzetközi folyóiratai között említést érdemel a Multicultural Education, Journal of Cultural Diversity, Multicultural Perspectives, Intercultural Education, továbbá alkalmanként kapcsolódó szakcikkeket találhatunk az Iskolakultúra, a Zeitschrift für Pädagogik, továbbá a European Journal of Education című lapokban is. Az interneten a német nyelvű www. fachportal-paedagogik.de weboldalon vonatkozó szakmai anyagok (pl. iskolai projekteket stb.) közt kereshetnek a témában elmélyülni szándékozók. Számos idegen nyelvű szakkönyv és tanulmány érhető el a multikulturális/interkulturális nevelés terén a legnagyobb hazai könyvtárakon keresztül az EBSCO Discovery Service és az ERIC (www.eric.ed.gov) adatbázisból. Az Oktatáskutató és Fejlesztő Intézet, valamint az MTA Társadalomtudományi Kutatóközpont Kisebbségkutató Intézete rendszeresen publikál oktatásszociológiai, az oktatásügy sokszínűségéhez kötődő írásokat, s tart konferenciákat, múhelymunkákat. 


\section{Irodalomjegyzék}

A bevándorlók gyermekeinek integrációja az európai iskolákban In: Torgyik J. (2008, szerk.): Kulturálisan érzékeny iskola. Educatio Társadalmi Szolgáltató Közhasznú Társaság, Budapest, 27-50.

Állásfoglalás az oktatás európai dimenziójáról készült Zöld Könyvről (1994) In: Zarády Z. (2000, szerk.): Európa az iskolában - az iskola Európában. OKI Kutatási Központ, Budapest, 95-101.

Allport, G. W. (1977): Az elöítélet. Gondolat, Budapest.

Allemann-Ghionda, C. (2011): From intercultural education to the inclusion of diversity. Theories and policies in Europe In: Banks, A. J. (szerk.) The Routledge Companion to Multicultural Education. Routledge, New York, London, 9-33.

Arató Ferenc és Varga Aranka (2008): Együtt-tanulók kézikönyve, Educatio Társadalmi Szolgáltató Közhasznú Társaság, Budapest.

Aronson, E. (2009): Columbine után. Ab Ovo Kiadó, Budapest. Auerheimer, G. (2007a): Interkulturelle Kompetenz - ein neues Element pädagogischer Professionalität? In: Auerheimer, G. (szerk.) Interkulturelle Kompetenz und pädagogische Professionalität. Leske+Budrich, Opladen, 183-205.

Auerheimer, G. (2007b): Interkulturelles Lernen In: Göhlich, M., Wulf, Ch. és Zifras, Jö. (szerk.) Pädagogische Theorien des Lernens. Beltz Verlag, Weinheim und Basel, 15-162.

Banks, A. J. (2011): Multicultural education Dimensions and Paradigms. In: Banks, A. J. (szerk.) The Routledge Companion to Multicultural Education. Routledge, New York, London, 9-33.

Batelaan, P. és Coomans, F. (2008): Az interkulturális nevelés nemzetközi alapjai, beleértve az antirasszista és az emberi jogi nevelést is. In: Torgyik J. (szerk.) Multikulturális tartalmak a pedagógiában. Educatio Társadalmi Szolgáltató Közhasznú Társaság, Budapest, 81-110.

Bárdossy Ildikó (2006): A befogadó iskola és környezete, Új Pedagógiai Szemle, 3, 35-45.

Delory-Momberger, Ch. (2007): Biographisches lernen. In: Göhlich, M., Wulf, Ch., és Zifras, Jö. (szerk.) Pädagogische 
Theorien des Lernens. Beltz Verlag, Weinheim und Basel, 142-152.

Feischmidt Margit és Nyíri Pál (2006, szerk.): Nem kívánt gyerekek? Külföldi gyerekek magyar iskolákban. MTA Nemzeti-etnikai Kisebbségkutató Intézet, Budapest.

Forray R. Katalin (2013): Az idő fogságától szabadon - Tanulmányok a cigányság iskolázásáról és felemelkedéséről. Új Mandátum Kiadó, Budapest.

Gay, G. (2000): Culturally Responsive Teaching. Theory, Research and Practice. Teacher College Press, New York, London.

Gordon Győri János (2014, szerk.): Tanárok interkulturális nézetei és azok hatása az osztálytermi munkára: Kutatási eredmények. ELTE Eötvös Kiadó, Budapest.

Gogolin, I. és Krüger-Potratz, M. (2010): Einführung in die Interkulturelle Pädagogik. Verlag Barbara Budrich, Opladen and Farmington Hills, M.

Kardos Krisztina és Radó Péter (1999): Nemzeti kisebbségek, romák és bevándorlók oktatása az EU-ban és Magyarországon. Európai Tükör, 1. sz. 42-57.

K. Nagy Emese (2012): Több mint csoportmunka. Nemzeti Tankönyvkiadó, Budapest.

Kozma Tamás (2012): Oktatáspolitika. Debrecen-Pécs, k.n.

Laufrauchi, A. (2002): Interkulturelle Kompetenz als Element pädagogischer Professionalität - Schlussfolgerungen für die Lehrerausbildung. In: Auerheimer, G. (szerk.) Interkulturelle Kompetenz und pädagogische Professionalität. Leske+Budrich, Opladen, 206-234.

Levine, D. U., Lezotte és Lawrence, W. (2001): Effective School Research In: Banks, J. A. és Banks, Ch. A. McGee (2001): Handbook of Research on Multicultural Education. Jossey Bass, San Francisco, 525-547.

Liégeois, J. P. (2002): Kisebbségek és oktatás - cigányok az iskolában. Pont Kiadó, Budapest.

Liégeois, J. P. (2009): Romák Európában. Pont Kiadó, Budapest. Luchtenberg, S. (2004): Ethnic diversity and citizenship education in Germany. In: Banks, J. A. (szerk.) Diversity and citizenship education. Jossey-Bass, San Francisco, 245-273.

Luciak, M. (2008): Az etnikai kisebbségek iskoláztatása és az 
interkulturális nevelés: a legújabb tendenciák összehasonlítása a régi és az új EU-tagállamokban. In: Torgyik Judit (szerk.) Multikulturális tartalmak a pedagógiában. Educatio Társadalmi Szolgáltató Közhasznú Társaság, Budapest, 73-80.

Papp Z. Attila (2014): Selecting a Majority-Language School by Hungarian Minority Students, or From PISA Results Descourses in the Carpathian Basin. Minority Studies: Demography, Minority Education, Ethnopolitics, 17, 89-101. Phillion, J. (2002): Narrative Inquiry in a Multicultural Landscape - Multicultural Teaching and Learning. Ablex Publishing, Wasport, Connecticut, London.

Renner, E. (2006): Etnographie und interkulturelle pädagogishe Forschung In: Heinz-Herman Krüger, H-H. és Marotzki, W. (Hrsg.) Handbuch erziehungswissenschaftliche Biographieforshung. VS Verlag für Sozialwissenschaften, Wiesbaden, 137-170.

Sielert, U., Jaeneke, K., Lamp, F. és Selle, U. (2009): Kompetenztraining "Pädagogik der Vielfalt”. Juventa Verlag, Weinheim \& München.

Schields, R. (2013): Globalization and International Education. Bloomsburry, London, New Delhi, New York, Sydney.

Suárez-Orozco, M. M. és Suárez-Orozco, C. (2011): Globalization, Immigration and Schooling In: Banks, A. J. (szerk.) The Routledge Companion to Multicultural Education. Routledge, New York-London, 62-76.

Székelyi Mária, Örkény Antal, Csepeli György és Barna Ildikó (2005): A siker fénytörései. Sík Kiadó, Budapest.

Torgyik Judit és Karlovitz János Tibor (2006): Multikulturális nevelés. Bölcsész Konzorcium, Budapest.

Watson, J. L. (2004): Globalization in Asia - Antropological Perspectives In: Suárez-Orozco, M. és Qin-Hilliard, D. B. (szerk, 2004): Globalization Culture and Education in the new Millenium. University California Press, Berkeley, Los Angeles, London, 141-173. 



\section{FEHÉRVÁRI ANIKÓ}

\section{Társadalmi mobilitás és az iskola}

Hozzájárul-e az iskola a társadalmi mobilitáshoz? Képes-e az iskola a hátrányok kezelésére? Ilyen és ehhez hasonló kérdésekkel régóta foglalkozik már az oktatáskutatás. Ebben az írásban megkíséreljük bemutatni az egyenlőtlenségek és a társadalmi mobilitás oktatásra vonatkozó alapvető fogalmait, ismertetjük a téma legfontosabb nemzetközi és hazai szakirodalmát, rávilágítunk a magyar iskolarendszer elmúlt két évtizedes sajátosságaira, illusztrációként bemutatunk egy olyan oktatási programot, amelyben a felfelé irányuló mobilitás csatornái tetten érhetők.

\section{Társadalomszerkezet, egyenlőtlenségek és iskola}

A társadalmi mobilitásról nem beszélhetünk anélkül, hogy ne tisztáznánk a társadalomszerkezet és az egyenlőtlenség fogalmát. Arról is képet igyekszünk adni, hogy hogyan kapcsolódik össze a társadalmi egyenlőtlenség témaköre az oktatással és milyen meghatározó elméletek állnak mai gondolkodásmódunk hátterében.

A társadalomkutatók már régóta keresik a választ arra, hogyan értelmezhetők a társadalom differenciálódása, a társadalmi hierarchia, az egyenlőtlenségek. Az iparosodás megjelenésével a társadalmak legföbb rendező elvévé, a társadalmi hierarchiában betöltött hely legfontosabb ragsorolásának eszközévé a munkamegosztás vált. Marx szerint a társadalom osztályokra tagozódik, amelyet a termelőeszközökhöz való viszony határoz meg. Weber a gazdasági dimenzión - amelyet nemcsak a tulajdonviszonyok, hanem a munkamegosztásban 
elfoglalt hely is meghatároz - túl a társadalomszerkezet még további két dimenzióját különbözteti meg: a hatalmat és a társadalmi megbecsültséget (Weber, 1992).

A társadalmi csoportokat a szociológia klasszikusai, de a mai tudomány múvelői is másképp definiálják. Marx osztályokról, Weber rendekről ír. Az osztály fogalma helyett vagy mellett a 20. század első felében Geiger vezeti be a réteg elnevezést. Geiger azokat az egyéneket sorolta egy társadalmi rétegbe, akik bizonyos mutatók (pl. jövedelem, iskolázottság) alapján hasonló helyzetben vannak. Az osztály megközelítés alapvetően valamilyen elméleti nézőpont szerint különíti el a társadalmat osztályokra (Róbert, 1997), kategóriákban gondolkodik, amelyek nominálisak és graduálisak is lehetnek, vagyis nem feltétlenül hierarchikus viszonyt jelentenek. A réteg megközelítés ezzel szemben graduális jellegü, nem valamilyen elméleti nézőpont jelenti a besorolás alapját, hanem azok empirikus vizsgálatokon alapulnak (Huszár, 2013). Sokan vélik úgy, hogy a társadalom fejlődése maga után vonja a nagycsoportok, osztályok eltűnését és a csoporthatárok feloldódását. Angelusz (2000) és Beck (1992) szerint a modern társadalmakban már elmosódnak az osztályok és a rétegek közötti határok. A társadalmi egyenlőtlenségek szerkezete a fejlett országokban változatlan, ugyanakkor az emberek életfeltételei látványosan megváltoztak, ezért indokolt egy másfajta csoportosítási módot választani az eddigiek helyett, s ez az élethelyzet, életstílus. Vannak azonban olyan vélemények is (Esping-Andersen, 1993), amelyek azt hangsúlyozzák, hogy az osztályok nem tűntek el, csak a társadalom változott meg. Így a korábbi ipari társadalmakra vonatkozó rendezőelvek (tulajdon, hatalom, piac) helyett újakat kell keresnünk, amelyek a posztindusztriális társadalmakat jellemzik (pl. oktatás expanziója, szolgáltató szektor növekedése).

De miből fakadnak az egyenlőtlenségek? A rétegződési vizsgálatok klasszikusai Davis és Moore (1999) szerint nincs olyan társadalom, amely ne rétegződne, de az egyes társadalmak különböznek a rétegződés foka és fajtája szerint. A rétegződés úgy alakul ki, hogy a társadalomban egy szelekciós mechanizmuson keresztül minden egyén (teljesítménye, képessége szerint) a számára megfelelő helyre kerül, a különböző 
pozíciókhoz különböző jutalmak rendelődnek (funkcionalista megközelítés), a társadalmi egyenlőtlenség pedig ezekből az eltérő jutalmakból ered. A konfliktuselméleti megközelítés szerint az egyenlőtlenségek egyszerǔen a javakért folytatott harc során keletkeznek. Ehhez az irányzathoz tartozik például a marxi osztályelmélet vagy a bourdieu-i tőkeelmélet (Bourdieu 1999). Bourdieu szerint a társadalom felhalmozott történelem, a tőkefelhalmozás pedig nemcsak anyagi formában létezik. A gazdasági mellett létezik még kulturális és társadalmi tőke is, ahol ez utóbbi kettő gazdasági tőkévé konvertálható. Bourdieu több múvében is foglalkozik a társadalmi egyenlőtlenségek újratermelődésével, és az iskola ebben játszott szerepével (Bourdieu, 1978). Kutatási adatai szerint a munkáscsaládokból származó egyetemi hallgatók tanulmányi sikeressége jelentősen gyengébb volt a francia egyetemen, mint a polgári és a magasabb társadalmi csoportokból származó hallgatók esetében (Bourdieu, 1969). Felismeri, hogy nem egyszerüen diszfunkcionális múködésről van szó, hanem a társadalmi egyenlőtlenségek iskolai egyenlőtlenséggé alakulnak át, amelyek eltérő diplomák, végzettségek révén különböző karriereséllyel párosulnak, így ismét társadalmi egyenlőtlenséggé válnak. Véleménye szerint az oktatási rendszernek kettős funkciója van: egyrészt saját rendszerének, másrészt az adott társadalmi rendszernek a megőrzése. Ennek megfelelően az iskola hozzájárul az osztályviszonyok újratermelődéséhez, és mindezt úgy tudja leplezni, hogy közben az iskola az autonóm múködés látszatát kelti.

A magyar társadalom vizsgálata az első világháborútól az ötvenes évekig igencsak szegényes. Az első említésre méltó elemzés Ferge Zsuzsa (1969) nevéhez kötődik. Tanulmánya az egyenlőség mítoszát rombolta szét, mivel megállapítja, hogy a szocialista társadalom struktúrájában is vannak olyan csoportok, amelynek nagyobb az esélyük helyzetük javítására, míg másoknak kisebb. Kijelenti, hogy akik a tudás és/vagy hatalom magasabb szintjén állnak, jobban tudják érvényesíteni érdekeiket.

Ferge rétegződésvizsgálatában hét (aktív) csoportot különböztet meg munkájuk jellege alapján. ${ }^{1}$ Ezt a modellt módosította Andorka (1982) ${ }^{2}$, majd a magyar modellt több más nyugati modellel hasonlította össze (Giddens, Bolte, Haller, Blau, 
Lipset). Megállapította, hogy a modellek mindegyike visszanyúlik a Weber-féle munkamegosztás szerinti osztályfogalomhoz, illetve valamennyi modell a társadalmi egyenlőtlenségek mentén tagolja a társadalmat. Az elméleti hasonlóságok mellett Andorka azt is megállapítja, hogy a magyar modell igen hasonlít a kapitalista rétegkategóriákhoz, vagyis nem valósult meg a társadalmi egyenlőség eszménye (Andorka, 1995).

Míg Ferge és Andorka modelljében a foglalkoztatáson volt a hangsúly, addig Kolosi és Utasi modellje szerint a munkamegosztásban betöltött pozíció már kevésbé határozza meg az egyén helyét a társadalomban, az csak egyik jellemzője ${ }^{3}$. Kolosi 1987-ben megjelent Tagolt társadalom című munkájában az egyenlőtlenségek hierarchikus rendszere mentén klaszteranalízis módszerével 12 státuscsoportot különít el. ${ }^{4}$ Utasi (1984) szintén a klaszteranalízis módszerét használva alkotja meg életstíluscsoportjait. ${ }^{5}$ A rendszerváltást követően Kolosi (2000) kísérletet tesz arra, hogy tesztelje státuscsoportjainak változását. A korábbi módszeréhez hasonló eszközökkel méri a rendszerváltás után bekövetkező változásokat. Megállapítja, hogy a nyolcvanas években meghatározott státuscsoportok többsége a kilencvenes évek végére változatlan maradt, bár az egyenlőtlenségi viszonyok átrendeződésével bizonyos csoportok eltűntek vagy egymásba olvadtak. 2010-ben közzétett tanulmánya továbbfüzi eddigi társadalomszerkezeti kutatásait, és a négy különböző időpontban mért vizsgálatai alapján közel harminc év társadalomszerkezeti változásait írja le egységes módszertani elvek alapján. A tanulmány fontos megállapítása (Kolosi és Keller, 2010), hogy a kétezres években nőtt a foglalkoztatottság és a társadalmi státus ${ }^{6}$ közötti kapcsolat, illetve megnőttek a társadalmi egyenlőtlenségek.

\section{Társadalmi mobilitás, esélyegyenlőség, iskola}

A modern társadalmakban fontossá vált az az igény, hogy a társadalmi státuszt ne a család vagy születés határozza meg, hanem az egyéni teljesítmény. Az iskoláztatási esélyek egyenlősége a modern ipari társadalmak alapeszménye (Hradil, 1995). Treiman (1970) azt is megállapítja, hogy minél fejlettebb egy 
ipari társadalom, a társadalmi egyenlőtlenségi rendszerben elfoglalt helyet annál inkább az iskolai végzettség határozza meg és nem a származás. Vagyis modern ipari társadalmakban az iskola a legfőbb mobilitási csatorna.

$\mathrm{Az}$ iskoláztatási esélyeket vizsgálva már a két világháború közötti oktatáskutatók is rámutattak arra, hogy a különböző társadalmi osztályok eltérő eséllyel kerülnek be bizonyos iskolatípusokba, így pl. a munkásosztály gyermekei az iskoláskorú tanulók arányához képest jóval alacsonyabb arányban kerülnek be a gimnáziumi képzésekbe (Lawton, 1974). Amellett, hogy az oktatási rendszer nem biztosítja az egyenlő bejutás esélyét, további probléma az iskolában maradás kérdése is, mivel a munkásosztály körében magas az iskolaelhagyók aránya. Lauton arról is áttekintést ad, hogy a lemorzsolódás okai között mennyire játszik szerepet a különböző társadalmi csoportok szubkultúrája.

$\mathrm{Az}$ iskolai eredményességet kutatók az oktatási esélyek egyenlőségét a hatékonyság egyik jegyeként definiálják. A legelső ilyen irányú vizsgálatot Coleman végezte (1966). Arra a kiábrándító tényre mutatott rá, hogy az iskolának nincs számottevő hatása diákjainak eredményeire, arra sokkal inkább a szülők szocioökonómiai státusának van befolyása. Az iskolai változók a diákok eredményeinek alig tíz százalékát magyarázzák. Coleman eredményeit sokan megkérdőjelezték, különösen azért, mert kevés iskolai változót vett figyelembe vizsgálata során, de azt a tényt, hogy az Egyesült Államokban az iskolai teljesítmény társadalmi háttérhez kötött, később mások is igazolták (Jencks és mtsai, 1971).

Coleman nagyhatású vizsgálatát negyven évvel később megismételte a Wisconsini Egyetem kutatócsoportja (Gamoran és Long, 2006). Megállapítják, hogy a hatvanas években az Egyesült Államok oktatása faji és etnikai csoportok szerint erősen szegregált volt. 1954-1980 között a deszegregációs program révén csökkent az elkülönült oktatásban résztvevők aránya, ugyanakkor a kilencvenes évektől ismét emelkedésnek indult, és ez a visszarendeződés ma is tart. Az iskolai teljesítményt elemezve, a kutatók azt tapasztalták, hogy a hatvanas években a 12 . osztályos fekete diákok 85\%-ának teljesítménye a fehérek átlaga alatt volt, mára ez a különbség csökkent. Leginkább a nyolcvanas években, a deszegregációs program idején 
tudott tartósan alacsony maradni a különbség. 2004-ig csökkent a különbség a feketék és a fehérek teljesítménye között, azóta ismét emelkedik. Az új vizsgálat azt is megállapítja, hogy a hatvanas évekhez képest nem sokat változott a helyzet. Az amerikai oktatásban továbbra is jellemző az erős szegregáció és a családi hatás erős befolyása az iskolai teljesítményre.

Míg az egyenlötlenségek a társadalmi hierarchiában elfoglalt helyet fejezik ki, addig a mobilitás az ebben a hierarchiában való vertikális mozgást, amely lefelé és felfelé is irányulhat. A társadalmi mobilitás folyamatait hihetetlen sokfélesége és komplexitása miatt nehéz megragadni. (Bertaux és Thompson, 1997) A folyamat bonyolultságát mutatja, hogy nem áll rendelkezésünkre stabil értelmezési keret, hiszen rengeteg körülmény befolyásolja a mobilitást, mint például a nagy gazdasági, politikai változások, forradalmak, de egyéni vagy családi szinten is számtalan tényező, így például egy tönkrement házasság, hogy csak a legfontosabbakat említsük.

A társadalmi mobilitás fogalmának megértését segíti elő, ha a mobilitás különböző irányai felől közelítünk a témához. Intergenerációs (nemzedékek közötti) mobilitásnak nevezzük a szülők státusához képesti mozgást, míg az egyén karrierpályáján belüli mozgást intragenerációs (nemzedéken belüli) mobilitásnak. Cirkuláris mobilitásnak tekintjük, amikor csak bizonyos egyének cserélnek helyet a társadalomban. A társadalmi mozgások nagyságára és mélységére utal az egyéni és a kollektiv/ csoportos mobilitás megkülönböztetése, az egyéni mobilitás gyakorlatilag érintetlenül hagyja a kialakult társadalmi viszonyokat, míg a kollektív mobilitás folyamatosan átalakítja azt. Vagyis, ha egy társadalomban elő is fordul egyéni mobilitás, attól még konzerválódhatnak a társadalmi viszonyok, mivel az olyan jelentéktelen mértékű, hogy nem bontja meg a társadalom szerkezetét. Nagyobb társadalomszerkezeti változások idején (pl. rendszerváltás) strukturális mobilitásról beszélünk. Míg egyes irányzatok a (gazdaság) foglalkozásszerkezeti változásain keresztül vizsgálták a társadalmi mobilitást, addig mások főként a politikai berendezkedés társadalmi mobilitásra tett hatásait elemezték. (Róbert, 1986, 1991, 1998)

Lipset és Bendix (1991) azt a kérdést is felvetette, hogy vajon a mobilitásnak milyen fokmérői lehetnek, mihez viszonyít- 
sunk. A társadalmi mobilitást idődimenzióban vagy összehasonlításban érdemes elemezni, vagyis egy adott társadalmat vagy valamely korábbi időszakaihoz, vagy más országokhoz képest lehet megítélni. Emellett a szerzők egy harmadik lehetőséget is megemlítenek, az egyenlő lehetőségek modelljét, amelyben nem is a mobilitás arányai az érdekesek, hanem az, hogy mennyire egyenlőtlenek az ahhoz az úthoz vezető lehetőségek. Az iskola világa, az oktatás szempontjából számunkra ez a harmadik elemzési lehetőség a legfontosabb, mivel a tanulási utak alakulásában éppen ezeket az egyenlő/egyenlőtlen lehetőségeket mutatjuk majd be.

A társadalmi mobilitás kutatásának atyja, Sorokin véleménye szerint a vertikális mobilitás minden társadalomban jelen van, melynek több intézményes eszköze is lehet. Az egyház és a hadsereg mellett Sorokin az iskolát tartja a társadalmi mobilitás egyik legfontosabb intézményének (Sorokin, 1998). Megállapítása szerint az iskola liftként szállítja az utasait, vannak olyan társadalmak, ahol ez a lift legalulról indul, míg akadnak olyanok is, amelyekben csak közbülső emeletekről lehet feljebb jutni, és a legalsó társadalmi rétegek előtt bezárul. Sorokin kiemeli, hogy az iskola nem csak oktatási intézmény, hanem a társadalmi pozíció kiválasztására is szolgál. A versenyek, vizsgák, rangsorok, minősítések és buktatások arra szolgálnak, hogy szelektálják és elosszák az egyéneket majdani társadalmi pozícióikba. Sorokin szerint, az az egyén, akit az iskola szűrője kirostál, már kevés eséllyel találhat más mobilitási csatornát a feljebb jutásra. A különböző történelmi korszakokban múködhettek olyan önszelekciós mechanizmusok is, melynek révén az egyén már el sem jutott az iskolába. Minél szélesebb tömegek számára tárja ki az iskola a kapuit, annál inkább érvényesíti szelekciós mechanizmusait. Minél nagyobb egy szinten az iskolai expanzió, annál magasabb szintre tolódik a szelekciós mechanizmus. (Mare, 1981)

Mobilitáskutatók szerint stabil társadalmakban az intergenerációs mobilitás gyakoribb, mint az intragenerációs. Ez utóbbi mobilitási forma főként az iskoláztatás következménye, vagyis az egyén leginkább pályája elején kerül magasabb osztályhelyzetbe és csak ritkábban szakmai előmenetele révén. (Lopraeto és Hazelrigg, 1998) Az iskola és a foglalkoztatási 
státus összekapcsolódásának klasszikus példája Japán, ahol az egyes iskolafokok alapvetően meghatározzák az egyén későbbi foglalkozási hovatartozását. Az újabb kutatások azt is vizsgálják, hogy vajon az egyén számára mekkora jövedelemi eltérést okoz a munkapiacon, ha iskolázottsági szintje eltér foglalkozási státusától (Nordin és mtsai, 2010).

Kutatók azt is megállapítják, hogy míg az intergenerációs mobilitás mintázatai országok közötti összehasonlítása stabilan mérhető, addig az intragenerációs mobilitás kevésbé összevethető. Ez főként az országonként változó foglalkozási szabályozással magyarázható (milyen végzettséggel milyen munkakört lehet ellátni). Így az intragenerációs mobilitásban fontos szerep jut az adott ország oktatási rendszerét jellemzői tényezőknek. Minél specializáltabb képzést nyújt az iskolarendszer, annál szorosabb lesz a kapcsolat a végzettség és az osztályhelyzet között, illetve az iskolai végzettség és a foglalkozás között. (Kurz és Müller, 1998) Németországban például a tanoncképzés miatt inkább érvényesül a képzettségen alapuló mobilitás, mint például a szomszédos Franciaországban, ahol a szakmai képzés a közoktatási rendszeren kívül zajlik (Müller és Shavit, 1998; Dronkers, 2010). A végzettségek és a foglalkozások kapcsolatának intenzitása időben is változhat, így például a magyar oktatási rendszer a rendszerváltás előtt inkább a némethez volt hasonlatos, majd egyre inkább az általános képzés térhódítása volt megfigyelhető, míg az új évezred első évtizedének végén ismét a specializálódás irányába indult el.

Ganzeboom, Treiman és Ultee (1998) három generáción keresztül vizsgálták a társadalmi mobilitást. Következtetéseik között fontos megállapítás, hogy a szülői foglalkozásnál az iskolai végzettség hatása erősebb a foglalkozási státusra, és az iskolázottság hatásának foka független a származástól, viszont az oktatás fontos eszköze az előnyök átörökítésének. A származás és az iskolázottság kutatásához kötődik Treiman elmélete (1970) is. Véleménye szerint a modernizációs folyamatok, a gazdasági-technikai fejlődés és az oktatás expanziója nyitottabb társadalomhoz vezet. Treiman később empirikusan tesztelte hipotézisét (1989), és igazolta is azt, mivel 21 ország összehasonlító vizsgálta alapján megállapította, hogy az ipa- 
rosodott országokban az egyén foglalkozását az iskolázottsága jobban befolyásolja, mint a származása.

Az újabb mobilitásvizsgálatok a jövedelemegyenlőtlenségek alapján elemzik a mobilitást, és már a fogalmat is leszúkítik ezzel, hiszen nem társadalmi, hanem gazdasági mobilitást vizsgálnak. Aaronson és mtsai (2008) a különböző cenzusok nagymintás adatai alapján elemzi az amerikai társadalom hatvan évének mobilitási adatait, 1940 és 2000 között. Ebben a vizsgálatban az oktatás is kiemelt szerepet játszik. A szerző megállapítja, hogy a nyolcvanas évek után az oktatásnak nagyobb a hatása az intergenerációs mobilitási rugalmasságra, mint előtte. Az intergenerációs mobilitás időben szorosan nyomon követi az egyenlőtlenségi trendeket. Ennek valószínű oka az oktatás változó befolyása. Az oktatás csak egy részét magyarázza az intergenerációs mobilitásnak, emellett még számos más tényező van, melyek feltárása további kutatást igényel.

Szintén a jövedelemegyenlőtlenségekre alapozva készült egy kutatás, amely az Egyesült Államok társadalmi mobilitási folyamatait vizsgálja. Az elemzés alapját a személyijövedelemadó-bevallások képezik. Chetty, Hendren, Kline és Saez (2014) minden 1980 és 1982 között az országban született gyerek jövedelmi helyzetét (az adóbevallások alapján) megvizsgálta születése pillanatában, illetve napjainkban. Az értékek öszszevetése megmutatta, hogy harminc év alatt hová jutottak. A kutatás eredménye sokkolta az amerikai közvéleményt, mivel a vagyoni eloszlások alapján a nyolcvanas években a társadalom alsó ötödébe megszülető gyerekek csupán nyolc százaléka volt képes arra, hogy felnőtt korára a legfelső ötödbe kerüljön. A középső ötödbe született gyerekeknek pedig húsz százaléka volt képes feljutni a felső ötödbe. A kutatók azt is vizsgálták, hogy milyen változóknak van hatása a mobilitásra. Arra a következtetésre jutottak, hogy öt faktor hatása a legjelentősebb: területi/lakóhelyi szegregáció, vagyoni egyenlőtlenség, családszerkezet, társadalmi tőke (közösségi, civil élet szervezettsége) és az iskolarendszer. Ez utóbbival kapcsolatban azt mutatták ki, hogy ahol magasabbak az iskolai tesztpontszámok ${ }^{7}$, illetve kisebb a lemorzsolódás, ott nagyobb a mobilitás. Az is fontos megállapításuk, hogy mely tényezőknek nincs hatása a társadalmi mobilitásra. 
Európában is készült egy átfogó mobilitásvizsgálat, amely 1970-2000 között 11 ország társadalmi mobilitását hasonlította össze. Breen (2004) 117 mobilitáskutatás (cenzus, háztartáspanel, egyéb survey jellegű vizsgálatok) adatait használta fel, összegezte, és összehasonlította az egyes országok intergenerációs mobilitását a vizsgált három évtizedben. A kutatás nemcsak az egyes országokat hasonlítja össze nyitottságuk (mekkora a mobilitási lehetőség) alapján, hanem egyes országok idősoros adatait is. ${ }^{8}$ Kiemeli, hogy az egyenlőtlenségek nem csökkentek a vizsgált időintervallumban, az iskolázottság továbbra is fontos mobilitási csatornát jelent valamennyi európai társadalomban, valamint, hogy az oktatáshoz való hozzáférési esélyek erőteljesen függnek a társadalmi háttértől. Az adatok alapján a felmérésben részt vevő országokat is igyekezett összehasonlítani. Arra a következtetésre jutott, hogy Franciaország, Olaszország és Németország inkább a rigid, míg az északi államok inkább a nyitottabb országok közé tartozik. Magyarország is ez utóbbi csoportba sorolható. Ugyanakkor akadnak olyan országok is, amelyek a vizsgálat időintervalluma alatt változást mutattattak, így például a holland társadalom fokozatosan nyitottá vált az évek során.

Breen és Jonsson (2005) feltárták az összes olyan korábbi mobilitáskutatást, amelyben az oktatás valamilyen formában szerepet játszott. Azt tapasztalták, hogy ezekben a vizsgálatokban két területre fókuszálnak a kutatók: a származás iskolai végzettségre tett hatására, valamint a származás és a foglalkoztatásban betöltött szerep kapcsolatára. Megállapítják, hogy a kutatások egy része a származás iskolai végzettségre tett hatását olyan változókkal mérte, mint a szülő iskolázottsága, motivációi, más szóval a szülő szocioökonómiai státusát elemezték, ugyanakkor van egy másik elemzési eszköz is, a racionális választás modellje. Ez utóbbi arról szól, hogy vajon az oktatási döntéseket (iskolaválasztást, iskolai utat) milyen tényezők befolyásolják. Mi alapján mérlegel a tanuló és a családja a különböző oktatási utak sikerességének megítélésekor? Breen úgy látja, hogy manapság a mobilitáskutatásokban az az irány éled újjá, amelyek az egyéni viselkedést, választásokat, döntéseket vizsgálja. A racionális cselekvéselméleti modell Boudon (1974) nevéhez köthető, aki szerint az iskolaválasztásban a családi háttér kettős hatása érvé- 
nyesül. Az elsődleges hatást a kulturális tőke átörökítése jelenti, míg a másodlagos akkor érvényesül, amikor a lehetséges tanulói utak közül a gyerek számára a legmegfelelőbbet választják ki.

Lucas (2001) kritizálja ezt a vizsgálati módszert. Az ő elemzése a tanulói utakat és az iskolai átmeneteket célozza meg. Empirikus eredményei azt igazolják, hogy a családi háttér szerepe fontos az egyéni célok elérésében és az egyenlőtlenségek hatékony fenntartásában, ugyanakkor a döntési modellek vizsgálata helyett a tanulói utakat és az iskolai átmeneteket elemzi. Azzal érvel, hogy habár az USA-ban általánossá vált a középiskolában való továbbtanulás (tehát a választásokban, döntésekben nincs jelentős különbség), a tanulói utak mégis nagyfokú lemorzsolódást mutatnak, és a lemorzsolódás egyértelműen társadalmiháttér-függő. Ennek értelmében az oktatási expanzió önmagában nem csökkenti az egyenlőtlenségeket. Ugyanerre a megállapításra jutott Reay (2006) is az angol oktatást vizsgálva. Azt tapasztalta, hogy az oktatási különbségek növekednek a szegény és a gazdag gyerekek között. Amíg alapfokon a különbség a legrosszabb és a legjobb tanuló között szúkült, addig a deprivált és a gazdag gyerekek között növekedett az elmúlt 6 évben. A brit mobilitáskutatások azt mutatják, hogy a mai középosztálybeli tanulók 16 éves kor után ötven százalékkal többen maradnak benn az oktatásban munkásosztálybeli társaikhoz képest.

\section{Társadalmi mobilitás és jövedelmi egyenlőtlenségek}

Ez a két téma a kutatásokban gyakran összekapcsolódik. A kutatók legtöbbször arra a következtetésre jutnak, hogy amelyik társadalomban növekednek az egyenlötlenségek, ott a felfelé irányuló mobilitás beszúkül.

Manapság az egyik legnépszerübb jövedelmi egyenlőtlenség mérésére alkalmas index, a Gini-index, amely a jövedelem és a vagyon statisztikai eloszlásainak egyenlőtlenségeit méri. Nevét Corrado Gini olasz közgazdászról kapta. A Gini-index bármely értéket felvehet 0 és 1 között; sokszor azonban százalékos skálára számítják át. Minél nagyobb az egyenlőtlenség, annál nagyobb az index értéke (Nemes-Nagy, 2009). Az inde- 
xet több szupraszervezet is méri, így az OECD vagy a Világbank. Adataik szerint az elmúlt évtizedben nőttek az egyenlőtlenségek az egész világon (Milanovic, 2009; Ferreira és Ravallion, 2009). Arra is rámutatnak, hogy az abszolút szegénység inkább a fejlődő országok problémája, mint a fejletteké, illetve hogy negatív korreláció mutatkozik az egyenlőtlenség átlagos szintje és a fejlettség szintje között. Európai összehasonlításban a magyar adatok nem mutatnak kirívó értéket, sem a legegyenlőtlenebb (Litvánia, Románia, Bulgária), sem a legegyenlőbb (Szlovénia, Szlovákia, Svédország) országok közé nem tartozunk, bár inkább az egyenlőbb alsó harmadában vagyunk, így globális szinten is inkább az egyenlőbb országok sorát gyarapítjuk. (Balázs és Mártonfi, 2011; Medgyesi, 2010) Miles Corak (2013) amerikai közgazdász pozitív összefüggést talált az egyenlőtlenségek (Gini-index) és a társadalmi mobilitás, vagyis immobilitás között, ebből alkotta meg a Nagy Gatsbygörbét ${ }^{9}$. A görbe azt mutatja, hogy minél alacsonyabbak az egyenlőtlenségek, annál alacsonyabb a nemzedékek közötti immobilitás. Corak 13 országot ${ }^{10}$ vizsgált meg ily módon, és azt tapasztalta, hogy míg az észak-európai országokat kicsi egyenlőtlenség és alacsony immobilitás jellemzi, addig az Egyesült Államokat, Angliát és Olaszországot a legnagyobb mértékű.

Wilkinson és Pickett (2009) az egyenlőtlenségek vizsgálatában a társadalom egészségügyi, szociális problémáit kapcsolta össze. Megállapítják, hogy a jövedelmi egyenlőtlenségek szoros kapcsolatot mutatnak a várható élettartammal, a csecsemőhalandósággal, a gyilkosságok számával, a bebörtönzés mértékével, a tinédzserkori szülések nagyságával, a társadalom bizalmi indexével, az elhízottság mértékével, a különböző mentális betegségekkel és nem utolsó sorban az iskolai szövegértés- és a matematika-teszteredményekkel, valamint a társadalmi mobilitással. A felsorolt elemeket önállóan is vizsgálták, illetve ezekből egy közös indexet is létrehoztak. A korrelációs értékek az egyenlőtlenségek és a mobilitás között a legnagyobbak. Azokban az országokban, ahol nagyok a jövedelmi egyenlőtlenségek, kisebb a társadalmi mobilitás esélye. Megállapítják, hogy az észak-európai országokban nagyok a mobilitási esélyek (Finnország, Dánia, Svédország), míg a skála másik végén az Egyesült Államok és Nagy-Britannia áll. 


\section{Hazai kutatók: egyenlőtlenségek, mobilitás és iskola}

Az egyenlőtlenségek és iskola kapcsolatával foglalkozó kutatást Magyarországon először Ferge Zsuzsa (1980) végzett 1972-ben. Megállapítja, hogy a tanulmányi eredményekben erősen kimutatható a társadalmi meghatározottság, továbbá hogy az általános iskolai évek alatt a hátránnyal induló gyerekek hátránya tovább növekszik. Az elsődleges szelekciós rendszert felerősíti egy másodlagos szelekció is: az iskola képességek szerint homogenizálja a tanulókat. Ferge szerint ebből adódik a hátrányok növekedése az amúgy is hátrányos helyzettel induló csoportok számára. Kozma (1975) könyvében az egyenlőtlenségek tanulói szempontú megközelítése mellett az iskolai hátrányokat is elemzi, bemutatva, hogy az eredménybeli különbségeket az iskolák közötti különbségek is okozzák (pl. ellátottság, pedagógusok felkészültsége).

A hetvenes években már számos olyan tanulmány született, amely megerősítette azt, hogy az iskola nem képes leküzdeni a társadalmi egyenlőtlenségeket, sőt szelekciós mechanizmusai révén (tagozatos osztályok, kisegítő osztályok) a kedvezőbb helyzetben lévő társadalmi csoportok érdekeiket érvényesíti (Gazsó, 1979; Róbert, 1986, 1991; Andor, 2001).

A rendszerváltást követően - bár számos mélyreható változás történt az oktatásban - a kutatások mégis azt bizonyítják, hogy a magyar iskolarendszer újratermeli az egyenlőtlenségeket (Berényi és mtsai, 2008; Andor, 2001; Liskó és Fehérvári 1996, 1998; Fehérvári, 1996). Gazsó és Laki (1999) szerint, bár a szocializmus időszaka után nagy társadalmi változások zajlottak le, mégis újratermelődnek bizonyos egyenlőtlenségek, melyek leginkább a fiatalokat sújtják az iskolázás, szakmaszerzés és munkába állás területein. Gazsó is arra a megállapításra jut, hogy az iskola nem tud segítséget nyújtani azoknak, akik tanulását hátrányok nehezítik.

A tanulói teljesítmény és a családi háttér kapcsolatát vizsgálják a nemzetközi (PISA, PIRLS, TIMSS) és a hazai (korábban Monitoring, ma Országos kompetenciamérés) mérések is. Ezekből a mérésekből kiviláglik, hogy Magyarországon különösen erős az iskolai teljesítmény és a családi háttér közötti 
összefüggés (PISA 2012..., 2013; Balázsi és Horváth, 2011). További aggasztó tény, hogy az iskola nem csökkenti, hanem növeli a családi háttérből fakadó különbségeket, és az iskolaválasztás (az iskolák közötti különbségek), a képzési program kiválasztása erősen determinálja az egyén későbbi életútját.

A magyar kutatási irányok követték a nemzetközi trendeket mind a jövedelemegyenlőtlenségek, mind a mobilitáskutatások területén. Magyarországon is történtek kísérletek a jövedelemegyenlőtlenségek elemzésére, bár kevésbé voltak olyan nagyszabású vizsgálatok, mint a fentebb bemutatott amerikai kutatások. A fejlett országokra vonatkozó vizsgálatok azt mutatták ki, hogy sok országban, így pl. az Egyesült Államokban is nőttek a jövedelemkülönbségek, a gazdagok még gazdagabbak lettek, a szegények pedig még szegényebbek. Ugyanezek a tendenciák figyelhetők meg Magyarországon is. A magyar helyzetről a háztartáspanel-vizsgálatok, illetve a személyijövedelemadó-bevallások szolgáltatnak adatokat. Módszertanilag mindkettő korlátozott mértékben hasznosítható. Míg az előbbi vizsgálatból leggyakrabban a legszegényebb és a leggazdagabb családok maradnak ki (a válaszmegtagadók aránya itt a legmagasabb), addig az adóbevallások sem fedik le a teljes spektrumot, gondoljunk csak a szürke vagy fekete gazdaságra. Kovács (2011) 1996-2009 közötti időszakra vonatkozóan vizsgálta a jövedelmi eloszlásokat az adóbevallások alapján. Elemzése azt mutatja, hogy az elmúlt 20 évben Magyarországon is növekedtek a jövedelemegyenlőtlenségek, és a jövedelmek koncentrációjával párhuzamosan növekedett az elszegényedés. Ugyanezt az eredményt mutatják a háztartáspanel-vizsgálatok adatai is, amelyek főként a szegénység növekedését jelzik (Tóth, 2010).

A magyar mobilitásvizsgálatok közül a hatvanas-hetvenes években Andorka Rudolf, míg a nyolcvanas évektől napjainkig Róbert Péter vizsgálatait emelhetjük ki. Kutatási eredmények szerint a magyar társadalomban a hetvenes évekhez képest a nyolcvanas években a nemzedékek közötti mobilitás lelassult, a kilencvenes évekre pedig már csökkenés figyelhető meg (Bukodi, 2001; Róbert és Bukodi, 2004; Róbert 1986, 1991). Az elemzések arra is rámutattak, hogy a klasszikus vertikális mobilitásirányok elemzésének értelmezésében fontos szere- 
pet játszanak a külső hatások/kényszerek és az egyén szándékainak elkülönítése is (Kolosi és Róbert, 2004).

A mobilitáskutatások közül kiemelhető még Németh (2006) vizsgálata, aki 1983-as, 1992-es, 2000-es adatfelvételeken keresztül elemezte a mobilitás változását és annak hátterét, azt, hogy az iskolázottság vagy a származás hat erősebben a mobilitásra. Azt tapasztalta, hogy a vizsgált időperiódusban az iskolai végzettség lényeges szerepet játszik az egyén státuselérésében, ugyanakkor nem változott e hatás erőssége az évek során. A származás (az apa foglalkozása) ugyancsak erős hatást gyakorol az iskolázottságra. Nem igazolódott be azonban az a treimani feltételezés, hogy az iskolázottság származástól függetlenül mozog, vagyis Magyarországon az iskolázottságot a származás jelentősen befolyásolja.

A magyar mobilitásvizsgálatokban is kiemelt szerepet kapott az oktatás, a származás kontra iskolai végzettség mobilitási hatásainak elemzése. Míg a hetvenes-nyolcvanas években a középfokú oktatás expanziója, addig a kilencvenes és a kétezres években a felsőoktatás expanziója vetette fel azt a kérdést, hogy az expanzió önmagában növeli-e a mobilitási esélyeket. Andorka és Simkus (1983) úgy találta, hogy az egységes alapfokú képzés származástól függetlenül, önmagában növelte az esélyegyenlőséget. Úgy vélték, hogy nem az a folyamat következett be Magyarországon, mint az USA-ban vagy Angliában, ahol egyszerűen az egyenlőtlenségek egy oktatási szinttel feljebb tolódtak. A felsőoktatás expanziója kapcsán született vizsgálatok azt mutatták ki, hogy az expanzió révén alacsonyabb státusú társadalmi csoportok is bekerülnek a felsőoktatásba (Székelyi és mtsai, 1998). Más kutatások viszont azt bizonyították, hogy már a középfokú oktatásban is jelentős szelekciós, illetve önszelekciós mechanizmus érvényesül (Liskó és Fehérvári, 1998; Róbert, 2000, 2010; Nagy, 2010). Emellett más elemzések arra is rámutattak, hogy a képzésbe való bekerülés még nem jelenti a magasabb iskolai végzettség megszerzését (Gazsó, 2004), így az expanziónak önmagában nincs esélykiegyenlítő hatása.

Andor és Liskó (2000) azt vizsgálta, hogy az iskolaválasztás milyen mobilitási sajátosságokat mutat. Megállapítják, hogy az iskolaválasztást jelentősen determinálja a szülő iskolázott- 
sága. Az alacsonyan iskolázott szülők gyermekeinek fele szakiskolában tanul tovább, a másik felének döntő többsége pedig szakközépiskolában. Ugyanakkor a magasan iskolázott szülők gyermekei szinte kivétel nélkül érettségit adó képzésben tanulnak tovább, azon belül is a gimnáziumi képzést preferálják.

Sági (2003) a racionális cselekvéselméleti modellt (Boudon, 1974) alkalmazta a hazai iskolaválasztás-vizsgálatában. Az 1997-es szülői és tanulói vizsgálat azt mutatta, hogy a szülők döntő többsége legalább olyan foglalkozási státust képzelt el gyermekének, mint saját magának, illetve általában egylépcsős mobilitással számoltak. A gyermekek hasonlóan gondolkodnak, az általuk vágyott foglalkozási státus a szülői tervekhez hasonlatos. A szerző azt is kiemeli, hogy a vágyott foglalkozási csoport és a vágyott középiskola között szoros a kapcsolat, viszont a vágyott és a valószínú iskolaválasztás között nagy a különbség.

\section{Az Arany János Program}

A felsőoktatás tömegesedésétől sokan azt várták, hogy ezzel minden társadalmi csoport számára egyaránt növekednek majd a bejutási esélyek. Egy 1998-ban végzett átfogó vizsgálat egy teljes érettségiző korosztály átmenetét vizsgálta a középfokról a felsőoktatásba (Csákó és mtsai, 1998). A teljes körű adatfelvételben valamennyi szakközépiskolás és gimnazista önkitöltős kérdőívet töltött ki még az érettségi vizsga előtt, melyben családi hátterüket, iskolai útjukat, továbbtanulási ambíciójukat vizsgálták a kutatók. A kutatás második fázisában a kérdőíves adatokat összekapcsolták a felsőfokú felvételi eredményekkel. Így pontos kép rajzolódott ki arról, hogy kik azok, akik bekerülnek a felsőoktatásba. A vizsgálat egyik fontos megállapítása volt, hogy a szelekció már korábban, a középfokra lépésnél megtörténik. A gimnáziumi képzésből nagyobb eséllyel kerülnek be a diákok a felsőoktatásba. A kutatás azt is kimutatta, hogy a kistelepülésen élők bekerülési esélyei jóval alacsonyabbak városi társaikéhoz képest.

Alapvetően ezek a tények ösztönözték az akkori oktatáspolitikát az Arany János Program elindítására. A program a kistele- 
pülésen élő tehetséges, hátrányos helyzetű tanulók felsőoktatási esélyeit azzal kívánta növelni, hogy kiemelkedően teljesítő középiskolákba juttatja be őket. Az Arany János Tehetséggondozó Program indulásakor a döntéshozók elsősorban a települési hátrányokkal küzdő tanulók támogatását tartották fontosnak. Később a program célcsoportja kibővült, a kistelepülési hátrány mellett más (szociális) hátrányokat is figyelembe vettek. A program célja a tehetséges gyermekek továbbtanulásának elősegítése, felsőfokra juttatása, emellett korszerü, munkapiacon fontos ismeretek nyújtása, mint informatika (ECDL vizsga), idegen nyelv (nyelvvizsga) és autóvezetés (jogosítvány).

A 2000-ben induló tehetséggondozó program 2004-ben a kollégiumi, 2007-ben pedig a kollégiumi szakiskolai programmal bővült. Azóta is ez a három program képezi az Arany János Programokat. A később induló kollégiumi és kollégiumi szakiskolai programok célja hasonlóan alakult: a kollégiumi program esetében az érettségi, míg a kollégiumi szakiskolai program esetében a szakmaszerzés a cél. Vagyis mindhárom alprogram iskoláztatási támogatást nyújt hátrányos helyzetű csoportok számára, lehetőséget adva a csoportos társadalmi mobilitásra ${ }^{11}$.

Magyarországon kevés olyan oktatási program van, amely évtizedes múlttal rendelkezik, ezek között van az Arany János Program. Nem véletlen, hogy a legtöbb hatásvizsgálat, programértékelés ehhez a programhoz kapcsolódik. A kutatások elemezték a bekerülési esélyeket, a program célcsoportjait és azt is, hogy vajon e program nélkül mi történt volna a tanulókkal (Fehérvári, 2008). Megállapították, hogy a program nélkül ezek a diákok nem jutottak volna be a továbbtanulási esélyt adó elit gimnáziumokba, valószínű a szakképzésben folytatták volna tanulmányaikat.

A program eredményességére is vonatkoztak mérések. Az Országos kompetenciamérés 2009-es adatsoraiban beazonosításra kerültek a tehetséggondozó program részt vevői. A 10. évfolyamos mérés azt mutatta, hogy a programban részt vevők mindkét területen, matematikából (560 pont) és szövegértésből (574 pont) is jobban teljesítettek, mint az országos átlag (489 és 496 pont). Ez a teljesítmény elmarad ugyan a 6 és 8 évfolyamos gimnáziumok tanulóinak eredményeitől, de meghaladja a 4 évfolyamos gimnáziumok átlagpontszámát 
matematikából és szövegértésből is. A 4 évfolyamos gimnáziumba járókkal összehasonlítva azt tapasztaljuk, hogy a tehetséggondozó programra járó tanulók körében az első alatti és az első képességszinten álló tanulók aránya jóval kevesebb. Ugyanakkor a legkiválóbb szinten már nincs ilyen eltérés, sőt a 4 évfolyamos gimnazisták között némileg magasabbak az ide tartozók aránya (Fehérvári és Széll, 2014).

Egy 2013-as vizsgálat szintén a tanulói teljesítmény kutatta, az iskolai teljesítményt befolyásoló pszichológiai sajátosságokat igyekezett felmérni, melynek célcsoportját a program tanulói képezték. Az elemzés megállapítja, hogy a hátrányos helyzetű tehetséges tanulók esetében a képességeik jelentik a tanulmányi eredményességük legfóbb fedezetét (Pásku, 2013). Ugyanakkor ez csak abban az esetben jelent a hozadékot, ha összekapcsolódik az érdeklődésükkel is.

E vizsgálatok alapján megállapítható, hogy az Arany János Program sikeres kísérlet, amely megmutatta, hogy az erősen szelektív és a társadalmi esélyegyenlőséget nem támogató iskolarendszerben is lehetséges az esélyteremtés egy néhány ezer főt számláló csoport számára. A tanulók átestek egy a családi szocializációtól eltérő szocializáción, és olyan ismeretekkel vérteződtek fel, melyek jobb esélyt biztosítanak pályájukon és a munkapiacon. Emellett a középiskolák és a kollégiumok tanárainak szemlélete is megváltozott: egyrészt a hátrányos helyzetű gyerekekről alkotott véleményük pozitívabbá vált, másrészt pedagógiai kultúrájuk is gazdagodott, melyet már nemcsak a hátrányos helyzetű tanulók oktatása során kamatoztatnak (Fehérvári, 2013).

\section{Összegzés}

A társadalmi egyenlőtlenségek és a mobilitás nevelésszociológiai kutatási irányai közül főként azokat emeltük ki, amelyek az iskola, az oktatás szerepével is behatóbban foglalkoznak. A társadalmi egyenlőtlenségek a társadalmi hierarchiában elfoglalt pozíciók közötti távolságot jelenítik meg, míg a társadalmi mobilitás e pozíciók közötti mozgás. Mind az egyenlőtlenségek, mind a mobilitás megítélése viszonyítás kérdése, nincsenek 
abszolút mérőszámai, általában egy adott társadalmon belül értelmezhetők időben és térben. Az egyenlőtlenség össze is kapcsolódik a mobilitással (egyenlőtlenségek nélkül mobilitás sem lenne), hiszen a hozzáférési esély egyenlő vagy egyenlőtlen volta hat a mobilitási esélyekre is.

A modernkori társadalom egyenlőtlenségi viszonyrendszerében elfoglalt hely alakulását az oktatás és a származás egyaránt befolyásolja. Minél fejlettebb egy társadalom, a származással szemben inkább az iskolai végzettség határozza meg a társadalmi egyenlőtlenségi rendszerben elfoglalt helyet, mert annál inkább képes az egyéni teljesítmény alapján szelektálni, hatékonyan kihasználva az egyén felkészültségét, tehetségét. Ennek megfelelően az iskola a társadalom legfontosabb mobilitási csatornája. A kérdés csak az, hogy mindenki számára azonos-e az iskolához való hozzáférés esélye. Társadalmanként és időszakonként is változik a válasz, ugyanakkor nincs olyan társadalom, amelyben bárki számára is egyformák lennének az esélyek.

Törvényszerű, hogy minél szélesebb tömegek számára tárja ki az iskola a kapuit, annál inkább előtérbe kerül az iskolarendszeren belüli szelekció, s egy képzési szinten minél nagyobb az expanzió, annál magasabb szintre tolódik a szelekciós mechanizmus. Ugyanakkor az már kevésbé törvényszerü, hogy az expanzió minden társadalmi réteg számára együtt jár a hozzáférés esélyeinek növekedésével. Vannak olyan társadalmak, ahol empirikusan is igazolták ezt a tényt, és olyanok is akadtak, ahol cáfolták.

Azokban az országokban, ahol nem igazolták teljes mértékben az oktatási expanzió esélynövelő szerepét, általában erősebben befolyásolja a családi háttér a tanulói utat és a teljesítményt. A bekerülési esélyek ugyan ott is növekedtek, de emellett nagyfokú lemorzsolódást is megfigyeltek, amely leginkább társadalmiháttér-függő volt. Így az expanzió mégsem vezetett a magasabb végzettség eléréséhez.

Magyarország is azon országok közé sorolható, ahol a szülői háttérnek számottevő a befolyása a tanulói teljesítményre. A magyar oktatási rendszer további jellegzetessége: a szelektivitás és a differenciáltság. Ez azt jelenti, hogy az iskolák közötti tanulói teljesítménykülönbségek nagyobbak, mint az iskolán belüliek, valamint korán szétválnak a tanulói utak, melyek igen sokfélék. 
Ezek a sajátosságok nem mai keletűek, gyökerei már a szocializmus időszakában is látens vagy kevésbé látens módon jelen voltak, a rendszerváltás követően viszont még inkább kikristályosodtak és láthatóvá váltak.

A képzési utak egyre diverzifikáltabbá, vertikálisan tagoltabbá váltak, és társadalmi háttér szerint rendeződtek. Mivel a tanulói teljesítményt a társadalmi háttér befolyásolja, így ez a rendező elv egyben a képzési programokat is hierarchiába rendezte az eltérő tanulói teljesítmények alapján. Ebben a rendszerben az egyes tanulói utak eltérő esélyekkel járhatók, a belépési esélyek társadalmiháttér-függők.

Kutatási eredményeink szerint a társadalmi hierarchia alsóbb rétegei a rendszerváltás óta újratermelődnek, az egyéni mobilitási esélyeik szinte változatlanok. Csoportos mobilitási lehetőséget a kilencvenes években kevésbé, míg a kétezres években kevesek számára kínált az oktatási rendszer. Ezek a csatornák a képzés azon szintjein jelentek meg, ahol már erősebb szelekciós hatás érvényesül (középfokú, felsőfokú képzés). Ezek a lehetőségek akkor eredményesebbek, ha egyéni tanulói támogatással is párosulnak. Egyébként ugyanaz a mechanizmus érvényesül, mint amit már az expanzió esetében megfigyeltünk, a megnövekedett bekerülési esély még nem jelenti a végzettség megszerzését. Vagyis ezeknek a csatornáknak is a legnagyobb kockázatát a lemorzsolódás jelenti.

\section{Jegyzetek}

1 1. vezető és értelmiségi 2. középszintű szellemi 3. irodai 4. szakmunkás 5 . betanított munkás 6 . segédmunkás 7 . mezőgazdasági fizikai

2 1. felsővezetők és magas állami hivatalnokok 2. középvezetők 3. értelmiségiek 4. középhivatalnokok 5. kishivatalnokok 6. irodai alkalmazott 7. szakmunkás 8 . betanított munkás 9. segédmunkás 10. mezőgazdasági munkás

3 Kolosi hat dimenziót különít el: foglalkozás, iskolázottság, jövedelem, hatalom-érdekérvényesítés, anyagi-materiális életstílus, kulturális életstílus.

4 1. elit 2. városias felső 3 . falusias felső 4 . falusias jómódú 
munkás 5. városias jómódú munkás 6. városias középréteg 7. jó érdekérvényesítő közép 8. érdekérvényesítő alsó 9. jó anyagi helyzetű falusias alsó 10 . városias alsó 11. enyhén depriváltak 12 . deprivált csoportok

5 1. elit 2. intellektuális orientációjú 3. mintakövető 4. családorientált 5. tárgyorientált 6. emberi kapcsolatokban gazdag 7. emberi kapcsolatokban szegény 8. második gazdaságban kompenzáló 9. robotoló 10. deprivált

6 Vagyoni helyzet, lakáskörülmények, jövedelem.

7 Az USA-ban 1969 óta létezik a NAEP teszt (National Assessment of Educational Progress), amely a tanulók teljesítményét méri különböző tantárgyi területeken.

8 A könyv tartalmaz egy magyar elemzést is: Péter Róbert and Erzsébet Bukodi: Changes in Intergenerational Class Mobility in Hungary 1973-2000.

9 Az elnevezés ironikus, hiszen Scott Fitzgerald könyvében Gatsby egy reménytelenül szerelmes, szeszcsempészetből meggazdagodó figura volt.

10 Finnország, Norvégia, Dánia, Svédország, Németország, Új-Zéland, Kanada, Japán, Ausztrália, Franciaország, Olaszország, Anglia, Egyesült Államok.

11 Az AJTP 23 iskola és kollégium, valamint 13 önálló kollégium, az AJKP 11 iskola és kollégium, valamint 4 önálló kollégium, az AJKPSZ 7 kollégium, valamint 15 iskola és kollégium bevonásával múködik.

\section{Irodalomjegyzék}

Andor Mihály és Liskó Ilona (2000): Iskolaválasztás és mobilitás. Iskolakultúra, Budapest.

Andor Mihály (2001): Társadalmi egyenlőtlenség és iskola, Educatio, 1, 15-30.

Andorka Rudolf és Simkus András (1983): Az iskolai végzettség és a szülői család társadalmi helyzete. Statisztikai Szemle, 6, 592-611.

Andorka Rudolf (1982): A társadalmi mobilitás változásai Magyarországon. Gondolat Kiadó, Budapest.

Andorka Rudolf (1995): A magyar társadalom szerkezete, ré- 
tegződése és mobilitása az 1930-as évektől napjainkig. In: Valuch T. (szerk.) Hatalom és társadalom a XX. századi magyar történelemben. Budapest, 46-63.

Angelusz Róbert (2000): A láthatóság görbe tükrei. Társadalomoptikai tanulmányok. Új Mandátum Kiadó, Budapest, 39-58.

Aaronson, D. és Mazumder, B. (2008): Intergenerational Economic Mobility in the U.S., 1940 to 2000. Journal of Human Resources, 43, (1), 139-172.

Balázs Éva és Mártonfi György (2011): Az oktatás gazdasági és társadalmi környezete. In: Balázs É., Kocsis M. és Vágó I. (szerk.) Jelentés a magyar közoktatásról 2010. OFI, Budapest, 35-58.

Balázsi Ildikó és Horváth Zsuzsanna (2011): A közoktatás minősége és eredményessége. In: Balázs É., Kocsis M. és Vágó I. (szerk.) Jelentés a magyar közoktatásról 2010. OFI, Budapest, 325-362.

Beck, U. (1992): Risk Society. Towards a New Modernity. Sage, London.

Berényi Eszter, Berkovits Balázs és Erőss Gábor (2008): Iskolarend, Kiváltság és különbségtétel a közoktatásban. Gondolat Kiadó, Budapest.

Bertaux, D. és Thompson, P. (1997): Pathways to social class. A quality approach to social mobility. Claredon Press, Oxford.

Blaskó Zsuzsa (2002): Kulturális reprodukció vagy kulturális mobilitás. Szociológiai Szemle, 2, 3-27.

Boudon, R. (1974): Education, opportunity and social inequality. Wiley, New York.

Bourdieu, P. (1969): Az örökösök. A főiskolások és a kultúra. Ifjúságszociológia, 238-254.

Bourdieu, P. (1978): A társadalmi egyenlötlenségek újratermelődése. Gondolat Kiadó, Budapest.

Bourdieu, P. (1999): Gazdasági tőke, kulturális tőke, társadalmi tőke. In: Angelusz R. (szerk.) A társadalmi rétegződés komponensei. Új Mandátum Kiadó, Budapest, 138-155.

Breen, R. és Jonsson, J. O. (2005): Inequality of Opportunity in Comparative Perspective: Recent Research on Educational Attainment and Social Mobility. Annual review of Sociology, 31, 223-245. 
Breen, R. (2004): Social mobility in Europe. Oxford University Press, Oxford.

Bukodi Erzsébet (2001): A nemzedékek közötti mobilitás alakulása 1983 és 2000 között. Központi Statisztikai Hivatal, Budapest.

Csákó Mihály és mtsai (1998): A felsőfokú továbbtanulás meghatározói 1998-ban. ELTE Szociológiai és Szociálpolitikai Intézet. Budapest.

Chetty, R., Hendren, N., Kline, P. és Saez, E. (2014): Is the UNITED STATES still a land of opportunity? Recent trend in intergenerational mobility. Cambridge: NATIONAL BUREAU OF ECONOMIC RESEARCH, 33. Working Paper No. 19844 http://www.nber.org/papers/w19844

Coleman, J. és mtsai (1966): Equality of Educational Opportunity. Government Printing Office, Washington DC.

Corak, M. (2013): Income Inequality, Equality of Opportunity, and Intergenerational Mobility. American Economic Assiciation, 3, 79-102.

Davis, K. és Moore, W. E. (1999) A rétegződés néhány elve. In: Angelusz R. (szerk.) A társadalmi rétegződés komponensei, Új Mandátum Kiadó, Budapest, 391-399.

Dronkers, J. (ed.) (2010): Quality and Inequality of Education. Cross-national Perspectives. Springer Press

Esping-Andersen, G. (1993): Post-industrial Class Structures: An Analytical Framework. In: Esping-Andersen, G. (szerk.) Stratification and Mobility in Post-Industrial Society. SAGE, London, 7-31.

Eurostat (2009): European Day of Languages. http://epp.eurostat.ec.europa.eu/cache/ITY_PUBLIC/3-24092009-AP/ EN/3-24092009-AP-EN.PDF

Fehérvári Anikó (1996): A speciális szakiskolai tanulók esélyei. Educatio 5, 1, 60-70.

Fehérvári Anikó (2008): Az Arany János Programban részt vevő diákok, Educatio, 4, 512-525. http://www.edu-online. eu/hu/educatio_reszletes.php?id=71

Fehérvári Anikó (2013): Az Arany János Program. In: Hermándy-Berencz J., Szegedi E. és Sziklainé Lengyel Zs. (szerk.) PSIVET Esélyteremtés szakképzéssel. Tempus Közalapítvány, Budapest, 35-37. 
Fehérvári Anikó és Széll Krisztián (2014): Hatásvizsgálatok az oktatáskutatásban. In: Andl H. és Molnár-Kovács Zs. (szerk.) Iskola a társadalmi térben és időben 2013. Pécsi Tudományegyetem, Pécs.

Ferge Zsuzsa (1969): Társadalmunk rétegződése. Elvek és tények. Közgazdasági és Jogi Könyvkiadó, Budapest.

Ferge Zsuzsa (1980): Társadalompolitikai tanulmányok. Gondolat Könyvkiadó, Budapest.

Ferreira, F. és Ravallion, M. (2009): Poverty and Inequality: The Global Context. In: Nolan, B., Salverda, W. és Smeeding, T. (szerk.) Oxford Handbook of Economic Inequality. Oxford University Press, London.

Gamoran, A. és Long, D. A. (2006): Equality of Educational Opportunity: A 40-Year Retrospective. Wisconsin Center for Education Research, WCER Working Paper No. 2006-9

Ganzeboom, H. B. G., Treiman, D. J. és Ultee, W. C. (1998): Összehasonlító intergenerációs rétegződésvizsgálat - három generáció és azon túl. In: Róbert Péter (szerk.) A társadalmi mobilitás: Hagyományos és új megközelítések. Új Mandátum Kiadó, Budapest, 284-310.

Gazsó Ferenc (1979): Közoktatási rendszer és társadalmi struktúra. In: Társadalmi struktúrák fejlődése. 1. köt. MSZMP KB Társadalomtudományi Intézete, Budapest, 85-164.

Gazsó Ferenc és Laki László (1999): Esélyek és orientációk - Fiatalok az ezredfordulón. OKKER Kiadó, Budapest.

Gazsó Ferenc és Laki László (2004): Fiatalok az újkapitalizmusban. Napvilág Kiadó, Budapest.

Hradil, S. (1995): Társadalmi struktúra és társadalmi változás. In: Andorka R., Hradil, S. és Peschar, J. L. (szerk.) Társadalmi rétegződés. Aula Kiadó, Budapest, 347-387.

Huszár Ákos (2013): Foglalkozási osztályszerkezet (I.) - Elméletek, modellek. Statisztikai Szemle, 91, 1, 31-56.

Jencks, C. S. és mtsai (1971): Inequality. A reassessment of the Effect of the Family and Schooling in America. Basic Books, New York.

Kolosi Tamás (1987): Tagolt társadalom. Gondolat Kiadó, Budapest.

Kolosi Tamás és Keller Tamás (2010): Kikristályosodó társadalomszerkezet. Társadalmi Riport, TÁRKI, Budapest, 11. 105-138. 
Kolosi Tamás (2000): A terhes babapiskóta. Osiris Zsebkönyvtár, Budapest.

Kolosi Tamás és Róbert Péter (2004): A magyar társadalom szerkezeti átalakulásának és mobilitásának fő folyamatai a rendszerváltás óta. In: Kolosi T., Tóth I. Gy. és Vukovich Gy. (szerk.) Társadalmi Riport 2004. TÁRKI, Budapest, 8. 48-74.

Kovács Ilona (2011): Jövedelemeloszlás és jövedelemegyenlőtlenség a személyi jövedelemadó bevallási adatok tükrében. Statisztikai Szemle, 89, 3, 294-312.

Kozma Tamás (1975): Hátrányos helyzet. Egy oktatásügyi probléma társadalmi vetületei. Tankönyvkiadó, Budapest.

Kurz, K. és Müller, W. (1998): Osztálymobilitás az ipari társadalmakban. In: Róbert P. (szerk.) A társadalmi mobilitás: Hagyományos és új megközelítések. Új Mandátum Kiadó, Budapest, 256-283.

Lawton, D. (1974): Társadalmi osztály, nyelv, oktatás. Gondolat Kiadó, Budapest.

Lipset, S. M. és Bendix, R. (1991): Social Mobility in Industrial Society. Transaction Books, New Brunswick.

Liskó Ilona és Fehérvári Anikó (1996): Szerkezetváltó iskolák a kilencvenes években. Kutatás Közben. 212. Oktatáskutató Intézet, Budapest.

Liskó Ilona és Fehérvári Anikó (1998): Felvételi szelekció a középfokú iskolákban. Kutatás Közben 219. Oktatáskutató Intézet, Budapest.

Lopraeto, J. és Hazelrigg, L. E. (1998): A státusváltás attitűdbeli következményei. In: Róbert P. (szerk.) A társadalmi mobilitás: Hagyományos és új megközelítések. Új Mandátum Kiadó, Budapest, 167-173.

Lucas, S. R. (2001): Effectively Maintained Inequality: Education Transitions, Track Mobility, and Social Background Effects. American Journal Sociology, 106, 1642-1690.

Mare, R. (1981): Change and stability in educational stratification. American Sociological Review, 46, 72-87.

Medgyesi Márton (2010): Jövedelemeloszlás nemzetközi öszszehasonlításban. In: Kolosi T. és Tóth I. Gy. (szerk.) Társadalmi Riport, TÁRKI. Budapest, 11, 35-58.

Milanovic, B. (2009): Global Inequality and the Global Inequal- 
ity Extraction Ratio: The Story of the Past Two Centuries. Policy Research, Working Paper 5044, The World Bank.

Müller, W. és Shavit, Y. (1998): The institutional embeddedness of the stratification process: a comparative study of qualifications and occupations in thirteen countries'. In: Shavit, Y. és Müller, W. (szerk.) From School to Work. AComparative Study of Educational Qualifications and Occupational Destinations. Clarendon Press, Oxford, 1-48.

Nagy Péter Tibor (2010): Utak felfelé. Oktatás és társadalmi mobilitás a 19-20. századi Magyarországon. Társadalom és oktatás. Új Mandátum Kiadó, Budapest.

Nemes-Nagy József (2009): Terek, helyek, régiók. Akadémiai Kiadó, Budapest.

Németh Renáta (2006): A társadalmi mobilitás változásai Magyarországon a rendszerváltás folyamán. Szociológiai Szemle, 4, 19-35.

Nordin, M., Persson, I. és Rooth, D. O. (2010): Education-occupation mismatch: Is there an income penalty. Economics of Education Review, 1047-1059.

Pásku Judit (2013): Az iskolai teljesítményt befolyásoló pszichológiai sajátosságok és összefüggésük a munkára vonatkozó értékekkel. Életpálya-tanácsadás, 2, 52-60.

PISA 2012 Results: Excellence Through Equity. Giving Every Student the Chance to Succed (volume II). Page:334, OECD, 2013. Párizs,

Reay, D. (2006): The Zombie stalking English Schools: social class and educational inequality. British Journal of Educational Studies, 3, 288-307.

Róbert Péter és Bukodi Erzsébet: Changes in Intergenerational Class Mobility in Hungary 1973-2000. In: Richard, B. (szerk.) Social mobility in Europe. Oxford University Press, 287-314.

Róbert Péter (1986): Származás és mobilitás. Társadalomtudományi Intézet, Budapest.

Róbert Péter (1991): Educational transition in Hungary from the post-war period to the end of the 1980's. European Sociological Review, 7.

Róbert Péter (1997): Foglalkozási osztályszerkezet: elméleti és módszertani problémák. Szociológiai Szemle, 7, 2, 5-48. 
Róbert Péter (1998, szerk.): A társadalmi mobilitás: Hagyományos és új megközelítések. Új Mandátum Kiadó, Budapest

Róbert Péter (2000): Bővülő felsőoktatás - ki jut be? Educatio, 1, 79-94.

Róbert Péter (2010): The Influence of Educational Segregation on Educational Achievement. In: Dronkers, J. (szerk.) Quality and Inequality of Education. Cross-national Perspectives, Springer Press, 205-236.

Sági Matild (2003): Az iskolaválasztás oksági modellje a racionális cselekvéselmélet alapján. In: Lannert J. (szerk.) Hogyan tovább? Pályaválasztási elképzelések Magyarországon. OKI, Budapest, 52-57.

Sorokin, P. A. (1998): Az egyének társadalmi rétegenkénti minősítésének, kiválasztásának és elosztásának mechanizmusa. In: Róbert P. (szerk.) A társadalmi mobilitás: Hagyományos és új megközelítések. Új Mandátum Kiadó, Budapest, 12-26.

Székelyi Mária, Csepeli György, Örkény Antal és Szabados Tímea (1998): Válaszúton. Új Mandátum Kiadó, Budapest.

Tóth István György (2010): Jövedelemeloszlás a konszolidációs csomagok és a válságok közepette Magyarországon. In: Kolosi T. és Tóth I. Gy. (szerk.) Társadalmi Riport 2010., TÁRKI , Budapest, 17-34.

Treiman, D. és Yip, Kam-bor (1989): Educational and Occupational Attainment in 21 Countries. In: Kohn, M. L. (szerk.) Cross-National Research in Sociology. Sage, Newbury Park, 373-394.

Treiman, D. (1970): Industrialization and Social Stratification. In: Laumann, O. E. (szerk.) Social stratification: research and theory for the 1970's. The Bobbs-Merrill Company, Indianapolis, New York.

Utasi Ágnes (1984): Életstílus-csoportok, fogyasztási preferenciák. Társadalomtudományi Intézet, Budapest.

Weber, M. (1992): Gazdaság és társadalom. Közgazdasági és Jogi Könyvkiadó, Budapest.

Wilkinson, R. és Pickett, K. (2009): The spririt level: Why More Equal Societies Almost Always Do Better. Bloomsburry Press. 



\section{GÖNCZI IBOLYA}

\section{A gyermekvédelem és az iskola}

\section{Bevezető gondolatok}

A különböző kultúrákban a gyerekek családon belüli pozíciója, értéke folyamatosan változik, átalakul, napjainkban egyre nagyobb jelentőséget kap, hazánkban különösen. A pozitiv gyermekszemlélet mögött jól kitapintható az egyes tudományterületek (antropológia, lélektan, pedagógia) kutatási eredményei mentén, valamint a társadalmi, gazdasági folyamatokban érzékelhető fejlődés. Egyúttal elbizonytalanodás is tapasztalható a gyermekek helyzetével, szocializációjával, nevelésével kapcsolatosan, ami összefüggésbe hozható magának a családnak az újradefiniálásával, megváltozásával, megítélésével. Buda Béla korábbi írásában ezzel összefüggésben a következőképpen fogalmazott: „A családdal ugyan már évtizedek óta foglalkoznak különböző diszciplínák, de ezek nem tudták még a család lényegét megragadni, a szemléletet fogva tartották az adott korszak relevanciái és előfeltevései, problématudati megkötöttségei. A család mint kommunikációs, emocionális és kognitív viszonyrendszer teljesen más megközelítést igényel, mint a korábbi családlélektané vagy családszociológiáé." (Buda,1994:41) Változatlanul fontos a család mint a társadalom alapegysége, ugyanakkor különböző válságtünetek mint nevelési kudarcok, devianciák, konformitás, értékrendetlenség megjelenése is szembeötlő.

Aligha vitatható, ugyanakkor empirikus vizsgálatokkal talán nehezen alátámasztható, hogy az embernek bevallott vagy bevallatlan vágya a gyermek után, patetikusan fogalmazva az örökkévalóságra törekvése, ősidők óta benne munkál. A gyermek, aki az ember életének lényegét, értelmét, örömét 
hordozza, igazolja, elsősorban önmaga kiteljesítését jelenti. A gyerekek, családok életének láncolatán, folytonosságán át igazolódik az örök élet és valósulhat meg a halandók földi létének örökkévalósága. A hétköznapok során tudatosan vagy észrevétlen, de bizonyossággal átélt, még is oly sokszor nehezen kifejezhető érzések, amelyek a gyermek fogantatásának pillanatától örvénylenek a szülőkben, ideális esetben egyetlen forrásból táplálkoznak, a szeretetből. A társ, a megszülető gyermek és az ember önmaga iránti szeretetből. Abból az emócióból, amely tulajdonképpen az én kiterjesztése saját és mások fejlődésének érdekében mutatkozik meg. Ebben az értelmezésben benne rejlik az önfejlesztés folyamata annak a célnak a tükrében, hogy így az ember környezetében jelenlévők is fejlődnek, és felfedezhető ebben az erőfeszítés, az akarat is. Feltételezhető, hogy a szeretet mindenkiben él. Kérdés azonban, hogy képes-e valamennyi földi halandó ennek az érzésnek az intenzív megélésére, átélésére? Túlságosan messzire vezetne a szeretet fogalmának további, mélyebb értelmezése. Egy olyan titok nyomába kellene eredni, amelynek megfejtéséhez az időkereteken túl vélhetően a szavak korlátolt világával is illik számolni.

A gyerekek életében különösen nagy, mondhatni létfontosságú szerepe van a szeretetnek. Ez alapozza meg - különösen az első három életévben - a gyermekek számára azt a fizikai és lelki kapcsolatot egy állandó személlyel (optimális esetben az édesanyával), amely az állandóság, az érzelmi biztonság kialakulásának a záloga, s amely a szocializáció során a szülőktől való majdani leválást is elősegíti, megkönnyíti, természetessé teszi.

Természetesen azoknak a gyermekeknek, akiknek nem adatik meg, hogy a legmeghittebb, a személyiségfejlődésüket leginkább biztosító közösségben, egészséges életvitelű családban növekedjenek, is „megtörténik” valahol életminőségük fejlesztése, segítése. A származási családjukból önhibájukon kívül kényszerüen kikerülő gyermekek előbb-utóbb tagjaivá lesznek egy tőlük idegen, olykor nehezen elviselhető, de az érdekeiket mindenekelőtt szem előtt tartó rendszernek, a gyermekvédelmi ellátórendszernek. Ebből az értékrendből kiindulva is indokolt a hazánkban is deklaráltan állami feladatként ér- 
telmezhető gyermekvédelmi rendszer folyamatos fejlesztése, és mint társadalmi gyakorlatnak a nyilvánosság biztosítása.

\section{A gyermekvédelemmel kapcsolatos fogalmak}

A gyermekvédelem a szociálpolitikába ágyazottan, de attól elkülönítetten is koronként, kultúránként változó tartalommal, és holisztikus, multidiszciplináris jelleggel értelmezhető. Minden olyan országban, ahol a gyermeket értékként becsülik, komoly diskurzusok folynak arról, hogy a felelősségvállalás és a kötelezettségek teljesítése tekintetében hogyan határozhatók meg, és hogyan érvényesíthetők legadekvátabban a szülők, a gyerekek és az állam jogai, valamint felelőssége.

Egy rendszer felépítésének, múködési logikájának értelmezése feltételezi a tárgykörével összefüggő fogalmak ismeretét. A gyermekvédelem definiálása a rendszer interdiszciplináris jellegéből fakadóan összetett tartalmi elemekkel jellemezhető. És mivel minden társadalmi berendezkedés, kultúra saját gyermekvédelmi gyakorlattal írható le, az értelmezési keret is koronkénti változatosságot mutat. Az alábbi fogalommeghatározások nem vállalkoznak történelmi korszakok jellemzésére, egyértelműen a 20. századi hazai tényszerű megállapításokra szorítkoznak.

\section{Gyermekvédelem}

„...a gyermek- és ifjúságjóléti gondozás: a család, a hatóság és társadalom által foganatba vett azon intézkedések és általuk alkalmazott berendezések összessége, amelyeket a fiatalkorúak gazdasági, testi, szellemi-erkölcsi javának elömozdítását célozzák a megszületéstől az önjogúság eléréséig." (Csorna, 1929:8)

„...a gyermekvédelem a gyermek testi, szellemi, erkölcsi, anyagi érdekeit elömozdító szociális, jogi, egészségügyi és pedagógiai tevékenységek és intézkedések összessége." (Új Magyar Lexikon, 1960:III:138) 
„...A gyermekvédelem mindazoknak a pedagógiai, jogi, egészségügyi és szociális tennivalóknak összessége, amelyek a veszélyeztetett gyermek nevelését, eltartását, munkába állitását, érdekvédelmi és egészségügyi gondozását biztosítják." (Pedagógiai Lexikon, 1977:III:85)

„....speciális gyermekvédelmi tevékenység ... az elárvult, az elhagyott vagy a veszélyeztetett helyzetben levö gyermek, fiatalkorú felkarolására, pártfogásra, védelmére irányul. A speciális gyermekvédelem csupán része a tágabb tartalmú általános gyermek- és ifjúságvédelemnek, amely kiterjed a gyerekek, a fiatalok szocializációjában szerepet játszó intézményekre mint a család, az iskola, az ifjúsági szervezetek stb. - felöleli a gyerekek, az ifjúság fizikai, szellemi, erkölcsi, valamint munkára nevelésének valamennyi területét." (Hanák, 1978:15)

„A gyermek- és ifjúságvédelem tehát a családpolitika rendszerébe is és a köznevelés rendszerébe is tartozik. Ezek létét és múködését pedig törvények és más jogszabályok határozzák meg. A gyermek- és ifjúságvédelem így válik elméletben és gyakorlatban is komplex területté, amelynek összetevői között a leglényegesebbek: a jogi, a szociális, az egészségügyi, a közgazdasági, a pszichológiai területek. Mivel azonban a gyermek és családjuk életében mindezek egyedi módon érvényesülnek, a gyermekvédelmi problémáik összegeződnek; ezért a gyermekvédelem szemléleti alapja a gyermek személyiségfejlődése egészét segítő pedagógiai szemlélet. Minden tudomány és minden gyakorlati eljárás a pedagógiának van alárendelve a gyermekvédelmi esetekben. A gyermekek érdekeit legjobban a pedagógiai érdek fejezi ki." (Gáti, 1987:7)

„A gyermekvédelem a társadalom kultúraátadó és -fejlesztő tevékenységének a része, amelyben biológiai, egészségügyi, múvelődési (ezen belül elsősorban pedagógiai és pszichológiai), szociális, pszichés, jogi és igazgatási feltételek komplex biztosításával segíti, intézményein keresztül szervezi, hogy a felnövekvő nemzedék pozitív természeti és szociokulturális hatásokban részesüljön, így megteremtödjenek annak feltételei, hogy az egyének elérhessék személyiségfejlődésük felső hatá- 
rát, majd az érett felnöttséget. Ugyanakkor a társadalomnak segíti feltárni, elemezni gazdasági, társadalmi müködésének zavarait, és együttesen küzdenek azok megszüntetéséért. Közben támogatják a hátrányos helyzetbe kerülteket, továbbá a különböző veszélyek miatt biológiai-fiziológiai, szociális és pszichés sérülést átélt fiatalok korrigáló személyiségfejlesztő neveléséröl pedig gondoskodnak, hogy mind a kisebb, mind a nagyobb csoportokba, közösségekbe beilleszkedni képes emberekké váljanak." (Veczkó, 1990:121)

„A gyermekvédelem szélesen értelmezve azokra a valamilyen okból veszélyeztetett gyerekekre vonatkozik, akik akár szociális, akár érzelmi vagy más irányú deprivációjuk, testi vagy szellemi fogyatékosságuk miatt szorulnak fokozott támogatásra, igényelnek kiemelt figyelmet és segítséget. Ebbe a tág értelmezésbe bele kell érteni azt a megelőző gyermekvédelemnek nevezett tevékenységet is, amelybe a megelőzés, gondoskodás és utógondozás is beletartozik fogalmilag." (Herczog, 1997:5)

„...a gyermekvédelem széles értelmezésébe a társadalmi lét, társadalmi tevékenység minden olyan szférája beletartozik, amely az adott társadalom gyermekkorúnak tekintett népességével kapcsolatba hozható." (Domszky, 1997:9)

Volentics Anna „Gyermekvédelem és reszocializáció” című hiánypótló kiváló múvében a gyermekvédelmi rendszer múködésének alapjául tekinti az adott társadalom által elfogadott és elvárt azt az egységes tevékenységrendszert, amelyben egyértelműen kifejeződik és megvalósul az érintettek szükségleteinek és jogainak maradéktalan érvényesítése, a szélesen értelmezett prevenciós keretek és tartalmak figyelembevételével. (Volentics,1999)

„...gyermekvédelem minden olyan tevékenység, amit a gyermek harmonikus fejlödése, fejlődő képességeinek kibontakoztatása érdekében a család, az egészségügyi, oktatási és minden más ágazat, illetve bármely intézmény, szolgáltató, szakember tesz. .... a speciális gyermekvédelem a bármely okból veszélyeztetett, árva, elhagyott, bünelkövető és speciális 
szükségletü (pl. fogyatékos, halmozottan hátrányos helyzetü, menekült), vagy más okból fokozottan védelemre szoruló gyermek támogatását és védelmét szolgálja. .... állami felelősséget és feladatot jelent, amely a különleges és fokozott védelemre szoruló gyermekek jogait és érdekeit óvja hatósági eszközökkel." (Herczog és Katonáné Pehr, 2011:21)

A fent bemutatott meghatározások alapján is kijelenthető (és bizonyára található még számos definíció), hogy a gyermekvédelem összetett, komplex tartalmi jegyekkel jellemezhető fogalom, praxis, értelmezhető szűken, tágan, általánosan vagy speciálisan.

A magunk megközelítése alapján a gyermekvédelem egyszerre tudományterület és társadalmi gyakorlat, amely egyidejüleg jelenti a gyermekek, ifjak, családok védelmét a megelözés, a valamilyen beavatkozás, a segítés és utógondozás eszközeivel együtt. Ebből a kiindulásból következik és érvényesül az a lényegi szempont is, hogy a figyelem, a segítés nem csak a krizishelyzetben lévőkre fókuszál. Fontos tehát egyértelmúsíteni azt is, kik a rendszer által ellátottak milyen szempontok mentén jellemezhetők. Általánosságban és hangsúlyozottan a veszélyeztettek, hátrányos helyzetben lévők, a deviánsok mint önálló társadalmi csoport tagjaira gondol a közvélemény, miközben nem feledhető, hogy a prevenció deklarált vállalása és széles körüen értelmezett tartalma szempontjából a gyermekvédelmi ellátás rendszere kiterjed a társadalom teljességére, azaz minden gyermek- és fiatalkorúra és családjukra.

\section{Veszélyeztetettség}

A fogalomalkotás és -értelmezés természetesen nem öncélú nyelvészeti bravúrkodás. Egy-egy fogalom magában hordozza az adott korszaknak a tárgykörrel kapcsolatos politikai, ideológiai, gazdasági szempontú állásfoglalását. A társadalomban zajló változásokkal együtt alakulnak át, kapnak más, árnyaltabb jelentést a különböző meghatározások. Adekvát példa erre a szegénység értelmezésének változása. Hazánkban a 20. század elején a szegénység önmagában veszélyeztetettséget jelentett, aminek kiváltó oka alapvetően anyagi természetű 
volt. Napjainkban azonban a veszélyeztetettség tartalma valamelyest megváltozott, árnyaltabbá vált. Az anyagi okok hiányából fakadó veszélyeztetettség mellé felsorakozott a túlzott anyagi jólét jelensége mint veszélyeztető tényező. Századokkal ezelőtt a szegény néprétegben a nyomor, az anyagi elesettség esetenként predesztinálta a deviáns életforma alakulását is (bűnözés, fiatalkori prostitúció). Ahogy utaltunk rá, napjainkban azok a gyerekek, fiatalok is veszélyeztetettek, akiknek családjában nem a valódi odafigyelés, a szerető és szigorú gondoskodás a jellemző, hanem esetenként az egyáltalán nem korlátozó, csak az anyagiakban kifejeződő ellátás. E mögött a jelenség mögött jól kitapinthatók az eltelt néhány évtizedben lejátszódott gazdasági, politikai változások, az ezekből eredeztethető, napjainkra oly jellemző reménytelenül összekuszált értékrend, az élet szinte minden területére jellemző morális válság. A veszélyeztetés, a veszélyeztető környezet egyaránt lehet természeti és társadalmi jellegű, értékromboló hatásával a gyermek, fiatal személyiségfejlődését lassíthatja, torzíthatja. Előfordul, hogy a gyermek, a fiatal képes közömbösíteni önerejéből vagy külső segítőkkel az ártó hatásokat, ezekben az esetekben akár mentesülhet is a különböző testi, fiziológiai, pszichés traumáktól és azok következményeitől. A veszélyeztetett fogalom tartalmi szempontból összetettebb. Vannak gyerekek, akik különböző testi, lelki, értékfelfogásbeli károsodást átéltek, személyiségalakulásuk folyamatosan akadályozott. És vannak olyan gyerekek, akik személyiségükben már károsodtak, és ennek következtében különböző viselkedési zavarokat mutatnak. Nagy szakmai felelősség pontosan diagnosztizálni, hogy a kiskorút ért ártó hatások, azok nemkívánatos negatív élményei mikor kezdik megbontani a személyiség belső egyensúlyát, mikortól kezdődnek a viselkedési zavarok. A veszélyeztetettség megítélésekor Gáti Ferenc szerint indokolt figyelembe venni az alábbi tényezőket:

- „ártalomforrás, amely puszta létével vagy csak némán fenyeget a háttérből, vagy valóban múködő erő;

- ártalomhatás, ami erejétől, fajlagosságától és időtartamától függően károsítja a gyereket;

- gyermeki személyiség, ami a prediszpozíciójától függően 
ellenáll a hatásoknak, kivédi vagy kisebb-nagyobb mértékben elszenvedi azokat;

- károsodások, a személyiségben bekövetkezett negatív értékú állapotváltozások, amelyek további károsodások eredői is." (Gáti, 1982:17)

\section{Hátrányos helyzet}

A gyermekvédelemben gyakran használt, és fontos kifejezés a hátrányos helyzet megnevezés is. E fogalom kapcsán kevésbé a negatív kulturális hatások érvényesüléséről, felerősödéséről beszélhetünk, inkább arról, hogy a gyermek adott környezete bizonyos szempontból (szellemi, anyagi, technikai értelemben) elmaradottabb, így lassúbb fejlődést tud biztosítani, valamint az érintett családok, rétegek az érettség alacsonyabb szintjén maradnak. „Hátrányos helyzetűeknek nevezzük azokat a gyerekeket és fiatalokat, akik iskolai kudarcot szenvedtek: megbuktak, sőt lemorzsolódtak már az alsófokú oktatás során. Nyilvánvaló, így azt a bonyolult problematikát, amelyet a tanügy-igazgatási szóhasználatban és a társadalomtudományi kutatómunkában hátrányos helyzetként jelölnek, a maga teljességében nem tudjuk megragadni" (Kozma, 1975:23).

A hátrányos helyzetű tanulókkal történő pedagógiai foglalkozás, szociális törődés a fogalom értelmezésének szempontjából vet fel jó néhány kérdést. Végigkövetve a törvényi szabályozás változásait az alábbi módosításokat fontos szem előtt tartani.

$\mathrm{Az}$ ismeretes, hogy 2013. augusztus 31-ig a közoktatást szabályozó 1993. évi LXXIX törvény 121. \&-a tartalmazta a hátrányos, halmozottan hátrányos helyzet fogalmát. A jelzett két évtized alatt, a társadalmi folyamatokban bekövetkezett változások hatására finomodott, változott a hátrányos helyzet megítélése. Egészen 2005-ig az alábbiak szerint összegezhető a fogalomértelmezés:

Hátrányos helyzetű gyermek, tanuló az, akit családi körülményei, szociális helyzete miatt 
a) a jegyző védelembe vett, illetve

b) aki után rendszeres gyermekvédelmi támogatást folyósítanak;

e két szempont mellett halmozottan hátrányos helyzetü gyermek, tanuló,

a) akinek a törvényes felügyeletét ellátó szülője legfeljebb az iskola nyolcadik évfolyamán folytatott tanulmányait fejezte be sikeresen, feltéve, hogy a szülő a gyermek, tanuló után rendszeres gyermekvédelmi támogatásra jogosult, továbbá

b) az a gyermek, az a tanuló, akit tartós nevelésbe vettek.

2008-ban már változik az értelmezés, a következők szerint: hátrányos helyzetű gyermek, tanuló az, akit családi körülményei, szociális helyzete miatt

a) a jegyző védelembe vett, illetve

b) akinek rendszeres gyermekvédelmi kedvezményre való jogosultságát a jegyző megállapította;

ezen belül halmozottan hátrányos helyzetü gyermek, tanuló

a) akinek a törvényes felügyeletét ellátó szülője - a gyermekvédelmi törvény alapján szabályozott eljárásban tett önkéntes nyilatkozata szerint - óvodás gyermek esetében a gyermek három éves korában, tanuló esetében a tankötelezettség beállásának időpontjában legfeljebb az iskola nyolcadik évfolyamán folytatott tanulmányait fejezte be sikeresen, és

b) az a gyermek, tanuló is, akit tartós nevelésbe vettek.

A nemzeti köznevelésröl szóló 2011. évi CXC. törvény (továbbiakban: Nkt.) már nem szerepelteti a hátrányos helyzet fogalmát, ez átkerült az 1997. évi XXXI. évi törvénybe, amely a gyermekek védelmét és a gyámügyi igazgatást szabályozza (továbbiakban: Gyvt.). Ennek következtében 2013 szeptemberi hatállyal a hátrányos, halmozottan hátrányos helyzetü gyermek (fiatal felnőtt) fogalma és ennek megállapítása a gyermekvédelmi gondoskodás körébe tartozó hatósági intézkedés lett. A 
szabályozások célja a gyermekek hátrányainak kompenzálása, esélyeik növelése, a minél sikeresebb társadalmi integrációjuk segítése. A törvény szövegéből az következtethető, hogy a hátrányos helyzetet meghatározó gyermekvédelmi kedvezményre való jogosultság alapvetően a családok anyagi helyzetét mutatja, és nem jelenti, nem fejezi ki egyértelmüen a gyermek életminőségét, az iskolai sikerességét kedvezőtlenül befolyásoló egyéb hátrányokat (lakáskörülmények, szülők munkanélkülisége), ami a pedagógiai munka szempontjából különösen fontos, figyelembe veendő szempont. 2013-tól megítélésünk szerint tovább szigorította a jogszabályi megfogalmazás a hátrányos helyzet értelmezését az alábbiak alapján:

Hátrányos helyzetü az a rendszeres gyermekvédelmi kedvezményre jogosult gyermek és nagykorúvá vált fiatal felnőtt, aki esetében az alábbi körülmények közül egy fenn áll:

a) a szülő vagy a családba fogadó gyám alacsony iskolai végzettsége, ha a gyermeket egyedül nevelő mindkét, vagy az egyedül nevelőről - önkéntes nyilatkozat alapján - megállapítható, hogy a rendszeresen gyermekvédelmi kedvezmény igénylésekor legfeljebb alapfokú iskolai végzettséggel rendelkezik;

b) a szülő vagy a családba fogadó gyám alacsony foglalkoztatottsága, ha megállapítható, hogy a rendszeresen gyermekvédelmi kedvezmény igénylésekor aktív korúak ellátására jogosult (1993. évi III. Szociális törvény 33. §) vagy a gyermekvédelmi kedvezmény igénylésének időpontját megelőző 13 hónapon belül legalább 12 hónapig álláskeresőként nyilvántartott személy;

c) a gyermek elégtelen lakókörnyezete, lakáskörülményei, ha megállapítható, hogy a gyermek a településre vonatkozó integrált városfejlesztési stratégiában szegregátumnak nyilvánított lakókörnyezetben vagy félkomfortos, komfort nélküli vagy szükséglakásban, illetve olyan lakáskörülmények között él, ahol korlátozottan biztosítottak az egészséges fejlődéséhez szükséges feltételek.

Halmozottan hátrányos helyzetü az a rendszeres gyermekvédelmi kedvezményre jogosult gyermek és nagykorúvá vált fiatal felnőtt, aki esetében 
a) a fenti pontokban meghatározottak közül legalább kettő fenn áll,

b) a nevelésbe vett gyermek,

c) valamint az utógondozói ellátásban részesülő és tanulói vagy hallgatói jogviszonyban álló fiatal felnőtt.

A hátrányos helyzetű tanulók számára a köznevelési törvény a különböző kedvezményekről is rendelkezik. Példaként említhető, hogy az Nkt. 16. § (3) alapján az állami fenntartású és az állami feladatellátásban közreműködő alapfokú művészeti iskolákban heti hat tanóra foglalkozás biztosított térítési díj ellenében a főtárgy elméletének és gyakorlatának elsajátításához, továbbá tanévenként egy meghallgatás és egy művészi előadás, és e szolgáltatások körében az iskola létesítményeinek, felszereléseinek használata. Minden esetben ingyenes a hátrányos, a halmozottan hátrányos helyzetű, a testi, érzékszervi, enyhe és középsúlyos értelmi fogyatékos, az autizmus spektrum zavarral élő tanuló részére az első alapfokú múvészetoktatásban való részvétel. E törvény 50 . §-a szerint, ha a településen több általános iskola múködik, az egyes általános iskolai körzetet úgy kell meghatározni, hogy kialakíthatóvá váljon a halmozottan hátrányos helyzetű gyermekek egyenletes aránya a nevelési-oktatási intézményekben. Ha az általános iskola a felvételi kötelezettsége teljesítése után további felvételi, átvételi kérelmeket is teljesíteni tud, előnyben kell részesíteni a halmozottan hátrányos helyzetű gyermekek, tanulók felvételi kérelmét [Nkt. 51. § (1)].

Ezzel összefüggésben kell megemlíteni, hogy a Gyvt. 12. §-a értelmében a szülők jogosultak arra, hogy a gyermekük fejlődését segítő ellátásokról tájékoztatást, neveléséhez segítséget kapjanak. Ily módon szinkronban az állam támogatásának szükségességét, tehát az állami és a szülői felelősségvállalás közti egyensúly fontosságát deklarálja az ENSZ A Gyermekek Jogairól szóló Egyezmény 18. cikkelye, amely szerint az állam kötelessége, hogy tájékoztassa a szülőket a gyermekeik iránti felelősségük tartalmáról, és felkészítse őket ennek gyakorlására. Az Egyezményt a Magyar Köztársaság 1990. március 14-én írta alá, és 1991-ben törvénybe iktatta (1991. évi LXIV. törvény) 
A jogalkotói alapelvek mentén a család szerepének prioritása, hangsúlyozása a gyermeknevelésben szembeötlő. A gyermek gondozására és nevelésére elsősorban a vérszerinti családja jogosult, és köteles is, amelyhez segítséget nyújt az állam, az önkormányzat. Az ENSZ Gyermekjogi Egyezményével szinkronban az Gyvt. is egyértelmúen kifejezésre juttatja minden gyermek esélyegyenlőségét és társadalmi befogadását célzó és szolgáló univerzális ellátórendszer kialakítását, valamint múködtetését, amelyek értelmében biztosítani kell:

- a gyermek mindenekfelett álló érdekét,

- a gyermek saját családjában való nevelkedésének jogát,

- a család minden módon való segítését a gyermek minél jobb gondozása, nevelése érdekében,

- a gyermek különös védelmét a bántalmazás és elhanyagolás ellen,

- a fogyatékos gyermek fokozott védelmét,

- a gyermeket megilletö helyettesítő védelmet,

- a gyermek elhelyezésének időszakos felülvizsgálatát.

\section{7. évi XXXI. törvény a gyermekek védelméről és a gyámügyi igazgatásról}

A kormány a törvényt 1997. február 4-én Dr. Kökény Mihály akkori népjóléti miniszter előterjesztésében ismerhette meg, $s$ kezdődhetett el a törvényjavaslat vitája. Az országgyűlés végszavazására a tárgyév április 22-én került sor, amelynek eredménye 224 igen, 2 nem és 32 tartózkodás volt. Így Magyarországnak 96 esztendő után ismét lett önálló törvénye a gyermekek védelmének.

A magyarországi gyermekvédelmi törvény nem szorítkozik az eddigi, gyermekvédelemre vonatkozó széttagolt jogszabályok összefoglalására, néhány új ellátás és intézkedés törvényi szintű megfogalmazására. Ennél már címében is többet foglal magában. Hatálya kiterjed a hazánk területén élő magyar és nem magyar állampolgárságú gyerekekre, de kihatással van a 18-24 éves fiatal felnőttek azon körére is, akik kiskorúként korábban gyermekvédelmi ellátásban részesültek, s önmagukról (a törvény hatályba lépésekor 24 éves korukig) nem képesek gondoskodni. 
A törvény célja, hogy megállapítsa, rögzítse a gyermekek jogait, azok érvényesítésének garanciáit, a gyermekek védelmének rendszerét, az egyes ellátási formákat, azok fő szabályait és a gyámügyi igazgatás szervezetét. A jogszabály alapelve a gyermeket/gyermekeket nevelő családok többirányú támogatása. Ennek értelmében pl. gyermeket a családból kiemelni csak akkor lehet, ha a támogatások ellenére a veszélyeztető körülmények a családon belül nem szüntethetők meg. A hatósági intézkedéseket minden esetben meg kell, hogy előzze valamennyi, a gyermekre kiterjedő, az alapellátás keretében múködő ellátás felajánlása a családnak, amelynek igénybevétele természetesen önkéntes. A törvény egy hosszú távon fenntartható, családi típusú nevelésre irányuló rendszer kialakítását, a megelőző és a családba való visszahelyező megoldásokat ösztönzi, helyezi előtérbe. A gyermekek védelmében azonban egyértelműen kellő hangsúlyt kap a nevelés, gondozás, a habilitáció és a rehabilitáció is. A kialakítandó új ellátó- és szolgáltatóstruktúra illeszkedik a helyi önkormányzatok feladat- és hatásköréhez, szakmai szolgáltató és koordináló szerepüket kívánja erősíteni, markánsan szétválasztva a hatósági, valamint a szolgáltatói tevékenységet.

A gyámügyi igazgatási terület korszerúsítése a gyermekek személyi és egyúttal vagyoni érdekvédelmét is szolgálja. Így tehát a családjából hatósági intézkedéssel kiemelt gyermeknek olyan gondozást, nevelést kell biztosítani, amely felkészíti, ezáltal alkalmassá is teszi az önálló életre. Ennek érdekében többek között fejleszti az addig kialakított nevelőszülői hálózatot, prioritást biztosít képzéseknek, továbbképzéseknek, amelyek reálisan elérhetők a nevelőszülőknek. Másrészről fontos céltételezés az örökbefogadás „megkövesedett” szabályainak egyszerűsítése is. A törvényi rendelkezés elővételezte meghatározott időn belül a bentlakásos intézményhálózat korszerūsítését. (A korábbi intézménystruktúra teljes átalakítását 2002ig irányozta elő a szakmai állásfoglalás.)

A gyermekvédelmi feladatok hatékony, kézzelfogható, mérhető eredményeket hozó ellátása érdekében a törvény a korábbi évek gyakorlatához képest újszerű munkamegosztást érvényesített. Ennek szellemében a települési önkormányzatok feladata a helyi ellátórendszer, az alapellátás kiépítése és 
működtetése, a területén lakó veszélyeztetett gyermekek ellátásának megszervezése (gyermekvédelmi támogatások, gyermekjóléti szolgáltatás, gyermekek napközbeni ellátása, átmeneti gondozása, a máshol igénybe vehető ellátásokhoz történő hozzájárulás megszervezése).

A megyei önkormányzatok hatásköre és kötelezettsége biztosítani a személyes gondoskodást nyújtó szakellátások keretén belül az otthonszerü ellátást és a területi gyermekvédelmi szakszolgáltatást.

A törvényben pontosan rögzítésre került a mindenkori fenntartó irányítási és törvényességi ellenőrzési jogköre is. A megyei önkormányzatoknak mint az intézmények fenntartóinak el kell látniuk az irányítási jogkörükbe tartozó feladatokat. Így döntenek a gyermek-, lakás- és speciális otthonok, a területi gyermekvédő szakszolgálat alapító okiratáról, nevéről, átszervezéséről, megszüntetéséről, gazdálkodási és tevékenységi köréről, annak módosításáról. Meghatározzák az intézmények költségvetését, az intézményi térítési díjakat, ellenőrzik az intézmények gazdálkodását és múködésük törvényességét. Jóváhagyják az intézmények szervezeti és múködési szabályzatát, szakmai programját, értékelik a szakmai munka eredményességét. A szakmai munka eredményességének érdekében elkerülhetetlen a folyamatos együttmúködés a különböző intézmények között. Fontos és betartandó szempont azonban, hogy a megyei irányítás ne sértse az intézmények szakmai programjukban meghatározott önállóságát. A megyei önkormányzatok kötelessége a gyermeki jogok védelme is. Ezt elsősorban a gyermekvédelmi szakellátások, a szülői vagy más hozzátartozói gondoskodásból kikerülő gyermekek helyettesítő védelmének biztosításával nyújthatja. Ennek értelmében, az intézményekben érdekképviseleti fórumot és gyermek-önkormányzatot kell létrehozni. Az érdekképviseleti fórumban a szavazati joggal rendelkező választott tagok az intézményt fenntartó megyei önkormányzat képviselői.

$A z$ átalakított gyermekvédelmi rendszerben szükségszerüen megerősödtek az együttmúködési és kapcsolati rendszerek is.

A megyei és települési önkormányzatok szempontjából: a szakellátási és alapellátási rendszer kiépítéséhez és hatékony múködtetéséhez elengedhetetlen feltétel a megyei és tele- 
pülési önkormányzatok szoros együttmüködése. Egy megyei önkormányzatnak a területi gyermekvédelmi szakszolgáltatás megszervezése során ki kellett építenie egy szaktanácsadói, szakértői centrumot. A gyermekvédelmi szakszolgáltatás szaktanácsadás keretében szakmai, módszertani segítséget nyújt az alapellátás szintjén működő személyes gondoskodást biztosító intézmények számára. A települési önkormányzatok gyermekjóléti szolgálatai és a megye területi gyermekvédelmi szakszolgálata konkrétan együtt tevékenykednek a gyermek családjába való visszailleszkedésének, önálló életvitelének elősegítéséhez.

A megyei önkormányzatok és gyámhivatalok szempontjából: A városi és megyei gyámhivatalok feladatainak ellátásához a megyei önkormányzat egyrészt a személyes gondoskodást nyújtó otthonok és nevelőszülők múködtetését biztosítja, másrészt a területi gyermekvédelmi szakszolgálat munkatársai a gyámhivatalok mellett múködve, azok irányítása mellett végzik tevékenységüket, szakértelmüket szolgáltatásként biztosítva. A gyámhivatalok ellenőrzik a személyes gondoskodást nyújtó ellátást, véleményezik az ellátórendszer átalakítására vonatkozó javaslatokat. A megyei gyámhivatal szakmai koordinációs értekezleteket jogosult összehívni a hatósági, módszertani, továbbképzési és ellenőrzési feladatok szakszerűbb ellátásának, a szakmai tevékenység továbbfejlesztésének érdekében. A gyámhivatalok szakmai felügyeleti és ellenőrző tevékenysége - különös tekintettel a megyei gyámhivatal e szerepére - olyan új elem a család, gyermek és ifjúságvédelem területén, amely garantálja a törvényességet, a szakmai normák érvényesülését a területen közreműködő valamennyi hatóság, intézmény és szolgáltató esetében. Ennek megvalósulásában a megyei önkormányzatnak mint a szakellátást fenntartó szervezetnek hatékonyan kell közreműködnie.

A gyermekotthonok szempontjából: A gyermekotthonok kötelessége a törvény értelmében együttmúködni a családdal foglalkozó gyermekjóléti szolgálattal, a területi gyermekvédelmi szolgálattal, a gyámhivatallal.

A családjukból kikerülő gyermekek helyettesítő védelmét biztosító gyermekotthonok, a gyermekjóléti szolgálatok és a területi gyermekvédő szakszolgálat szakembereivel összefogva 
teremthetik meg annak a lehetőségét, hogy a gyermek családjával rendszeresen kapcsolatot tarthasson, illetve családjába visszakerülhessen. Biztosítaniuk kell az alapellátás felé az információáramlást, a szakemberek személyes konzultációját az otthonban elhelyezet gyermekek, fiatal felnőttek érdekében álló segítő tevékenység számára. A gyermekek egyéni gondozási-nevelési terve elkészítéséhez mind a gyermekjóléti szolgálat, mind a szakszolgálat érintett szakembereinek ismereteit, tudásanyagát, szakvéleményét be kell építeni. Szükség van tehát olyan kapcsolódási pontokra, olyan rendszeres szakmai megbeszélésekre, ahol valamennyi érintett szakember a komplex ismeretek birtokában tesz javaslatot a gyámhivatal felé a gyermek szempontjából legjobb döntés meghozatalához.

A védelem alól kikerülő gyermekek utógondozása, otthonteremtési támogatása a gyermekotthon és a települési önkormányzat együttes feladata. A gyermekotthonok a gyámságból adódó feladataikat a területi gyermekvédelmi szakszolgálat szakembereinek közremúködésével és szakmai ellenőrzése mellett látják el. A különleges szakértelmet igénylő ügyekben, vagy ha a gyám a gyermekotthon vezetőjeként a gyermeket nem képviselheti, a hivatalos gyám végzi a munkát. A gyámság ellátásához szükséges feltételek kialakításához, ismeretek elsajátításához szükséges folyamatosan az e területen dolgozó szakemberek tapasztalatcseréje, továbbképzések szervezése. A gyermekotthonok felvállalhatnak a személyes gondoskodás keretébe tartozó alapellátási feladatokat mint szolgáltatást. Adott településen élő gyermekek napközbeni ellátásának, átmeneti gondozásának biztosítása elősegítheti a gyermekotthon elfogadását, beilleszkedését a területen. Profitálhatnak ebból az önkormányzatok is oly módon, hogy nem kell külön ellátórendszert kiépíteniük ezekre a feladatokra.

A törvényben szabályozott új típusú gyermekotthonok, lakásotthonok kialakítása lehetőséget adott arra, hogy ezen intézmények jobban beilleszkedjenek az adott települési környezetbe. A családi házak, lakásotthonok helyét területileg úgy kellett megválasztani, hogy az ott élő gyermekek beilleszkedése a település, a község, városrész mindennapjaiba sikeresen, zökkenésmentesen történhessen. Korábban ugyan a nagy létszámú nevelőotthonok is ezer szállal kapcsolódtak a 
múködési területükön lévő intézményekhez, az ott lakó emberekhez, azonban az elkülönültségük, elszigeteltségük az épületeik, területük mérete, adottságai miatt is nyilvánvaló volt. Fontos cél volt, hogy olyan kapcsolatrendszer alakuljon ki az otthonokban, amely az előítéletek leküzdésének érdekében számol a szomszédok, barátok, önkéntes segítők, támogatók bevonásával, ugyanakkor bevonja a település oktatási, szociális, kulturális, gazdasági, infrastrukturális környezeti erőit a gyermekek, fiatal felnőttek életesélyeinek növeléséhez, s kiaknázza az ebben rejlő lehetőségeket.

A gyermekotthonok egy részében a jövőben is megmarad a belső iskolai oktatás. Ez ott és akkor indokolt, ha az otthonban speciális oktatást igénylő gyermekek élnek nagyobb számban, és a településen nincs mód a képzésük biztosítására. A kapcsolatok ezért kétirányúak maradnak. A gyermekotthon úgy is, mint a gyermek gyámságát ellátó intézmény, kvázi „szülő” kapcsolata az iskolával, ahová a gyermek jár. Másrészt, mint „iskola”, ahová a településen élő gyermekek járnak. Szakmailag elsősorban az indokolt, hogy az otthonban élő gyermekek a külső, a településen múködő iskolába járjanak, szerezzék meg a megfelelő képesítést. Beilleszkedésüket, önállóságukat az szolgálja leginkább, ha azonos feltételekkel veszik igénybe az oktatást, mint a családban nevelkedő társaik. Alapelv az is, ha mód van rá, a gyermek tanulmányi kötelezettségeit a családból történő kiemelése esetén is az eredeti tanintézményében folytathassa. Különösen fontos, hogy a gyermekeknek biztosítani kell saját kulturális hagyományaik, szokásaik megismerését, gyakorlását is. Az ellátórendszerben nevelkedő tehetséges fiatalok számára is támogatást kell nyújtani tehetségük kibontakoztatása érdekében. A szabadidő hasznos eltöltése, a civil szervezetekhez való csatlakozás vagy saját klubok, egyesületek szervezése elősegítheti a fiatalok integrálódását a társadalomba. A gyermekotthonok kapcsolata a településen lévő családokkal, gyermekeket segítő szociális intézményekkel, hatóságokkal lehet a legintenzívebb.

A törvény szövegének ismeretében megállapítható az is, hogy néhány új fogalommal kellett a szakembereknek, de az hétköznapok emberének is megismerkedni. Első olvasatkor persze riasztónak tűnik, tünhet mindez. 
A gyermekjóléti ellátás és a gyermekvédelmi gondoskodás fogalmának megkülönböztetése abból a szempontból lényeges, hogy az ellátó funkciókat határozottan el kell választani az úgynevezett hatósági tevékenységektől. Ahogy a törvény szellemiségéből is következik, a családokat, a gyermekeket elsősorban a különböző támogatások, ellátások önkéntes igénybevételével kell segíteni, s hatósági kényszert, intézkedést csak éppen az önkéntesség hiánya esetén és csak a feltétlenül szükséges és elégséges mértékben szabad alkalmazni, s ezen közben is lehetőség szerint meg kell tenni mindent a családok együttmúködéséért. Ugyanakkor ez az elv azt is magában foglalja, hogy szükségszerű együttműködést kell biztosítani, kialakítani a szolgáltató valamint a hatósági tevékenységek között is.

új fogalomként és gyakorlatként jelent meg a gyermekjóléti szolgálat és a gyermekvédelmi szakszolgálat megnevezés is, amelyek korábban nem múködtek, új intézményeket is jelentettek.

Az alapellátások - amelyek alapvetően a személyes gondoskodásra irányulnak - elsődleges célja, hogy lehetőség szerint ne kelljen a családi közösségek életét közigazgatási határozatokkal megbolygatni, a család ahhoz kapjon sokrétű (jogi, életvezetési, gyermekneveléssel kapcsolatos stb.) segítséget, hogy önerejét ne veszítse el, képes legyen gyermekei felnevelésére. Ebben az értelemben van óriási szerepe és felelőssége a gyermekjóléti szolgálatoknak, amelyek az átalakuló hazai gyermekvédelmi rendszerben új szervezeti formaként jelentek meg.

A gyámügyi eljárást szabályozó 149/1997 (IX. 10.) kormányrendelet szerint minden városban múködnie kell gyámhivatalnak. Ezzel összhangban a városokban gyermekjóléti szolgálatokat kell létrehozni, különböző feltételek alapján és nagyságrendben, amelyeket elsősorban az határoz meg, hogy helyi vagy térségi működésűek lesznek-e.

A jóléti szolgálatok feladataik ellátásának elengedhetetlen feltétele (a végrehajtási utasítások alapján szabályozva) a megfelelő szakmai végzettséggel rendelkező szakemberek alkalmazása. A mindennapok gyakorlatában ez azt jelenti, hogy a segítő szakemberek mindenekelőtt képesek az ügyfeleket hivatalos ügyeik intézésében segíteni, tájékoztatni, egészségügyi, jogi, pedagógiai tanácsadással szolgálni, egyáltalán fel- 
ismerni azt, hogy milyen jellegű speciális tanácsadásra van szüksége a hozzájuk forduló klienseknek. A szolgáltatások közvetítésének legfontosabb feltétele az önkéntesség biztosítása és az együttmüködés feltételeinek megteremtése. A gyermekjóléti szolgálatok a gyermekek veszélyeztetésének megelőzése érdekében észlelö- és jelzőrendszert építenek ki és müködtetnek az adott térségben, koordinálják és összehangolják a gyermekvédelmi rendszerhez kapcsolódó feladatokat ellátó szerveket és szakembereket. A jelzőrendszer eredményes és hatékony működésének érdekében a gyermekjóléti szolgálat (központ) esetmegbeszéléseket, esetkonferenciákat tart, évente átfogó áttekintést ad a település gyermekvédelmi munkájáról. A törvényesség alapján is elvárás, hogy az észlelőés jelzőrendszer tagjai egymást kölcsönösen tájékoztassák, a veszélyeztetettség mértékéhez és a család aktuális szükségleteihez igazodóan minden lehetséges eszközzel a veszélyeztető körülmények megszüntetését segítsék.

Hasonló elvárásoknak kell megfelelniük az iskolai gyermekvédelmi feladatokat ellátóknak, a gondozási-nevelési tervek elkészítéséhez, ahhoz a döntéshez pl. hogy szükséges-e hatósági beavatkozás igénybevétele egy-egy konkrét eset kapcsán.

A különböző alapellátási formák (gyermekek napközbeni ellátásának speciális formái: családi napközi, házi gyermekfelügyelet stb.) átlátható, célorientált múködése is megkívánja a naprakész információs rendszer kiépítését.

Azok a városok, ahol már müködtek családsegítő központok, szolgálatok, ott nyilván könnyebb helyzetben voltak, vannak ebből a szempontból a jóléti szolgálatok. Az ott dolgozó szakemberek tapasztalatai, helyismeretük, jól funkcionáló információs hálózatuk, kapcsolataik mind garanciái annak, hogy a bővülő hatásköröket viszonylag kisebb zökkenőkkel integrálják korábbi tevékenységükbe. 


\section{1. ábra. A gyermekvédelmi rendszer struktúrája}

a feladatok tartalma és színtere mentén

(forrás: Herczog és Katonáné Pehr, 2011, szerk.)

\begin{tabular}{|c|c|}
\hline TELEPÜLÉSI ÖNKORMÁNYZAT & JEGYZÖ \\
\hline \multirow[t]{3}{*}{$\begin{array}{l}\text { - gyermekjóléti alapellátások biztosítása } \\
\text { - rendkivüli gyermekvédelmi támogatás } \\
\text { - önkormányzati támogatások (pénzbeli, termé- } \\
\text { szetbeni) } \\
\text { - gyermekjóléti szolgáltatás, központok } \\
\text { - gyermekek napközbeni ellátása (bölcsőde, csa- } \\
\text { ládi napközi, házi gyermekfelügyelet) } \\
\text { - gyermekek átmeneti gondozása (átmeneti } \\
\text { otthonok: családok, gyermek számára, helyettes } \\
\text { szülö) }\end{array}$} & $\begin{array}{l}\text { - rendszeres gyermekvédelmi kedvezmény } \\
\text { - kiegészíő gyermekvédelmi támogatás } \\
\text { - védelembe vétel } \\
\text { - családi pótlék természetbeni formája } \\
\text { - iskoláztatási támogatás felfüggesztése } \\
\text { - ideiglenes elhelyezés } \\
\text { - gyermekjóléti szolgáltatás működésének engedélyezése } \\
\text { - apai elismerő nyilatkozat } \\
\text { - ügygondnok }\end{array}$ \\
\hline & VÁROSI GYÁMHIVATAL \\
\hline & $\begin{array}{l}\text { - gyermektartásdij megelölegezése } \\
\text { - otthonteremtési támogatás } \\
\text { - ideiglenes elhelyezés } \\
\text { - nevelésbe vétel } \\
\text { - nevelési felügyelet elrendelése } \\
\text { - családba fogadás } \\
\text { - örökbefogadás } \\
\text { - utógondozás } \\
\text { - kapcsolattartási, vagyoni ügyek } \\
\text { - gyámság, gondnokság }\end{array}$ \\
\hline $\begin{array}{l}\text { MEGYEI, MEGYEI JOGÚ VÁROSI, FŐVÁROSI } \\
\text { ÖNKORMÁNYZAT }\end{array}$ & MEGYEI GYÁMHIVATAL \\
\hline $\begin{array}{l}\text { - gyermekvédelmi szakellátás } \\
\text { - területi gyermekvédelmi szakszolgáltatás } \\
\text { (szakértői bizottság, hivatásos gyámi és } \\
\text { nevelőszülői hálózat, családgondozás, } \\
\text { utógondozás) } \\
\text { - otthont nyújtó ellátás: különleges, speciális, } \\
\text { nevelőszülö, gyermekotthon } \\
\text { - utógondozás }\end{array}$ & $\begin{array}{l}\text { - elsőfokú gyámhatóságok szakmai felügyelete } \\
\text { - másodfokú döntések meghozatala } \\
\text { - gyermekvédelmi intézmények müködésének engedélye- } \\
\text { zése, ellenőrzése } \\
\text { - gyermek- és ifjúságvédelmi koordinátori feladatok }\end{array}$ \\
\hline
\end{tabular}

\section{MINISZTÉRIUM}

- ágazati irányítás, szakmai felügyelet

- közvetlen intézmények fenntartása: javítóintézetek, speciális gyermekotthonok

- központi hatósági feladatok

- országos örökbefogadási nyilvántartás

\section{SZOCIÁLIS ÉS MUNKAÜGYI INTÉZET}

- országos gyermekvédelmi szakértői bizottság

- országos gyermekvédelmi szakértői névjegyzék

- másodfokú döntések

- ágazati regiszter müködtetése 


\section{Gyermekvédelmi feladat és szolgáltatás a közoktatás/köznevelés színterén}

A fentiekkel összefüggően a gyermekvédelem mint állami feladat megvalósításának egyik színtere a közoktatás/köznevelés valamennyi intézménye, kiemelten az óvodák és az iskolák. Jogszabályok rögzítik, hogy a nevelési-oktatási intézmények is közremúködnek a gyerekek, tanulók veszélyeztetettségének megelőzésében, megszüntetésében, együttmúködnek a gyermekvédelmi rendszerhez kapcsolódó teendőket ellátó intézményekkel, hatóságokkal.

A gyermek- és ifjúságvédelemmel összefüggő feladatok megoldásában a pedagógusoknak segítséget nyújtanak a gyermekjóléti szolgálatok. A nevelési-oktatási intézményekben jól látható helyen ki kell függeszteni az ifjúságvédelmi felelős nevét, fogadóóráját, valamint azoknak a központoknak, intézményeknek az elérhetőségét (gyermekjóléti szolgálat, pedagógiai szakszolgálatok, ifjúsági lelkisegély-telefon, drogambulancia, gyermekek átmeneti otthona), ahol az aktuális problémái megoldásában segítséget kérhet az érintett tanuló, illetve a szülei. Vélelmezett vagy bizonyított veszélyeztető helyzetben lévő tanulók segítése érdekében a gyermekvédelmi felelősnek kezdeményezni kell, hogy az intézmény vezetője értesítse a gyermekjóléti szolgálatot. Ezen túlmenően tájékoztatnia kell a gyermekjóléti központ utcai szociális munkását a csellengő, kallódó, hiányzó gyerekekről, akik iskolai időben nem jelennek meg a tanórákon, különösen akkor, ha tudomása van a gyerekek tartózkodási helyéről. Ez az együttmúködés intenzívebbé, eredményesebbé teszi, teheti a szociális munkások tevékenységét is. Ezek mellett feladata még a gyermekvédelmi felelősnek, hogy megismerje a veszélyeztetett tanulókat, és családlátogatáson a szülőkkel, pedagógusokkal történő beszélgetés során feltárja a gyermeket, a tanulót veszélyeztető okokat, továbbá a gyermekjóléti szolgálat megkeresésére vegyen részt az esetmegbeszéléseken. A tanuló anyagi veszélyeztetettsége esetén kezdeményezze az iskola igazgatójánál, hogy indítson eljárást az illetékes települési önkormányzat polgármesteri hivatalánál a gyermekvédelmi támogatás megállapítása érdekében, esetleg a támogatást természetbeni ellátás formájában 
nyújtása céljából. A gyermek- és ifjúságvédelmi felelős segíti a kábítószer elleni program kidolgozását, végrehajtását.

A gyermekvédelmi feladatok köréhez tartozik a nevelésioktatási intézményekben a képességkibontakoztató és az ezzel szorosan összefüggő integrációs felkészítés is. A tanulók szociális helyzetéből és egyéni adottságaiból eredeztethető hátrányok kompenzálását az iskola saját erőforrásai, személyi és infrastrukturális lehetőségei alapján szervezi, és biztosítja a képességfejlesztést, a tehetségesek támogatását, a felzárkóztatást, a tanulási, továbbtanulási esélyek kiegyenlítését. (Herczog és Katonáné Pehr, 2011)

A jogszabályi környezet változásainak következtében a fent egyértelműsített gyermekvédelmi felelős státusz biztosítása napjainkban nem egyértelmű a nevelési-oktatási intézményekben.

Egyrészt a köznevelési törvény szövege alapján minden pedagógusnak feladata a gyermekvédelemmel kapcsolatos feladatok ellátása. Másrészt a törvény nem kötelezi direkt módon az intézményfenntartót, hogy az e feladatkörhöz státuszt biztosítson. A tartalmak közvetítői, a feladatok megoldói tehát a gyermekvédelmi feladatokat is ellátó pedagógusok, valamint, ha az intézményekben alkalmazhatók, akkor segítő szakemberek pl. szociális munkások, szociálpedagógusok, mentálhigiénikusok, pszichológusok, gyógypedagógusok. Fontos megjegyezni, hogy ezeknek a segítő szakembereknek a jelenlétét, alkalmazását legitimálta, tehát az intézmények fenntartói számára kötelezően előírta már az 1997-ben hatályossá lett gyermekvédelmi törvényünk előtt az 1996-ban módosított közoktatási törvény. A közoktatási törvény további módosításainak eredményeként sajnálatosan a 2000-es évek elejére a fenntartó szervek ilyen irányú kötelezettsége a „kötelező” kategóriából a „lehetségesbe” lágyult. A jelenleg hatályos nemzeti köznevelési törvény bevezetésekor még fenntartói hatáskörbe utalta annak eldöntését, hogy biztosít-e az adott köznevelési intézményben gyermekvédelmi felelősi státuszt vagy sem. A törvény megjelenését követően már módosult e tekintetben, kikerült a törvényből a fenntartói döntés lehetősége a gyermekvédelmi felelős státusz biztosítására. A törvény 
szövege alapján nem vitatható, hogy a jogszabály változatlanul kiemelt területként kezeli az intézményekben folyó gyermekés ifjúságvédelmi feladatok ellátását. Az intézményvezetők felelősségi/hatáskörébe sorolja e feladatok megszervezését és ellátását, abból kiindulva, hogy ennek a tevékenységnek az ellátása alapvetően a nevelési-oktatási intézmények helyi adottságaitól, helyzetétől függ. Tehát az intézményvezető szükség szerint bízhat meg egy pedagógust a feladat ellátásával, tekintettel a helyi adottságokra [Nkt. 69. § (1) bekezdés f) pont]. A jogalkotó kötelezővé teszi azonban az intézmények számára, hogy az alapdokumentumaikban - SZMSZ, pedagógiai program - részletesen határozzák meg a nevelési-oktatási intézményben a külső kapcsolatok rendszerét, formáját, módját, nevezetesen a gyermekjóléti szolgálattal való kapcsolattartást, a gyermekvédelemmel összefüggő pedagógiai munkát, a legkülönfélébb tevékenységeket.

Ez a szabályozási mechanizmus megítélésünk szerint mégis neuralgikus pontja az óvodai, iskolai nevelés gyakorlatának. Miért is?

Az 1990-es évektől nyomon követhető társadalmi dezintegrációs folyamatok napjainkig éreztetik hatásukat, és az ebből kirajzolható tendencia sem biztató. Az elmúlt években lezajlott országos és helyi szintű szociológiai és gyermekvédelmi kutatások eredményei is folyamatosan jelzik, hogy a gyerekek egyre jelentősebb hányada diszharmonikusan múködő, hátrányos helyzetű családokból (munkanélküliség, devianciák, válás), illetve a tartós nevelésbe vett státusból érkezik az óvodákba, iskolákba (Homoki, 2005; Varga, 2008; Rácz és mtsai, 2012; Varga, 2012). Ezekre a gyerekekre különösen jellemzők pl. az agresszív viselkedés különböző módozatai. Ezeknek a diákoknak a szociális érzékenysége, a munka- és tanulási motivációja, a tanuláshoz való beállítódása sokszor rendkívül alacsony szintű. Egyre többüknél halmozottan jelentkeznek a legkülönbözőbb jellegú és tartalmú problémák. A veszélyeztető szociális környezeti ártalmak a fejlődő, alakuló személyiségstruktúra egészére gyakorol negatív hatást. Így ennek a tanulói népességnek a kognitív képességei, a tehetsége gyakran éppen a szociális háttértényezőik miatt marad rejtve, és csak abban az esetben mutatkozik meg, amikor sikerül valamelyest a 
szociális jellegű hátrányokat kompenzálni, elhárítani. De megemlíthető ezeknek a gyerekeknek, fiataloknak a társas kapcsolataiban megmutatkozó egyre durvább viselkedési módozatok és az autoagresszivitás jelenségének terjedése is.

A szociokulturális okokból következtethető hátrányok kompenzálása, a veszélyeztetettség lokalizálása, jó esetben a megszüntetése pedagógiai, pszichológiai, szociális/szociálpolitikai alapozottságú feladat is. Természetesen az egyes konkrét esetek ismeretében akár hatósági, jogi beavatkozások is indokoltak lehetnek. Az óvodák, iskolák környezetében, a gyerekek világában nem lehet kérdéses a pedagógiai megoldások prioritása, szemben a hatósági intézkedésekkel. Ebből kiindulva a nevelési intézményekben megjelenő problémás, konfliktusos esetek kezelése, a beavatkozások elsősorban segítő folyamatként értelmezendők, amelyekben kiemelkedő szerepet kap a kreatív, jól felkészült pedagógusteam és mellette a különböző speciális ismeretekkel, szociális jellegű tudással és/vagy végzettséggel is rendelkező ifjúságvédelmi feladatokat ellátó pedagógus vagy a segítő szakember. Az oktatásügy, a család-, gyermek- és ifjúságvédelem intézményei a funkcióik teljesítése szempontjából tehát értelmezhetők a segítségnyújtás, az elsődleges és másodlagos prevenció terepének.

Végiggondolva a pedagógia fejlődési irányait is, kirajzolódik és erősödik az az irányzat, amely szerint egyre hangsúlyozottabbá válik, és kellene, hogy váljon a gyerekek segítése és fejlesztése során maga a nevelői hatás. A kifejezetten iskolai folyamatokra koncentráló pedagógia elkezdett az iskolán kívüli területekre is figyelni, és tevékenységi körét az iskolán túlra kiterjeszteni. A pedagógia, a nevelés, a fejlesztés szerepének, jelentőségének hatása nyomon követhető a különböző szakterületeken is, pl. az igazságszolgáltatásban, joggyakorlatban, az egészségügyben, a szociálpolitikában. Megerősödött az a szemlélet, miszerint a család és az iskola mellett a különböző társadalmi alrendszereknek is vállalniuk kell bizonyos pedagógiai-nevelési feladatokat. A hagyományos, „hivatásos pedagógustevékenység" mellett megjelent (nem napjaink találmányaként!) egy új, „nem oktató pedagógus” modell, feladatkör, elnevezésében a szociálpedagógus. Ő az a szakember, aki a feladatait, teendőit tekintve már nem a megszokott értelem- 
ben tanár (ismeretközvetítő a tanítási órákon), de még nem is az a szakember, aki az ifjúságvédelmi törvények alapján szerveződő újabb intézményekben mint ifjúsági gondozó vagy szociális ügyintéző tevékenykedik. A szociálpedagógusok nyújtják, nyújthatnák az egyes életkori szakaszokban azokat a szolgáltatásokat, ellátásokat az óvodákban, iskolákban is, amelyek nagyban hozzájárul(hat)nak a családok támogatásához, az oktatási intézmények szocializációs törekvéseinek megvalósulásához.

Ezért is ébred kételkedés a szakemberekben, vajon a legmegnyugtatóbb változások felé vezet-e jelenleg az oktatáspolitikának ebben a kérdéskörben vállalt azon véleménye és immár a gyakorlatban bevezetett döntése, amikor is a nevelési, oktatási intézményekben a felmerülő problémás helyzetek, olykor devianciák kezeléséhez a hatósági, rendészeti szereplőket is konkrétan megjelenteti a mindennapi munkafolyamatban. Az vitán felül áll, ha az oktatási intézményekben felmerülő konkrét probléma, konfliktus megoldásában a pedagógiai eszközök és eljárások eredménytelenek, akkor alapvetően és kizárólag a konkrét helyzet alapján következhet a jogi, hatósági keretek adta feltételek és lehetőségek bevonása. Azonban a bizonyosságok és dokumentálható történések alapján már nem szükségszerűen a nevelési intézményekben kellene folytatódni a további megoldási módozatoknak.

Nézőpontot váltva, egy másik érv is kétségessé, kérdésessé teszi a rendőrség mint hatóság megjelenését az oktatás-nevelés intézményeiben. A rendőri tevékenységek mint hatósági feladatok alapvetően a felderítésre irányulnak. Az oktatáspolitika által preferált értékrend szerint is hangsúlyozottá vált a prevenció a rendőrség munkájában (a búnmegelőzés, a drogfogyasztás és más függőségek területén), aminek megkérdőjelezhetetlenül fontos üzenete van a tanulók és a szülők számára. Az is tapasztalat, hogy a rendőrség előirt és vállalt sokrétű prevenciós programjai évek óta igazoltan hatékonynak bizonyulnak az oktatás világában. A produktivitás, a tényleges eredményesség szempontjából a rendőrségnek ezt a típusú tevékenységét, megítélésünk szerint mégis a tanórákat követve, főként az iskolák szervezeti keretein kívül, egyéb színtereken lenne érdemes megszervezni, lebonyolítani. Ezt az érvelésünket azzal támaszthatjuk alá, hogy a széles tárgykörű prevenciós feladatokba be- 
vonhatók már az egyre inkább felkészült pedagógusok mellett az egészségügy szakemberei, a kortárs segítők, és szerencsés esetben az iskolákban alkalmazásban lévő, a fentebb már megemlített segítő foglalkozású szakemberek is.

\section{Összegzés}

A gyermekvédelmi törvényből kiolvasható, hogy a nevelési-oktatási intézmények közremúködnek a gyermekek, tanulók veszélyeztetettségének megelőzésében és megszüntetésében, ennek során együttműködnek a gyermekjóléti szolgálattal, illetve a gyermekvédelmi rendszerhez kapcsolódó feladatokat is ellátó más személyekkel, intézményekkel, hatóságokkal. Kitűnik az is, hogy amennyiben a nevelési-oktatási intézményben dolgozó pedagógus vagy alkalmazott segítő szakember - amennyiben észlelve a gyermeket, a tanulót veszélyeztető okokat, azokat pedagógiai eszközökkel már nem tudja megszüntetni - a gyermek-, tanulóközösség védelme érdekében indokolt esetben külső szakemberek segítségét is kérheti. Az oktatás szereplői, elsősorban a pedagógusok, jól tudják, hogy az elsődleges prevenció területén kiemelt szerepe van a gyermekjóléti szolgálatoknak. A gyakorlatban ez azt jelenti, hogy ők múködtetik, koordinálják a gyermekvédelmi jelzőrendszert a veszélyeztetettség elkerülése, illetve megszüntetése érdekében mindazokkal az intézményekkel és szervezetekkel, amelyekkel a gyermek közvetlenül maga vagy a szülei révén kapcsolatban van vagy kerülhet ( $p l$. az egészségügy, védőnő, házi orvos, az oktatás, a hatósági, gyámhivatali, igazságszolgáltatás, rendőrség, az egyházak, az alapítványok szereplői).

E szemlélet és a kiépített eljárásmód szempontjából is aggályosnak túnik a hatósági szakemberek jelenléte a nevelési-oktatási intézményekben. Arról már nem is szólva, hogy az ő státusuk sem egyértelmű az intézmény, a tantestület közösségében.

Egy szakmailag körültekintően kidolgozott és az aktuális élethelyzetekhez adaptívan viszonyuló, folyamatosan múködtetett és múködő gyermekvédelmi rendszer és gyakorlat hatékonysága vagy esetenkénti eredménytelensége a mindenkori 
társadalmi, gazdasági, kulturális struktúrában értelmezhető, ítélhető meg viszonylagos realitással. Talán az sem igényel már különleges érvrendszert, hogy az állam polgárainak egészségi, mentális biztonsága akkor nem lesz kétséges, ha a létfeltételeik is elősegítik az emberi kapcsolatok ápolását, gazdagítását, az egymásra figyelést, ha a gyermek mint érték nem úgy értelmezendő a családok életében, mint szociális támogatási lehetőség, ha nem megélhetési forrássá minősül, hanem a szeretet, a harmónia, az életigenlés megtestesítőjeként tekintenek rá. Vélhetően a gyermek tiszteletén alapuló értékrend is hozzájárulhat a sérült gyerekek, felnőttek, családok számának csökkenéséhez. Ugyanakkor az sem kétséges, hogy mindig lesznek olyan gyerekek, fiatalok, akik kényszerűen kikerülnek vérszerinti családjukból az ott átélt lelki vagy fizikai bántalmazás miatt, függetlenül attól, hogy az ország, ahol élnek gazdasági csoda vagy annak éppen az ellenkezője.

\section{Irodalomjegyzék}

\section{Felhasznált irodalom}

Buda Béla (1994): Kell-e reformálni a családot? Humán Reform, Budapest.

Csorna Kálmán (1929): A szociális gyermekvédelem rendszere. Eggenberger Könyvkereskedés, Budapest.

Csókay László, Domszky András, Hazai Vera és Herczog Mária (1997, szerk.): A gyermekvédelem nemzetközi gyakorlata. Pont Kiadó, Budapest.

Csürös Zoltán (1960): Új Magyar Lexikon. Akadémiai Kiadó, Budapest.

Domszky András (1997): Bevezető gondolatok a gyermekvédelem értelmezéséhez. In: Csókay László, Domszky András, Hazai Vera és Herczog Mária (szerk): A gyermekvédelem nemzetközi gyakorlata. Pont Kiadó, Budapest.

Gáti Ferenc (1982/1987): Gyermekvédelem az iskolában. Tankönyvkiadó, Budapest.

Hanák Katalin (1978): Társadalom és gyermekvédelem. Akadémiai Kiadó, Budapest. 
Herczog Mária és Katonáné Pehr Erika (2011, szerk.): A gyermekvédelem nagy kézikönyve. Complex Kiadó JÜT Kft, Budapest.

Homoki Andrea (2005): Jövőképek és életesélyek. Az „aranyhal esete" a gyermekvédelmi gondoskodás alatt álló fiatalokkal. In: Szretykó Gy. (szerk.) Az ifjúság helyzete és jövőképe. Adalékok az ifjúság szociológiai elemzéséhez. Comenius Bt. Pécs, 233-250.

Kozma Tamás (1975): Hátrányos helyzet. Tankönyvkiadó, Budapest.

Nagy Sándor (1997, főszerk.): Pedagógiai Lexikon. Akadémiai Kiadó, Budapest

Rácz Andrea és mtsai (2012): Gyermekvédelemben nevelkedettek helyzete a kutatások tükrében. In: Rácz A. (szerk.) Gyermekvédelemben nevelkedettek társadalmi integrációs esélyei. Gyermek és Ifjúságvédelmi Tanulmányok. Rubeus Egyesület, Budapest.

Varga Aranka (2008): A gyermekvédelemben élők inklúziójának esélyei. Új Pedagógiai Szemle, 9, 16-24.

Varga Aranka (2012): Padtárs vagy kórtárs - A gyermekvédelmi szakellátó rendszerben élők iskolai sikereinek lehetőségei. Kutatási jelentés. Educatio, 7-8, 238-279.

Veczkó József (1990): A gyermekvédelem pszichológiai és pedagógiai alapjai. Tankönyvkiadó, Budapest.

Volentics Anna (1999): Gyermekvédelem és reszocializáció. Nemzeti Tankönyvkiadó, Budapest.

\section{Jogszabályok}

1991.évi LXIV. törvény 1991. évi LXIV. törvény a Gyermek jogairól szóló, New Yorkban, 1989. november 20-án kelt Egyezmény kihirdetéséről

1993. évi III. törvény a szociális igazgatásról és szociális ellátásokról (net.jogtar.hu 2014. XI. 16.)

1993. évi LXXIX. törvény a közoktatásról (net.jogtar.hu 2014. $X I .16$.

1997/XXXI. törvény a gyermekek védelméről és a gyámügyi igazgatásról (net.jogtar.hu 2014. XI. 16.)

149/1997(IX.10.) Kormányrendelet a gyámhatóságokról vala- 
mint a gyermekvédelmi és gyámügyi eljárásról(net.jogtar. hu 2015.07. 29.)

2011. évi CXC törvény a nemzeti köznevelésről (net.jogtar.hu 2014. XI. 16.)

2011. évi CLXXXIX. törvény a helyi önkormányzatokról (net. jogtar.hu 2014.XI.16.)

\section{Ajánlott irodalom}

Bagdy Emőke (1986): Családi szocializáció és személyiségzavarok. Tankönyvkiadó, Budapest.

Barkó Éva (1995, szerk.): A gyermekbántalmazás Magyarországon. NM, Budapest.

Fromm, E. (1993) A szeretet müvészete. Háttér Kiadó, Budapest.

Gáti Ferenc (1987): Gyermekvédelem az iskolában. Tankönyvkiadó, Budapest.

Gerevich József (1989, szerk.): Közösségi mentálhigiéne. Gondolat Kiadó, Budapest.

Homoki Andrea (2012): A gyermek- és ifjúságvédelmi felelősök munkavégzéséhez kapcsolódó dilemmák. Educatio, 21, 1, 151-158.

Pikó Bettina (2005): Ifjúság, káros szenvedélyek és egészség a modern társadalomban. L' Harmattan Kiadó, Budapest.

Pukánszky Béla (2001): A gyermekkor története. Műszaki Kiadó, Budapest.

Rácz József (1989): Ifjúsági szubkultúrák és fiatalkori devianciák. Magyar Pszichiátriai Társaság, Budapest.

Varga Aranka (2008): A gyermekvédelemben élők inklúziójának esélyei. Új Pedagógiai Szemle, 9, 16-24.

Várnagy Elemér (1976): Gyermek- és ifjúságvédelem. Tankönyvkiadó, Budapest.

Várnagy Elemér és Várnagy Péter (2000): A hátrányos helyet pedagógiája. Corvinus Kiadó, Budapest.

Veczkó József (1966): Gyermek- és ifjúságvédelem. Tankönyvkiadó, Budapest.

Veres Sándor és Brezovszky Sándor (1989): A képzettségi hátrányok okai az állami gondozottak körében. Gyermek- és ifjúságvédelem, 1-2, 67-78. 



\section{Esélyegyenlőség és inklúzió az iskolában}

\section{Bevezetés}

A 21. századi iskolákat egyre inkább a társadalmi és kulturális sokszínűség jellemzi szerte a világon, mely kihívásra különböző válaszok születnek. Közös szemléleti pont az esélyegyenlőség biztosítása, mely a támogató környezeti feltételek mentén megvalósuló tanulmányi sikerességben ölt testet. A következőkben az esélyegyenlőség alapvetéseiből kiindulva és a különböző társadalmi együttélési stratégiákat sorra véve jutunk el az inkluzív (kölcsönösen befogadó) társadalmi és oktatási megközelítésig. Röviden kitérünk olyan elméletekre, amelyek alátámasztják az inklúzió szükségességét - fókuszálva az iskolára. Végezetül pedig felrajzoljuk azt a modellt, amely az inkluzív nevelés kialakításának iskolai kereteit adja, valamint összegezve bemutatjuk a társadalmi stratégiák gondolatmenetünk mentén konstruált rendszerét. ${ }^{1}$

\section{Egyenlő bánásmódtól a méltányos szolgáltatásokig}

Az esélyegyenlőség (equality) a jogállamiságot megalapozó demokratikus követelmény, mely magában foglalja az egyenlő lehetőségeket (equality of opportunities), valamint az egyenlő bánásmódot (equal treatment), mint ugyanannak a jelenségnek a kétféle megközelítését. (Keller és Mártonfi, 2006) A jogszabályokban is rögzített esélyegyenlőségi elv garantálja, hogy az alapvető jogok, valamint az emberi méltóság mindenki számára megkülönböztetés nélkül biztosított legyen. 
Az így teremtett egyenlő jogi státusz és a tényleges társadalmi helyzet között azonban eltérések lehetnek. A legnagyobb egyenlőtlenség társadalmi-szociális területen mutatkozik, ami a társadalmi javakhoz való hozzáférés, illetve a társadalmi javakhoz vezető utakon jelentkező egyenlőtlenségeket jelenti. Az egyenlőtlenségek hátterében olyan okok állnak, mint a tőketulajdonlási különbségek (Bourdieu, 1997) - beleértve a szimbolikus (kulturális, társadalmi és szociális) tőkét is -, illetve okként jelenik meg az eltérő társadalmi megítélés a nemi és a nemzeti-etnikai-vallási csoportok között, illetve a fogyatékos személyekre vonatkozóan. A valódi társadalmi egyenlőség csak azzal biztosítható, ha a jogrend és a hozzá kapcsolódó társadalmi cselekvések figyelembe veszik a fennálló egyenlőtlenséget, és az eltéréseket az egyenlőtlenségükre tekintettel kezelik. (Varga, 2013)

Az esélyegyenlőségre törekvés kétféle megközelítést tesz szükségessé, mely kettőség fogalmi szinten is megjelenik. Különbséget teszünk az esélyegyenlőség (equality) és az egyenlő esélyek (equity) biztosítása között. Az esélyegyenlőség (equality) elsősorban az egyenlő hozzáférés azonos módon való biztosítását, más megközelítésben az egyenlő bánásmódot, illetve a hátrányos megkülönböztetés tilalmát jelenti. Az egyenlő bánásmód alkalmazásával lehet megelőzni, hogy emberek és csoportok kirekesztődjenek a társadalomban fellelhető lehetőségekhez való hozzáférésből. (Varga, 2012) Az esélyegyenlőség (equality) elsősorban tehát azt a demokratikus társadalmi minimumot garantálja, hogy senki ne kerüljön hátrányba valós vagy vélt egyéni adottságai vagy valamely csoporthoz való tartozása miatt. ${ }^{2}$ Ennek biztosítását célozza az Európai Unióban az Emberi Jogok Európai Egyezménye 14. cikke (Kézikönyv... 2011), Magyarországon pedig a 2003. évi CXXV. törvény az egyenlő bánásmódról és az esélyegyenlőség előmozdításáról. ${ }^{3}$ A jogi dokumentumok megnevezik a kizáródással veszélyeztetett csoportok széles körét és megfogalmazzák a kiemelt figyelem módját is, melyek célzott beavatkozást teremtenek a hátrányban élők egyenlő hozzáférése érdekében. ${ }^{4}$

Az esélyegyenlöség (equality) vagy egyenlö bánásmód értelmezésünkben tehát azt jelenti, hogy a hátrányos megkülönböztetés tilalmából adódóan valamennyi személynek és 
csoportnak jogilag garantált lehetösége van másokkal közös térben és másokkal azonos módon és arányban hozzáférni információkhoz, tevékenységekhez, szolgáltatásokhoz, eszközökhöz stb.

Az angolszász „equity” kifejezés - melynek magyar megfelelője a „méltányosság” - az „equality”-hoz képest azt hangsúlyozza, hogy a hátrányt okozó különbségtétel kizárása szükséges, de nem elégséges feltétel a valódi esélyegyenlőség létrejöttéhez. (Radó, 2000, 2007) A méltányosság a hátrányos megkülönböztetés tilalma mellett azon támogató feltételek biztosítását jelenti, melyek a társadalomban megmutatkozó különbségek (méltánytalanságok) ellensúlyozásaként alkalmazott intézkedések, cselekvések. A támogató eszközök és aktív cselekvés segítségével jön létre mindenki valódi hozzáférése, teremtődik meg egyenlő esélye. Vagyis tenni kell azért, hogy az egyenlőtlen helyzetben lévők is részesülhessenek a felkínált javakból. A szakmai diskurzus egyre inkább elhagyja az esélyegyenlőség (equality) fogalmát, és a méltányosság (equity) fogalomkörébe sorolja mindazon tevékenységeket és a mögöttük meghúzódó szemléletet, mely megteremti a társadalom minden szegmensében és valamennyi tagja számára az egyenlő esélyek feltételeit.

A méltányosság az emberi jogi megközelítésen túl az oktatási rendszerek és diákjaik sikerességének egyik fontos kritériumaként is megjelenik. Az oktatásban megnyilvánuló méltányosság sokféle módon mérhető, és jelentősége is más a különböző értelmezési keretekben. Ma már szerte a világon osztják azt a nézetet, hogy a hatékonyság, eredményesség és méltányosság metszetében helyezkedik el a minőségi oktatási környezet (Lannert, 2004). A hatékonyság az oktatási ráfordításokat és megtérülésüket jelzi, az eredményesség a mérhető kimenetet mutatja, a méltányosság pedig a hatékonyság és eredményesség valamennyi tanulóra való kiterjedésének szükségességét hangsúlyozza. Az oktatási rendszerek átfogó mérését hároméves ciklusonként végző PISA (Programme for International Student Assessment $)^{5}$ vizsgálatok is folyamatosan kitérnek ebben a hármas egységben megjelenő minőségi mutatóra. (OECD, 2013) Azokat az oktatási rendszereket tekintik példaértékűnek ${ }^{6}$, melyekben az oktatásra történő 
ráfordítások (hatékonyság) tanulói teljesítményekben, kompetenciákban mérhető pozitiv kimenetei (eredményesség) mindenkire kiterjednek (méltányosság), ami azt jelenti, hogy a társadalmi státusz alapvetően nem befolyásolja a tanulói teljesítmény-különbségeket. (Craw, 2015)

\section{Társadalmi és iskolai együttélési stratégiák}

Az esélyegyenlőség és méltányosság kérdéskörét a társadalmi csoportok együttélése során megvalósuló különböző stratégiákban is megvizsgálhatjuk. ${ }^{7}$ A stratégiák összességében akkulturációként értelmezhetök, vagyis egy adott csoportban megfigyelhető változások, melyek a huzamosabb ideig való együttélés során alakulnak ki. ${ }^{8}$ Látni fogjuk, hogy az egyes társadalmi stratégiákban az esélyegyenlőség biztosításának kettős megközelítése, a diverzitáshoz (sokszínűség) való viszonyulás, valamint a résztvevők döntéshozási lehetősége eltérő mértékben jelenik meg. (1. ábra)

1. ábra. A társadalmi együttélési stratégiák dimenziói és fejlődésének rendszere

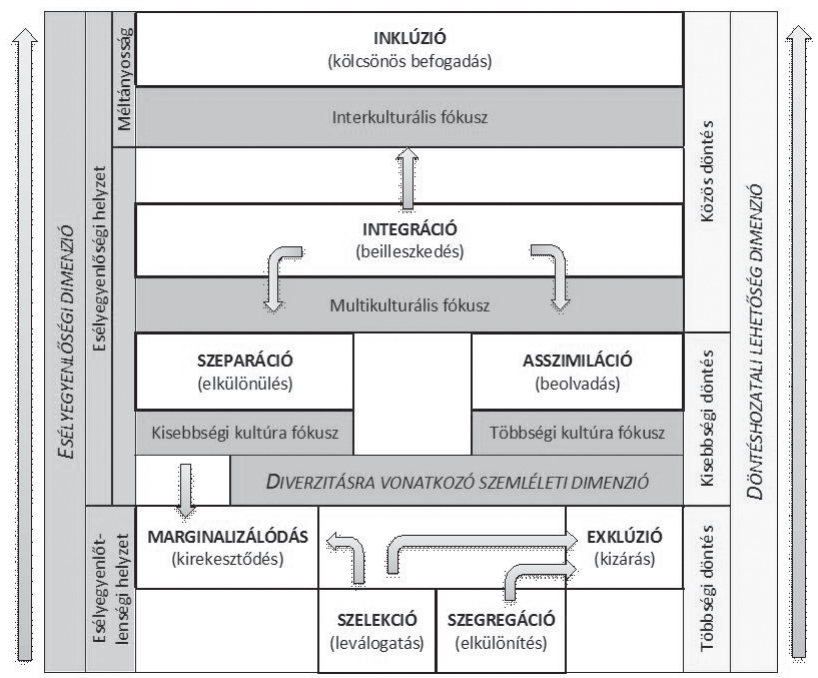


Az egyik legelterjedtebb és évszázadokig hangsúlyosan megjelenő stratégia az asszimiláció (beolvadás), mely úgy törekszik a különböző csoportokat beolvasztani a társadalom által preferált érték- és normarendszerbe, hogy a kulturális különbségeket az uralkodó kultúra hegemóniájával tünteti el. Ez a társadalmi stratégia elsősorban azon személyek és csoportok számára nyújt esélyeket, akik a társadalom által preferált kulturális vagy ideológiai sajátosságokat, szemléletet birtokolják, veszik át. Az asszimiláció esetén nem beszélhetünk valódi esélyteremtésről, mivel a megvalósuló társadalmi cselekvések nélkülözik a méltányosság alá sorolt, az egyéni és csoportsajátosságok figyelembevételére, megtartására irányuló jogokat. ${ }^{9}$ Az asszimilációs stratégia szélsőséges esetben kirekesztéshez (exclusion) ${ }^{10}$, illetve marginalizálódáshoz vezet azok esetében, akik nem tudnak vagy akarnak megfelelni a beolvasztó szemléletnek. A társadalom peremére kerülésnek (marginalizáció) reális lehetőségét rejtő uralkodó szemlélet - esetünkben az asszimiláció - szintén az esélyegyenlőség hiányát mutatja. (Varga, 2006)

Az asszimiláció mellett megjelenő másik stratégia a szegregáció, mely elsősorban nem az egyéni és csoportsajátosságok beolvadását célozza (bár esetenként azt is), hanem sokkal inkább az elkülönítést, a közös tértől való megfosztást, a homogén közösségi csoportokat tartja hatékony fejlesztési eszköznek. A szegregáción ${ }^{11}$ (elkülönítés) - egyéneknek vagy csoportoknak valamilyen vélt vagy valós tulajdonsága alapján történő elkülönítése a társadalom valamely szegmensében már önmagában is esélyegyenlőtlenségi helyzetet teremt, és így gátat szab minden további méltányossági cselekvésnek. ${ }^{12}$

A csoportok önkéntes elkülönülési folyamatát szeparációként (elkülönülés) értelmezzük, melynek hátterében az a belülröl jövő szándék áll, hogy az adott csoport a különállással képes legyen saját kultúráját, nyelvét, identitását minél nagyobb mértékben megörizni. ${ }^{13} \mathrm{Ez}$ az elkülönülés egyben válasz arra az esélyegyenlőtlenségi helyzetet teremtő társadalmi stratégiára, amely a kulturális színvakság (colorblind) „mindenki egyforma" elve mentén nem biztosítja a csoportidentitás megőrzésének jogát közös keretekben. (Arató, 2007)

Az éles csoporthatárok térbeli megjelenésének további 
formája a szelekció (leválogatás), mely a szegregáció „előszobájának" tekinthető, mivel eredményét tekintve sok hasonlóságot hordoz. A szelekció elsősorban az oktatási rendszerekben megfigyelhetö és sok esetben látens módon jelenik meg. ${ }^{14}$ (Lannert, 2003) Esélyegyenlőségi szempontból a szelekció hasonlít a szegregációhoz, hiszen a „válogatás” következtében létrejövő elkülönülés ugyanolyan élethelyzetet teremt a hozzáférés biztosítása és az attól való megfosztottság szempontjából. A látens szelekciós mechanizmusok különösen nehézzé teszik az esélyegyenlőségi beavatkozásokat, mivel explicit nem jelenik meg az elkülönítés, elkülönülés szándéka, így nehéz ellensúlyozó beavatkozásokat tervezni. (Bourdieu, 2003)

A felerősödött szelekciós mechanizmusokkal és szegregációs tendenciákkal szemben alakult ki az integráció (beilleszkedés) stratégiája, mely deklaráltan a különböző helyzetü személyek és csoportok együttélését célozza. Esélyegyenlőségi szempontból azonban az integrációt jelentő beilleszkedés magában hordozza, hogy van egy olyan uralkodó csoport, amelybe integrálódik egy másik egyén vagy csoport. Mindez könnyen vezethet az asszimiláció felé, mivel a beilleszkedők óhatatlanul is feladják sajátosságaikat vagy azok egy részét. $\mathrm{Az}$ integrációhoz sorolják ugyanis azt a fajta együttélést is, amikor a közös térben nem irányul méltányosság, figyelem valamenynyi - legtöbbször éppen az integrált - egyén vagy csoport igényére, melynek következtében szeparáció is kialakulhat. ${ }^{15}$

Napjainkban a társadalmi stratégiák közül az inklúzió az, amely az esélyegyenlőség és méltányosság szemléletére építve eredményes megoldásokat kínál. Az inklúzió (kölcsönös befogadás) a hátrányt okozó megkülönböztetés tilalmát a valódi hozzáférést biztositó méltányos és személyre szabott szolgáltatásokkal együtt alkalmazza annak érdekében, hogy a különböző csoportok és egyének sikeresen (esélyteremtő módon) együtt tudjanak élni. (Papp 2012; Asumah és Nagel, 2014; Varga, 2015a) 


\section{Iskolai sikerek és ami mögöttük van}

Az oktatási esélyegyenlőségre törekvés során figyelembe kell venni azokat az iskolai mechanizmusokat is, amelyekben az egyenlőtlenségi helyzetek gyökereznek. Az iskolarendszerben különböző mértékben megjelenő látens szelekciós mechanizmusok, illetve a tanulói „képességekben” mért eredményességek hátterében többek között a családok által birtokolt és az iskola által preferált tőkefajták (pénz- és szimbolikus: kulturális, társadalmi tőke) befektetésének különbsége húzódik. Ezáltal „az iskola a társadalmi egyenlőtlenségek újratermelődésének legitimált eszköze" (Bourdieu, 1978:281) lesz, mivel a különböző társadalmi helyzetű családok iskolához való viszonya (habitusa) mint kulturális tóke határozza meg az iskolába való pénzbeli és szimbolikus tőkék befektetésének mértékét. Amennyiben a család érték- és normarendszerében erőteljesen megjelenik a hosszú távú iskoláztatás igénye, akkor képes és hajlandó folyamatos befektetésre az iskoláztatás során. Ha a család történetében, kulturális tókéjében az iskoláztatás nem kiemelt szempont, ezek a beruházások elmaradnak. Ez azt jelenti, hogy nem tud élni az iskolaválasztás és az oktatási szolgáltatások széles körével, és gyermekét mielőbb a munkaerő-piaci kilépésre készíti fel. Bourdieu éppen erre a tényre hívja fel a figyelmet: manifeszt módon megjelenik az iskoláztatáshoz való egyenlő hozzáférés (esélyegyenlőség) a demokratikus társadalmakban, azonban látens módon a család kulturális tőkéje dönti el, hogy kíván-e, tud-e ezzel a lehetőséggel élni. Az esélyegyenlőség elve nyilvánvalóvá teszi az oktatási rendszerbe való belépés és előrehaladás lehetőségét, azonban méltányos (támogató) szolgáltatások nélkül főként a nagyobb - elsősorban kulturális - tőkékkel induló családok jutnak előnyös helyzetbe az iskolai előrehaladás során tett befektetéseikkel. A társadalmi közvélekedésben ez a mechanizmus úgy jelenik meg, hogy az iskoláztatás lehetősége mindenki előtt nyitott („esélyegyenlőség van”), és azok a családok a hibásak, amelyek nem élnek ezzel. Ez a megközelítés felfogható "az áldozat okolása” néven leírt mechanizmussal is (Ryan, 1974 id. Arató, 2012). Az egyenlőtlenségi rendszer újratermelődésének látensen múködő mechanizmusa így segíti a társa- 
dalmi pozíciók átörökítését, és egyben a felelősséget áthárítja a hátrányban lévő csoportra, amiért nem képes a mobilitás iskolán keresztüli csatornáit kihasználni. Mindezzel szemben csakis a folyamatosan múködtetett méltányosság tud hatni, mely többletráfordítással segíti a hátrányban levőket az esélykiegyenlítésben.

Nagy szerepet játszhat az az esélykiegyenlítésben a szociális tőke erősítése, vagyis az egyént körülvevő közösségekben a szociális erőforrások növelése (Coleman, 1997). A tőkefajták (gazdasági, kulturális, társadalmi) mint források elérhetőségét, elérését ugyanis fokozni lehet, ha az egyén szoros kapcsolatot alakít ki a különböző tőkefajták birtokosaival. A szociális tőke tetten érhető a szülö-gyermek kapcsolatban ${ }^{16}$ vagy a körülvevő közösség által közvetített értékek és normák rendszerében, illetve a szociális környezetének megbízhatóságában, hitelességében. A szociális tőke minél nagyobb mértékű megléte, illetve összehangolt és egymást erősítő jellege támogatóan hat az egyén sikeresen előrehaladására. (Messing, 2013)

Az iskola és a család kulturális különbségeire hívta fel a figyelmet az 1970-es évek amerikai polgárjogi mozgalmának időszakában alkotott „bikulturális szocializáció” rendszere, mely a szegregációt felszámoló és az integrációs helyzetekkel szembesülő iskolák tapasztalataira épített. Kiindulópontja, hogy a tanulók iskolai sikeressége érdekében figyelembe kell venni a családi szocializáció és az iskola viszonyrendszerét, valamint a két - eltérő kulturális elemeket közvetítő - tér közelítése érdekében tett szükséges beavatkozásokat, melyek összességében fedik le az Adler által megalkotott bikulturális szocializáció fogalmat. (Forray és Hegedüs, 1999) Az elmélet újszerüsége, hogy a családi (elsődleges) és az intézményes (másodlagos) térben történő szocializáció párhuzamos hatásrendszerére irányítja a figyelmet. Eszerint az iskolai eredményesség, majd a társadalmi integráció sikeressége elsősorban attól függ, hogy a kétféle szocializációs tér (családi és intézményes) között mekkora az átfedés. Az azonosságok és különbségek mibenlétét a terek kulturális összetevőiben lehet fellelni. Ez esetben a kultúra (habitus) magában foglalja az adott térre jellemző és állandónak tekinthető értékeket, normákat, szabályokat, mindezek objektivizálódott tárgyait, valamint az 
átörökítésük során használt szocializációs, nyelvi szocializációs formákat és a büntetési és jutalmazási rendszert. A bikulturális szocializáció kettős folyamatában a családi szocializáció kulturális jellemzőinek elsajátítása mellett megjelenik a közoktatás (óvoda, iskola) hatása, aholis a többségi társadalom kultúrája jelenti a szocializáció tartalmi elemeit. E kettősség kapcsán a bikulturális szocializáció elmélete egyértelműen kinyilvánítja, hogy vannak olyan családi szocializációk, melyek kulturális tartalma kis átfedést mutat az iskolára jellemző kulturális térrel. Ezt azonban mint megoldandó - az esélykiegyenlítést kívánó helyzetet kezeli: célul tűzi ki a két tér átfedésének szélesítését. A bikulturális mezőben résztvevők közös feladata a két eltérő tér kölcsönös megfeleltetése. Ebben a folyamatban a szociális tőkét jelentő egyik fontos szereplő a méltányos szolgáltatásokat nyújtó „mediátor”, aki az iskolai kulturális térben otthonosan mozgó személy (például pedagógus). A mediátor kölcsönhatásba lépve, megismerve az eltérő kultúrájú elsődleges szocializációs teret, képes abból elemeket átemelni az iskola világába, ezzel szélesítve az átfedést. A másik fontos szereplő a „transzlétor”, aki az iskolától eltérő kultúrájú elsődleges szocializációs térből érkezve már sikereket ért el a másodlagos (intézményi) szocializációs térben, és közössége számára képes kulturális elemeket közvetíteni az intézményi térből. Ezt hitelességéből adódóan teheti direkt közvetítéssel vagy észrevétlen mintaadással. Természetesen a bikulturális szocializáció kétirányú folyamata, a különböző kultúrák találkozása és kölcsönös megfeleltetése nem képzelhető el konfliktusok nélkül. Így az elmélet fontos része, hogy a bikulturális szocializáció sikerességének záloga a folyamatos és nyílt kommunikáció, valamint az együttmúködés - mely már az inkluzív társadalmi közösség szemlélete felé mutat.

\section{Inkluzív társadalom és nevelés összetevői}

A bikulturális szocializáció elmélete egyidőben született a multikulturalizmus mozgalmával, mely bizonyos szempontból az inkluzív társadalmi és iskolai szemlélet előzményének is tekinthető. A multikulturalizmus a világméretű mozgások eredményeként 
létrehozott egy új diskurzust, mely a társadalmi sokszínűség értékként elismerésére helyezi a hangsúlyt, központi elemévé téve a különböző kultúrák és identitások sikeres, egymást gazdagító együttélését és az ezzel kapcsolatos politikákat. A multikulturalizmus kiemeli a többkultúrájú társadalom esélyegyenlőség-szempontú kezelésének szükségességét, valamint az interkulturális pedagógia létjogosultságát, mely minden tanulóra kiterjedően kíván iskolai sikerességet biztosítani. (Banks, 1997; Feischmidt, 1997; Boreczky, 1999, 2014; Forray, Cs. Czachesz és Lesznyák, 2001; Torgyik, 2008; Kymlicka, 2012).

Az inklúzió - mely napjainkban merít a multikulturalizmus eszméjéből és gyakorlatából - történetiségének elején a fogyatékos gyermekek, tanulók sikeres intézményi nevelésének mikéntjére korlátozódott (Papp, 2012). Vagyis azt az integrativ (együttnevelö) óvodai, iskolai beavatkozást nevezték kizárólag inkluzívnak, amelynek során a környezet támogató módon alkalmazkodott az oda belépö, eltérő igényü gyerekekhez, tanulókhoz. (Csányi és Zsoldos 1994; Csányi és Perlusz 2001; Pető 2003; Kőpatakiné Mészáros 2004; Zászkaliczky, szerk. 2013; Duncan, 2014). Az inklúzió mint esélyegyenlőségi szempont érdekképviseletének fontos mérföldköve volt a Salamancai Nyilatkozat 1994-ben, mely az „Oktatást mindenkinek” („Education for All”) mozgalom ${ }^{17}$ részeként (folytatásaként) a sajátos nevelési igényű (special needs) tanulókra fókuszált, de már megnevezett más jellemzőjű tanulói csoportokat is.

Az inklúzió fogalmának tudományos és szakpolitikai megközelítése az utóbbi másfél évtizedben szerte a világon folyamatosan és több szempontból módosult. Az egyik változás, hogy jelentősen bővült a befogadás érdekében tett cselekvések fókuszában lévő személyek, csoportok köre. Ennek hátterében az a tapasztalat állt, hogy a környezet személyre szabott megváltoztatása nélkül a fogyatékossággal élők mellett más csoporto $^{18}$ is veszélyeztetettek a kirekesztési (exclusion) folyamatokban. Így a befogadást sikeresen támogató tevékenységek - pl. az iskolai lemorzsolódás megakadályozása vagy a hozzáférés korlátainak lebontása - egyre inkább kiterjednek minden olyan egyénre, csoportra, akik valamilyen okból gyakorta kizáródnak az oktatásból vagy a társadalom más szegmenséből. (Potts, 2002; Hinz, 2002; Asumah és Nagel, szerk. 2014) 
A célcsoport bővülése melletti további változás, hogy az inklúziót - az oktatási környezetből továbblépve - társadalmi szinten is egyre inkább fontos szemléletként értelmezik (social inclusion), ezzel felváltva és kiegészítve a társadalmi integráció fogalma alá sorolt megközelítést (Percy-Smith, szerk. 2000; Atkinson 2002; Kalocsainé Sánta és Varga 2005; Giambona és Vassallo 2013). A háttérben az az ezredfordulót jellemző útkeresés áll, amellyel Európa a különböző csoportok sikeres együttélését és erre építve a gazdasági fejlődés növekedését kívánta elérni. Az Európai Unióban szükségszerünek látták deklarálni a társadalmi kohézió fontosságát, így a „social inclusion” fogalmát jogi és stratégiai dokumentumokban a „Lisszaboni stratégia”"19 elindulása (2000) óta használják. Mindez tovább erősítette az inklúzió széles körű értelmezését és egyúttal hozzájárult a fogalomhasználat terjedéséhez is.

Az esélyegyenlőségi megközelítést megvalósulásának tartalmi elemeivel kiegészítve jutunk el ahhoz a szemléleti kerethez, melyet összefoglalóan inklúziónak (kölcsönös befogadás) nevezünk. Tovább bontva a fogalmat, elmondhatjuk, hogy az inklúzió egy olyan tudatosan müködtetett társadalmi hatásrendszer, mely az exklúzió (kizárás) ellentétes irányú folyamataként képes az egyének és csoportok kirekesztését, kirekesztődését meggátolni és a valódi értelemben vett hozzáférést biztosítani a társadalmi lehetőségekhez, javakhoz. Az inklúzió a kultúrák és közösségeknek kategorizálásmentes nézetén alapul, ahol a kölcsönös befogadás egy soha be nem fejeződö folyamat, állandó munka egy ideálért, amikor a társadalomban tapasztalható kizárási kényszerek eltünnek.

Az inklúzió társadalmi érvényesítésének egyik legfontosabb terepe az oktatás. Szemlélete szerint a befogadó társadalom alapvető forrása a közösség oktatásának, maga az oktatás pedig több mint az iskoláztatás - cselekvés a közösséggel, a közösségben, a közösségért. Az inkluzív nevelés egységes szemléletének és gyakorlati megvalósításának kialakításához járult hozzá az UNESCO 2005-ben kiadott irányelveivel. A dokumentum alapvetései között szerepel, hogy az inklúzió elfogadja a sokféleséget és nem korlátozódik a speciális nevelés reformjára. Továbbá nem csak a fogyatékos gyermekek javát szolgálja, hanem minden tanuló számára minőségi oktatási környezetet teremt, 
megszólítva többek között valamennyi peremhelyzetben lévő diákot. Ezzel nem csak egyes tanulókra fókuszál, hanem mindenki számára megteremti a tanulási folyamathoz való egyenlő hozzáférést. Az alapelveken túl a dokumentum négy dimenzióban ragadja meg az inkluzív nevelés lényegét. Kiemeli, hogy az inklúzió egy soha véget nem érő folyamat, mely az iskolai környezetben rejlő sokféleségre képes válaszokat keresni. Az inklúzió egyben törekszik a felmerülő akadályok azonosítására és felszámolására azzal, hogy információkat gyűjt, értékel és fejlesztéseket tervez a szakpolitika és a napi gyakorlat szintjén. ${ }^{20} \mathrm{Az}$ oktatási folyamatban az inklúzió jelenlétet (együttnevelést), részvételt (sikeres tanulási tapasztalatokat) és teljesítményt (mérhető eredményeket) hoz valamennyi tanuló számára. A negyedik dimenzióként az inklúzió hangsúlyozza, hogy a kirekesztéssel veszélyeztetett diákokra fokozott figyelmet fordít sikerességük biztosításával (UNESCO, 2005).

E gondolatkör folytatásaként az UNESCO 2009-ben kiadott egy ajánlást (UNESCO 2009a), mely felszólítja a tagállamokat, hogy fogadjanak el - a tervezést, a végrehajtást, az ellenőrzést és az értékelést is magában foglaló - befogadó oktatási megközelítést tartalmazó oktatáspolitikát, ezzel gyorsítva az „Education for All” megvalósítását, és ezzel hozzájárulva a befogadó társadalom kiépítéséhez. Megállapítják, hogy az inkluzív oktatás egyre szélesedő fogalma jelenti az általános vezérelvet ahhoz, hogy megerősítse az oktatást a fenntartható fejlődéshez és az élethosszig tartó tanuláshoz (life long learning) való egyenlő hozzáférés érdekében. Megközelítésükben leszögezik, hogy az inkluzív nevelés folyamatai arra irányulnak, hogy a minőségi oktatást biztosítsanak mindenkinek úgy, hogy közben tiszteletben tartják a sokszínúséget (diversity), figyelembe veszik a különböző igényeket (needs) és képességeket (abilities), valamint beépítik a diákok és közösségek jellemzőit és tanulási elvárásait, és egyben elutasítják a diszkrimináció minden formáját. E folyamat során a társadalmi igazságtalanságot és a szegénységet prioritásként kezelik, mivel ezek jelentős akadályokat gördítenek a befogadó oktatáspolitika és stratégiák megvalósítása elé, így ezen problémák megoldása jelentik a szektorközi együttmúködések kereteit. Megállapítják, hogy az inkluzív neveléshez „gyerekbarát” iskolai kultúrát és környe- 
zetet szükséges létrehozni ${ }^{21}$, amely elősegíti minden gyermek hatékony tanulását és befogadását, egyben egészséges és védelmet nyújt, figyelembe veszi a nemek sajátosságait, valamint ösztönzi a tanulók, családjuk és közösségeik aktív szerepét és részvételét. (UNESCO, 2009a:126) Az ajánlás a gyakorlati feladatokra is kitér: érinti a közpolitikákat, a rendszerszintű beavatkozásokat és kapcsolódásokat, a diákokra és tanárokra vonatkozó teendőket és a nemzetközi együttmúködésben rejlő lehetőségeket. Láthatóan létezik olyan - legitim szakmai dokumentum, mely az inkluzív nevelés szükségességét már tényként kezeli és a mielőbbi megvalósulását szorgalmazza javaslataival.

Az inkluzív nevelés alapvetése, hogy a kölcsönös befogadás nem csak oktatásszervezési keret, hanem a tanulási környezetbe való sokrétű tartalmi beavatkozás is (Corbett, 2001; Ainscow, 2004; Bárdossy, 2006; Rutkowski, Rutkowski és Engel, 2014). Éppen ezért az inkluzív pedagógia olyan rendszert feltételez, amely a tanulók közötti különbözőség felismerésével és értékelésével kezdődik, amely a diákot mint önálló személyiséget tekinti a maga komplexitásában - többek között társadalmi, kulturális és egyéni adottságai mentén. A személyes jellemzők végtelen variációiból kialakuló egyediségre, valamint a folyamatosan változó egyéni igényekre való reagálás igénye és sikeressége jelenti az inkluzív pedagógia lényegét. Az így a kialakított új szemléletü iskola a napi gyakorlatában az általa közvetített tananyagtartalommal, valamint tanítási módokkal folyamatosan alkalmazkodik diákjaihoz. Egyúttal épít az oda járó diákok identitására, tapasztalataira, tudására, képességeire, valamint bevonja a társadalmi környezetben fellelhetö partnereket. Képes a folyamatos megújulásra, mert belátja, hogy e nélkül nem tud eredményesen reagálni a változó igényekre.

\section{Korai iskolaelhagyás kontra reziliencia}

A jogi szabályozókban és a pedagógiai diskurzusban a „mit akarunk elérni" kérdésre adott válaszok között megjelenik a „mindenki számára méltányos iskoláztatást”. A „hogyan kí- 
vánjuk megvalósítani" kérdésre született megoldási javaslatok kapcsolódnak, illetve besorolhatók az inklúzió rendszerébe.

Az elmúlt években a „mit” és „hogyan” kérdéskör megválaszolására született az EU 2020 stratégia részeként az a megközelítés, mely a korai iskolaelhagyás ${ }^{22}$ problémakörét emelte fókuszba, és annak megakadályozására vár el célorientált helyzetértékelést, valamint oktatáspolitikai és gyakorlati eszközöket. (Az Európai Unió Tanácsa ajánlása..., 2011) Mindez azt jelzi, hogy az uniós társadalompolitika az inklúzió szemléletének és gyakorlatának eredményeit kívánja az egyes országokban mielőbb és mérhető módon látni - rendszerszintű tervezéssel és konkrét beavatkozásokkal. ${ }^{23}$ Minél inkluzívabb a társadalom és az iskola, annál inkább prevenciós, mintsem probléma-megoldási tevékenységek szabnak gátat a korai iskolaelhagyásnak. Így a korai iskolaelhagyás kérdésköre erőteljesen összefügg azzal, hogy milyen mértékben sikerül a befogadó iskolai (és társadalmi) környezetet kialakítani, fenntartani. ${ }^{24}$

Az esélykülönbségeket feltáró oktatáskutatásban az utóbbi évek során előtérbe került a pszichológia tudományterületén használt megközelítés, a rezilienciavizsgálat, mely azt tárja fel, hogy a hátrányos feltételek ellenére jól teljesítő egyének, csoportok, intézmények minek köszönhetik sikereiket. (Masten, 2001,; Masten és Wright 2010; Ceglédi 2012) A vizsgálatok sorra bizonyítják, hogy az egyén sikeres megküzdési képessége, 'lelki rugalmassága' (reziliencia) és a közösség kölcsönös befogadása során megvalósuló cselekvései (inklúzió) egymásra ható, elválaszthatatlan egységet alkotnak - az iskola világában különösen. Az inkluzív nézőpont és gyakorlat nem csak képes, de elengedhetetlen is a „sorsfordító” hatás kifejtéséhez, a hátránnyal küzdők rezilienciájának kiteljesedéséhez. Éppen ezért van kiemelkedő jelentősége annak, hogy az iskolai pályafutás során hátránnyal haladókat minél fejlettebb inkluzív intézményi környezet vegye körül. E nélkül a reziliencia rendkívül esetlegesen vagy egyáltalán nem alakul ki. A reziliencia témaköre - pszichológia világából kilépve - éppen arra irányítja a figyelmet, hogy van lehetőség - akár egyéni, akár csoportszinten - a „bejósolt” korlátok áttörésére, azonban a belső megküzdési képesség kialakítása egyértelműen igényel külső támogatást. (Raýman és Varga, 2015) 


\section{Röviden az inklúzió rendszerelvű modelljéről}

Az inklúzió társadalmi elvárása tervezett és célzott cselekvésekkel adott pontokon megközelíthető, azonban fenntartása egy soha véget nem érő folyamat, a kölcsönös befogadás érdekében tett egymásra épülő beavatkozások sora. Az inklúzió felé közelítéshez éppen ezért szükséges az egyes rendszerszakaszok - bemenet, folyamat, kimenet - azon kritériumainak meghatározása, melyek az inkluzivitás alapfeltételeit és folyamatos fejlesztését biztosítják. A kritériumrendszer modellként értelmezése egyben alkalmas arra, hogy a befogadás mértékének vizsgálatát is szolgálja, ezzel segítve a fejlesztési folyamatokat. (Varga, 2014)

\section{Bemenet - esélyegyenlöségi és méltányossági kritériumok}

Az inkluzivitás bemeneti kritériuma akkor teljesül, ha igazolható, hogy a vizsgált területre történő bevonás során minden személyre kiterjedően egyaránt érvényesültek az egyenlő bánásmód és a méltányosság szempontjai. Kiemelt figyelem és cselekvés irányult az integrált környezet létrehozására, valamint a szelekciós és szegregációs helyzetek felszámolására. Az esélyegyenlőségi szempontok további bizonyítéka, hogy az integrált környezetbe személyre szabott szolgáltatások segítségével jutottak be az abban résztvevők. Nem hiányoztak azok a támogató cselekvések, melyek nélkül valaki kizáródott volna.

\section{Folyamat - az inklúziót célzó rendszermüködtetési feltételek}

Az inklúzió folyamatának és feltételeinek számba vételéhez különböző modelleket vettünk alapul. Az USA felsőoktatásában elterjedt „Inclusive Excellence” fogalom adaptációja azt jelzi, hogy a kiváló teljesítménynek összhangban kell lennie a folyamat során a befogadásra irányuló erőfeszítésekkel. (Milem és mtsai, 2005) A befogadó szemlélet prioritása az „Inxlúziós Index"-et megalkotó angliai kutatóktól került beemelésre a rendszerbe. (Booth és Ainscow, 2002) A sokféle tárgyi és pedagógiai feltétel pedig a Magyarországon 2003-ban bevezetett Integrációs Pedagógiai Rendszer (IPR) elemeiből szemezge- 
tett. (Arató és Varga, 2012) Az inkluzív környezet kritériumainak áttekintéséhez mindezekre építve, ezt kiegészítve határoztuk meg az adott környezetben megjelenő diverzitás (Dezső, 2014) sikeres kezeléséhez szükséges feltételeket, melynek az általunk alkotott modellben 6 eleme van.

1. A sokszínüséget tükröző tér és tárgyi környezet megjelenésén keresztül kézzel fogható értékrendet közvetít, amenynyiben a nyitottságot és sokszínúséget tükrözi, érzékeltetve valamennyi alkotójának értékeit és elvárásait.

2. A sokszínüség értékelésének szemlélete az inklúzió sarokköve, mely a befogadási folyamat minden szintjét és szereplőjét át kell, hogy hassa. A szemlélet a közös térben lévők pozitív attitűdjében érhető tetten, háttérbe szorítva a negatív sztereotípiákat.

3. A megvalósítók felkészültsége biztosítja, hogy az inkluzív szemlélet gyakorlatba ültetéséhez elengedhetetlenül szükséges cselekvések eredményesek legyenek. A pedagógiai módszertani gazdagság napi használata garantálhatja a diverzitás sikeres kezelését.

4. Az intézményi pedagógiai szolgáltatások körébe az egyéni tanulói utak megértése, segítése, valamint a személyre szabott tartalmak és cselekvések tartoznak. Komplex pedagógiai szolgáltatásrendszer képes eredményesen reagálni az adott térbe bekapcsolódók különbözőségeire.

5. Az együttmüködés és partnerség szempontja az inkluzív téren belüli és kívüli személyek, csoportok és intézmények közös cselekvésének fontosságát hangsúlyozza.

6. A sokféleség kihívásából eredő folyamatos megújulás a befogadó környezet kialakításának feltétele. Jellemzője, hogy nem egyszeri beavatkozásként, hanem folyamatos méréssel, értékeléssel kísért megújításként értelmezi az inkluzivitásra törekvést.

\section{Kimenet - valamennyi résztvevöre érvényes eredményességi mutatók}

Egy inkluzívvá váló intézmény esetén a vizsgálódás a bemenet (esélyegyenlőségi szempontok érvényesülése), a folyamat 
(a fejlesztés során tett beavatkozások) és a kimenet (intézményi funkció teljesülése) területein egyaránt szükséges. Az egyes területeken mért eredményekben akkor jelenik meg az inkluzivitás szempontja is, ha a kapott értékek a közös térben lévők mindegyikére egyformán érvényesek. Természetesen a helyi mutatók önmagukban még nem jelzik a befogadás valódi sikerességét, fontos az intézményi adatok összevetése a makroszintű (országos, nemzetközi) létező vagy elvárt eredményekkel is. Ilyen adatok lehetnek a korai iskolaelhagyásra vagy a rezilienciára vonatkozó mutatók.

\section{Összegzés}

Az esélyegyenlőség és méltányosság biztosítását mint jogi követelményt és szemléleti alapot tekintettük a tanulmányban kiindulópontnak. Ez alapján vizsgáltuk a társadalomban megmutatkozó együttélési stratégiákat és tértünk ki néhány iskolai mechanizmusra. Így jutottunk el az inklúzió társadalomfilozófiai megközelítéséig, melynek gyakorlatba ültetéséhez napjainkban a jogi garancia és a modell-leírás egyaránt rendelkezésre áll.

Az 1. számú ábrán rendszerben tekinthettük át a társadalmi stratégiákat; az inkluzivitás felé vezető út multidimenzionális megközelítését. Láthattuk, hogy a különböző társadalmi stratégiák eltérnek abból a szempontból, hogy esélyegyenlőtlenségi helyzetet teremtenek (szegregáció, szelekció), vagy képesek az esélyegyenlőséget bizonyos szempontból (asszimiláció, szeparáció, integráció), illetve azon túl is (inklúzió) biztosítani. Azt is megfigyelhettük, hogy az egyes stratégiák esetén a többség és a kisebbség döntéshozási lehetősége és diverzitáshoz füződő viszonya különbözik. Az összefüggések - az ábrában nyilakkal jelölve - megmutatták a stratégiák lehetséges kimeneteit, valamint fejlődési irányát is. Így a szegregáció/szelekció, de akár a szeparáció is könnyen vezethet marginalizálódáshoz vagy kizáráshoz, míg az integráció magában rejti az asszimilálódás vagy a szeparálódás veszélyét, és csak méltányos szolgáltatásokkal kiegészítve biztosítja az inklúziót.

A két végponton elhelyezkedő stratégia - elkülönítés és kölcsönös befogadás - között többféle társadalmi együttélési 
lehetőség körvonalazódik. A stratégiák közül - társadalmi és iskolai szempontból egyaránt - az inklúziót tekintjük a legsikeresebbnek, amely a kölcsönös befogadásra vonatkozó közös döntésen alapul, értékként épít az egymással kapcsolatba kerülő diverzitásra és a méltányosság eszközrendszerével valódi esélyegyenlőséget képes biztosítani.

\section{Jegyzetek}

1 A tanulmányban olvasható témát jóval részletesebben, nemzetközi kontextusba helyezve és hazai példákkal kiegészítve jelentettük meg Az Inklúzió szemlélete és gyakorlata címú kötetben (Varga, 2015a).

2 Az esélyegyenlőtlenséghez kapcsolódó alapfogalmakat és társadalmi mechanizmusokat az elnyomás formái alapján is értelmezhetjük. Napjaink értelmezése szerint a strukturális elnyomás kevésbé direkt és látványos, a mindennapi élet folyamatainak következményeként jelentkezik. Vagyis a strukturális elnyomás társadalmi igazságtalanságokat jelent, amelyeket bizonyos csoport tagjai szenvednek el annak következtében, hogy a gazdasági, politikai és kulturális intézmények az igazságtalanságból következő egyenlőtlenségeket újratermelik. A strukturális elnyomás csoportokhoz kötődő fogalom, mivel az egyén az adott csoportba tartozása miatt szenved igazságtalanságot. (Young, 2014).

3 A magyarországi jogszabály az egyenlő bánásmód mellett a méltányos cselekvéseket is hangsúlyozza, megnevezve azokat a személyeket, csoportokat, melyekre kiemelt figyelmet kell az esélyegyenlőség szempontjából fordítani.

4 E csoportok magyarországi helyzetéről készült kötetben összefoglaló írást olvashatunk az őket sújtó előítéletekről (Bigazzi, 2013), valamint a hazai jogszabályokban és stratégiákban való nevesített megjelenésükről (Orbán, 2013a, 2013b), továbbá statisztikai adatokra támaszkodó helyzetleírásokban megismerkedhetünk azzal az öt kiemelt csoporttal - mélyszegénységben élők és cigányok/romák (Cserti Csapó és Orsós, 2013), gyerekek (Szemenyei és Végh, 2013), nők (Kokas és Lakatos, 2013a), idősek (Kokas és Lakatos, 2013b), fogyatékossággal élők (Horváth, 2013).

5 Részletes információk olvashatók a vizsgálatokról az OECD honlapján. http://www.oecd.org/pisa/ (2015.06.26.) 
2007-ben a PISA-vizsgálatokon legsikeresebben teljesítő országok oktatási rendszerét vizsgálva azt találták, hogy a közös pont közöttük a kiváló pedagógusok voltak, illetve, hogy minden tanulót sikerrel vontak be az oktatási folyamatokba. (Barber és Moushed, 2007)

7 A többség és kisebbség együttélésének különböző formáit nevezi Kozma Tamás együttélési stratégiának, mely során a többség (vagy uralkodó csoport) határozza meg a kisebbség (vagy elnyomott csoport) számára azt az utat, amelyet elvár. Az együttélő csoportok valamely nemzeti közösség tagjai, sajátos kulturális jellemzőkkel. (Kozma, 1993)

8 Az akkulturáció fogalomköre alapvetően a különböző kulturális csoportok közötti viszonyrendszert fedi le. Erre alkotott elméletet Berry, aki több szempont (két-két szempontból áttekintett 4 stratégia) szerint helyezte el a stratégiákat. A szempontok a „kulturális örökség és identitás fenntartása”, illetve a „,kapcsolat a másik csoporttal”, valamint a „kisebbségi csoport stratégiája”, illetve a "társadalom elvárása”. Valamennyi szempontnál pozitív és negatív pontokon helyezte el a stratégiákat. Pozitiv ponton jelenik meg a kisebbség integrációja, melyet a társadalom multikulturalizmusa övez. Negatívként értékeli a marginalizálódást, mely a társadalom kizárási folyamatának eredménye, illetve az asszimilációt a melting pot (olvasztótégely) stratégia mentén. Köztes helyzetként jelöli a kisebbségi csoport szeparációját, illetve a többség szegregációs nyomását. (Berry, 2005:705)

9 Különböző mértékű asszimilációs stratégia jellemezte például a magyarországi viszonyokat 1949-től a rendszerváltásig. Ez erősen hozzájárult többek között a különböző nemzetiségek nyelvcsere folyamatának felgyorsulásához. (Orsós, 2012). Mindez kiegészült egy erős politikai-ideológiai szemlélettel, mely az iskolarendszerben a „szocialista embertípus fejlesztését” célozta az internacionalista iskolai stratégia mentén. (Kozma, 1993)

10 Kutatásokkal igazolt, hogy a két esélyegyenlőtlenségben (pl. etnikai, gender- és osztályhelyzet) lévő csoporthoz való egyidejű tartozás egymást erősítő társadalmi hátrányt okoz. (Neményi, 2013) Ezt a helyzetet az interszekcionalitás fogalomával jelölik. (Vincze, 2012)

11 A szegregáció iskolai hátrányaira Magyarországon a roma/cigány tanulók iskolai sikertelenségeivel összefüggésben hívták fel a kutatók a figyelmet. Az első írások között van Réger Zita tanulmánya, mely a nyelvi felzárkóztatás érdekében létrehozott homogén „cigányosztályok" sikertelenségét emelte ki, hangsúlyozva, hogy az elkülönítés minden szempontból (tanári ellá- 
tottság, tárgyi feltételek, pedagógiai tartalom stb.) rosszabb feltételeket hozott magával. (Réger, 1978) Hasonló megállapításra jutottak az ezredforduló környékén végzett vizsgálatok kutatói (Havas, Kemény és Liskó, 2002; Havas és Liskó, 2004), melyekre alapozva indultak a hazai integrációs programok 2002-ben. (Németh és Papp, 2006)

12 Több friss kutatás is a szegregáció erősödéséről számol be az oktatásban (Kertesi és Kézdi 2009, 2014; Varga J. szerk., 2015). A szegregatív-szelektív oktatás az egyik okozója annak, hogy Magyarországnak a nemzetközi mezőnyben sem sikerült az első PISA-vizsgálatok (2000) óta igazán előre lépni azon országok felé (OECD 2013), melyek képesek az oktatási rendszer segítségével a családi háttértényezőkből adódó esélykülönbségeket minőségi oktatási környezettel ellensúlyozni, az elmaradásokat enyhíteni.

13 A magyarországi iskolarendszerben a nemzetiségi oktatás az, amely a szeparációs stratégia mentén szerveződik. Ezekben az intézményekben a szülők kérésére vesznek részt a diákok anyanyelvi oktatásban és őrizhetik az identitásukat a népismerethez kötődő tananyagtartalmakkal. (Forray, 1998; Forray és Hegedüs, 2003)

14 A nevelésszociológia széles irodalommal rendelkezik arra vonatkozóan, hogy miféle mechanizmusok mentén történik a leválogatás az oktatási rendszerben. (Meleg, szerk. 2003) „Képesség” szerinti leválogatás az egyik legszembetúnőbb forma, mely iskolák között és iskolán belül (pl. tagozatos oktatás) is előnyösebb helyzetet teremt azok számára, akik az iskola által preferált tőkefajták birtokosai (Douglas, 2003; Bourdieu, 2003), sok esetben észrevétlenül.

15 Ezt a jelenséget az oktatásban különösen a fogyatékossággal élő tanulókra vonatkozóan figyelték meg és „rideg integráció” fogalommal jelölik. Az integráció ezen formája a különbségekből adódó hátrányokat felerősíti (Réthy E.-né 2002, 2004, 2013), és könnyen vezethet a marginalizálódáshoz, hiszen a közös térben egyenlőtlen helyzetben lévők méltányos cselekvések nélkül kiszorulnak a javakból.

16 A szociális tőke hiánya különösen sújtja a család nélkül, gyermekvédelmi gondoskodásban felnőtt fiatalokat, és egyik fontos okozója iskolai sikertelenségüknek. (Veressné Gönczi, 2004; Homoki, 2014)

17 A mozgalom kiindulópontja, az UNESCO által 1990-ben kiadott „Jomtien” nyilatkozat tartalmazza azokat az alapvetéseket, melyeket a nagy jelentőségű, később született irányelvek 
(Salamancai Nyilatkozat 2004, UNESCO, 2005, 2009a) fejlesztettek tovább az inklúzió megvalósítása érdekében.

18 Iskolai szempontból az inklúzió szempontjából fókuszba emelt csoportok között találhatjuk többek között a szociálisan hátrányos helyzetű, a nemzeti-etnikai kisebbséghez tartozó, a migráns, valamint a fogyatékossággal élő tanulókat.

19 Az Európai Unió tagállamainak vezetői fogadták el az első Liszszaboni Stratégiát azzal a céllal, hogy 2010-re az Európai Unió a világ legversenyképesebb térségévé váljon. A célok között kiemelt szerepet kapott a társadalmi kohézió megteremtése a társadalmi befogadás növelésével. A 2010-ben megújított stratégia - az általános célokat megtartva - célként túzte ki többek között a korai iskolaelhagyás csökkentését, az iskolai végzettség növelését és a szegénység visszaszorítását. (http://ec.europa. eu/europe2020/index_hu.htm 2015. 06. 22.)

20 Az inkluzivitás oktatási érvényesítésének sajátos terepe a felsőoktatás, ahol az Inclusive Excellence (Inkluzív Kiválóság) új fogalma a sokszínűség, méltányosság, befogadás, kiválóság mint négy alappillér tartalmi egybefonódását jeleníti meg. (AACU, 2005, 2013) A fogalom azt hangsúlyozza, hogy a sokszínűség és a kiválóság elválaszthatatlanok. Nyitott és befogadó szemléletet közvetít, melyre alapozva a kulturális, szociális kompetencia magas foka tud kialakulni - felvértezve mindenkit egymás megértésére és a kölcsönös elfogadásra -, mely kompetenciákat aztán haszonnal tudnak alkalmazni a résztvevők az egyetemi éveken túl is. Az Inclusive Excellence sajátossága, hogy a megvalósulásához intézményi szinten több szempontú tartalmi és strukturális beavatkozás szükséges. (Milem és mtsai, 2005; Williams és mtsai, 2005; Bauman és mtsai, 2005).

21 Napjaink irodalma a sikeresen múködő sokszínű tanulási környezet (Diverse Learning Environments) kialakításának és múködtetésének szükségességét hangsúlyozza (Hurtado és mtsai, 1999, 2012). Ez a szemlélet nem megoldandó problémaként tekint a heterogén csoportra, hanem felismeri a benne rejlő lehetőségeket és azok kiaknázását célozza. Ezt a környezet teljes körű átalakításával - „barátságossá tételével” - kívánja elérni, ahol a sokszínúség értéket és helyet kap a mindennapokban, ezzel fejlesztve valamennyi résztvevőt. Nem vitatja azonban, hogy a heterogén összetételű osztálytermi párbeszéd során sokféle nehézséggel kell szembenézni, és ehhez kulturális érzékenységgel és szociális kompetenciákkal szükséges felvérteződnie a tanároknak és a diákoknak, mely kompetenciák az iskolán túli életükben is hasznosak lesznek (Young és Davis-Russel, 2014). 
22 „A korai iskolaelhagyás rátája az Európai Unióban hivatalosan használt definíció szerint azon 18-24 évesek arányát méri, akiknek (még) nincsen középfokú (ISCED 3 szintű, szakmunkás vagy érettségi típusú) végzettsége, és nem is vesznek részt oktatásban vagy képzésben." (A végzettség nélküli korai iskolaelhagyás... 2013:3.)

23 A magyarországi helyzetképről több értékes tanulmány olvasható. (Herczog, 2013; Imre, 2014; Lannert, 2014; Mártonfi, 2014)

24 2014-ben valósult meg az az országos kutatás, amely a szociálisan hátrányos helyzetű és roma/cigány diákokat is nevelő iskolákat vizsgálta tanulóik sikerességéből kiindulva. A vizsgálat eredményeképp láthatóvá vált, hogy ha az intézmény nem szegregálódott térségben, településen helyezkedik el, akkor diákjainak tanulmányi előrehaladása - társadalmi helyzettől függetlenül - annál sikeresebb, minél befogadóbb az iskolai környezet. (Varga, 2015b)

\section{Irodalomjegyzék}

\section{Hivatkozott jogszabályok és stratégiai dokumentumok}

2003. évi CXXV. törvény az egyenlő bánásmódról és az esélyegyenlőség előmozdításáról

AACU (2005): Making excellence inclusive series. Association of American Colleges and Universities - Washington, DC. 2005. http://www.aacu.org/programs-partnerships/ making-excellence-inclusive [2014. 11. 10.]

AACU (2013): Board statement on diversity, equity, and Inclusive Excellence. Association of American Colleges and Universities - Washington, DC. 2013. http://www.aacu. org/about/statements/2013/diversity [2014. 11. 10.]

A végzettség nélküli korai iskolaelhagyás ellenes középtávú stratégia. http://www.kormany.hu/download/5/fe/20000/ V\%C3\%A9gzetts\%C3\%A9g\%20n\%C3\%A9lk\%C3\%BCli\%20 iskolaelhagy\%C3\%A1s\%20.pdf [2015. 04. 10.]

Az Európai Unió Tanácsa ajánlása a korai iskolaelhagyás csökkentését célzó szakpolitikákról (2011/C 191/01) http:// eur-lex.europa.eu/LexUriServ/LexUriServ.do?uri=OJ:C:2 011:191:0001:0006:HU:PDF [2015. 04. 10.]

Európai Unió Alapjogi Ügynöksége - Európa Tanács (2011): 
Kézikönyv az európai megkülönböztetés-mentességi jogról. Az Európai Unió Kiadóhivatala, Luxembourg.

OECD (2013): PISA 2012 Results: Excellence Through Equity. Giving Every Student the Chance to Succeed (Volume II). PISA, OECD Publishing. http://www.mecd.gob.es/dctm/ inee/internacional/pisa2012/pisa2012voliiinternacional. pdf?documentld=0901e72b8178af64 [2014. 10. 11.]

Presidency Conclusions - Lisbon European Council, 23 - 24

March 2000. http://www.europarl.europa.eu/summits/ lis1_en.htm [2014. 10. 19.]

UNESCO (1994): Salamanca Statement and Framework for Action on Special Needs Education. Salamanca, Spain, 7-10 June 1994.

UNESCO (2005): Guidelines for Inclusion: Ensuring Access to Education for All, UNESCO, Paris.

UNESCO (2009a): Policy Guidelines on Inclusion in Education. United Nations Educational, Scientific and Cultural Organization. Paris.

UNESCO (2009b): Defining an Inclusive Education Agenda: Reflections around the 48th Session of InternationalCenference on Education. Geneva: UNESCO IBE

\section{Hivatkozott irodalom}

Ainscow, M. (2004): Developing inclusive education system: what are the levers for change? Journal Educational Change, 2004/6, 10, 2- 16.

Arató Ferenc és Varga Aranka (2012): Intézményfejlesztési útmutató a differenciált, IPR alapú fejlesztések megvalósításához. Közigazgatási és Igazságügyi Hivatal, Budapest.

Arató Ferenc (2007): Pozitív diszkrimináció vagy megerősítő társadalmi törekvések? Új Pedagógiai Szemle, május

Arató Ferenc (2012): Rejtett sztereotípiák az egyetemi hallgatók körében. In: Orsós A. és Trendl F. (szerk.) Útjelzők. Pécsi Tudományegyetem BTK, Pécs, 24-32.

Asumah, S. N. és Nagel, M. (2014): Preface. In: Asumah, S. N. Nagel, M. (szerk.) Diversity, Social Justice, and Inclusive Excellence - Transdisciplinary and Global Perspectives. State University of New York Press, Albany, New York, USA, 9-13. 
Atkinson, A. B. (2002): Social inclusion and the European Union. Journal of Common Market Studies, 40, 4, 625-643.

Banks, J. A. (1997): Multicultural Education: Characteristics and Goals. In: Banks, J. A., Banks, Ch. A. és McGee (szerk.) Multicultural Education: Issues and Perspectives. Allyn and Bacon, Boston, USA, 3-31.

Barber, M. és Mourshed, M. (2007): Mi áll a világ legsikeresebb iskolai rendszerei teljesítményének hátterében? McKinsey \& Company, New York, USA. http://mek.oszk. hu/09500/09575/09575.pdf [2014. 10. 10.]

Bárdossy Ildikó (2006): A befogadó iskola és környezete. Új Pedagógiai Szemle, 56, 3, 35-45.

Bauman, G., Bustillos, L. T., Bensimon, E. M., Brown, Ch. és Bartee, R., D. (2005): Achieving Equitable Educational Outcomes with All Students: The Institution's Roles and Responsibilities. Association of American Colleges and Universities, Washington D.C., USA.

Berry J. W. (2005): Acculturation: Living successfully in two cultures. International Journal of Intercultural Relations, 29, 697-712.

Bigazzi Sára (2013): Előítélet. In: Varga A. (szerk.) Esélyegyenlőség a mai Magyarországon. Pécsi Tudományegyetem BTK NTI Romológia és Nevelésszociológia Tanszék, Pécs, 15-36.

Booth, T. és Ainscow, M. (2002, 3rd edition 2011): Index for Inclusion: developing learning and participation in schools, revised edition. Centre for Studies on Inclusive Education, Bristol, UK.

Boreczky Ágnes (1999): Multikulturális pedagógia - új pedagógia? Új Pedagógiai Szemle, 43, 4, 26-38.

Boreczky Ágnes (2014): Multikulturalizmus-multikulturális pedagógia., In: Gordon Győri J. (szerk.) Tanárok interkulturális nézetei és azok hatása az osztálytermi munkára: $A$ multikulturális és interkulturális szemlélet elméleti alapjai és történeti vonatkozásai az oktatásban. ELTE Eötvös Kiadó, Budapest, 21-35.

Bourdieu, P. (1997): Gazdasági tőke, kulturális tőke, társadalmi tőke. In: Angelusz R. (szerk.) A társadalmi rétegződés komponensei. Budapest, Új Mandátum Kiadó, 156-177. 
Bourdieu, P. (2003): Az iskolai kiválóság és a francia oktatási rendszer értékei. In: Meleg Cs. (szerk.) Iskola és Társadalom. Szöveggyűjtemény. Dialóg Campus, Budapest-Pécs.

Bourdieu, P. (1978): A társadalmi egyenlőtlenségek újratermelődése. Gondolat Kiadó, Budapest, 268-311.

Ceglédi Tímea (2012): Reziliens életutak, avagy a hátrányok ellenére sikeresen kibontakozó iskolai karrier. Szociológiai Szemle, 22, 2, 85-110.

Coleman, J. S. (1997): Család, iskola, szociális tőke. In: Kozma T. (szerk.) Oktatás és társadalom. Kossuth Egyetemi Kiadó, Debrecen, 152-156.

Craw, J. (2015): Statistic of the Month: Education Performance, Equity and Efficiency. http://www.ncee.org/2015/01/statistic-of-the-month-education-performance-equity-andefficiency/ (letöltés ideje: 2015. 02. 03.)

Csányi Yvonne és Perlusz Andrea (2001): Integrált nevelés - inkluzív iskola. In: Báthory Z. és Falus I. (szerk.) Tanulmányok a neveléstudomány köréből. Osiris, Budapest, 314-332.

Csányi Yvonne és Zsoldos Márta (1994): Világkonferencia a speciális szükségletűek neveléséről. Új Pedagógiai Szemle, 44, 12, 41-50.

Cserti Csapó Tibor és Orsós Anna (2013): A mélyszegénységben élők és a cigányok/romák helyzete, esélyegyenlősége. In: Varga A. (szerk.) Esélyegyenlöség a mai Magyarországon. Pécsi Tudományegyetem BTK NTI Romológia és Nevelésszociológia Tanszék, Pécs, 99-120.

Dezső Renáta Anna (2014): A diverzitás lehetséges elméleti keretei a neveléstudományokban. Autonómia és Felelősség, 1, 32-44.

Douglas, J. W. B. (2003): A tanulók képességek szerinti elosztása. In: Meleg Cs. (szerk.) Iskola és Társadalom. Szöveggyűjtemény. Dialóg Campus, Budapest-Pécs, 2003.

Duncan, J.M. (2014): Understanding Disability Rights in a Global Context. In: Asumah, S. N. és Nagel, M. (szerk.) Diversity, Social Justice, and Inclusive Excellence - Transdisciplinary and Global Perspectives. State University of New York Press, Albany, New York, USA, 363-378.

Feischmidt Margit (1997): Multikulturalizmus: kultúra, iden- 
titás és politika új diskurzusa. In: Feischmidt M. (szerk.) Multikulturalizmus. Osiris Kiadó, Budapest, 7-29.

Forray R. Katalin, Cs. Czachesz Erzsébet és Lesznyák Márta (2001): Multikulturális társadalom - interkulturális nevelés. In: Báthori Z. és Falus I. (szerk.): Tanulmányok a neveléstudomány köréböl. Osiris Kiadó, Budapest.

Forray R. Katalin és Hegedüs T. András (2003): Cigányok, iskola, oktatáspolitika. Oktatáskutató Intézet - Új Mandátum Könyvkiadó, Budapest.

Forray R. Katalin - Hegedüs T. András (1999): Cigány gyerekek szocializációja. Aula, Budapest, 28-33.

Forray R. Katalin (1998): Nemzetiségek, kisebbségek. Educatio, 7, 1, 50-66.

Giambona, F. és Vassallo, E. (2013): Composite Indicator of Social Inclusion for European Countries. Springer Science, Business Media, Dordrecht, Netherlands, 269-293.

Havas Gábor, Kemény István és Liskó Ilona (2002): Cigány gyerekek az általános iskolában. Oktatáskutató Intézet - Új Mandátum Kiadó, Budapest.

Havas Gábor és Liskó Ilona (2004): Szegregáció a roma tanulók általános iskolai oktatásában. Kutatási záró tanulmány. (Kutatás Közben 266.) Oktatási Minisztérium - Felsőoktatási Kutatóintézet, Budapest.

Herczog Mária (2013): Szakellátásban élő gyerekek és a korai iskolaelhagyás. Tempus Közalapítvány, Budapest. 13. http://ok.proa.hu/documents/Projektek/2013/QALL/ qall_szakellatas_esl_herczog_maria.pdf [2015. 04. 10.]

Hinz, Andreas (2002): Von der Integration zur Inklusion - terminologisches Spiel oder konzeptionelle Weiterentwicklung. Zeitschrift für Heilpädagogik, 53, 9, 354-361.

Hirschmann, Nancy J. (2014): Gender and the Politics of Invisible Disability. In: Asumah, S. N. - Nagel, M. (szerk.) Diversity, Social Justice, and Inclusive Excellence - Transdisciplinary and Global Perspectives. State University of New York Press, Albany, New York, USA, 207-220.

Homoki Andrea (2014): A gyermekvédelmi gondozottak reziliencia vizsgálata a Dél-Alföldi és Észak-Alföldi Régióban. PhD értekezés, Debreceni Egyetem Humán Tudományok Doktori Iskola, 2014. 
Horváth Péter (2013): A fogyatékossággal élők. In: Varga A. (szerk.) Esélyegyenlőség a mai Magyarországon. Pécsi Tudományegyetem, Pécs. 173-194.

Hurtado, S., Alvarez, C. L., Guillermo-Wann, Ch., Cuellar, M. és Arellano, L. (2012): A Model for Diverse Learning Environments The Scholarship on Creating and Assessing Conditions for Student Success. In: Smart, J. C. - Paulsen, M. B. (szerk.) Higher Education: Handbook of Theory and Research, Higher Education: Handbook of Theory and Research 27. Springer Science, Business Media B.V. 41-122. Hurtado, S., Milem, J. F., Clayton-Pedersen, A. R. és Allen, W. A. (1998): Enhancing campus climates for racial/ethnic diversity through educational policy and practice. Review of Higher Education, 21, 3., 279-302.

Imre Anna (2014): Iskolai lemorzsolódást csökkentő oktatáspolitikák. Iskolakultúra, 24, 5, 65-77.

Kalocsainé Sánta Hajnalka és Varga Aranka (2005): Az inklúzió mint társadalmi és oktatási idea. Educatio, 14, 1, 204208.

Keller Judit és Mártonfi György (2006): Oktatási egyenlőtlenségek és speciális igények. In: Halász G. és Lannert J. (szerk.) Jelentés a magyar közoktatásról. Oktatáskutató és Fejlesztő Intézet, Budapest.

Kertesi Gábor és Kézdi Gábor (2009): Általános iskolai szegregáció Magyarországon az ezredforduló után. Közgazdasági Szemle, 56, 11, 959-1000.

Kertesi Gábor és Kézdi Gábor (2014): Iskolai szegregáció, szabad iskolaválasztás és helyi oktatáspolitika 100 magyar városban. (Budapesti Munkagazdaságtani füzetek; BWP - 2014 (6.) MTA KRTK KTI - Budapesti Corvinus Egyetem, Budapest.

Kézdi Gábor és Surányi Éva (2008): Egy sikeres iskolai integrációs program tapasztalatai. Educatio Kht., Budapest.

Kokas Dóra és Lakatos Szilvia (2013a): A nők. In: Varga A. (szerk.) Esélyegyenlőség a mai Magyarországon. Pécsi Tudományegyetem, Pécs, 151-162.

Kokas Dóra és Lakatos Szilvia (2013b): Az idősek. In: Varga A. (szerk.) Esélyegyenlöség a mai Magyarországon. Pécsi Tudományegyetem, Pécs, 163-172. 
Kozma Tamás (1993): Etnocentrizmus. Educatio, 2, 2, 195-210. Kőpatakiné Mészáros Mária (2004): Közben felnő egy elfogadó nemzedék. A sajátos nevelési igényű tanulókat integráltan nevelő-oktató intézmények gyakorlata. Új Pedagógiai Szemle, 54, 2, 34-48.

Kymlicka, W. (2012): Multiculturalism: Success, Failure, and the Future. Migration Policy Institute. Washington DC, USA.

Lannert Judit (2003): Differenciálás és szelekció a magyar iskolákban. Iskolakultúra, 13, 1, 70-73.

Lannert Judit (2004): Hatékonyság, eredményesség, méltányosság. Új Pedagógiai Szemle, 54, 12, 3-15.

Lannert Judit (2014): A korai iskolaelhagyás elleni stratégia és a korai gyermekkori nevelés. Tempus Közalapítvány, Budapest. 55. http://oktataskepzes.tka.hu/document. php?doc_name=Projektek/2013/QALL/07_korai_ neveles_lannert_final.pdf [2015.04. 03.]

Mártonfi György (2014): A korai iskolaelhagyás és néhány kapcsolódó mutató összefüggése. Iskolakultúra, 24, 5, 77-90.

Masten, A. S. és Wright, O’Dougherty, M. (2010): Resilience over the Lifespan: Developmental Perspectives on Resistance, Recovery, and Transformation. In: Reich, J. W., Zautra, A. J. és Hall, J. S. (szerk.) Handbook of adult resilience. Guilford, New York, USA, 213-237.

Masten, A. S. (2001): Ordinary magic: Resilience processes in development. American Psychologist, 56, 3, 227-238.

Meleg Csilla (2003, szerk.): Iskola és Társadalom. Szöveggyűjtemény. Dialóg Campus, Budapest-Pécs.

Messing Vera (2013): Az iskola mint szocializációs terep: kortárs kapcsolatok, tanár-diák viszony nemzetközi összehasonlításban. Esély, 24, 2, 33-52.

Milem, J., Chang, M. és Antonio, A. (2005): Making diversity work: A researched based perspective. Association of American Colleges and Universities, Washington D.C., USA.

Neményi Mária (2013): Oktatási esélyegyenlőtlenségek Európában és Magyarországon. Esély, 24, 2, 3-7.

Németh Szilvia és Papp Z. Attila (2006): „És mi adjuk az integráció vezérfonalát..." In: Németh Sz. (szerk.) Integráció a gyakorlatban. Oktatáskutató Intézet, Budapest, 9-30. 
Orbán Anikó (2013a): Jogszabályi rendelkezések. In: Varga A. (szerk.) Esélyegyenlőség a mai Magyarországon. Pécsi Tudományegyetem, Pécs, 51-98.

Orbán Anikó (2013b): Stratégiák, ágazati politikák. In: Varga

A. (szerk.) Esélyegyenlőség a mai Magyarországon. Pécsi Tudományegyetem, Pécs, 37-50.

Orsós Anna (2012): A beás nyelv megőrzésének lehetőségeiröl. Virágmandula Kft., Pécs.

Papp Gabriella (2012): Az integráció, inklúzió fogalmak tartalmi elemzése gyógypedagógiai megközelítésben nemzetközi és magyar színtéren. Gyógypedagógiai Szemle, 40, 4-5, 295-304.

Percy-Smith, J. (2000, szerk.): Policy Responses to Social Exclusion towards Inclusion? Open University Press, Buckingham, Philadelphia, USA.

Pető Ildikó (2003): Inklúzió a nevelésben. Iskolakultúra, 13, 10, 3-13.

Potts, P. (2002, szerk.): Inclusion in the City: A Study of Inclusive Education in an Urban Setting. Routledge Falmer, London - New York.

Radó Péter (2000): Egyenlőtlenségek és méltányosság a közoktatásban. In: Halász G. és Lannert J. (szerk.) Jelentés a magyar közoktatásról. Oktatáskutató és Fejlesztő Intézet, Budapest, 343-349.

Radó Péter (2007): Méltányosság az oktatásban. Oktatási és Kulturális Minisztérium, Budapest.

Raýman Julianna és Varga Aranka (2015): Reziliencia és inklúzió egy szakkollégiumi közösségben. Romológia, 10.

Réger Zita (1978) Cigány osztály, „vegyes osztály” - a tények tükrében. Valóság, 8.

Réthy Endréné (2002): A speciális szükségletű gyermekek nevelése, oktatása Európában. Magyar Pedagógia, 102, 3, 281-300.

Réthy Endréné (2004): Inkluzív pedagógia. In: Nahalka I. és Torgyik J. (szerk.) Megközelítések. Eötvös Könyvkiadó, Budapest, 231-245.

Réthy Endréné (2013): Befogadás, méltányosság, az inkluzív pedagógia rendszere. Comenius Oktató és Kiadó Kft., Pécs. 
Rutkowski, D., Rutkowski, L. és Engel, L. C. (2014): Inclusiv schooling: fostering citizenship among immigrant student in Europe. Intercultural Education, 25, 4, 269-282.

Szemenyei Mariann és Végh Zoltán Ákos (2013): A gyerekek. In: Varga A. (szerk.) Esélyegyenlőség a mai Magyarországon. Pécsi Tudományegyetem, Pécs, 121-150.

Torgyik Judit (2008, szerk.): Kulturálisan érzékeny iskola. Educatio TársadalmiSzolgáltató Közhasznú Társaság, Budapest. http://kih.gov.hu/documents/10179/1316398/11_ Kulturalisan\%20erzekeny\%20iskola.pdf [2014. 10. 10.]

Varga Aranka (2006): Multikulturalizmus - inkluzív oktatási rendszer. In: Forray R. K. (szerk.) Alapismeretek a romológia asszisztens képzéshez. Pécsi Tudományegyetem BTK Romológia és Nevelésszociológia Tanszék, Pécs, 145-161. http:// mek.niif.hu/04800/04867/04867.pdf [2014. 10. 10.]

Varga Aranka (2012): Az esélyegyenlőség és az inklúzió értelmezési keretei. In: Beck Z. és Cserti Csapó T. (szerk.) Fontos Pont a Hegyhát ifjúság életében! Pécsi Tudományegyetem BTK Romológia és Nevelésszociológia Tanszék Sásd Város Önkormányzata, Pécs, 126-146.

Varga Aranka (2013): Az esélyegyenlőség értelmezési keretei. In: Varga A. (szerk.) Esélyegyenlőség a mai Magyarországon. Pécsi Tudományegyetem, Pécs, 11-15.

Varga Aranka (2014): Az inkluzivitás mint vizsgálati modell. Autonómia és Felelösség, 1, 5-18.

Varga Aranka (2015a): Az inklúzió szemlélete és gyakorlata. PTE, Pécs.

Varga Aranka (2015b): Lemorzsolódás vagy inklúzió. In: Fehérvári A. és Tomasz G. (szerk.) Kudarcok és megoldások - Iskolai hátrányok, lemorzsolódás, problémakezelés. Oktatáskutató és Fejlesztő Intézet, Budapest, 77-92.

Varga Júlia (2015, szerk.): A közoktatás indikátorrendszere 2015. Magyar Tudományos Akadémia, Budapest. 357. http://econ.core.hu/file/download/kozoktatasi/indikatorrendszer.pdf [2015. 04. 23.]

Veressné Gönczi Ibolya (2004): A gyermekvédelem pedagógiája. Kossuth Egyetemi Kiadó, Debrecen.

Vincze Enikő (2012): Társadalmi kirekesztés és interszekcionalitás. Kultúra és közösség, 3, 3-4, 71-86. 
Williams, D., Berger, J., és McClendon, Sh. (2005): Toward a model of inclusive excellence and change in postsecondary institutions. Association of American Colleges and Universities, Washington D.C., USA.

Young, G. és Davis-Russell, E. (2014): The Vicissitudes of Cultural Competence: Dealing With Difficult Classroom Dialogue. In: Asumah, S. N. és Nagel, M. (szerk.) Diversity, Social Justice, and Inclusive Excellence - Transdisciplinary and Global Perspectives. State University of New York Press, Albany, New York, USA, 33-54.

Young, I. M. (2014): Five Faces of Oppression. In: Asumah, S. N. és Nagel, M. (szerk.) Diversity, Social Justice, and Inclusive Excellence - Transdisciplinary and Global Perspectives. State University of New York Press, Albany, New York, USA, 3-32.

Zászkaliczky Péter (2013, szerk.): A társadalmi és iskolai integráció feltételrendszere és korlátai. ELTE Eötvös Kiadó, Budapest. 



\section{HUSZÁR ÁGNES}

\section{A nyelvi szocializáció és az iskola}

A nyelv kiemelten fontos szerepet játszik abban a folyamatban, ahogy a kisgyermek belenő a családba, majd a nagyobb közösségbe. Ahogy Réger Zita írja: „A nyelv szerepének ilyenfajta kiemelését messzemenően indokolja, hogy a szocializáció során a gyermeknek átadott társadalmi és kulturális tudást jelentős mértékben a nyelv közvetíti: a felnőtt környezet a kisgyermek magatartását elsősorban a nyelv segítségével formálja, irányítja”. (Réger, 1990:37)

\section{Mikor kezdődik el a nyelvelsajátítás?}

Erre az egyszerú kérdésre meglepő a válasz: ez a folyamat már születés előtt megkezdődik. A magzat már a terhesség második felében hall, érzékeli környezete zajait, a körülötte lévők beszédét, elsősorban az édesanyjáét. Mikor a baba megszületik, már ismerősnek érzi, sőt kedveli azt a nyelvet, ahogyan hozzá beszélnek. Ezt egy nagyon szellemes kísérlettel igazolták. Négynapos francia csecsemők gyorsabban cumiztak, mikor egy magnóról francia szöveget hallottak, mint amikor oroszt. Még akkor is megmaradt a vonzódásuk az anyanyelvi hangfelvétel iránt, amikor azt annyira torzították, hogy a magán- és mássalhangzók elmosódtak, csak a beszéd dallama maradt meg. Kutatások bizonyítják, hogy már az újszülöttek is képesek hangzásuk alapján megkülönböztetni a környezetükben beszélt két nyelvet. (Kovács, 2014)

A három és négy hónapos kisbaba folyamatosan hangokat ad ki, gőgicsél. A gőgicsélést nem véletlenül nevezik a beszéd előszobájának. A gyerek kipróbálja a környezetében hallott hangokat, csettint, sziszeg és trillázik. Egy egészséges csecse- 
mő öt és hét hónapos korában már kommunikál a környezetével, mosolyog és kifejező gagyogással adja a család tudtára, hogy jól van vagy dühös, esetleg éhes vagy más szükséglete van. Egy éves korában a legtöbb gyerek eljut az első szavak megértéséig és kimondásáig.

Mindebből világos, hogy a gyerekkel veleszületik a beszéd képessége, és ezt a beszélő, segítő környezettel kölcsönhatásban fejleszti nyelvi kompetenciává. De csak egészséges kisbabáknál megy végbe a folyamat gördülékenyen. Mint láttuk, a jó hallás segítségével már a méhen belül "gyưjt ismereteket”, amelyeket aztán felhasznál a gőgicsélés és később a beszéd során. Szakemberek képesek a halláskárosodott csecsemők gőgicsélését megkülönböztetni normálisan halló társaikétól. A siket csecsemők gőgicsélése később kezdődik és egyhangúbb, hiszen nem kapnanak újabb és újabb impulzusokat a környezetétől. A gégefő, száj- és orrüreg nem megfelelő kialakulása is hátráltatja a beszédfejlődést. Ma már minden csecsemőnél rutinszerűen elvégzik a hangképző szervek és a hallás vizsgálatát. A korán felismert hiányosságok mútéti úton jól korrigálhatók.

Az értelmi fogyatékosság hatást gyakorol a nyelvi képességekre, ez megnyilvánul a megkésett beszédfejlődésben, illetve a nyelvi kompetencia töredékes voltában. Ugyanakkor vannak olyan genetikai hátterű szindrómák, pl. a Williams- és a Downszindróma, melyek esetében a beszédkészség másként alakul, mint ahogy azt az általános értelmi elmaradás alapján várnánk. A Williams-szindrómával élő személyek önálló életvezetésre nem képesek, súlyos mentális hiányaik vannak, viszont meglepően jól beszélnek, míg a más feladatokban jobban teljesítő Down-szindrómás embereknek gyengébb a nyelvi teljesítménye. Ennek a ténynek az alapján úgy túnik, hogy a nyelvi képesség nem egyenletesen alakul, a nyelvtan és a szókincs viszonylag önállóan fejlődik. (Részletesebben lásd Lukács és Kas, 2014)

A specifikus nyelvfejlődési zavar (SNYZ, angol rövidítéssel: SLI) normális beszédkörnyezetben élő, átlagos értelmi képességű gyermekeknél lép fel. Nyelvi fejlődésük lassú, gyakran csak 2-3 éves korukban kezdenek el beszélni, a beszédhangokat olyan elmosódottan ejtik ki, hogy csak a környezetük érti meg őket. Szerkezetileg egyszerű, gyakran nyelvtanilag hibás 
mondatokban beszélnek. Logopédiai fejlesztéssel, támogató tanári hozzáállással sokat lehet tenni azért, hogy ezekből a gyermekekből átlagosan kommunikáló felnőtt váljék. (Részletesebben lásd Lukács, Kas és Pléh, 2014)

A gyerek egyéves kora körül már képes arra, hogy egyes szavakat felismerjen környezete beszédében és ezeket maga is kimondja. Ezek általában az ő életével kapcsolatos dolgok pl. ételek: süti, husi, testrészek: szem, orr, játékok: baba, autó, állatok: kutya, cica, családtagok: papa, mama, anyu. Felbukkannak a mindennapi cselekvés szavai: megy, játszik, eszik, valamint melléknevek is: hideg, piszkos, forró. Ebben az életkorban a gyerekek még csak egy-egy szót mondanak, de ezek „mondatokat képviselnek, egy egész gondolatot adnak át, ezért ezt a periódust holofrasztikus szakasznak is nevezik (az Anya számos más lehetőség mellett például állhat az Anya, gyere ide és emelj föl helyett)". (Lukács, 2014:21) Tizennyolc hónapos kortól fogva már két szóból álló, igazi mondatok is megjelennek beszédükben, pl. papa el, kicsi kutya, még süti.

„Tizennyolc hónapos koruk tájékán a nyelv igazi fejlődésnek indul. A gyerekek szókincse átlagosan két óraként gyarapodik egy új szóval, és ez a fejlődési ütem egészen a serdülőkorig megmarad. Elindul a mondattani fejlődés is, a minimális kétszavas mondatokkal." (Pinker, 1999:267) Ezek a mondatok megállapításokat tesznek a környezet egyes tárgyairól, személyeiről, illetve kérnek, kérdeznek valamit.

Az egyes gyerekek jelentősen eltérnek egymástól beszédfejlődésük ütemében, egyesek fél, akár egy évvel is elmaradnak a szokásos ütemtől. Vannak különbségek a lányok és a fiúk között is. A lányok általában „ügyesebbek”, a fiúk „lustábbak” a beszédtanulásban. Arra is vannak adatok, hogy az ikrek egy kicsit elmaradnak az egyedül vagy nagyobb testvérek között felnövő gyerekek beszédfejlettségi szintjétől. Ez azzal magyarázható, hogy a kicsik nemcsak szüleiktől, hanem nagyobb testvéreiktől is kapnak beszédmintákat, ez a tanulási lehetőség az azonos fejlettségi szinten álló ikrek számára nem áll rendelkezésre.

Összességében elmondható, hogy a az ép hallású és értelmi fejlettségű kisgyermek könnyen elsajátítja környezete nyelvét vagy nyelveit. A csecsemő az emberi nyelv képességével 
születik, környezetétől függ, hogy melyik nyelv grammatikai rendszerét és szókincsét sajátítja el, melyiket tekinti majd anyanyelvének. Vietnami árvaházakból származó kisgyerekek élnek szerte a világon, akik német, francia vagy angol anyanyelvükön szólalnak meg, a befogadó kultúrákat tekintik sajátjuknak. Ha egy kisgyermek több nyelvet is aktívan beszélő családba születik bele, akkor többnyelvűként serdül fel. Nem megalapozottak azok a félelmek, amely szerint a több nyelv elsajátítása „megterhelné” a gyermeket. Ellenkezőleg, pozitív hatásai vannak a többnyelvűségnek, ezek közé tartozik a fokozott nyelvi érzékenység és az analógiás gondolkodás fejlettsége.

A beszéd képessége csak egy beszélő környezetben aktiválódik. Ha a gyermek egy átlagos családban vagy akár egy megfelelő nevelőotthonban él, megtanulja a környezetében élő felnőttek és nagyobb gyermekek nyelvét. Érdekes módon még azokban a társadalmakban sem maradnak el lényegesen a kisgyermekek a beszédfejlődésben, ahol kevéssé figyelnek rájuk, pl. az anyák a hátukra kötözött csecsemőkkel dolgoznak a földeken. Természetesen gyorsabban fejlődnek azok a babák, akikkel édesanyjuk állandó élénk kommunikációt folytat, mosolygással, becézéssel, mozdulatokkal bátorítja őket.

A beszéd képességének van egy fontos sajátossága: csak konkrét időhatárok között aktiválódhat. Olyan ez, mint egy ablak, amelyik egy pillanatban kinyílik, aztán visszavonhatatlanul becsukódik. Ezért nevezik időhöz kötött biológiai modulnak. Ilyen például a fogak növése is: először a tejfogak, aztán a tartós fogak növekedése indul be és fejeződik be visszavonhatatlanul, senkinek sem nőnek ki harmadszor a fogai. A beszédtanulás időablaka a terhesség második felében nyílik ki, ekkor szocializálódik a magzat anyanyelve beszédhangjaira, hangmagasságára és intonációs sémáira. Az ablak körülbelül tizenkét éves korban zárul be: az a gyermek, amelyik csak ezt követően kerül beszélő környezetbe, csak pár száz nyelvi jelet tud elsajátítani, sohasem lesz képes olyan gazdag szókincsű és kreatív nyelvhasználatra, mint harmonikusan felnövő társai. Erre bizonyítékokat szolgáltatnak azok a „farkasgyermekek”, akik erdőben éltek, akiket állatok tápláltak, akár Kipling Maugliját. Tudományos feljegyzésekkel is rendelkezünk ilyen esetekről. 1798-ban a franciaországi Aveyron erdejében találtak 
egy tíz-tizenkét éves fiút, aki nem volt képes emberi viselkedésre, természetesen beszélni sem tudott. Jean Itard francia orvos öt évig foglalkozott a Victornak nevezett fiúval, próbálta „megszelídíteni”, beszédre tanítani a kisfiút, aki eleinte nem volt hajlandó házban lakni, ruhát viselni. Az orvos öt év megfeszített munka ellenére is csak nagyon csekély sikereket ért el vele a beszédtanításban. Victor csak pár tucat szót és annak írott képét volt képes egymástól megkülönböztetni. Itard doktor 1806-ban írásban számolt be a pedagógiai fiaskóról. (Itard doktor kísérletéről 1970-ben A vad gyermek címmel egy nagyszerü filmet készített François Truffaut francia filmrendező, a doktor szerepét maga játszotta el.)

\section{A nyelvelsajátítás korai szakaszai}

Egy egészséges kisgyermek természetes módon kíváncsi és kapcsolatba akar lépni a környezetével. Ennek eszköze a nyelv, melynek elsajátítása nagy sebességgel és komplexitással megy végbe. A gyermek közlési vágyával kapcsolatban nevezi Steven Pinker ezt a roppant erős késztetést „nyelvi ösztön”-nek. Természetesen nem biológiai értelemben vett ösztön ez, hanem egy nehezen feltartóztatható vágy, amely súlyos biológiai akadályokat is képes legyőzni. Erre jó példát szolgáltatnak azok a „nyelv nélküli emberek”, akik siketen születtek egy nagyon elmaradott területen, és akiket senki nem tanított meg jelnyelven kommunikálni. Ők ösztönösen kidolgoznak a maguk számára egy jelrendszert, ezen érintkeznek egymással. A beszédtanulás tekintetében a legnehezebb helyzetben az olyan magányosan felnövő gyermekek vannak, mint Itard doktor kis védence.

A hároméves gyerekek már sokat beszélnek és többnyire helyesen alkalmazzák anyanyelvük grammatikai szabályait. Amikor hibáznak, az többnyire túláltalánosítás következménye. A kisgyerekek ekkor már nem egyszerűen szavakat vagy szóalakokat tanulnak, hanem grammatikai szabályokat is, méghozzá úgy, hogy a másoktól hallott mondatokból vonják el őket. Ilyen szabály például az, hogy a tárgyat mint mondatrészt a -t tárgyrag jelöli, pl. mókust, kávét. Azt az alszabályt is hamar megtanulják a gyerekek, hogy az - $a$ és -e végződésű főnevek 
tárgyragos eseteiben -á-t és é-t kell mondani, pl. macskát, medvét. Vannak ennél bonyolultabb esetei is a főnévragozásnak, jó, ha van a családban vagy a tágabb környezetben olyan felnőtt, aki korrigálja a gyermek beszédét. Ha a kisgyermek az alapszabályt túláltalánosítva azt mondaná, hogy: látom a lót, kijavítja: a lovat.

A gyermek elsődleges szocializációja, a nyelvi is a családban történik, de a család nem mindig képes arra, hogy ezt a funkcióját betöltse. Részben azért, mert a felnőtteknek nincs elég idejük erre, részben azért, mert hiányzik hozzá a megfelelő tárgyi és pedagógiai tudásuk. Ha a kisgyermek hozzászokik egy társadalmilag alacsonyan értékelt beszédmódhoz - pl. suksüközik vagy szukszüközik -, akkor ennek az lehet a következménye, hogy butának vagy értelmileg elmaradottnak tartják. Vannak olyan nyelvjárások, ahol a tudhassuk azt a szokásos forma. A magyar köznyelvi norma azonban a tudhatjuk azt. Kijelentő módban kerülendő az elhalasszák forma, ez a felszólító módban helyénvaló halasszák el sorrendben. Kívánatos, hogy a kisgyermekek még az iskolába kerülés előtt hozzászokjanak a normatív nyelvhasználathoz. Ebben sokat tehetnek az óvodapedagógusok nyelvi fejlesztő munkájukkal. Beszédhibák - selypítés, dadogás stb. - esetében pedig a rászoruló gyermekek idejében megkapják a szakszerű logopédusi segítséget.

A gyermekek hat-hét éves korukban eljutnak a kognitív fejlettségnek arra a fokára, amelyben jól tájékozódnak a múltban és a jövőben, képesek különbséget tenni fantáziaviláguk és a realitás között. Ép hallású kisgyermekek esetében a gondolkodás és a nyelv fejlődése elválaszthatatlanul összefügg egymással, a nyelvi kifejezésmód korrektsége, illetve hiányosságai jelzik a gondolkodási folyamatok fejlettségét vagy elmaradottságát. Egy hatéves kisgyermek képes ilyen - tagadással is nehezített - feltételes mondatok megértésére, sőt megszerkesztésére is: „Ha holnap nem esik az eső, elmegyünk az állatkertbe”. A gyermekek iskolaérettségét Magyarországon olyan tesztekkel mérik, amelyekben a térben-időben való tájékozódást összekapcsolják a beszédértési, beszédprodukckiós feladatokkal. A gyerekeknek például olyan felszólításoknak kell eleget tenniük, hogy tegye a piros kört a zöld kocka alá, rá, mellé stb. 
Ha a gyermek számára ezek a feladatok megoldhatatlanul nehéznek bizonyulnak, mód van az iskolába lépés egy éves elhalasztására, illetve célzott fejlesztésre. Erre azért van szükség, mert az iskola alapvetően megváltoztatja a gyermek életmódját, a vele szemben támasztott követelményrendszert. Ennek csak úgy tud megfelelni, ha képes viszonylag hosszabb időn keresztül céltudatosan figyelni egy adott feladatra és elég kitartó ahhoz, hogy a korai kudarcok ellenére újra meg újra nekifogjon.

Az iskoláskorú gyermek sok mindent tud, hallott a környezetében, látott a vizuális eszközökön, de nincsen, kora miatt nem is lehetnek átfogó ismeretei. A gyermekek értelmi fejlettsége amiatt is különbözik egymástól, mert míg egyes gyermekek szellemileg inspiráló környezetben, szeretetteljesen rá figyelő felnőttek között töltötték a gyermekkorukat, más gyerekeknek nem volt ilyen szerencséjük. Az iskola az az intézmény, amely szervezett keretekben közvetíti minden felnövő állampolgár számára az adott korban szükséges tárgyi tudást, a társadalomban való viselkedés alapvető szabályait. Az általános és ingyenes közoktatás célja az, ezért hozták létre, hogy minden egyes gyerek számára megteremtse a társadalomba való sikeres beilleszkedés lehetőségét. Az iskola feladata az is, hogy a hátrányos környezetből jövő, szegényesebb intellektuális „csomaggal” érkező gyerekeket felzárkóztassa szerencsésebb társaikhoz.

\section{Az iskola mint a nyelvi szocializáció próbája és magasabb foka}

Iskolaérettnek csak az a gyermek tekinthető, akinek anyanyelvi szocializációja olyan szinten áll, hogy képes az iskolai munka folyamatába bekapcsolódni, tehát érti az utasításokat és tanácsokat, képes visszakérdezni és társaival együttmúködni. A fejlett kommunikációs készség, az anyanyelv magas szintű ismerete szükséges ahhoz, hogy a gyermek el tudja sajátítani a nyelv írásos modalitását, tehát megtanuljon írni-olvasni. Ez az alapja nemcsak az idegen nyelv elsajátításának, hanem minden szövegalapú tudásnak is. A földrajz, biológia, történelem 
múveltségterületéhez tartozó ismereteket szövegek elolvasásával szerezzük, hogy az irodalmi múvek megismerését ne is említsük. A nyelvi és szövegértési, szövegformálási képesség az iskolai sikeresség szempontjából kulcskompetencia.

Az iskolai oktatás azonban önmagában nem képes arra, hogy minden gyereknek egyenlő esélyt biztosítson. A gyenge érdemjegyek, a bukások, az iskolából való kimaradások mind ennek a kudarcnak a jelei. De kik azok, akik rosszabbul teljesítenek az iskolában? Az emberek értelmi képességei különböznek egymástól, vannak gyengébbek, jók és kiemelkedőek. Ezek a különbségek az egész társadalomban normál eloszlást mutatnak, tehát minden társadalmi csoportba egyenlő esélylyel jutnak jobb és gyengébb képességűek. Abban azonban nagyon is különböznek az egyes társadalmi csoportokhoz tartozó családok, hogyan viszonyulnak gyermekeik képességéhez. A társadalmi hierarchiában alacsonyabb szinten élők könnyebben belenyugszanak abba, hogy gyerekük értelmi feladatokban rosszul teljesít, kicsit „nehézfejü”. A középosztálybeli családok ezzel szemben mindent megtesznek azért, hogy gyerekeik szakszerű segítséget kapjanak a felzárkózáshoz.

A gyermekek iskolai sikertelensége és a szülők társadalmi hovatartozása között összefüggés mutatható ki. Angliában az 1960-as években széles körűen vizsgálták annak az okait, hogy a munkásosztályból származó gyerekek rosszabbul teljesítenek az iskolában, mint középosztályból származó társaik. Gyengébb jegyeket kapnak az iskolában, és kevesen kerülnek be közülük a felsőoktatási intézményekbe. Abban az időben Angliában tizenegy éves korban dőlt el az, hogy az alapfokúból milyen iskolatípusba kerülnek át a gyermekek, olyanba, amely megnyithatja számukra az utat a felsőoktatás és ezzel a társadalmi felemelkedés felé, vagy csak a kétkezi munka irányába. Hogy melyik sorompó nyílik meg előttük, alapvetően a család társadalmi státusától függ. „Ahhoz, hogy egy tizenegy éves munkásgyerek megszerezzen egy gimnáziumi helyet, valamivel magasabb IQ-értékkel kell rendelkeznie, mint egy középosztályi tanulónak." (Lawton, 1974:10) 


\section{A család kommunikációs stílusának hatása a gyermek iskolai sikerességére}

Az 1960-es évek Angliájában sokféle megközelítéssel vizsgálták, milyen szerepet tölt be a család a gyermekek iskolai szocializációjának megalapozásában. Mindenekelőtt a szülők jövedelmére, az otthon fizikai feltételeire, a család nagyságára figyeltek. Nyilvánvaló, hogy a relatív szegénység, az otthoni kulturálódási lehetőségek szúkös volta negatívan befolyásolja a gyermekek tanulási lehetőségeit. Az is világos, hogy a nagycsaládos szülőknek kevesebb idejük jut arra, hogy személyes odafigyeléssel segítsenek külön minden egyes gyereküknek. Még fontosabb tényező a család felnőtt tagjainak beállítódása a tanuláshoz, az ismeretszerzéshez. A gyermek számára tekintélyszemélynek számító szülők az iskolai dolgokra vonatkozó dicséretben vagy figyelmetlenségben megmutatkozó attitűdje nagyon fontos a tanulási motiváció felkeltésében, ami az iskolai sikeresség alapja.

A családok alapvetően különböznek egymástól a nevelési gyakorlatban is követett kognitív (gondolkodási) stílus tekintetében. Josephine Klein pszichológus megkülönböztetett egymástól státusorientált és személyorientált családokat. A státusorientált azt jelenti, hogy a család tagjainak egymáshoz való viselkedését alapvetően az határozza meg, hogy mi az adott személynek a családban betöltött státusa (apa, anya, gyermek). Ez egy zárt hierarchikus rendszer, amelyben a hierarchia csúcsán az apa (a családfő) áll, a fontos döntéseket ő hozza meg. Az anya is alapvetően az apának van alárendelve, feladata a kisgyermekekkel való foglalkozás, a család élelmezése, a lakás, a ház rendben tartása. A gyermekek életének fontos döntéseit, pl. iskolaválasztás a szülők, elsősorban az apa hozza meg.

A személyorientált családban az egyes tagokat - a gyermekeket is - független, döntéshozásra képes személyeknek tekintik. A családra vonatkozó döntéseket nemcsak az egyenrangú szülők hozzák meg, hanem - életkorukhoz mérten - a gyermekeket is bevonják az őket is érintő döntésekbe pl. milyen iskolába menjenek, milyen pályát válasszanak, hol töltse a család a közös vakációt. 
A személyorientált kognitiv stílus elsősorban a középosztály családjaira jellemző, míg a státusorientált stílus főleg a munkásosztály köreiben gyakori. A középosztály tagjai általában rendelkeznek középfokú végzettséggel, sokan közülük egyetemet vagy főiskolát végeztek, a munkásosztály tagjainak végzettsége jellemzően alacsony.

Josephine Klein szerint a státusorientált és a személyorientált család tagjainak kognitív stílusa különbözik egymástól az absztrakciós és a tervezési képesség fejlettségében. Ez azt jelenti, hogy a státusorientált család tagjai kevésbé képesek arra, hogy elvonatkoztassanak a konkrét helyzettől és tudatosan készüljenek a jövőre. Egy pedagógiai szituációban ez azt jelenti, hogy a gyermek nem látja be, hogy a jövendő sikerek - a jó bizonyítvány - érdekében le kell mondania a pillanatnyi örömökről, a fárasztó tanulást kell választania a kellemes játék helyett. Ez szorosan összefügg az önkontroll képességével is. A személyorientált kognitív stílusra - a státusorientálttal szemben - az jellemző, hogy képes a világ rendezett univerzumként való felfogására. Klein a kognitív stílusok különbözőségének okát a nyelvi tudatosságban látja: „Minél kevesebbet beszélnek vagy gondolkodnak szavakban az emberek arról, amit tapasztalnak, annál valószínútlenebb, hogy hasson rájuk valami, ami aktuálisan nem adott tapasztalatuk számára, annál valószínútlenebb tehát, hogy cselekedeteiket homályos, általános vagy elvont, a jövőben rejlő tényezők mérlegelése befolyásolja." (Idézi Lawton, 1974:25)

Klein tehát közvetlen összefüggést állapít meg a nyelvhasználat és az elvont gondolkodás között. Rámutat arra, hogy a felnőttek kognitív stílusa a családi interakciókon keresztül alakítja a gyermekekét.

\section{STÁTUSORIENTÁLT}

- gyenge absztrakciós képesség

- gyenge tervezési képesség

- gyenge önkontroll

- a világ beláthatatlan káoszként való felfogása

\section{SZEMÉLYORIENTÁLT}

- fejlett absztrakciós képesség

- fejlett tervezési képesség

- fejlett önkontroll

- a világ rendezett univerzumként való felfogása 


\section{A nyelvi hátrány bernsteini elmélete}

A vizsgálatok kitértek a gyermek nyelvi kompetenciájának és a család társadalmi helyzetének viszonyára is, és fontos öszszefüggéseket tártak fel közöttük. McCarthy már 1954-ben ezt állapította meg a szakirodalmi adatok alapján: „,a család társadalmi-gazdasági státusa szembetűnően összefügg a gyermek nyelvi fejlődésével". (Idézi Lawton, 1974:25)

Az igazi áttörést azonban a gyermekek nyelvi képességeinek és iskolai előmenetelének összefüggéseiről való gondolkodásban Basil Bernstein angol kutatónak az 1960-as években megjelent írásai hozták. Bernstein gondolkodásának alapvető újdonsága abban nyilvánult meg, hogy nem egyszerüen azt feltételezte, hogy az iskolába kerülő gyermekek jól vagy gyengén birtokolják anyanyelvüket és ez hozzásegíti őket az iskolai tanulás sikerességéhez, illetve korlátozza őket abban. Ő azt gondolta, hogy a tanulatlan szülők alapította - státusorientált - családokban használt nyelvi változat, ezt nevezte ő „korlátozott kód"-nak, egyenesen akadályozza ezeknek a családoknak a gyermekeit a tanulásban. Az iskola tanárai, a taneszközök ugyanis egy másik, bonyolultabb nyelvváltozatot, a bernsteini terminológiával: „kidolgozott kód”-ot használnak és annak használatát várják el a tanulóktól.

Bernstein a társadalmon belüli nagyobb csoportok kultúrájához, az úgynevezett szubkultúrához köti ezt a fajta nyelvhasználatot: „Korlátozott kód ott alakul ki, ahol a társadalmi viszony formája az egymással való azonosuláson, közös elvárásokon, azonos előfeltevések sorozatán nyugszik, ahol a kultúra vagy szubkultúra az én fölé emeli a mit." (Bernstein, 1975:399)

Az iskola a tanulóknak az úgynevezett magaskultúrát közvetíti, ennek része egy bonyolult viszonyokat tükrözni képes nyelvi változat: „Mindenütt, ahol a kultúra vagy szubkultúra az ént hangsúlyozza a mivel szemben, ahol a többi személy szándékát nem tekintik magától értetődőnek, kialakul egy kidolgozott kód. Amennyiben ugyanis a többi személy szándékát nem lehet magától értetődőnek tekinteni, a beszélők kénytelenek jelentéseiket kidolgozni, explicitté és sajátossá tenni. A beszélőre korlátozott, diszkrét, tagolt jelentéseket át kell alakítani, hogy érthetőek legyenek a hallgató számára, és ez arra kény- 
szeríti a beszélőt, hogy válogasson a szintaktikai és szókincsbeli alternatívák között." (Bernstein, 1975:400)

A két nyelvi változat főbb jellemzői:

KORLÁTOZOTT KÓD

- rövid, grammatikailag egyszerü mondatok

- aktív igék túlsúlya

- rövid felszólítások és kérdések

- korlátozott melléknévhasználat

- kevés személytelen névmás (senki,

bárki) használata

- konszenzusra irányuló kérdések (ugye?)

- korlátozott szimbolizmus

- az absztrakt gondolkodást elősegitő

eszközök nem kielégítő birtoklása
KIDOLGOZOTT KÓD

- bonyolult felépítésü (összetett)
mondatok
- aktív-passzív igék megfelelő aránya
- grammatikai eszközök adekvát
használata
- változatos melléknévhasználat
- személytelen névmások gyakori,
adekvát használata
- egyéni minősítés, következtetés
(szerintem)
- kifejező szimbolizmus
- az absztrakt gondolkodást elősegítő
eszközök kielégitő birtoklása

Az összehasonlítás értelmezésekor figyelembe kell venni, hogy Bernstein angol nyelvi változatokról beszél, ezeknek jellemzésekor az angol nyelvhasználatból indul ki. Amikor a korlátozott kód egyik jellemzőjeként említi a túlnyomóan aktív igehasználatot, a kidolgozott kódnál pedig az aktív-passzív igék megfelelő arányát, az angol nyelvnek arra a sajátosságára utal, hogy szinte minden cselekvés kifejezhető aktív, illetve passzív igével. Angolul mondható az, hogy John rúgja a labdát, de az is, hogy A labda rugatik John által. A kidolgozott kódot beszélő ember nagyjából fele-fele arányban használja az aktív és a passzív igéket, az angol anyanyelvűeknek ez tűnik „természetesnek". A korlátozott kódon kommunikálók eltérnek ettől, ők szinte kizárólag aktív igéket alkalmaznak beszédükben.

A kidolgozott kódot beszélő ember birtokában van anyanyelve teljes grammatikai struktúrájának, a korlátozott kódot használó viszont csak annak leggyakoribb eszközeit képes használni. A korlátozott melléknévhasználat nemcsak arra utal, hogy az illető anyanyelve szókincsének csak egy kis részét használja, hanem arra is, hogy nem képes a világ dolgait, személyeit, történéseit adekvát módon értelmezni, leírni. A korlátozott kódot használók esetében a beszédükben előforduló csekély számú személytelen névmás (minden, senki, bár- 
ki) azt mutatja, hogy ők csak kevéssé tudnak felemelkedni az elvont gondolkodás szintjére. A filozófiai vagy jogi diskurzus megállapításai a mindenkori kontextust figyelmen kívül hagyva érvényesek pl. minden ember halandó, senki sem vonhatja ki magát a törvény hatálya alól. A kidolgozott kód adekvát használata feltételezi a fejlett absztrakt gondolkodást.

A korlátozott kódot beszélő közösség tagjaira jellemző, hogy a mi-tudat fontosabb az egyénnél. Ez mutatkozik meg a konszenzusra irányuló kérdések, például ugye, hát nem? gyakori használatában. Az egyén újra meg újra meg akar győződni társai egyetértéséről. A kidolgozott kódot beszélő ember ennek éppen az ellentéte: neki az a fontos, hogy saját egyéni véleményét képviselje. Ennek nyelvi jelei a szerintem, a véleményem szerint. A korlátozott kódot beszélőkre jellemző, hogy sokszor kész mondatokban, klisékben fogalmaznak, beszédükben ritkán fordul elő szimbolizmus, képszerű elemek. Ezek használata a kidolgozott kódra jellemző. Az absztrakt gondolkodást elősegítő nyelvi eszközök közül említettem már a személytelen névmásokat, de ide tartoznak a kötőszók is. Csak aki megfelelő módon alkalmazza az okra, célra utaló, egyidejűséget, elő- vagy utóidejűséget kifejező kötőszavakat, tud megbízhatóan eligazodni a tér-idő koordináták világában, az okok és következmények között. Az és, meg, mert, aztán kötőszavak túlságosan gyakori használata arra utal, hogy a beszélő nincs tisztában ezekkel a viszonyokkal. Világosan kell látnunk a gondolkodás és a nyelvhasználat elszakíthatatlan összefüggéshálózatát: tudatos fejlesztésük is csak ebben a kettős hatásrendszerben képzelhető el.

Bernstein és tanítványai, mindenekelőtt Lawton empirikus vizsgálatokkal bizonyították azt, hogy az alsóbb társadalmi osztályokból származó gyerekek az iskola által megkívánt feladattípusok megoldásában gyengébben teljesítenek. A kísérletekben részt vevő gyermekek életkoruk és az IQ-teszt nem verbális feladataiban elért eredményeik alapján összehasonlíthatók voltak, az egyetlen különbség a családi hátterükben rejlett.

A munkáscsaládokból és a középosztálybeli családokból származó gyerekeket külön csoportba osztották és nyelvi feladatokat oldattak meg velük. Ezeket a feladattípusokat már a 20. század elejétól fogva alkalmazták a gyermekek anyanyelvi 
kompetenciájának mérésére. Egyes feladatok során megadott szavakból, pl. vadász, nyúl, puska, mező kell mondatokat alkotni vagy megkezdett mondatokat befejezni, egy-két-három szóval továbbfüzni. Ezeket a feladatokat úgy alakították, hogy kiderüljön belőlük, mennyire képes a gyermek a bonyolult szintaktikai struktúrák, például a nyelvtani alárendelés kezelésére. Ha azt a feladatot kapja a gyermek, hogy fejezze be a következő mondatot a vonatkozó névmások felhasználásával: A fiú meglátta a lányt, akit/amikor, ahol... fény derül nyelvi kompetenciájának szintjére.

Voltak olyan feladatok, amikor a gyerekeknek történeteket kellett mesélniük. A szöveget rögzítették és aprólékosan elemezték. Mérték a szókincs nagyságát, a mondatok átlagos hosszúságát, az összetett és bonyolult - többszörös alárendelést tartalmazó - mondatok korrekt alkalmazásának gyakoriságát. Elemezték a gyermekek szövegeit a bennük előforduló szófajok szempontjából is, és kimutatták, mennyire változatos a szóhasználatuk. A névmások esetében külön kezelték a kontextusfüggó és kontextustól független használatot.

A gyerekekkel fogalmazást írattak Az otthon, Életem tíz év múlva címmel. Ezek alkalmat adnak sokrétű grammatikai és tartalmi elemzésre, de megmutatják azt is, mennyire képes a gyermek hosszú távú tervezésre, mennyire látja magát nemcsak egyénként, hanem a társadalom felelős tagjaként is. A munkásosztályból és a középosztályból származó, egyformán „okos” gyerekek meglehetősen eltérő eredményeket értek el. A munkásgyerekek jóval rövidebb fogalmazásokat írtak, mint középosztályi társaik, a leglényegesebb különbség a két csoport írásai között az absztrakciós szint elérésében ragadható meg. Lawton idézi egy munkásosztálybeli fiú dolgozatát, amelyben kísérletet tesz az absztrakt fogalmazásra, majd feladja, és írását összefüggéstelen mondathalmazzal fejezi be. (Lawton, 1974:129)

A beszélgetések elemzései hasonló eredményekkel jártak. A halálbüntetésről szóló vita lehetővé tette a téma elvont, szinte jogi precizitású kezelését, de azt is, hogy valaki leragadjon egy nyelvi klisénél, pl. „szemet szemért, fogat fogért”, vagy egy konkrét eset latolgatásán, pl. „volt a tévében egy srác”. A munkásosztálybeli fiúk általában nem jutottak el a probléma 
absztrakt szintre emeléséig, vagy ha igen, nagyon töredékes eredménnyel.

\section{A szociális hátrány nyelvi hátrányt okoz, majd ennek következtében újratermelődik}

Basil Bernstein elméletének forradalmi újdonsága abban áll, hogy a társadalmi struktúra átörökítési mechanizmusaként ismerte fel a nyelvi szocializációt. Aki rabja marad a korlátozott kódszerű beszédmódnak, az nemcsak az iskolában nem lesz sikeres, hanem az életben sem. Annak a fizikai munkát végző csoportnak, annak az osztálynak a tagja lesz maga is, amelyből származik. A gazdagsághoz, a független, érdekes élethez vezető társadalmi mobilitás ajtói zárva maradnak a számára.

Bernstein és tanítványai empirikus vizsgálatokkal bizonyították be, hogy a társadalom alsóbb rétegeiben szokásos nyelvhasználat leszúkíti az iskolai követelmények rendszerén keresztül az egyén lehetőségeit. Elméletének lényege az, hogy a nyelvi relativitás elméletét alkalmazza egy nyelven belül megfigyelhető két változatra (az úgynevezett korlátozott és kidolgozott kódra). A nyelvi relativitás elmélete - Sapir-Whorfhipotézisnek is nevezik - szerint az elsőnek elsajátított nyelv alapvetően meghatározza, bizonyos értelemben korlátozza azt, ahogyan a nyelven kívüli világot látjuk. Sapir így fogalmazta ezt meg: „A reális világ nagy mértékben tudattalanul a csoport nyelvi szokásaira épül. Azok a világok, amelyekben a különböző társadalmak élnek, különböző világok, nem pedig ugyanaz a világ különböző megnevezésekkel ellátva. Nagyrészt azért látunk, hallunk, tapasztalunk úgy, ahogy tesszük, mert közösségünk nyelvi szokásai eleve hajlamossá tesznek minket bizonyos értelmezések kiválasztására." (Idézi Lawton, 1974:81) Bernstein felfogása szerint azt tapasztaljuk a világból, amit kódunk, nyelvváltozatunk közvetíteni képes belőle.

A korlátozott kód használata kiválóan megfelel arra, hogy egy alapvetően mi-tudatú közösség elfogadott tagjaként azonosítsanak bennünket. A beszéd egy ilyen közösségen belül az egymással való azonosulás kinyilvánítására szolgál, a közös elvárásokat, azonos előfeltevéseket mondja fel. Ennek jelei a 
Bernstein által szociocentrikus szekvenciáknak nevezett fordulatok, pl. tudod?, ugye? A közösségi tudás, amit ez a beszédmód állandóan ismételve örökít, mindennapi, doxa jellegű tudás, jellemző rá a túláltalánosítás, az egyből az egyre való következtetés, az időbeli egymásutániság ok-okozati viszonyként való téves azonosítása. Jellemző rá a semmitmondó klisék ismételgetése: a férfiak (a nők) már csak ilyenek, (nem) így müködik a világ, mindig így volt, mindig így lesz stb.

A kidolgozott kód ezzel szemben lehetőséget ad arra, hogy saját véleménnyel rendelkező egyénként mutassuk meg magunkat. Erre alkalmasak a Bernstein által egocentrikus szekvenciáknak nevezett nyelvi formák, pl. szerintem, nézetem, véleményem szerint. A kód tartalmaz az absztrakt gondolkodást elősegítő eszközöket, névmásokat, kötőszavakat. Lehetővé teszi a metaforikus, szimbolikus megfogalmazásokat. Pontosan ki lehet ezen a kódon fejezni az okok, célok, következtetések hálózatát, a bonyolult időviszonyokat. Ez a nyelvi változat alkalmas az episztemé, a tudományos tudás kimunkálására.

Bernstein elmélete nagy visszhangot váltott ki világszerte, és korántsem csak szakmai berkekben. Ez nem véletlen, hiszen nem egyszerüen pedagógiai és meg kevésbé nyelvészeti kérdésről van szó. Bernstein tételének ugyanis konkrét politikai összefüggései vannak. Azok a kétkezi dolgozók családjából származó tehetséges gyermekek, akik kommunikációs-nyelvi hátrányuk következtében az iskolában sikertelenek, a társadalmi mobilitásból is ki vannak zárva, hiszen számukra a középosztályba való felemelkedésre elsősorban a felsőfokú diploma adna lehetőséget. A társadalmi mobilitásnak persze vannak más útjai is. A vállalkozói világban nemcsak diplomával lehet érvényesülni, hanem ügyes befektetői szemlélettel, kreativitással is. De a gazdasági életben való érvényesülésnek is feltétele, hogy az ember jól, hatásosan tudjon beszélni, meggyőzzön másokat. A politikai, az érdekérvényesítő tevékenység feltétele szintén a meggyőző kommunikációs képességeken alapuló fellépés. 


\section{A bernsteini elmélet recepciója Németországban, az Egyesült Államokban és Magyarországon}

Az elmélet elsősorban politikai relevanciája miatt váltott ki élénk vitákat számos országban, elsősorban azokban, amelyekben az 1968-as diáklázadások komoly nyomokat hagytak az egyetemi szférában és a közéletben. Olyan fiatal kutatók dolgoztak lelkesen ezeken a projekteken, akik mélyen átérezték a társadalom alsóbb osztályaiból származó gyermekek esélytelenségének igazságtalan voltát.

Az Amerikai Egyesült Államokban a korlátozott kódot a helyi feketék által beszélt változattal azonosították, amelyet „hibás” nyelvhasználatként bélyegeztek meg. Az amerikai szociolingvisztika tekintélyes alakja, William Labov egy nagy jelentőségű tanulmányt írt a feketék használta „nemsztenderd-angol” logikájáról. Ennek a változatnak a normába való beemelését szolgálta az 1979-es Ann Arborban hozott bírói ítélet, amely kimondta - többek között Labov szakértői véleményére alapozva -, hogy az iskolában nem érheti hátrányos megkülönböztetés a saját dialektusukat használó színesbőrű gyerekeket.

Németországban többen - például Siegfried Jäger és UIrich Oevermann - megismételték az angliai kísérleteket. Ennek során bevonták a vizsgálatba az óvodás korosztályt is, és az eredetinél sokkal kifinomultabb módszertannal dolgoztak. A nyelvészek reagáltak a sajátos németországi nyelvi helyzetre is, amelyet a dialektusok óriási különbözősége jellemez. Az egyes helyi változatok, pl. a bajor, a szász a regionális szépirodalommal együtt komoly azonosulási lehetőséget adnak a helyi lakosoknak. A német köznyelv birtoklása viszont feltétele egy országos szintű karriernek. Ammon és társai olyan kontrasztív tananyagokat dolgoztak ki, amelyek szemléletesen mutatták be a tanulóknak a helyi dialektus ( $p l$. az alemann) és a német köznyelv szerkezeti, szókincsbeli különbségeit. Ezek a könyvek egyszerre szolgálják a helyi értékek őrzését és a nemzeti szintű kommunikációra való felkészítést.

Magyarországon is folytak vizsgálatok a társadalmi osztályhoz kötött nyelvhasználat témakörében. Ezek azt bizonyították, hogy a lakóhelyi környezet lényegesebb hatást gyakorol a 
gyermekek nyelvhasználatára, mint a családnak a társadalomban elfoglalt helye. (Pap és Pléh, 1972) A bernsteini elmélet inspirációjának hatására folytatta le Réger Zita a cigány gyermekek iskolai beilleszkedését elemző vizsgálatait. Megállapításai - például a szegregált oktatásra vonatkozók - mind a mai napig érvényesek. (Réger, 1985)

\section{A bernsteini elmélet kritikája}

Bernstein elméletét számos szerző illette megalapozott kritikával. A bírálatok jó része az általa alkalmazott osztályfogalom körvonalazatlanságára irányult. Felvetették azt is, hogy nem tesz különbséget az alkalmi munkákból tengődő, tanulatlan, sokszor a bűnöző életmód peremére kerülő lumpenproletariátus és a komoly képzettséggel rendelkező, értékteremtő munkát végző szakmunkásréteg között. Jogos kritikaként fogalmazódott meg az is, hogy a mezőgazdasági dolgozók az ipari munkássághoz hasonlóan a társadalmi hierarchia alján állnak, az elmélet azonban nem vesz tudomást róluk.

A munkásosztály kategóriája a marxi elméletből származik, alapja a termelőeszközökhöz való viszony. A munkás nem rendelkezik ezekkel az eszközökkel, ezért puszta munkaerejét bocsátja áruba, a gyárat múködtető kapitalista viszont tulajdonosa a termelőeszközöknek (épületek, gépek, nyersanyagok). A munkás erejével múködteti ezeket, a piacon áruként értékesíthető termékeket hoz létre általa.

A bernsteini elmélet kidolgozásának idején, a huszadik század hatvanas éveiben Angliában nagyszámú és szervezett munkásság élt. Az ipari munkások érdekvédelmét ellátó szakszervezetek rendelték meg azokat a kutatásokat, amelyek arra a kérdésre keresték a választ, miért kerül olyan kevés munkásgyerek a felsőoktatásba

A társadalmi struktúrák az elmúlt ötven-hatvan évben lényegesen megváltoztak Angliában és szerte a világon. Ennek a változásnak az egyik leglényegesebb következménye a nagy létszámú munkásság eltűnése volt. Ez Angliában a nyolcvanas években kezdődött meg, Magyarországon a rendszerváltozás után ment végbe nagy gyorsasággal. A termelőszövetkezetek 
felbomlásával a mezőgazdasági dolgozók is szociológiailag nehezen megfogható réteggé váltak.

A németországi kutatások vezetői pl. Jäger és Oevermann nem is használták a munkásosztály kategóriát. Helyette egy hierarchikus struktúrába (felső réteg, középréteg, alsó réteg) való besorolást alkalmaztak egy bonyolult számítás alapján. A hovatartozást a család jövedelmi viszonyai, a szülők iskolai végzettsége és a társadalmi termelésben elfoglalt helye alapján számították ki.

Többen, pl. a német Ulrich Ammon és a magyar Pap Mária is bírálták a bernsteini koncepciónak azt az elemét, amely szerint a korlátozott kód silányabb nyelvi változat, mint a kidolgozott kód. Bernstein ezt soha nem is írta le, de a követői ezt sugallták, amikor „deficithipotézis”-nek nevezték az elméletet. Ők úgy érveltek, hogy mindkét nyelvi változat tökéletesen adekvát, csak más-más szituációban. Ammon és mások az elméletet éppen ezért nevezik „differenciahipotézis”-nek.

\section{Összegzés}

Bernstein és követői olyan összefüggéseket tártak fel a szülők társadalmi helyzete és az iskolai sikeresség, ezen keresztül pedig a mobilitás között, amelyet az elmúlt évtizedek tapasztalatai csak megerősítettek. A bernsteini elmélet, bár számos elemét érte jogos kritika, még mindig fontos magyarázó erővel bír. A társadalomban élő nyelvi változatok közötti alapvető különbség szemléletbeli, nem pedig egyszerűen minőségi vagy mennyiségi.

A pedagógia célja, hogy kiegyenlítse a családból hozott kulturális különbségeket és minden egyes gyereknek lehetőséget biztosítson a társadalmi mobilitásra. Ennek a célnak az érdekében fejleszteni kell a gyermekek nyelvhasználatát, ez pedig nem könnyű feladat. Egyszerű szókincsfejlesztéssel vagy kommunikációs tréningekkel nem megyünk sokra. A hatékony fejlesztésnek már jóval az iskolába lépés előtt meg kell kezdődnie, ennek az intézményes kereteit a bölcsődei és óvodai nevelés adja meg. Az óvodapedagógusoknak kell pótolni a szülő által elmulasztott célzott fejlesztést, például ilyen beszélgetést 
kell folytatni a gyerekekkel: „a felnőttek a kisgyerek környezetében mintegy 'megállítják' az ingerek áradását, rögzítik a témát a múló idő s az ingatag figyelem viszonyai között, kijelölik egy a gyerek és a szülő között folyó, kölcsönös együttműködésen alapuló beszélgetés céljaira. Mindennek során a gyerek megtanul az adott dologra figyelni, elsajátítja a kapcsolatot a szó és az általa jelölt dolog között, társalgási eljárásokat gyakorol be, majd idővel maga is elbeszélő szövegeket alkot, amelyekben az elsajátított elemek eredeti előfordulásuktól eltérő összefüggésekben jelennek meg." (Réger, 1990: 135)

$\mathrm{Az}$ iskola erre az alapra építve tud tovább haladni, egyéni fejlesztéssel segítve a gyerekeket a szövegértésben - ami minden verbális tudás alapja - és a szövegalkotásban. A fiatal emberből csak ezeknek a kompetenciáknak a birtokában lesz saját és mások érdekeit hatékonyan képviselő felnőtt és a társadalom számára értékteremtő alkotó ember.

\section{Irodalomjegyzék}

Bernstein, B. (1975): Nyelvi szocializáció és oktathatóság. In: Pap M. és Szépe Gy. (szerk.) Társadalom és nyelv. Szociolingvisztikai írások. Gondolat Kiadó, Budapest, 393-431.

Kovács Ágnes Melinda (2014): Korai kétnyelvűség és szociokognitív fejlődés. In: Pléh Cs. és Lukács Á. (szerk.) Pszicholingvisztika 2. Akadémiai Kiadó, Budapest, 551-574.

Lawton, D. (1974): Társadalmi osztály, nyelv és oktatás. Gondolat Kiadó, Budapest.

Lukács Ágnes (2014): Szótanulás. In: Pléh Cs. és Lukács Á. (szerk.) Pszicholingvisztika 2. Akadémiai Kiadó, Budapest, 521-550.

Lukács Ágnes és Kas Bence (2014): Nyelvelsajátítás és értelmi fogyatékosság. In: Pléh Cs. és Lukács Á. (szerk.) Pszicholingvisztika 2. Akadémiai Kiadó, Budapest, 1383-1403.

Lukács Ágnes, Kas Bence és Pléh Csaba (2014): A specifikus nyelvfejlődési zavar. In: Pléh Cs. és Lukács Á. (szerk.) Pszicholingvisztika 2. Akadémiai Kiadó, Budapest, 1265-1323.

Pap Mária és Pléh Csaba (1972): Nyelvhasználat és társadalmi helyzet. Szociológia, 1, 211-234. 
Pinker, S. (1999): A nyelvi ösztön. Hogyan hozza létre az elme a nyelvet? Typotex, Budapest.

Réger Zita (1985): Beszámoló „A halmozottan hátrányos helyzet és a nyelvi fejlettség" címü folyamatban levő kutatási projektum néhány eredményéről. Múhelymunkák a nyelvészet és társtudományai köréből. MTA, Nyelvtudományi Intézet. I., 87-118.

Réger Zita (1990): Utak a nyelvhez. Nyelvi szocializáció - nyelvi hátrány. Akadémiai Kiadó, Budapest. 



\section{LANNERT JUDIT}

\section{Hatékonyság, eredményesség és méltányosság a közoktatásban}

A hatékonyság, eredményesség és méltányosság olyan, a közoktatás területén gyakran használt értékfogalmak, amelyek jelentése és egymáshoz való viszonya a szakma számára sem egyértelmű. A hatékonyságot gyakran a költséghatékonyság értelmében használják, és nem ritkán az olcsóság szinonimájának tekintik. Az egyenlőség vagy méltányosság fogalmát pedig gyakran az eredményesség ellentettjeként értelmezik, feltételezve, hogy az a méltányosság, amely esélyegyenlőséget teremt az oktatási szolgáltatásokhoz való hozzáférés terén, nem kedvez az elitoktatásnak, márpedig - e nézetet vallók szerint - elitoktatás nélkül nincs eredményesség, nincs minőségi oktatás. A nemzetközi kutatások adatai ezzel szemben azt mutatják, hogy ez a három értékdimenzió egymással szorosan összefügg, és valójában akkor beszélhetünk minőségről az oktatás terén, ha az oktatás egyszerre teljesíti a hatékonyság, az eredményesség és a méltányosság feltételeit (kritériumait).

A három értékdimenzió ugyanakkor nem mindig egyformán hangsúlyos. Magyarországon a kilencvenes évek közepén - amikor a dinamikusabb növekedési pályára való állás nagymértékű megszorításokat követelt a közszférában - különösen erőteljesen merült fel az oktatás hatékonyságának kérdése. A kilencvenes évek második felében a szegregáció látványos növekedésével a méltányosság kérdése került a középpontba, míg a PISA nemzetközi vizsgálat adatai ${ }^{1}$ az oktatás eredményességére irányította a reflektor fényét. A 2007-es válság óta pedig mintha újra a költséghatékonyság lenne az első számú prioritás. 


\section{Eredményesség és hatékonyság (effectivity and efficiency)}

A hatékonyságot közgazdasági értelemben kétféleképpen is megközelíthetjük: adott erőforrásból kell minél többet kihozni vagy ugyanazt az eredményt minél kevesebb befektetéssel elérni. Ugyanakkor ez a kétféle értelmezés mégsem jelenti ugyanazt. Az első értelmezés szerint a cél, hogy minél többet hozzunk ki a meglévő erőforrásainkból, a másik szerint viszont az, hogy valamit minél olcsóbban állítsunk elő. A közszféra és a közoktatás számára is a cél az, hogy minél többet hozzon ki a meglévő erőforrásokból, nem pedig, hogy egy adott szintet - ráadásul, ha ez a szint igen alacsony - minél olcsóbban biztosítson. Közgazdasági értelemben sincs értelme hatékonyságról beszélni akkor, ha selejtet gyártunk. Az, hogy valaki 10 darab vagy 1 darab selejtes cipőt gyárt egy óra alatt, érdektelen, jó cipőt kell gyártani. (Ugyanakkor az már korántsem érdektelen, hogy a jó cipőt mennyiért állítjuk elő.) (Lannert, 2004)

A közoktatás közpénzekből fenntartott közszolgáltatás, ahol törvényileg is rögzítve van a szolgáltatás minimuma. Ilyen a tankötelezettség betartása és a tantervi szabályozás által lefektetett minimumok garantálása. Vajon teljesíti-e a magyar közoktatás a törvények által tőle elvárt minimumokat? Az írniolvasni tudás szintjéről a PISA felmérés ad nemzetközi viszonylatban is összemérhető képet a magyar oktatásról (lásd 1. ábra). A legutóbbi felmérésen a 15 éves magyar tanulók húsz százaléka teljesített nagyon gyengén, az egyes vagy az egyes szint alatt. Ez utóbbiak gyakorlatilag funkcionális analfabétáknak tekinthetők.

Amennyiben időben nézzük a magyar közoktatás teljesítményét, úgy azt látjuk, hogy több kompetenciaterületen romlás következett be, a legszignifikánsabb mértékben a matematika területén, de jelentősen elmaradunk az OECD-átlagtól a problémamegoldás vagy a digitális szövegértés terén is (ez utóbbi esetében Európában az utolsó helyen álltak 2012-ben a magyar tanulók). A környező országokkal összehasonlítva azt láthatjuk, hogy bár 2000-ben még a lengyel és német tanulók teljesítménye hasonló volt a magyarokéhoz képest, 2012-re már jócskán elmaradtak a teljesítményeink a régió több országától (lásd 2. ábra). 
1. ábra. A diákok képességszint szerinti megoszlása a szövegértés terén, PISA 2012 (forrás: Balázsi és mtsai, 2013)

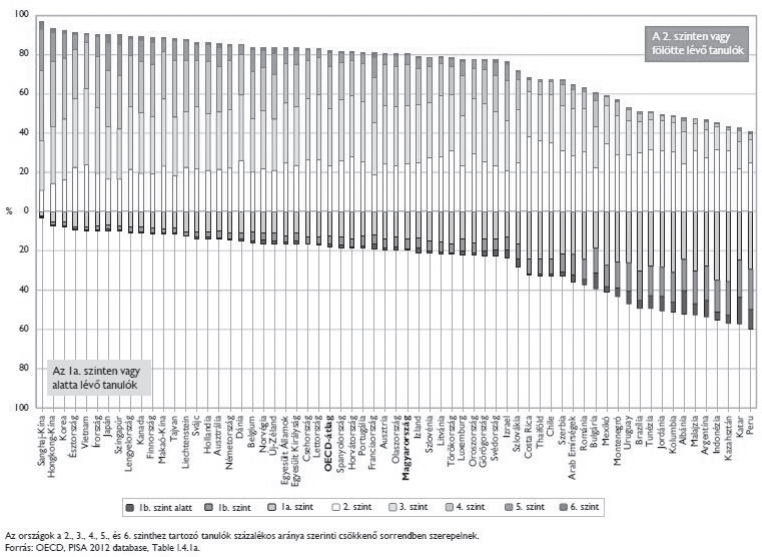

2. ábra. A lengyel, magyar és német tanulók teljesítménye a szövegértés (SZ) és a matematika (M) terén, PISA, 2000, 2003, 2006, 2009 és 2012 (forrás: PISA, 2012)

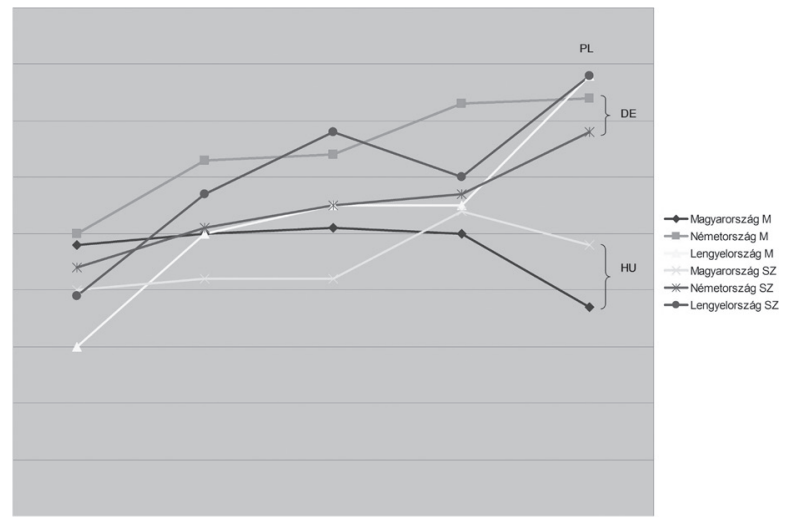


Felmerül a kérdés: vajon nem azért alacsonyabb a teljesítményünk, mert kevés erőforrást fordítunk az oktatásra? Ezt a kérdést a látszattal ellentétben egyáltalán nem könnyű megválaszolni. A PISA-eredmények tanúsága szerint a közhiedelemmel ellentétben az oktatásra fordított összegek nem lineárisan térülnek meg, vagyis nem igaz, hogy minél többet fordítunk az oktatásra, annál jobb lesz a színvonala. A nemzetközi adatok azt mutatják, hogy egy bizonyos fajlagos ráfordítás (egy tanulóra jutó paritásos összeg) alatt a befektetések növelésével még ugyan lineárisan növelhető az eredményesség, de egy bizonyos összeghatár fölött már nem (lásd 3. ábra). Úgy tűnik, hogy az átváltási pont (trade-off) az 50000 USD per tanuló összegnél található. Sajnálatos módon Magyarország korábban a trade-off fölött volt, 2012-re viszont ez alá csúszott, tehát elmondható, hogy a magyar közoktatásra fordított öszszegek alacsonynak tekinthetők, növelésük minden bizonnyal javítaná az eredményességet.

3. ábra. Az egy tanulóra jutó kumulált ráfordítás és a matematikaeredmények (forrás: Balázsi és mtársai, 2013)

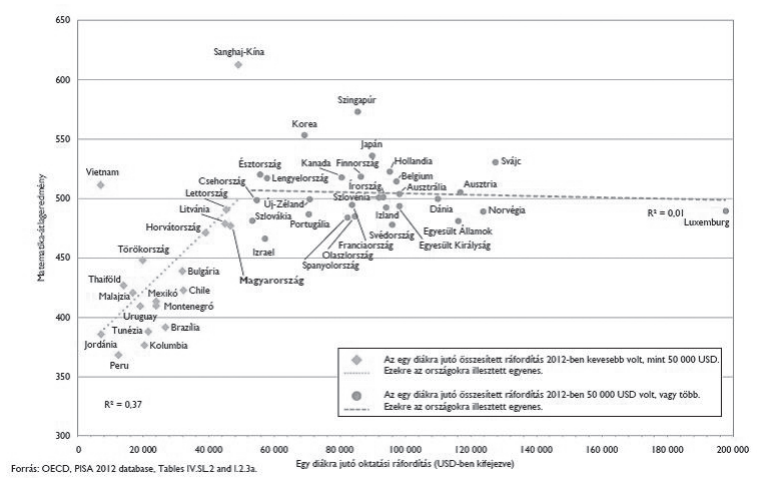

A 3. ábra jól szemlélteti, hogy 50000 USD per tanuló összeg feletti költések esetén már nincs egyértelmú kapcsolat a költés nagysága és az oktatás eredményessége között. Csehországtól kezdve Luxemburgig az országok egyre többet költenek az 
oktatásra, mégis ezekben az országokban a tanulók 2012-es matematikaeredménye az átlagos 500 pont körül mozog. Láthatjuk a 3. ábrán azt is, hogy az ázsiai országok többsége az illeszkedő egyenes fölött helyezkedik el, vagyis adott ráfordításból sokkal több eredményt érnek el, mint a többi ország. Jól láthatóan nem pusztán az oktatásra fordított erőforrások mennyisége, de azok felhasználásának módja is fontos. Alapvetően két ráfordítási tényező befolyásolja az eredményességet, a pedagógusok bére és a pedagógusok száma. Az oktatási költségvetések 80 százalékát világszerte a pedagógusbérek adják. A pedagógusokra fordított költségeket pedig egyaránt befolyásolja a bérek színvonala, illetve az a tény, hogy menynyi pedagógust alkalmaz a rendszer. Ez utóbbit leginkább az osztályok, csoportok nagyságával tudják szabályozni. Ezeket a ráfordítás jellegű tényezőket nemzetközi összehasonlításban szintén az OECD kínálja fel, az 'Education at a Glance' köteteiben. ${ }^{2} \mathrm{Ha}$ összevetjük $A$ különböző ráfordításokat az eredményességgel, azt tapasztaljuk, hogy valóban nem látszik egyértelmü kapcsolat (lásd 1. táblázat).

Egy ország hatékonyságát ugyanis egyes szakértők szerint több tényező, a pedagógusbérek, az osztálynagyság és a teljesítmény együttes kombinációja adja ki. ${ }^{3}$ Ennek függvényében egyaránt találhatunk olyan országot, amelyek sok ráfordítással keveset érnek el, mint fordítva, kevesebb erőforrással relatíve jól teljesítenek. A PISA-eredményeket a pedagógusok bérével és az egy pedagógusra jutó tanulóaránnyal összevetve szakértők kidolgozták az ún. oktatáshatékonysági indexet (lásd 2. táblázat). 
1. táblázat. A matematikateljesítmény és a különböző ráfordítások az OECD néhány országában, 2012

\begin{tabular}{|c|c|c|c|c|c|}
\hline & \multirow{2}{*}{$\begin{array}{l}\text { Az évi } \\
\text { tanítási } \\
\text { idő az } \\
\text { általános } \\
\text { képzésben } \\
\text { (óra) }^{*}\end{array}$} & \multicolumn{2}{|c|}{$\begin{array}{l}\text { Osztálynagyság } \\
\text { (tanuló) }\end{array}$} & \multirow{2}{*}{$\begin{array}{c}\text { Átlagos } \\
\text { pedagógusbér } \\
15 \text { év } \\
\text { gyakorlattal, alsó } \\
\text { középfokon (ppp } \\
\text { USD) }\end{array}$} & \multirow[b]{2}{*}{$\begin{array}{l}\text { Matematika- } \\
\text { tesztpontszám } \\
\text { PISA } 2012\end{array}$} \\
\hline & & $\begin{array}{l}\text { Általános } \\
\text { iskola }\end{array}$ & $\begin{array}{c}\text { Alsó } \\
\text { középfok }\end{array}$ & & \\
\hline Korea & 712 & 25 & 33 & 50040 & 554 \\
\hline Japán & 807 & 28 & 33 & 47561 & 536 \\
\hline Hollandia & 960 & 23 & $\mathrm{~m}$ & 68064 & 523 \\
\hline Észtország & 715 & 17 & 16 & 12525 & 521 \\
\hline Finnország & 703 & 19 & 20 & 42601 & 519 \\
\hline Lengyelország & 693 & 18 & 22 & 20700 & 518 \\
\hline Belgium (fr) & 880 & 21 & $\mathrm{~m}$ & 46616 & 515 \\
\hline Németország & 785 & 21 & 24 & 67736 & 514 \\
\hline Ausztria & 803 & 18 & 21 & 46625 & 506 \\
\hline Ausztrália & 1012 & 24 & 24 & 52082 & 504 \\
\hline Írország & 922 & 24 & $\mathrm{~m}$ & 55148 & 501 \\
\hline Szlovénia & 699 & 19 & 20 & 32819 & 501 \\
\hline Dánia & 807 & 21 & 21 & 51122 & 500 \\
\hline Csehország & 764 & 20 & 21 & 19515 & 499 \\
\hline Franciaország & 920 & 23 & 25 & 37065 & 495 \\
\hline Anglia & 878 & 25 & 19 & 41393 & 494 \\
\hline Izland & 762 & 19 & 20 & 28742 & 493 \\
\hline Luxemburg & 898 & 16 & 19 & 105780 & 490 \\
\hline Portugália & 830 & 21 & 22 & 34694 & 487 \\
\hline Olaszország & 928 & 19 & 22 & 36577 & 485 \\
\hline Spanyolország & 897 & 21 & 24 & 45783 & 484 \\
\hline Szlovákia & 762 & 17 & 20 & 13365 & 482 \\
\hline USA & 982 & 21 & 27 & 47046 & 481 \\
\hline Magyarország & 663 & 21 & 21 & 13520 & 477 \\
\hline Izrael & 972 & 27 & 28 & 26912 & 466 \\
\hline Görögország & 784 & 17 & 22 & 26617 & 453 \\
\hline Törökország & 780 & 24 & 28 & 27607 & 448 \\
\hline Chile & 1052 & 30 & 31 & 24725 & 423 \\
\hline Mexikó & 922 & 20 & 27 & 26229 & 413 \\
\hline OECD-átlag & 836 & 21 & 24 & 40570 & 494 \\
\hline
\end{tabular}

* A szerző számítása (általános képzés összes órája/általános képzés hossza, ami Magyarország esetében 8 év)

Forrás: Education at a Glance 2014, OECD 
2. táblázat. Néhány ország hatékonysági indexe a pedagógusbérek, osztályméret és PISA matematikateljesítmény alapján, 2012

\begin{tabular}{|c|c|c|c|}
\hline Sorszám & Ország & Hatékonysági index (\%) & $\begin{array}{c}\text { PISA-rangsor } \\
\text { (2012 matematika) }\end{array}$ \\
\hline 1 & Finnország & 87,81 & 5 \\
\hline 2 & Korea & 86,66 & 1 \\
\hline 3 & Csehország & 84,38 & 14 \\
\hline 4 & Magyarország & 84,08 & 24 \\
\hline 5 & Japán & 83,88 & 2 \\
\hline 6 & Új-Zéland & 83,30 & 12 \\
\hline 7 & Szlovénia & 83,28 & 10 \\
\hline 8 & Ausztrália & 81,23 & $\mathrm{~s}$ \\
\hline 9 & Svédország & 80,58 & 23 \\
\hline 10 & Izland & 79,39 & 17 \\
\hline 11 & Egyesült Királyság & 78,71 & 16 \\
\hline 12 & Franciaország & 78,69 & 15 \\
\hline 13 & Izrael & 77,84 & 25 \\
\hline 14 & Hollandia & 76,80 & 4 \\
\hline 15 & Írország & 76,80 & 11 \\
\hline 16 & Ausztria & 74,68 & 8 \\
\hline 17 & Norvégia & 74,05 & 18 \\
\hline 18 & Belgium & 73,52 & 6 \\
\hline 19 & Egyesült Államok & 72,66 & 22 \\
\hline 20 & \begin{tabular}{|l|} 
Chile \\
\end{tabular} & 72,54 & 28 \\
\hline 21 & Törökország & 71,44 & 27 \\
\hline 22 & Dánia & 70,60 & 13 \\
\hline 23 & Olaszország & 69,81 & 20 \\
\hline 24 & Portugália & 68,29 & 10 \\
\hline 25 & Németország & 67,01 & 7 \\
\hline 26 & Spanyolország & 63,09 & 21 \\
\hline 27 & Görögország & 60,64 & 26 \\
\hline 28 & Svájc & 59,71 & 3 \\
\hline 29 & Indonézia & 51,13 & 30 \\
\hline 30 & Brazília & 25,45 & 29 \\
\hline
\end{tabular}

Forrás: Efficiency index, 2014

Magyarország negyedik helyezése meglepőnek túnhet, de ezt az előkelő helyezést éppen azzal érjük el, hogy az oktatásra jóval az átlag alatt költünk, és ehhez képest érünk el jobb eredményt. Ahogy a jelentés is fogalmaz: „Magyarország és Svájc 
jó példája a választási lehetőségnek [vagyis annak, hogy valaki a hatékonyságra vagy a minőségre (magasabb teljesítményre) szavaz - a szerző]: Magyarország jól teljesít a hatékonysági indexen, de rosszul, amikor az eredményességet nézzük. Svájc éppen az ellenkezője - a PISA eredménye egyike a legjobbaknak, de mivel arányaiban sokat költ az oktatásra, a hatékonysági indexen rosszul teljesít." (Efficiency index: 17)

A hatékonysági indexet létrehozók az eredményesség és hatékonyság dimenzióiban elért teljesítményük alapján öt országcsoportot különböztetnek meg (Efficiency index: 26):

- Elit teljesítők: (Finnország, Japán és Korea) - egyaránt magas szinten eredményesek és hatékonyak.

- Eredményesek és hatékonyak (Ausztrália, Csehország, ÚjZéland, Szlovénia) - viszonylag mindkét dimenzióban jól teljesítenek.

- Eredményesebbek, mint amilyen hatékonyak (Ausztria, Belgium, Dánia, Németország, Írország, Olaszország, Hollandia, Portugália, Spanyolország, Svájc) - ezeknek az országoknak az oktatás minősége a prioritás, ezért hajlandóak az átlagosnál többet költeni rá.

- Hatékonyabbak, mint amilyen eredményesek (Franciaország, Magyarország, Izland, Izrael, Norvégia, Svédország, Egyesült Királyság, USA) - ezek az országok nagyobb súlyt fektetnek a hatékonyságra, mint a minőségre, ezért hajlamosak alulfinanszírozni az oktatásukat. ${ }^{4}$

- Se nem hatékonyak, se nem eredményesek (Brazília, Chile, Görögország, Indonézia, Törökország) - ezek az országok nem használják hatékonyan az erőforrásaikat.

\section{A legfontosabb erőforrás-tényező - a pedagógus}

A hatékonysági index szerzői érdekes kísérletet is tesznek arra, hogy milyen irányba kellene a ráfordításokat alakítani egy-egy országnak, hogy a finn szintet elérjék. Magyarország esetében vagy a bérek több mint megkétszerezését vagy az egy pedagógusra jutó tanulók számának a 12 föről 3 före való leszállítását javasolják. Nyilvánvaló, hogy ezek a javaslatok kevéssé 
életszerǔek, de nem pusztán a nagyobb költségek miatt. A kiscsoportos foglalkozások előnyeit mindenki ismeri, de nem tudunk semmit a konkrét pedagógusi erőfeszítésekről, a tanári munka minőségéről. Ha a tanárok visszatartják a teljesítményüket, akkor a nagyobb pedagógusi létszám nem takar annyi energiaberuházást, mint elsőre gondolnánk. A kevesebb, de jól megfizetett tanár vagy a sok, de kevésbé megfizetett pedagógus közé nem tehetünk egyenlőségjelet. Magyarországon korábban egy olyan ördögi kör alakul ki, ahol a gyereklétszámra vetített túlzottan nagy pedagóguslétszám nem tette lehetővé a bérek emelkedését, az alacsony bérek viszont nem tették vonzóvá a pedagóguspályát, ezért azon az évek során egyre erősebb kontraszelekció működött (Varga, 2007). A nem eléggé vonzó béreknek is a következménye, hogy a pedagógusok közt egyre kevesebb a fiatal, és bizonyos szakmaterületeken hatalmas hiány látszik felhalmozódni (természettudomány, informatika, idegen nyelv). Az általános szintű, teljesítményhez nem kötött béremelések hatását vizsgáló egyes szimulációk azt mutatják, hogy a béremelés elsősorban a középfokú főiskolai végzettségű nőtanárok keresetében jelentett valódi javulást a piaci bérekhez viszonyítva, a magasan kvalifikált férfiak esetében a közszférán kívül található keresetek még mindig sokkal magasabbak, ezért ezek a béremelések sem tették sokkal vonzóbbá a pályát a fiatal egyetemi végzettségű férfiak számára (Varga, 2013). A pedagógus-életpályamodell sok országban azt a célt szolgálja, hogy a teljesítményhez valamilyen módon köthető olyan bérezési rendszer alakuljon ki, amely a jó képességű fiatalokat a pályára vonzza, de ezek a rendszerek csak hosszú távon tudják kifejteni a hatásukat. Egyaránt kedvezőtlen, ha nem eléggé vonzó béreket ajánlanak fel ${ }^{5}$ vagy nem elég vonzó a belépők számára ${ }^{6}$. A minőségi pedagógus szerepét nagyon sok irodalom hangsúlyozza (Teachers matter, 2005; McKinsey, 2007), de a minőségi pedagógus tömeges megjelenése több tényező bonyolult együttesétől függ. Önmagában a béremelés még nem fogja megemelni a pedagógusok minőségét, a pedagógusképzés és -továbbképzés, a pedagógust segítő személyzet és szolgáltatások, a megfelelő szakmai autonómia szintje egyaránt fontos tényezők. 


\section{Eredményesség és méltányosság}

Sokszor a hatékonyság/eredményesség fogalma összekapcsolódik a piac és a verseny fogalmával. Megfelelő információk birtokában elvileg a szülők és a tanulók megalapozott ítéletet hozhatnának az egymással versengő iskolák szolgáltatásairól, a leghatékonyabb iskolák pedig magukhoz vonzzák a legjobb diákokat és erőforrásokat, míg a többiek lecsúsznak. Ez a fajta verseny természetesen a közoktatás terén lehetetlen, hiszen ellátási kötelezettség van egy megadott szinten. Ugyanakkor, amennyiben az intézmények megtehetik, mert a kliens számára (akár az egészségügyben vagy a biztosítópiacon) sokszor nem adott a valóban szabad választás lehetősége (területi szempontok, tökéletlen információ), kizárják az ügyfeleik közül a magas költséggel (erőfeszítéssel) járó magas kockázatú klienseket. Ezzel egy olyan szelekció indul be, ahol kialakulnak az egymástól igen különböző homogén iskolák és felerősödhet a szegregáció. A piaci mechanizmusoknak szabad utat engedő oktatási rendszerek eredményessége a PISA-adatok alapján nem javult, habár „hatékonyabb” (mert olcsóbb) lett a működésük.

A nemzetközi szakirodalomban - a minőség vagy eredményesség (excellence) és az egyenlőség vagy méltányosság (equity) már régóta együtt tételeződő fogalompárt alkotnak. A PISA-adatok is arról árulkodnak, hogy a méltányosabb rendszerekben a tanulók általában magasabb szinten teljesítenek, viszont az erősen szelektív rendszerekben az össztanulói teljesítmény elmarad a nemzetközi átlagtól. Ez arra utal, hogy a méltányosság és eredményesség (ami a PISA-vizsgálat esetén, egy bizonyos módon mért tanulói teljesítményt jelent) - a rendszer szintjén mindenképpen - két egymást segítő dimenzió, de legalábbis egyáltalán nem egymást kizáró tényezők (lásd 4. ábra). 
4. ábra. A matematikaeredmény és a családi háttér hatásának összefüggése, PISA, 2012 (forrás: Balázsi és mtsai, 2013)

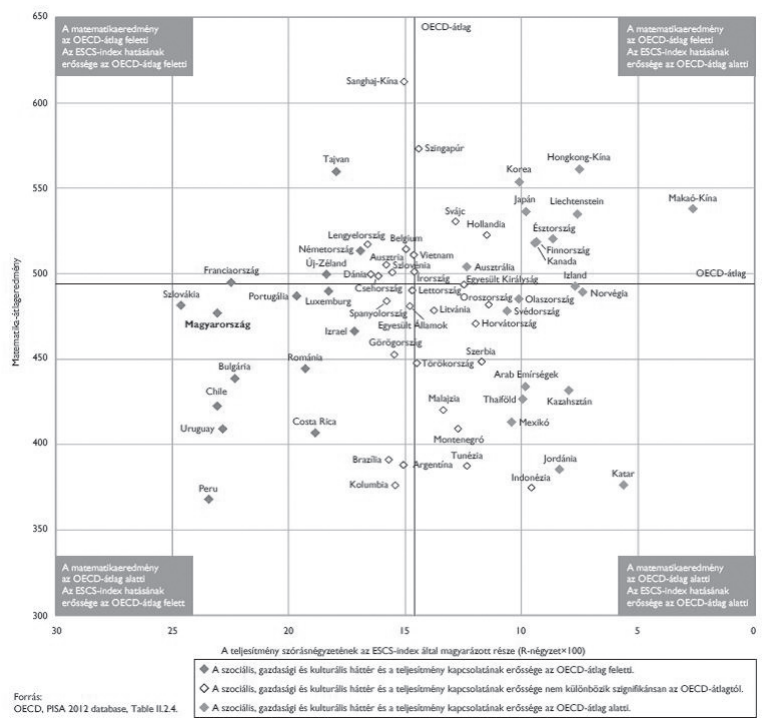

A 4. ábrán a függőleges tengely jelzi az eredményességet (excellence), vagyis a PISA 2012 nemzetközi vizsgálatban elért matematikateljesítményt (500 pont az átlag), a vízszintes tengely pedig az oktatás méltányosságát (equity) mutatja, azt, hogy mennyire határozza meg a családi háttér a teljesítménybeli szórást a tanulók közt. Minél inkább meghatározó a családi háttér a tanulók közötti teljesítménybeli különbségben, annál inkább bal oldalon helyezkedik el egy adott ország és annál kevésbé tekinthető méltányosnak. Nem véletlen, hogy ezen a térfélen azok az országok találhatók, amelyek iskolarendszere igen szelektívnek mondható, az iskolarendszer múködése pedig nem független a társadalom és a pedagógus múködésétől. Minél hierarchikusabb és rendiesebb egy társadalom, annál inkább hajlamos az elit az iskolapolitikát úgy alakítani, hogy kedvező társadalmi pozícióját minél nagyobb eséllyel biztosítsa, vagyis a családi státus quo szerepét erősítsék. Ez az a folyamat, ahol az iskola, akarva-akaratlanul ludas, hiszen a ha- 
mis pedagógiai érvekkel alátámasztott szelekció7 folytán olyan homogén tanulási közegek alakulnak ki, ahol a társadalmi tőke gyarapításának esélye is igen egyenlőtlenül oszlik meg, s ez egyben azt is jelenti, hogy az oktatási rendszer nem aknázza ki a tanulóiban rejlő lehetőségeket.

\section{Az eredményességet és méltányosságot együtte- sen mérő mutatók (reziliencia, hozzáadott érték)}

A nemzetközi mérésekben a méltányosság egyik alapindikátoraként használják a reziliens tanulók arányszámát, ahol azt mérik, hogy a tanuló képes-e a családi háttérhez képest elmozdulni, vagyis a $\mathrm{CSHI}^{8}$ alsó negyedébe eső diákok hány százaléka tud - a teljesítményük szerint - a felső negyedbe kerülni. A 2012-es PISA felmérés alapján, Magyarországon 4,1 százalék a reziliens diákok aránya, és ez szignifikánsan elmarad az OECDországok 6,4 százalékos átlagától. Jól látható, hogy az eredményesebb országokban jellemző a reziliens tanulók relatív magas aránya (pl. Korea, Japán, Svájc, Észtország, Finnország - lásd 5. ábra).

Az Országos kompetenciamérés 2010-tól tanulói szinten összekapcsolható adatokat tartalmaz, ezzel megnyitva a lehetőséget a valódi, longitudinálisan mért pedagógiai hozzáadott érték előállításához, amely az egyén fejlődését úgy mutatja, hogy közben kontroll alatt tarthatók a családi háttérváltozók. A legutolsó elérhető jelentés szerint a magyar oktatási rendszerben a 6 . és 8 . évfolyam között nagyobb mértékű a növekedés, mint a 8. és 10. évfolyam között. A matematika területén ezt azzal magyarázzák, hogy „a gyakorlati alkalmazási készségek fejlesztésére a középiskolai matematikaoktatás általánosságban kevés hangsúlyt helyez." (Balázsi és mtsai, 2014) 
5. ábra. Reziliens tanulók aránya, PISA, 2012 (forrás: PISA 2012, OECD)

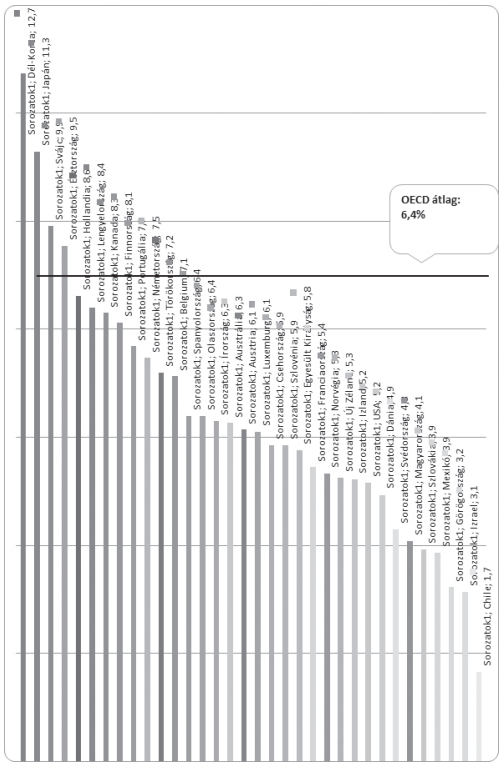

\section{Az eredményességet befolyásoló kontextuális tényezők}

Láthattuk, hogy önmagában a több ráfordítás még nem hoz feltétlenül nagyobb eredményességet, nem mindegy ugyanis, hogy az oktatásra fordított pénzeket mikor, mire és hogyan költjük el. Az eredményességet, illetve a befektetések hasznosulását ugyanis számos egyéb, kontextuális, strukturális, illetve kulturális tényező is befolyásolja. A PISA felméréssel szemben is hallani olyan kritikai hangokat, amelyek szerint nem lehet az oktatási eredményességet egy globálisan érvényes dimenzióra kifeszíteni, az országok közötti kulturális különbségek gyakran ezt keresztbe metszik (Lannert, 2015). 


\section{Korai beavatkozás}

A legújabb pszichológiai kutatások aláhúzzák, hogy a legfontosabb kompetenciák a korai években fejlődnek a legdinamikusabban (Bronfenbrenner és Morris, 2006). A társas kapcsolati készségek egy- és kétéves kor között fejlődnek nagyot, és utána az agy érzékenysége ezen a területen folyamatosan csökken, és négyéves korra közepes szintre áll be. A nyelv fejlődése terén az agy szintén az egy- és kétéves kor között dolgozik a legintenzívebben, a számolási készségek terén pedig az egy- és hároméves kor közötti korszak döntő (OECD, 2012).

Az oktatásba fektetett összeg megtérülési rátája James Heckmann, Nobel-díjas közgazdász megfigyelése szerint idővel csökken (vagyis az a kisgyermekkori szakaszban a legmagasabb), a csökkenés pedig kifejezetten meredek a kedvezőtlen gazdasági társadalmi háttérrel rendelkező gyerekek esetén (lásd 6. ábra). Ez utóbbi azt jelenti, hogy a kora gyermekkori beruházás megtérülési rátája a hátrányosabb helyzetű gyermekek esetében különösen magas. Ez a közösségi források felhasználását tekintve intő jel, azt jelenti, hogy az adóforintokat, adóeurókat legjobban a korai szakaszban tudja elkölteni az állam. Ez ugyanakkor nem jelenti azt, hogy komplett intézményrendszereket kellene így finanszírozni. Ezek helyett azokat a lehetőségeket, formákat kell támogatni, amelyek segítségével a gyerekek már a korai életszakaszban kellőképpen felvérteződnek azokkal a kompetenciákkal, amelyekre a későbbi boldogulásukhoz szükségük van. Ez hosszú távú szemléletet igényel, hiszen a kora gyermekkori beruházások haszna 20-30 évvel később lesz igazán látható.

A longitudinális mintákon alapuló elemzések egységes tanulsága, hogy a kognitív képességekhez viszonyítva igen erős kapcsolat van a nem kognitiv képességek és a későbbi munka-erőpiaci sikerek között, vagyis a munkaerő-piaci sikert nem lehet leszúkíteni pusztán a kognitív folyamatokra (Surányi, 2008). Erre maga James Heckmann is felhívja a figyelmet, amikor a hatékony kora gyermekkori fejlesztésről ír. Az Egyesült Királyság kora gyermekkori programjainak értékelése során az alábbi fő megállapításokat teszi. 
6. ábra. Megtérülés az oktatás különböző szintjein (Efficiency, 2008; Cunha és mtsai, 2006)

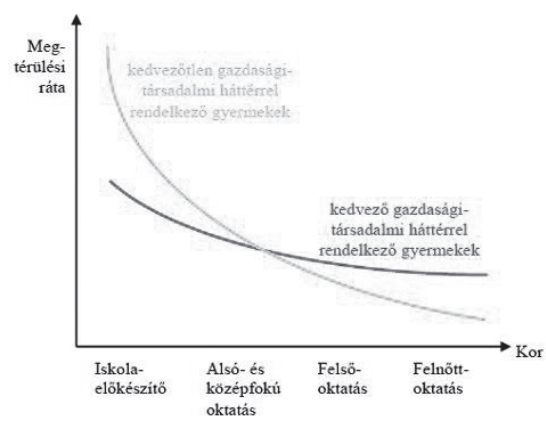

- A kora gyermekkori beavatkozás annál hatékonyabb, minél hamarabb történik.

- A kora gyermekkori programok elsősorban a nem kognitív képességeket fejlesztik, éppen ezért ennek jelentőségét a közgazdasági és szociális kérdésekkel foglalkozó szakemberek gyakran alulbecslik.

- A kora gyermekkori programokat elsősorban a hátrányos helyzetú rétegek esetében kell támogatni. A programok lehetnek univerzálisak, de költségvetési támogatást csak a szülői minőséget tekintve legrászorultabbak esetében célszerű nyújtani.

- A kora gyermekkori programoknak nemcsak állami programoknak kell lennie, a nem kormányzati szereplőknek is teret kell adni (Heckmann, 2011).

Heckmann szerint az amerikai társadalom egyre polarizáltabb, és miközben tesztekkel mérik a kognitiv képességeket és teljesítményt, nem vesznek tudomást a fizikai és mentális egészségről, motivációról, szociális, érzelmi képességekről, a kitartásról, figyelemről, önbizalomról (Heckmann, 2008). Holott az egyik legrégebbi amerikai kora gyermekkori ún. Perry program értékelése megmutatta, hogy ezeken a területeken tudnak igazán hatékony javulást elérni. A programban 1962 és 1967 között 30 héten át napi két és fél óra foglalkozást és heti 
másfél órás családlátogatást nyújtottak hátrányos helyzetű gyerekeknek. A kutatók a résztvevőket 40 éves korukig nyomon követték és a kontrollcsoporthoz képest 6-10 százalékos megtérülést mutattak ki. Habár a program a résztvevők IQ-jára nem volt tartós hatással, a nem kognitív készségek esetén tartós javulás volt tapasztalható és ez az, ami a résztvevőket sikeressé tette felnőttként (Heckmann, 2011).

A korai beavatkozás közgazdasági értelemben is megtérülést hozó logikája a következő: A korai tanulás értékessé teszi az elsajátított készségeket és felkelti a motivációt a még több tanulásra. A korai szakaszban elsajátított kognitív, szociális és érzelmi kompetenciák ráadásul a későbbi tanulást is hatékonyabbá és könnyebbé teszik, és növelik az esélyét, hogy a tanulási tevékenység ne szűnjön meg idejekorán, hanem éppen ellenkezóleg, az - a ma divatos szóhasználattal élve - egy életen át tartson. A korai beavatkozás a későbbi beruházások költségeit is csökkenti. A munkaerő-piaci képzések, felnőttek írás-olvasni tanítása, a börtönben nyújtott rehabilitációs programok jóval kisebb megtérüléssel járnak, mint a kora gyermekkori beavatkozások, amelyek - ez fontos - a szülői nevelés minőségén hivatottak javítani. A már említett Perry programban a rendszeres családlátogatásnak pozitív hatása volt a szülők életére, és segített megváltoztatni a gyermek kedvezőtlen otthoni környezetét.

\section{A szegénység hatása}

Ugyancsak friss kutatási eredmény, hogy a nyomor akadályozza a kognitív funkciók fejlődését, mert a szegénységből fakadó folyamatos erőfeszítések, aggodalmak felemésztik a mentális kognitív kapacitásokat, így nem marad belőle más feladatokra (Mani és mtsai, 2013). A roma fiatalok lemaradása is szinte teljes mértékben a szegénységre, a szülők iskolázatlanságára és a munkapiacról való kiszorulásukra, valamint az ebből fakadó hátrányokra vezethetőek vissza (Kertesi és Kézdi, 2011). Mindez arra figyelmeztet, hogy amennyiben a magyar gyermekek nagy hányada szegénységben él már kora gyermekkorától kezdve és a szociális ellátórendszer és a kora gyermekkori nevelés rendszere nem tudja a káros hatásokat ellensúlyozni, 
úgy ezek a gyerekek olyan hátrányokkal indulnak a közoktatásban, amit az iskolarendszer már nem tud orvosolni.

\section{A megfelelö szakmapolitika}

A másik faktor, ami befolyásolhatja a rendszer eredményességét, a jó színvonalú, tényekre alapozó gyermekközpontú szakmapolitika. Nemzetközi és hazai kutatási eredmények azt támasztják alá, hogy a tanulók motiváltsága alapvető ahhoz, hogy jól tanuljanak, ehhez viszont gyermekközpontú pedagógiára lenne szükség. A PISA-adatokra épülő elemzések ${ }^{9}$ azt bizonyítják, hogy a méltányos iskolarendszerek hatékonyabbak, mint a szelektívek, az autonóm iskolák jobban múködnek, mint a centralizáltak. A legfrissebb PISA-adatokat elemző tanulmány szerint a magyar gyerekek a nemzetközi átlagnál kevesebbet hiányoznak az iskolából, több leckét írnak, többet magolnak, viszont kevesebb eredményt érnek el (Csüllög, Molnár és Lannert, 2014). A környező országokkal összevetve, az elemzést azt mutatja, hogy a Magyarországon a zsúfolt tananyag és az egy tantárgyra jutó alacsony óraszám, valamint az egész napos kötelező benntartózkodás együttesen azt eredményezi, hogy a fiatalok számára a tanulás az örömtelen, fárasztó és időigényes magolást jelenti. Ennek is betudható, hogy nem eredményesek, ugyanis nincs kellő idő és türelem a gondolkodás és a kreativitás fejlesztésére.

A PISA-adatbázis elemzésével a digitális szövegértés romlása mögött lévő okokat is fel lehet fedni. Az egyik legmeghökkentőbb eredményt, miszerint az iskolában számítógéppel töltött idő negatív kapcsolatban áll a digitális szövegértéssel, már a korábbi felmérések is kimutatták (PISA, 2011: 186). Sőt, az is tudható, hogy az otthoni számítógépezéssel töltött idő viszont éppen hogy pozitívan korrelál a digitális szövegértéssel, még akkor is, ha a családi háttérrel kontrollálnak (PISA, 2011:178). Az iskolai számítógép-használat negatív hatását a szakértők abban látják, hogy a tanórai irányított környezetben a tanuló kevéssé fejlődik, mint egy olyan környezetben, ahol saját tempója szerint és bátran hibázva, kísérletezve haladhat előre. A fiatalok ugyanis aktívan, saját maguk által vezérelve és a kortársakkal együtt tanulnak igazán, általában nem iskolai és 
főleg nem „iskolás” környezetben. Mindebből az következik, hogy a fejlesztéseknek - az iskolai számítógép-beruházások és tankönyvgyártás helyett - az otthoni tanulást kellene infokommunikációs technológiával segítenie és a pedagógusokat az infokommunikációs eszközök kreatív használatára felkészítenie.

\section{A pedagógusok módszertani kultúrája}

A legfontosabb mikroszinten ható faktor a pedagógus maga. Téves az a feltételezés, hogy az iskolának alig van hatása, hiszen a média és a kortársak erősebben hatnak a tanulókra, mint ahogy az is, hogy a tehetség magától is kifejlődik, nincs szükség a pedagógus segítségére. ${ }^{10} \mathrm{~A}$ pedagógus hatása meglehetősen jelentős. Rosenthal és Jacobson híres tanulmánya, a Pygmalion az osztályteremben nyomán számos alkalommal megismételték a kísérletet, amely során véletlenszerűen kiválasztott tanulókról hitették el a pedagógusokkal, hogy nagyobb intellektuális teljesítményre képesek. A tanév végére azok a tanulók, akikről ezt feltételezték, hogy jobban fejlődtek (átlagosan 12 IQ ponttal teljesítettek jobban), mint a kontrollcsoport tagjai (Rosenthal és Jacobson, 1968). A szakirodalom Pygmalion-hatásnak hívja, amikor a pedagógus azokból a tanulókból, akiktől sokat vár el, többet hoz ki, mint azokból, akiktől nem vár el sokat, függetlenül a tanuló valós képességeitől. A Pygmalion-hatás a pedagógusi értékelés önbeteljesítő hatását mutatja. ${ }^{11}$ Ugyanakkor téves az a feltételezés, hogy a pedagógus csak pozitiv irányban tudna hatni. A Pygmalion-hatás ellentettje az ún. Gólem-hatás, amikor a pedagógus a felületes benyomás alapján rögtön beskatulyázza a tanulót és alacsony elvárásaival - önbeteljesítő próféciaként - alacsonyabb szintű parkolópályára tereli (Rosenthal és Jacobson, 1968; Rosenthal, 1987, 1991). Fontos, hogy a Pygmalion- vagy Gólem-hatás esetén a pedagógus nem valós teljesítmény alapján, hanem egyéb jellemzők alapján ítél. Ez a hatás valójában nem direkt módon múködik, hiszen a tanár szándékától független: a nem verbális viselkedésén át közvetíti az elvárásait a tanuló felé (Rosenthal, 1997).

Nemcsak az a fontos azonban, hogy a pedagógus a tanuló valós teljesítménye alapján ítéljen, hanem az is, hogy reflek- 
táljon a változásokra. Az önmagukat fenntartó, visszaigazoló elvárások hatásairól először Cooper és Good írtak (Cooper és Good, 1983). Ennek lényege, hogy a pedagógus - a tanuló korábbi teljesítményére alapozva - a kezdeti elvárásoknak megfelelően alakítja ki a nevelési környezetet, nem figyelve a tanuló adott jelzéseire, teljesítményére. Így ha a tanuló a portfóliója alapján átlagosnak mondható, hiába old meg majd feladatokat gyorsabban, a pedagógus továbbra is egy átlagos tanulónak kijáró környezetet és elvárást állít fel, konzerválva a tanulót az adott szintjére.

Hogyan múködik mindez a valóságban? Azokat a tanulókat, akiktől többet várnak el, a magasabb teljesítmény esetén dicsérik meg, míg azok esetében, ahol nem várnak el ilyen sokat, ott azzal is megelégednek a pedagógusok, ha nem olyan magas a teljesítményük, de nem is dicsérik olyan sokat őket (Rubie-Davies, 2010). A gyengébbnek tartott tanulók esetében a pedagógus nem várja ki a tanuló válaszát és többet lép interakcióba a jobbnak ítélt tanulóval (ez a tipikus pedagógusi kudarckerülő magatartás). Azokban az osztályokban, ahol a pedagógus magas elvárásokat támaszt, a gyerekek többet fejlődnek, és az önértékelésük és ezzel együtt a teljesítményük is javul. Az elvárások alacsony szintje (ami mögött gyakran a rossz értelemben vett differenciálás rejlik, amikor a pedagógus látszólag alkalmazkodva a tanuló igényeihez nem a tanítási módszert változtatja meg, hanem leszállítja az elvárás szintjét, hogy így olcsó sikerélményhez juttassa a gyereket és saját magát) viszont egy negatív spirált indít el. Ha egy tanuló folyamatosan alulteljesít, illetve soha nem várnak el tőle sokat, akkor egy idő után azt gondolja, hogy ő sohasem tudja megoldani a feladatokat és kialakul egy ún. tanult tehetetlenség (helplessness), amikor már anélkül feladja, hogy bármilyen kísérletet tenne a megoldásra.

A kompetenciamérés adatai azt mutatják, hogy az általános iskola után a középfokon nagyon eltérően fejlődnek a tanulók: míg a gimnáziumokban töretlen a fejlődés, a szakiskolákban még visszalépés is tapasztalható. Úgy tűnik, hogy Magyarországon az általános iskolában múködik a Pygmalion- és Gólem-hatás (akitől sokat várnak el, jól teljesít, akitől keveset, az lemarad), majd amikor a tanulók már bekerülnek a közép- 
fokú intézménybe, múködésbe indul az önigazoló, önmagukat fenntartó elvárások mechanizmusa. Ez utóbbi magyarázza azt a paradox jelenséget is, miért fejlődnek vissza a szakiskolások szövegértési kompetenciái 10. évfolyamra. Ebbe az iskolatípusba ugyanis a gyenge eredményekkel rendelkező tanulók kerülnek, akik számára a pedagógusok már az első perctől ennek az alacsony teljesítményszintnek „megfelelő” és így egyben konzerváló tanulási környezetet alakítanak ki. Valószínúleg a pedagógusok elfogult félreértékelése és rossz értelemben vett differenciálása (vagyis, hogy nem a módszerben, hanem a tanulók iránti elvárásaikban differenciálnak és szállítják le így az elvárásaikat a szerintük gyenge tanulók esetén) lehet a fundamentuma a magyar oktatási rendszer legnagyobb búnének, annak, hogy nemhogy nem kiegyenlíti, de még fel is erősíti a családi háttér hatását. Ez lehet a háttere annak, hogy miért nálunk magyarázza a világon már egy évtizede a legnagyobb mértékben a családi háttér a tanulói eredményeket (Balázsi mtsai, 2013), és miért ilyen alacsony a reziliens tanulók aránya. Ebből a körből kitörni nem elég az osztályméreten változtatni vagy a pedagógusi fizetéseket emelni, hanem elsősorban a legjobbakat kell a pályára vonzani, megfelelő minőségű képzést nyújtani számukra és később pedig professzionális támogató hátteret biztosítani a munkájukhoz.

\section{Intézményi eredményesség, az eredményesség és az iskola}

Az eredményesség nemcsak rendszer-, de az intézmény szintjén is értelmezhető. Az iskola hatását a tanulók eredményességére a korai kutatások alábecsülték. Coleman 1966-os híres jelentése azt a későbbiekben is sokszor hangoztatott összefüggést erősítette meg, hogy a tanulók családi háttere, egyéni képessége határozza meg szinte teljes mértékben azt, hogy milyen eredményes lesz majd azok iskolai karrierje (Coleman, 1966). Azóta az ilyen természetű felmérések módszertana sokat finomodott, és bebizonyosodott, hogy az iskola hatása azért tûnt elhanyagolhatónak, mert nem mérték és elemezték kellő módon. A legújabb kutatások egyszerre nézik az egyé- 
ni szintet (tanuló teljesítménye), az osztálytermi folyamatokat (tanár-diák viszony) és az iskolában uralkodó intézményi légkört (a vezetés szerepe). Az új kutatások eredményei azt mutatják, hogy a tanulók teljesítményére a családi és egyéni hatáson túl erőteljesen hat az, hogy mi történik az osztályteremben, valamint az, hogy milyen az iskolavezetés kultúrája (lásd 7. ábra).

\section{7. ábra. Az iskolai eredményesség hatásmodellje}

(forrás: Creemers, 1996)

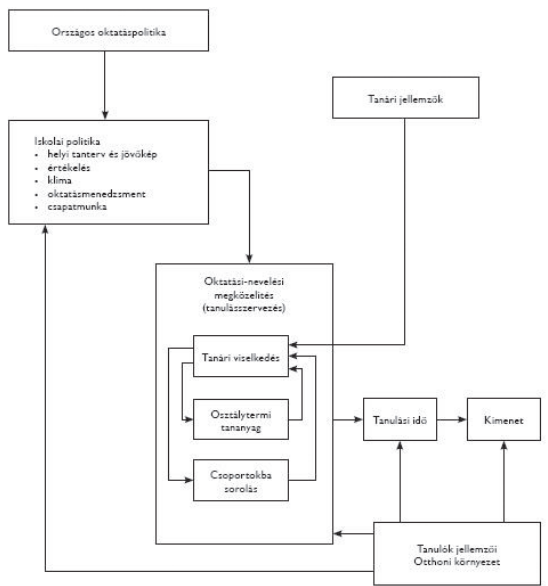

Egy másik megközelítés az osztálytermi eredményességet az elvont és fizikai értelemben vett megfelelő tanulói tér kialakításában látja, ahol a tanuló áll a középpontban, s így aktív formálója saját tanulásának (lásd 8. ábra). 
8. ábra. A megfelelö tanulói tér jellemzői (forrás: Creative agent project)

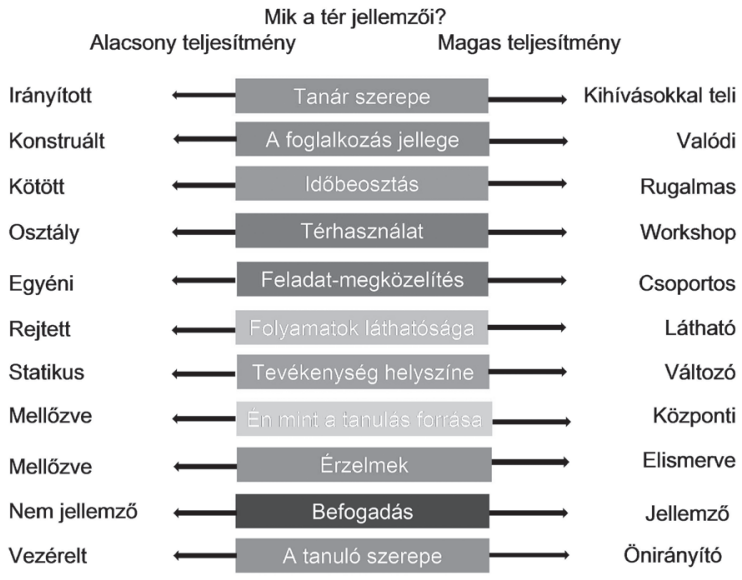

A magyarországi oktatási intézmények eredményességéről ma elsősorban az Országos kompetenciamérés telephelyi jelentésein át tájékozódhatunk. ${ }^{12} \mathrm{~A}$ középiskolák eredményességét bemutató kötetek viszont ma már nem jelennek meg, a legutolsót 2006-ban publikálták. ${ }^{13}$ Mind a mai napig szerencsésen elkerülte Magyarország azt a csapdát, hogy a tanulói kompetenciamérések alapján, direkt módon megítéljék és jutalmazzák vagy szankcionálják egy intézmény teljesítményét. A nemzetközi példák azt mutatják, hogy a tesztek mindenhatósága arra ösztönzi a pedagógusokat, hogy tesztekre tanítsanak, és azok eredményét minél erőteljesebben - és nem feltétlenül korrekt módon - befolyásolják. ${ }^{14}$ Mindez viszont megöli a mérés eredeti célját, hogy segítse a pedagógust abban, hogy valóban hosszú távon is eredményes legyen a tanítási és tanulási tevékenység. Érdemes elkerülni ezeket a csapdákat. Amennyiben nincs konszenzus arról, hogy mit tekintünk eredményesnek, akkor bármilyen mérőeszköz és indikátor ilyen értelemben vett használata önkényesnek tünhet. Veszélyes lehet az is, ha az eredményességmérés adatai 
alapján az iskolákat beskatulyázzák, és ez alapján jutalmazzák vagy büntetik őket a finanszírozási eszközök segítségével. Az eredményességről szóló információknak nem az iskola elszámoltathatóságát kell elsősorban szolgálnia, hanem az iskola és a tanári közösségek fejlesztését. Ehhez viszont fontos, hogy konszenzus alakuljon ki arról, hogy mit és hogyan mérünk, valamint az, hogy az eredményeket elsősorban fejlesztő célra használjuk fel. Ide viszont csak úgy juthatunk el, ha folyamatosan mérünk, az adatokat nyilvánosságra hozzuk és széles körű szakmai vitát folytatunk róla.

\section{Összegzés}

A közoktatás minősége egyaránt függ attól, hogy mennyire eredményes, méltányos és hatékony. A PISA-vizsgálatok azt mutatják, hogy általában a méltányos rendszerek eredményesebbek és egyben jól gazdálkodnak az erőforrásaikkal, tehát hatékonyak is. A nemzetközi mérések fontos tanulsága az is, hogy az alulfinanszírozottság nem kedvez az eredményességnek, de a több pénz nem jelent automatikusan jobb teljesítményt. Ahhoz, hogy jól gazdálkodjunk az erőforrásokkal (ami az oktatás esetében elsősorban a pedagógusokat jelenti), fontos, hogy az oktatás teljesítményét folyamatosan monitorozzuk és elemezzük. Ehhez ad segítséget az OECD háromévente történő PISA tanulói teljesítménymérése és az évente lefolytatott hazai Országos kompetenciamérés. A tények azt mutatják, hogy minél inkább a korai szakaszt finanszírozzuk, annál nagyobb a megtérülési ráta, illetve, hogy a pedagógusok módszertani kultúrája alapvetően meghatározza a közoktatás minőségét. Mindez felveti annak szükségességét, hogy az oktatás teljesítményét komplexen tudjuk mérni. Ehhez támpontot leginkább az olyan, a közoktatás minőségét komplexen mutató indikátorok, mint a hozzáadott érték (OKM) vagy a reziliens tanulók aránya (PISA) adhatnak. 


\section{Jegyzetek}

1 www.oecd.org/pisa

2 http://www.oecd.org/education/eag.htm

3 http://www.edefficiencyindex.com/

4 Ezek az országok többségében a piaci mechanizmusokat érvényesítik országaikban (lásd pl. amerikai charter iskola vagy a svédeknél felerősödő privatizáció), azt gondolva, hogy a piaci hatékonyság egyben eredményessé is teszi az oktatást. A finn modell sikerét viszont oktatáskutatók éppen abban látják, hogy magas szintű közösségi szolgáltatásként értelmezik az oktatást és nem a versennyel, hanem a pedagógusok képzettségével próbálják a minőséget emelni.

5 Ez történt az angol ún. Threshold rendszerben, ahol a béremelés nem volt olyan nagymértékű, hogy valódi hatást tudott volna kiváltani, ugyanakkor erőforrásokat vont el más, esetleg hatékonyabb fejlesztésektől.

6 A Zöld könyv (2008) ajánlata is az volt, hogy - ahogy a finneknél is tapasztalható - nem általános nagy béremelésre van szükség, hanem a kezdő bérek erőteljes megemelésére. Ugyanakkor ez sérti a már a pályán lévők érdekeit, így a stock és flow szemlélet szembemegy egymással és általában az egyéni (a bennlévő pedagógusok) érdekek győznek a közösségi (a legjobbak bevonzása magas kezdőbérrel) érdekekkel szemben.

7 Ezek a pedagógiai érvek az elkülönített tehetséggondozás és felzárkóztatás köntösében tulajdonképpen a differenciálásra képtelen pedagógus számára hoznak létre egy látszólag jobban kezelhető homogén közeget.

8 Családi háttérindex.

9 http://www.oecd.org/pisa/keyfindings/pisa-2012-results.htm

10 Az OFI egyik 2014-es pedagógusfelvételén a pedagógusok negyede nyilatkozta azt, hogy a tehetség magától kibontakozik.

11 Az önbeteljesítő prófécia hatásait a szociológiai szakirodalomban Robert Merton azonosította elöször (Merton, 1948).

12 http://www.oktatas.hu/kozneveles/meresek/kompetenciameres/eredmenyek

13 http://www.ofi.hu/tudastar/intezmenyi-szintu/kozepiskolaimunka

14 Ilyennek tekinthető az is, amikor egy intézmény az eredményességét nem a pedagógiai munka javításával, hanem a tanulói öszszetétel alakításával próbálja befolyásolni. 


\section{Irodalomjegyzék}

Balázsi Ildikó, Lak Ágnes Rozina, Szabó Vilmos, Szabó Lívia Dóra és Vadász Csaba (2014): Országos kompetenciamérés 2013. Országos jelentés. Oktatási Hivatal, Budapest.

Balázsi Ildikó, Ostorics László, Szalai Balázs, Szepesi Ildikó és Vadász Csaba (2013): PISA 2012: Összefoglaló jelentés. Oktatási Hivatal, Budapest.

Barber, M. és Mourshed, M.: (2007): How the world's best performing school systems come out on top. McKinsey \& Company.

Bronfenbrenner, U. és Morris, P. A. (2006): The bioecological model of human development. Handbook of Child Psychology, 1, 793-828.

Cooper, H. és Good, T. (1983). Pygmalion grows up: Studies in the expectations communication process. Longman, New York.

Coleman, J. és mtsai (1966): Equality of Educational Opportunity. Gorvernment Printing Office, Washington DC.

Creemers, B. P. M. (1996): School Effectiveness, Effective Instruction and School Improvement in the Netherlands. In: Reynolds, D. és Cuttance, P. (szerk.) School Effectiveness. Research, policy and practice. Cassell Wellington House, London.

Csüllög Krisztina, Molnár D. Éva és Lannert Judit (2014): A tanulók matematikai teljesítményét befolyásoló motívumok és stratégiák vizsgálata a 2003-as és 2012-es PISA mérésekben. In: Hatások és különbségek, Oktatási Hivatal, Budapest.

Education at a Glance (2014): OECD, Paris.

Heckmann, J. J. (2011): Effective Child Development Strategies. Prepared for the pre-K debates-current controversies and issues. Baltimore.

Heckmann, J. J. (2008): Schools, skills, and synapses. Economic Inquiry, Vol. 46, No. 3, July 289-324.

Kertesi Gábor és Kézdi Gábor (2011): The Roma/Non-Roma Test Score Gap in Hungary. American Economic Review, 101(3), 519-525.

Lannert Judit (2004): Minőség, hatékonyság, eredményesség. 
Új Pedagógiai Szemle, http://epa.oszk.hu/00000/00035/ 00087/2004-12-ko-Lannert-Hatekonysag.html (2015 07. 01.) Lannert Judit (2015): A PISA adatok használata és értelmezése a módszertani kritikák tükrében. Educatio, nyár.

Mani, A. és mtsai (2013): Poverty Impedes Cognitive Function, Science, 2013/8, 976-980.

Merton, R. K. (1948): The self-fulfilling prophecy. The Antiock Review, 8, 193-210.

Mourshed, M., Chijioke, Ch. és Barber, M. (2010): How the world's most improved school systems keep getting better. McKinsey \& Company.

OECD (2012): Starting Strong III: Early Childhood Education and Care. OECD, Paris.

PISA 2009 Results (2011): Students On Line. Digital Technologies and Performance (Volume VI), OECD, 177-180

Rosenthal, R. (1987): „Pygmalion” Effects: Existence, Magnitude, and Social Importance. Educational Researcher, December, 37-41.

Rosenthal, R. (1991): Teacher Expectancy Effects: A Brief Update 25 Years after the Pygmalion Experiment. Journal of Research in Education, September.

Rosenthal, R. (1997): Interpersonal Expectancy Effects: A Forty Year perspective. ERIC. Rosenthal, R. és Jacobson, L. (1968): Pygmalion in the Classroom. Holt, Rinehard and Winston, New York.

Rubie-Davies, C. (2010): Teacher expectation and perceptions of student attributes. Is there a relationship? British Journal of Educational Psychology, 80, 121-135.

Surányi Éva (2008): A gyermeki fejlődés hatása a felnőttkori munkaerö-piaci sikerességre. Háttértanulmány a Biztos Kezdet program hatásvizsgálatának kutatási koncepciójához. Kézirat

Teachers Matter (2005): Education and Training Policy, OECD. The Efficiency Index (2014): Dolton, P., Marcenaro-Gutiérrez, O. és Adam Still, A. Which education systems deliver the best value for money? GEMS Education Solutions, London.

Varga Júlia (2007): Kiből lesz ma tanár? A tanári pálya választásának empirikus elemzése. Közgazdasági Szemle, LIV, 609-662. 
Varga Júlia (2013): A közalkalmazotti béremelés hatása a pedagógusok pályaelhagyási döntéseire, Közgazdasági Szemle, LX, 579-600.

Fazekas Károly, Köllő János és Varga Júlia (2008, szerk.): Zöld könyv. A magyar közoktatás megújításáért. Ecostat, Budapest. 

Kötetünk tanulmányai a nevelésszociológia széles körét fogják át. A tudományág történetétől a jelen rendszerszintű és kisebb csoportokat érintő problémáinak feltárásáig elemzik az oktatás és nevelés folyamatát, ennek a folyamatnak az intézményeit, ágenseit. Mindezt azzal a szaktudással és szándékkal, hogy a ma felsőoktatásban tanulók, az oktatás gyakorlati problémáival később hivatásszerúen foglalkozók alapos ismereteket kapjanak ezekről a kérdésekről.

Forray R. Katalin

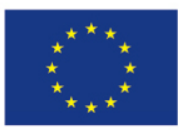

SZÉCHENYI 2020 